\title{
A EXCLUSÃO DE SÓCIOS NA SOCIEDADE LIMITADA DE ACORDO COM O CÓDIGO CIVIL DE 2002
}

\author{
Dissertação apresentada à Faculdade de \\ Direito da Universidade de São Paulo, sob a \\ orientação do Prof. Dr. Haroldo Malheiros \\ Duclerc Verçosa, como requisito parcial para a \\ obtenção do título de Mestre em Direito \\ Comercial.
}

FACULDADE DE DIREITO DA UNIVERSIDADE DE SÃO PAULO São Paulo 2008 



\section{AGRADECIMENTOS}

Ao Professor Haroldo Malheiros Duclerc Verçosa pela oportunidade e pela valiosa orientação. Aos Professores Marcos Paulo de Almeida Salles e Francisco Satiro de Souza Junior pelo precioso debate durante o exame de qualificação. Aos meus colegas - tantos, mas em especial Daniel, Joana e Juliana -, pelo inestimável apoio. A meus pais, minha irmã e Anna, por tudo. 


\section{ÍNDICE ANALÍTICO}

INTRODUÇÃO

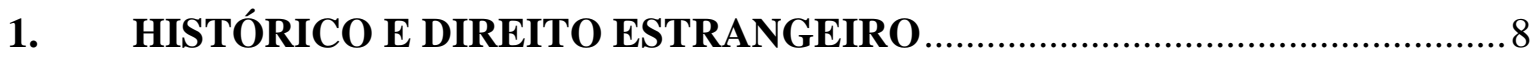

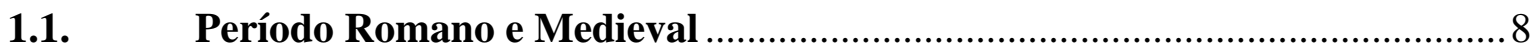

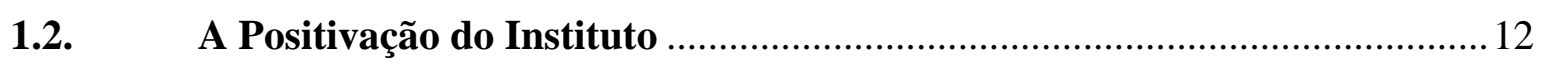

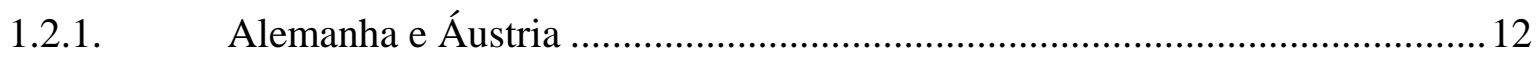

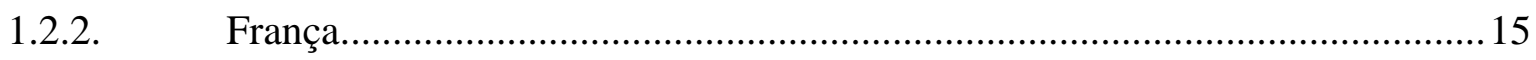

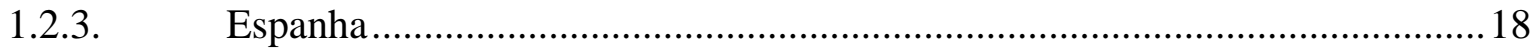

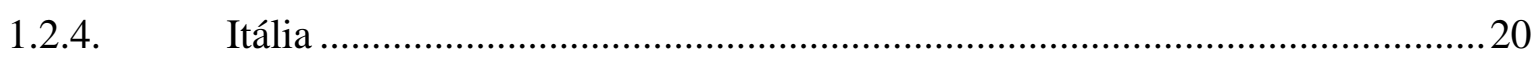

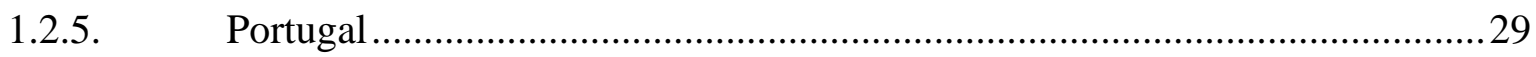

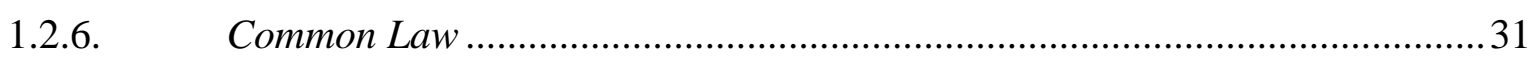

1.3. Desenvolvimento do Instituto no Brasil ...........................................................

2. FUNDAMENTO TELEOLÓGICO DA EXCLUSÃO DE SÓCIO.....................50

2.1. A Exclusão de Pleno Direito.......................................................................51

2.1.1. A Liquidação da Quota em Função de Dívida Particular do Sócio ..................51

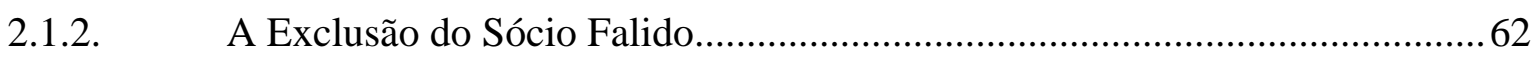

2.2. A Exclusão Facultativa .............................................................................68

2.2.1. Exclusão e Preservação da Empresa .................................................................68

2.2.2. Exclusão de Sócio e Propensão a Investir .......................................................72

2.2.3. O Sentido da Exclusão Extrajudicial de Sócio ....................................................75

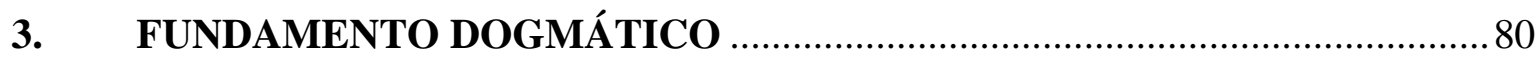

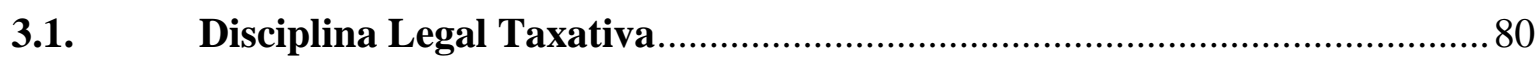

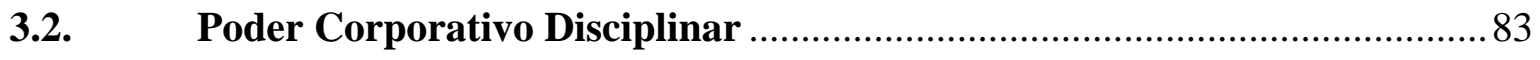

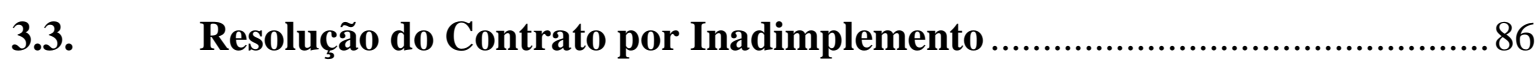

3.4. Inadequação da Unicidade de Fundamento Dogmático.................................91

4. A SOCIEDADE LIMITADA NO CÓDIGO CIVIL DE 2002 …......................95

4.1. Nota Crítica ao Código Civil de 2002 em Matéria de Sociedades ................95

4.2. Normas Aplicáveis à Sociedade Limitada ...................................................102

4.3. A Sociedade Limitada entre as Sociedades de Pessoas e de Capitais........112

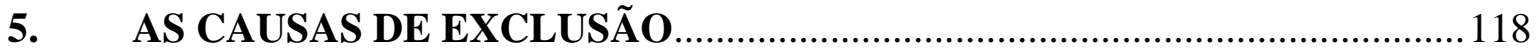

5.1. Crítica à Doutrina do Rompimento da Affectio Societatis ..........................127

5.2. Violação do Dever de Colaboração ……………………………………….....137

5.2.1. Não Integralização da Quota Social...............................................................138 
5.2.2. Incapacidade Superveniente e não Prestação de Serviço............................... 141

5.3. Violação do Dever de Lealdade .................................................................. 146

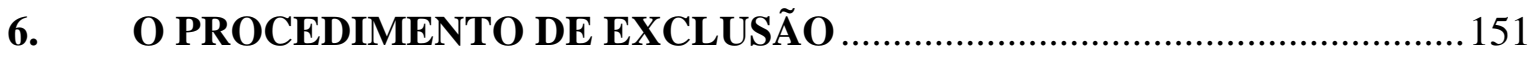

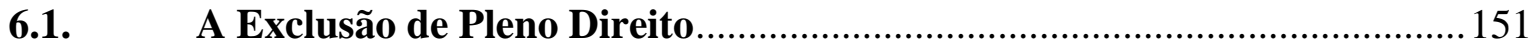

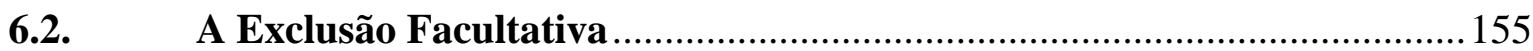

6.2.1. Titularidade do Direito Material de Exclusão e Legitimidade Ativa............. 155

6.2.2. $\quad$ Prazo para a Exclusão e para a Reação à Exclusão ........................................ 159

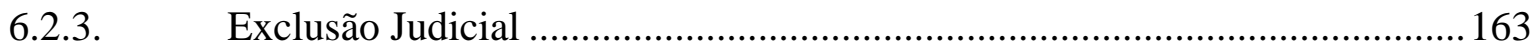

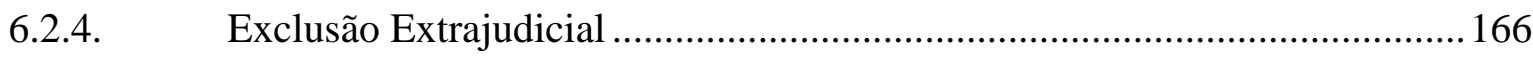

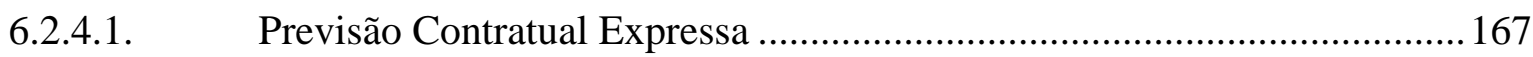

6.2.4.2. Reunião e Assembléia de Exclusão e "Defesa” do Excluendo....................172

7. ASPECTOS CONTROVERSOS DA EXCLUSÃO DE SÓCIO ......................184

7.1. A Cláusula de Vedação da Exclusão de Sócio ........................................... 184

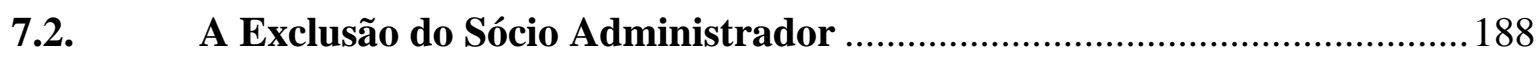

7.3. Exclusão em Sociedade com Dois Sócios................................................. 190

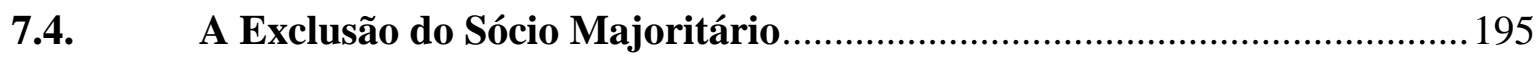

7.5. Exclusão de Sócio na Sociedade em Liquidação …..................................... 197

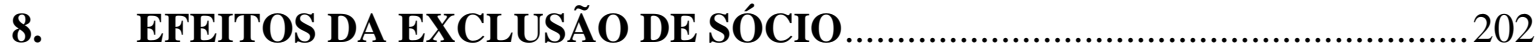

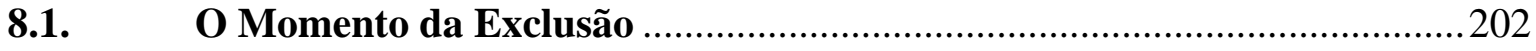

8.2. Apuração dos Haveres e Destino das Quotas do Excluído.........................206

8.3. Responsabilidade Residual do Sócio Excluído …......................................211

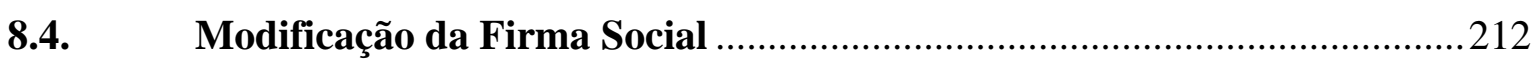

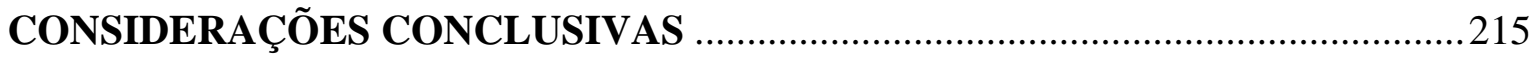

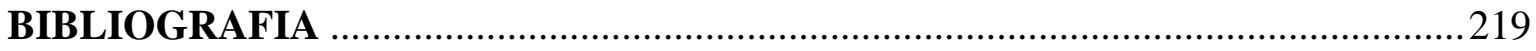

RESUMO 


\section{INTRODUÇÃO}

O presente estudo tem por objetivo analisar a atual disciplina do instituto da exclusão de sócios no Direito brasileiro, tomando em consideração o impacto da promulgação do Código Civil de 2002 (Lei Federal n ${ }^{\circ}$ 10.406/02).

A primeira e necessária delimitação do tema investigado decorre do próprio conceito de exclusão, entendido para os fins do trabalho como a perda da qualidade de sócio contrariamente à vontade do próprio quotista, ou a prescindir desta última. Dessa maneira, afastam-se do escopo da análise hipóteses como, por exemplo, a morte do sócio - na qual este, obviamente, já não mais existe como centro de imputação de direitos e obrigações ou titular de vontade - ou o seu afastamento em função de exercício de opção de compra. Neste último caso, ainda que exista oposição no momento de concretização da venda, há uma manifestação de vontade anterior que impede a caracterização do negócio como exclusão.

Além disso, também fogem ao foco principal da presente investigação as hipóteses em que a perda compulsória da qualidade de sócio é o resultado de forças externas e estranhas à sociedade. Pode-se citar, por exemplo, a hipótese em que as autoridades de defesa da concorrência determinem a venda obrigatória da participação em determinada sociedade, como condição à aprovação de uma operação de fusão. Uma outra possibilidade de tal gênero é a expropriação pelo Estado de quotas ou ações em função de questão de interesse público.

O instituto da exclusão de sócio, tal qual abordado na presente análise, é figura típica do Direito Privado e, no âmbito deste, interessa ao Direito Societário. Nesse sentido, um dos objetivos do trabalho será justamente o de sublinhar as diferenças estruturais entre os casos de exclusão de pleno direito, novidade introduzida no ordenamento brasileiro por inspiração da lei italiana, e a exclusão facultativa, tradicional objeto de análise da doutrina brasileira.

Um outro importante fator de restrição do escopo da pesquisa é o tipo societário objeto do estudo. A análise concentra-se exclusivamente nas sociedades limitadas, conforme disciplinadas no Código Civil de 2002, e as referências a outras espécies de sociedade ou 
às associações são feitas apenas para fins de comparação, analogia e suporte ao trabalho principal.

Por fim, o terceiro elemento de delimitação do tema é temporal, na medida em que o cerne da pesquisa é a disciplina contemporânea da matéria. Isso não significa que a análise histórica não seja relevante. Em razão da construção predominantemente doutrinária e jurisprudencial do instituto da exclusão de sócios no Brasil, pode-se afirmar que a investigação histórica possui importância redobrada. Um dos propósitos do trabalho é inclusive apontar como a doutrina da "dissolução parcial” continua a ecoar em nossos tribunais, com reflexos negativos, a despeito da promulgação de novas normas societárias que - com todos os seus inegáveis defeitos - despiram tal tese de sentido, uma vez que eliminaram disposições individualistas do Código Comercial de 1850, as quais determinavam a dissolução (total ou strictu sensu) da sociedade em razão de causas atinentes à pessoa de um dos sócios.

Com efeito, o trabalho se inicia com um sucinto exame do tratamento normativo atribuído à exclusão de sócios no Direito estrangeiro, para sucessivamente se debruçar sobre o longo percurso de incorporação do instituto no Direito pátrio. De qualquer modo, é importante sublinhar que o levantamento histórico possui caráter meramente ancilar, servindo apenas para contextualização e suporte da discussão da disciplina contemporânea do instituto.

No que diz respeito às justificativas para a escolha do tema, é possível identificar inúmeras razões aptas a confirmar sua relevância e sua atualidade. A exclusão de sócio possui enorme importância, tanto sob uma perspectiva estritamente conceitual e teórica, quanto em termos práticos e sob um ponto de vista sócio-econômico.

Sob a ótica dogmática e conceitual, já dizia Arturo Dalmartello, autor de uma das mais importantes obras sobre tema, que a exclusão representa uma lente de aumento que permite avaliar detalhadamente todos os aspectos e contornos do fenômeno societário ${ }^{1}$. Com efeito, a exclusão é uma questão transversal a todo o Direito Societário. O estudo de tal instituto impõe uma investigação da própria natureza dogmática do conceito de sociedade, das

\footnotetext{
1 “L'istituto dell'esclusione fornisce, per così dire, la lente d'ingrandimento che rivela, in ogni suo contorno e in ogni suo dettaglio la vera essenza giuridica della collaborazione sociale.” in A. DALMARTELLO, L’Esclusione dei Soci dalle Società Commerciali, p. 161.
} 
correlações entre empresa e sociedade, das diferenças estruturais entre os diversos tipos societários e das obrigações atribuíveis aos sócios em cada um deles.

A esse respeito, é importante mencionar que se adota como premissa para o estudo a natureza contratual das sociedades, com plena adesão à tese do contrato plurilateral também dito associativo ou de comunhão de escopo -, consolidada pelo ilustre e saudoso Professor Tullio Ascarelli ${ }^{2}$. Em tal âmbito, o instituto desponta, de fato, como um elemento de reafirmação da especialidade e autonomia da categoria dos contratos plurilaterais, na medida em que, como se argumenta a seguir, representa uma forma peculiar de incidência do preceito da resolução dos contratos por inadimplemento, antes tido como exclusivamente aplicável aos contratos bilaterais. Os Capítulos 2 e 3 do estudo são dedicados justamente à investigação do sentido e da natureza jurídica do instituto da exclusão de sócios.

Além de sua relevância estritamente conceitual, convém recordar que, em termos sócioeconômicos, a grande difusão das sociedades limitadas no Brasil faz com que todas as questões que possuam um relevante impacto sobre a sua estabilidade e preservação categoria na qual o instituto da exclusão inequivocamente se enquadra - tenham igualmente uma grande importância para a realidade das atividades econômicas no país. Com efeito, levantamento do Departamento Nacional de Registro Comércio - DNRC indica que entre o período de 1985 a 2003, as sociedades limitadas (então regidas pelo Decreto 3.708/19) representaram mais de 99,9\% das sociedades constituídas no Brasil ${ }^{3}$.

A defesa da atualidade de um tema objeto de pesquisa jurídica, por outro lado, requer a percepção de que o debate doutrinário que o cerca não se encontra totalmente esgotado, que as opiniões dos estudiosos não foram definitivamente decantadas pela jurisprudência, existindo ainda dúvidas a serem dirimidas, posições discordantes e questões em aberto. Também sob esse aspecto, uma investigação dedicada ao instituto da exclusão de sócios revela-se mais do que justificada. No Brasil, o debate em torno dos aspectos polêmicos do mecanismo da exclusão nunca foi definitivamente superado. Mesmo às vésperas da

\footnotetext{
${ }^{2}$ T. ASCARELLI, O Contrato Plurilateral, p. 256.

${ }^{3}$ De acordo com as estatísticas divulgadas pelo Departamento Nacional de Registro do Comércio - DNRC, no período compreendido entre 1985 e 2003 foram constituídas no país 4.300.257 sociedades limitadas, 20.080 sociedades anônimas e apenas 4.534 sociedades classificadas sobre a rubrica "outros tipos”, que exclui as sociedades cooperativas (www.dnrc.gov.br).
} 
promulgação do Código Civil de 2002, nossos tribunais produziam decisões contraditórias e a doutrina se debatia em relação a questões como a necessidade de justa causa (e o seu conteúdo) e a possibilidade de exclusão extrajudicial na presença de cláusula restritiva de deliberação majoritária.

Com a promulgação do novo diploma, entretanto, multiplicam-se as questões que exigem interpretação e análise. O Código Civil de 2002, com efeito, introduz em nosso ordenamento o primeiro tratamento minimamente pormenorizado e sistemático do regime da exclusão de sócios, antes relegado a normas relativas ao Registro do Comércio, que apenas tangenciavam a matéria. Ao fazê-lo, contudo, o novo diploma valeu-se de um intrincado e confuso sistema de remissões. Nesse sentido, é natural e inevitável que proliferem opiniões divergentes na doutrina sobre os mais variados aspectos da nova norma, fato que por si já tornaria o tema da exclusão merecedor de uma análise mais detida.

É por essa razão que o Capítulo 4 do presente trabalho dedica-se a traçar um breve panorama das novas normas societárias introduzidas pelo Código Civil de 2002, avaliandoas criticamente. $\mathrm{O}$ foco principal de tal passagem do estudo é reconstruir o perfil elementar da atual sociedade limitada, o qual, não sem grande esforço hermenêutico, emerge da confusa e intrincada rede de remissões normativas e referências estabelecida pelo novo diploma.

Tendo já apontado as diferenças estruturais entre as hipóteses de exclusão de pleno direito e exclusão facultativa e eleito a tese da resolução contratual como fundamento deste último instituto, o passo seguinte é evidentemente examinar os deveres atribuídos ou atribuíveis aos quotistas, nos termos da lei ou consoante o contrato social, cujo inadimplemento poderia ensejar a aplicação da expulsão de sócio. Desse modo, o Capítulo 5 destina-se à análise das principais causas de exclusão.

No Capítulo 6, trata-se dos procedimentos de exclusão, identificando três vias principais estabelecidas, ainda que nebulosamente, pelo Código Civil de 2002: a exclusão de pleno direito, a exclusão judicial e a exclusão extrajudicial - estas duas últimas, formas de exclusão facultativa. Enfrentam-se, no Capítulo 7, algumas questões particularmente controversas em matéria de exclusão, tal como a exclusão em sociedade com dois sócios. 
O Capítulo 8 aborda, enfim, as principais conseqüências decorrentes da efetivação da expulsão de um quotista, sem contudo aprofundar-se nos detalhes da questão da apuração de haveres.

Em relação às fontes doutrinárias consultadas, é de se apontar o número relativamente pequeno de monografias, publicadas no Brasil, dedicadas especificamente à exclusão de sócios, o qual não parece estar à altura da relevância do tema. Convém recordar que a interpretação prevalente do artigo 18, do revogado Decreto 3.708/19, tornou aplicável à antiga sociedade por quotas a maior parte dos institutos típicos das sociedades anônimas. Este fato, somado ao próprio laconismo do Decreto 3.708/19, permitia a transposição quase direta às sociedades por quotas da maior parte das conclusões obtidas no âmbito das sociedades anônimas e compeliu os doutrinadores a se dedicarem quase exclusivamente a estas últimas, a despeito da maior difusão do primeiro tipo societário. Assim, determinados temas, como a própria questão da exclusão de sócios, tornaram-se em certa medida “órfãos” da devida atenção dos estudiosos, os quais acabaram dedicando-se com maior ênfase a temas que eram, concomitantemente, relevantes tanto para a sociedade anônima quanto para a antiga sociedade por quotas, tal como o direito de recesso.

No que diz respeito ao exame do Direito estrangeiro e, em particular, à análise de Direito Comparado, merecem destaque sem dúvida alguma a jurisprudência e a doutrina italianas. Tal atenção especial se justifica pelo papel pioneiro exercido pelos juristas italianos nesta matéria, mesmo antes da promulgação do Código Civil de 1942, mas também pela inegável inspiração de tal diploma na elaboração das normas societárias do Código Civil Brasileiro de 2002. De qualquer forma, ocorre assinalar que, enquanto a análise panorâmica do Direito estrangeiro foi sobreposta ao levantamento histórico, no Capítulo 1, o trabalho não contém um capítulo dedicado especificamente à investigação de Direito Comparado. Esta última está disseminada nas demais passagens do estudo, mas apenas pontualmente, em suporte a análise do próprio ordenamento brasileiro. 


\title{
1. HISTÓRICO E DIREITO ESTRANGEIRO
}

\begin{abstract}
"Nem os Romanos tiverão commercio qual oje se pratica, e usa, e entende, e conhece, nem o commercio d'oje é ja o commercio do seculo passado."
\end{abstract}

José Ferreira Borges, Londres, $1830^{1}$

\subsection{Período Romano e Medieval}

O objetivo essencial do instituto da exclusão de sócios é conciliar uma mudança no quadro de sócios com a sobrevivência e permanência da sociedade, enquanto centro de imputação de direitos e obrigações. É este dado elementar que liga umbilicalmente, tanto em termos de fundamentos dogmáticos, quanto no que tange o seu desenvolvimento histórico, a exclusão de sócios a outras hipóteses de resolução do vínculo social limitadamente a um dos sócios, tais como o recesso, a retirada unilateral de sócio ou a substituição de sócio falecido.

A despeito da ampla naturalidade com a qual tais conceitos são aceitos na atualidade, a preservação da sociedade ante uma alteração na composição do quadro de sócios encerrou uma profunda transformação e uma verdadeira ruptura em relação aos paradigmas clássicos que orientaram os caminhos do Direito Societário durante séculos e, mesmo hoje, ainda fazem sentir seu peso. Com efeito, sob influência direta do Direito Romano, defendeu-se por gerações a idéia de que a retirada de qualquer sócio, a qualquer título e por menor que fosse a sua participação proporcional, acarretaria inelutavelmente o fim da respectiva sociedade ${ }^{2}$.

Em Roma, a societas possuía uma natureza personalíssima e a ela aplicavam-se os cânones gerais do direito contratual daquele período (o qual era estranho à noção de contrato plurilateral ou associativo). Como conseqüência, enquanto modificação de um dos dados elementares da avença, o afastamento de uma das partes - seja por morte, ausência,

\footnotetext{
${ }^{1}$ J. BORGES, Jurisprudencia do Contracto-Mercantil, e Arestos dos Codigos e Tribunais das Nações mais Cultas da Europa, p. VIII.

${ }^{2}$ M. PERRINO, Le Tecniche di Esclusione del Socio dalla Società, p. 60. H. ESTRELLA, Apuração dos Haveres de Sócio, p. 25.
} 
incapacidade superveniente ou simples ato (discricionário) de vontade - tinha como resultado inevitável a dissolução completa de todo o respectivo arranjo contratual ${ }^{3}$. A continuação das mesmas atividades pelos sócios remanescentes era sempre vista como a formação de um contrato de sociedade absolutamente novo e não como sobrevivência do contrato original.

Foi apenas no período de Justiniano que se admitiu algum temperamento ao rigor de tal postulado, com o reconhecimento da possibilidade de continuação de uma sociedade em caso de acordo entre os herdeiros do sócio falecido (que assumiriam seus direitos e obrigações) e os sócios supérstites ${ }^{4}$.

Assim, os estudiosos da matéria afirmam que o Direito Romano não teria conhecido sequer formas preliminares do instituto da exclusão de sócio, em nenhuma de suas fases ${ }^{5}$. Isso não significa, naturalmente, que a tradição romana não tenha exercido um relevante papel no desenvolvimento da exclusão de sócio. Ocorre, entretanto, que tal influência foi essencialmente negativa e conservadora, quase que invariavelmente colocando-se como um obstáculo à admissão doutrinária de soluções de cunho prático, forjadas no quotidiano da atividade comercial (entre as quais a exclusão de sócio).

De fato, toda a história da exclusão de sócios é marcada por um permanente embate entre, de um lado, a visão formalista e conservadora, que propugnava pelo término da sociedade como conseqüência lógica e necessária do afastamento de qualquer dos sócios, e, do outro lado, um entendimento pragmático, com origem predominantemente na prática contratual quotidiana dos mercadores e em sua jurisprudência corporativa, as quais atentavam mais à solução de dificuldades concretas do que à reverência aos preceitos clássicos.

\footnotetext{
3 "Se cierra de esta manera el paso a toda possibilidad de salida o, incluso, sustitución de un socio de la sociedad, con la consequencia de que ésta permanezca subsistiendo entre los restantes.” in R. VILLAVERDE, La Exclusion de Socios - Causas Legales, p. 30.

4 "L'unico temperamento che il tardo diritto romano portò al rigore di questa disciplina [dissolução da sociedade por questões particulares a um dos sócios], è quello d'aver riconosciuto la validità dei patti di non scioglimento pel caso di morte del socio." in A. DALMARTELLO, L'Esclusione del Socio dalle Società Commerciali, p. 7. No mesmo sentido, R. VILLAVERDE, La Exclusion de Socios - Causas Legales, p. 31.

5 "L'istituto della esclusione dei soci non ha traccia nel diritto privato romano,..." in A. DALMARTELLO, L’Esclusione dei Soci dalle Società Commerciali, p. 2.
} 
Inicialmente, em um tempo em que as sociedades não possuíam personalidade jurídica própria e, sequer, formas preliminares de autonomia patrimonial, a aplicação dos preceitos clássicos romanos não representaria uma dificuldade insuperável. Com efeito, se a existência de uma determinada sociedade projeta efeitos predominantemente na esfera patrimonial interna do próprio grupo de sócios (tal como a moderna sociedade em conta de participação), o seu término e sua substituição por outra sociedade representam uma operação não sujeita a maiores dificuldades, extremamente próxima a um simples acerto de contas.

Tratava-se, efetivamente, de uma operação com conseqüências lógicas e formais mais vistosas do que seus desdobramentos concretos e materiais; uma questão mais relevante e interessante para o jurista do que para o comerciante. Em tal hipótese, o recurso ao arcabouço teórico e normativo aplicável aos contratos bilaterais - o qual determina o término do vínculo em função da perda de um de seus elementos essenciais: (in casu) uma das partes - não traria inconvenientes especialmente graves.

Entretanto, na medida em que se intensifica a projeção dos efeitos externos da sociedade (projeção esta que seria eventualmente consagrada com a atribuição de personalidade jurídica própria e autonomia patrimonial perfeita), a necessária extinção do ente societário em função de qualquer alteração em seu quadro de sócios se demonstra uma resposta cada vez mais indesejada e problemática.

Neste segundo cenário, o término da sociedade deixa de ser uma mera questão de reorganização de vínculos internos entre os sócios remanescentes, um simples acerto de contas entre particulares, mas passa a afetar as relações da sociedade com seus clientes, parceiros e credores. Com efeito, a sociedade personalizada age e comparece no mercado em nome próprio, obrigando e vinculando seu patrimônio exclusivo, distinto daquele dos sócios, ainda que existam hipóteses de comunicação entre ambas as esferas. Desse modo, as relações com terceiros se formam diretamente com a própria sociedade e não, como ocorria anteriormente, com um dos sócios, que age em nome e no lugar da coletividade de consócios, amparando-se em uma comunhão especial de bens inter partes.

Em tal novo cenário, a imposição do término da sociedade e sua substituição por outra têm como resultado a extinção de um ente ativo, cuja própria presença no mercado possui um 
valor econômico a ser tutelado pelo Direito. A principal conseqüência, portanto, é que a sobrevivência e a permanência do revestimento jurídico ou, melhor, ente titular da empresa coletiva - a sociedade - passaram a influir na continuidade e sucesso da atividade desenvolvida - a empresa propriamente dita.

A estreita vinculação entre a atividade empresarial e os efeitos nocivos da extinção da sociedade - somada ao espaço propício que o ordenamento corporativo dos mercadores oferecia para a atividade criadora e pragmática de novos institutos jurídicos, à margem e muitas vezes em colisão com os postulados clássicos - explica a razão pela qual o desenvolvimento do instituto da exclusão de sócios ocorreu quase que exclusivamente no âmbito da sociedade comercial. Na maioria dos ordenamentos, não se reconheceu expressamente a possibilidade de exclusão de sócios no âmbito da sociedade civil - salvo por empréstimo e transposição do Direito Comercial -, sendo possível citar como exemplo a própria experiência brasileira anterior à vigência do Código Civil de 2002.

No período medieval, por outro lado, já não era tanto o peso da herança romanística que impedia a aceitação do remédio da exclusão, mas o escopo e uso das sociedades que não eram com ele de todo compatíveis, não favorecendo a sua aplicação ou desenvolvimento. As sociedades em tal período eram, efetivamente, ou a continuação econômica de vínculos familiares - tais como as embrionárias sociedades em nome coletivo -, ou então, estruturas destinadas a camuflar sob as vestes de lucro a vedada usura ou simplesmente encobrir o exercício da atividade comercial por parte daqueles para quem esta era vedada ou tida como indigna - caso das primeiras sociedades em comandita ${ }^{6}$.

Na primeira hipótese, estavam marcadas por forte vínculo pessoal entre os sócios ${ }^{7}$, enquanto na segunda os vínculos entre o comerciante que assumia a frente do negócio e o membro do clero ou da nobreza que figurava como capitalista oculto poderiam ser desfeitos de acordo com as regras aplicáveis aos contratos bilaterais.

Os primeiros passos em favor da explícita e irrestrita aceitação do instituto da exclusão de sócios foram tomados no universo do Direito Comercial germânico, ao final do período medieval, primeiramente em âmbito contratual, mas com subseqüente chancela da

\footnotetext{
${ }^{6}$ F. GALGANO, Lex Mercatoria, p. 44.

${ }^{7}$ A. DALMARTELLO, L'Esclusione dei Soci dalle Società Commerciali, p. 5-6.
} 
jurisprudência. Dalmartello afirma que o pioneirismo germânico nesse campo se deve à visão menos rígida e cristalizada dos cânones do Direito Romano que então prevalecia naquela região ${ }^{8}$.

\subsection{A Positivação do Instituto}

\subsubsection{Alemanha e Áustria}

No período de consolidação dos estados nacionais europeus, institutos jurídicos como a exclusão de sócio, nascidos no seio do direito corporativo mercantil, foram absorvidos pelo ordenamento estatal e plasmados por algumas das primeiras codificações. Nesse sentido, os primeiros diplomas a admitirem expressamente o instituto da exclusão de sócio foram o Código Territorial Prussiano (Allgemeines Preußisches Landrecht) de 1794 e o Código Civil Austríaco de $1811^{9}$.

De fato, os parágrafos 273 e 274 da Parte I, Seção VII, Capítulo I, do Código Territorial Prussiano já estabeleciam a possibilidade de expulsão, sempre sob supervisão de autoridade estatal, dos sócios que: (i) intencional e repetidamente agissem de forma contrária aos interesses sociais, (ii) atuassem de forma fraudulenta contra a sociedade, (iii) fossem condenados criminalmente ou (iv) fossem declarados ausentes ${ }^{10}$. Na mesma esteira, o parágrafo 1.210 do Código Civil Austríaco de 1811 admitia expressamente a hipótese de exclusão de sócio nos casos de: (i) inadimplemento de obrigações essenciais estabelecidas no contrato social, (ii) falência e (iii) quebra de confiança em relação a um dos sócios, resultante de ação penal por crime doloso que pudesse sujeitá-lo a pena superior a um ano ${ }^{11}$.

\footnotetext{
8 "Un ambiente giuridico del tutto diverso si venne, invece, creando nel moderno diritto germanico, in cui, com'è noto, gli istituti romanistici non furono accolti in forma rigida e cristallizzata, ma, per ragioni storiche e scientifiche particolari, vennero abbandonati a quella naturale evoluzione che trasforma l'istituto stesso e lo adatta alle sempre nuove esigenze pratiche." in A. DALMARTELLO, L'Esclusione dei Soci dalle Società Commerciali, p. 9. Miguel Reale também identifica a origem germânica do instituto, in M. REALE, A exclusão de Sócio das Sociedades e o Registro do Comércio, p. 286.

${ }^{9}$ M. PERRINO, Le Tecniche di Esclusione del Socio dalla Società, p. 69.

10 "§ 273. Ein Mitglied, welches sich der Erfüllung seiner Pflichten beharrlich entzieht, kann noch vor Ablauf der Zeit, oder vor Beendigung des Geschäfts, von der Gesellschaft ausgeschlossen werden” e "§ 274. Noch mehr ist die Gesellschaft dazu berechtigt, wenn ein Mitglied betrüglich gegen dieselbe gehandelt hat, als ein Verbrecher bestraft, oder zur einen Verschwender gerichtlich erklärt worden ist”.

11 “§ 1210. Wenn ein Mitglied die wesentlichen Bedingungen des Vertrages nicht erfüllt; wenn es in Konkurs verfällt; wenn es durch eine oder mehrere gerichtlich strafbare Handlungen, die nur vorsätzlich begangen werden können und mit mehr als einjähriger Freiheitsstrafe bedroht sind, das Vertrauen verliert; so kann es
} 
Contudo, a positivação inicial do instituto da exclusão de sócio não marcou a definitiva superação da herança formalista e personalista do período romano. A melhor ilustração possível para a resistência de tais cânones na cultura jurídica européia reside no fato de as normas que sucederam a Lei Territorial Prussiana e o Código Civil Austríaco serem, quase sem exceção, mais conservadoras e restritivas em relação à admissão da exclusão de sócio do que aqueles primeiros e inovadores diplomas.

Nesse sentido, verifica-se que a admissibilidade da exclusão nos Códigos Comerciais alemães de 1861 e $1897^{12}$ não apenas foi enquadrada como subespécie e alternativa subsidiária da dissolução total, negando-se assim a sua qualidade de instituto autônomo ${ }^{13}$, como submetida ao requisito de entendimento unânime dos sócios remanescentes. Este retrocesso normativo se explica em grande parte pela crescente influência do movimento pandectista, que passou a orientar a formulação de várias codificações de tal período, em prejuízo da simples absorção das normas costumeiras e jurisprudenciais anteriormente vigentes.

Ainda dentro do universo normativo germânico, a lei alemã relativa às sociedades de responsabilidade limitada ( $G m b h G)$, de 20 de abril de 1892, tratou apenas da possibilidade de exclusão do sócio remisso (na forma de caducidade das quotas, conforme previsto no parágrafo 21) e da hipótese de resgate ou amortização de quotas, quando expressamente prevista no contrato social (nos termos do parágrafo 34), sem tratar das questões do recesso ou da exclusão por justa causa. Karsten Schmidt, baseando-se na exposição de motivos da referida lei, afirma que a ausência de referências às possibilidades de exclusão e recesso não foi o resultado de desatenção ou omissão acidental do legislador alemão, mas reflexo do deliberado propósito dos autores do respectivo projeto de lei de não conceder aos sócios das sociedades limitadas a prerrogativa de unilateralmente romper os vínculos societários $^{14}$.

vor Verlauf der Zeit von der Gesellschaft ausgeschlossen werden.” Vale notar que o artigo não em questão não fala em efetiva condenação e refere-se apenas a "ameaça" de aplicação da pena de privação de liberdade, ao que tudo indica em violação do princípio de presunção de inocência do réu.

${ }^{12}$ Parágrafo 140, em combinação com o parágrafo 133.

${ }^{13}$ A. DALMARTELLO, L'Esclusione dei Soci dalle Società Commerciali, p. 12.

14 "Dagegen enthält das Gesetz keine Vorschriften über den Austritt von Gesellschaftern. Das ist kein Versehen, sondern gezetzgeberische Absicht. Die Begründung von 1891 sagt: 'Den Gesellschaftern kann zwar nicht das Recht eingeräumt werden, das Gesellschaftsverhältnis einseitig aufzukündigen und aus der Gesellschaft auszutreten...” in K. SCHMIDT, Gesellschaftsrecht, p. 797. 
Como conseqüência, a confirmação da legitimidade da exclusão por justa causa no âmbito das sociedades limitadas alemãs ocorreu apenas por via de construção jurisprudencial, respeitando essencialmente dois caminhos diversos.

O primeiro deles consistiu no reconhecimento judicial da validade da cláusula de resgate explicitamente construída como cláusula de exclusão. Ou seja, graves violações dos deveres de sócio são estipuladas como uma condição suspensiva, cuja verificação enseja o nascimento do direito de a sociedade exigir o resgate da participação do sócio inadimplente $^{15}$. Em tal hipótese, em regra, deve-se seguir o procedimento para a amortização de quotas, conforme disciplinado na lei alemã, mas existem julgados que reconheceram a possibilidade de se efetivar a exclusão de um sócio por meio da compra compulsória da respectiva participação societária, desde que com base em expressa previsão contratual $^{16}$.

Mais tardiamente, parte da jurisprudência passou também a admitir, entre as sociedades limitadas alemãs com traços de sociedades de pessoas, a exclusão de sócios mesmo ante a ausência de cláusula expressa de resgate no contrato social ${ }^{17}$. Em tal caso, contudo, aplicam-se rígidos requisitos para a admissão do remédio da expulsão, a qual deve se configurar como único e último recurso possível, preferível apenas em relação à dissolução da sociedade. A exclusão deve ser o resultado de falta grave, atinente à pessoa do sócio, capaz de impossibilitar ou prejudicar gravemente a persecução do objeto social ${ }^{18}$. Além disso, entende-se que a deliberação de exclusão deve ser aprovada por sócios detentores de ao menos três quartos do total de votos (não computados os votos do sócio a ser excluído, nos termos da $4^{\mathrm{a}}$ alínea do parágrafo 47 da $G m b h G$ ). Chegou-se a tal critério por analogia

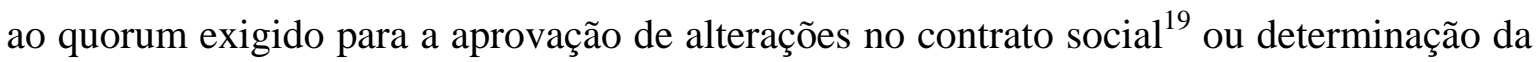
própria dissolução da sociedade ${ }^{20}$.

\footnotetext{
15 "Der Gesellschaftsvertrag kann also wie geschildert durch eine Einziehungsklausel dafür Sorge tragen, dass ein Gesellschafter, in dessen Person ein wichtiger Grund liegt, aus der GmbH ausgeschlossen werden kann...” in B. GRUNEWALD, Gesellschaftsrecht, p. 398.

${ }^{16}$ K. SCHMIDT, Gesellschaftsrecht, p. 798-799.

17 “...besteht aber Einigkeit darüber, dass auch dann, wenn der Gesellschaftsvertrag keine entsprechende Regelung enthält, ein Ausschluss möglich ist, wenn in der Person eines Gesellschafter ein wichtiger Grund liegt.” in B. GRUNEWALD, Gesellschaftsrecht, p. 398.

${ }^{18}$ K. SCHMIDT, Gesellschaftsrecht, p. 799.

${ }^{19}$ K. SCHMIDT, Gesellschaftsrecht, p. 800.

${ }^{20}$ De acordo com acórdão 173/02 da $2^{\text {a }}$ Câmara Civil do Tribunal Federal Alemão (Bundesgerichtshof BGH II ZR 173/02).
} 


\subsubsection{França}

Uma dos diplomas legais europeus que mais influenciaram os esforços de codificação de outros países - e que se ateve mais fielmente aos cânones do pandectismo em matéria de exclusão -, foi o Código Civil Napoleônico de 1804. De fato, a legislação francesa simplesmente desconsiderou o instituto da exclusão de sócio e adotou regime praticamente análogo ao vigente nos tempos romanos. Mesmo para o caso da morte de um dos sócios, o Código Napoleônico admitiu a continuação da sociedade somente mediante expressa convenção entre os remanescentes e os herdeiros do falecido (artigo 1.868). Ou seja, tratou-se meramente de repetir a solução originalmente formulada pelo direito justinianeu.

A valorização do indivíduo presente nos ideais revolucionários, alinhada e somada com os cânones herdados do direito romano, fez com que o elemento personalista prevalecesse sobre o interesse coletivo de continuidade da sociedade (em prejuízo, conseqüentemente, da preservação da empresa), nas hipóteses de modificação superveniente e involuntária do quadro de sócios.

Apenas muitos anos mais tarde, com a promulgação da Lei de 24 de julho de 1867, que introduziu no Direito Francês o conceito de sociedade com capital variável, verificou-se um reconhecimento expresso da possibilidade de exclusão. Ainda assim, a permissão legal se restringiu apenas às próprias sociedades de capital variável. Estas últimas não representam propriamente um tipo societário em separado, mas antes uma característica com a qual uma sociedade qualquer (artigo 48 da referida lei) pode se revestir por meio de expressa estipulação em seu estatuto ${ }^{21}$, nos termos da permissão legislativa.

A variabilidade do capital faz com que o ingresso e a saída de sócios tenham lugar de forma similar ao que ocorre em uma sociedade cooperativa brasileira, dotada de capital social. Ao se adotar estatutariamente o princípio da variabilidade, o ingresso de um membro implica emissão de uma nova quota e aumento do capital social, enquanto a retirada do sócio acarreta uma correspondente e automática redução do capital. As referidas operações ocorrem sem a necessidade de alteração do contrato social ou expressa

${ }^{21}$ B. CAILLAUD, L'Exclusion d'un Associé dans les Sociétés, p. 20-21. 
aprovação dos demais sócios e sem que ocorram quaisquer transações de compra, venda ou cessão de quotas, de forma que o capital social pode variar constantemente.

Nos termos do artigo 52 da lei de 1867, o estatuto social pode autorizar a assembléia geral de uma sociedade com capital variável a, motivadamente, excluir sócios da sociedade ${ }^{22}$. A sociedade de capital variável representa evidentemente uma estrutura jurídica interessante, porém incompatível com inúmeros modelos de negócios e empreendimentos que exigem um mínimo de estabilidade do capital e nos quais os sócios almejam certo controle sobre a circulação das participações e sobre a identidade e qualidades de seus consócios. Por esta razão, trata-se de uma forma jurídica com reduzida aplicação prática.

Desse modo, a autorização expressa para a admissão da exclusão de sócios no âmbito das sociedades com capital variável esteve longe de representar uma solução definitiva para o problema no Direito Francês ${ }^{23}$; a despeito ser relevante para a construção da doutrina sobre o tema, na medida em que indica claramente que o legislador não repudia em absoluto o conceito de expulsão de sócios em si.

Ante a inexistência de amparo normativo expresso para a exclusão de sócios entre as sociedades com capital fixo, a doutrina francesa trilhou um caminho muito similar àquele seguido pelos juristas brasileiros, buscando refúgio no princípio da liberdade contratual. Defende-se, assim, a idéia de que não havendo vedação explícita, não se poderia negar aos sócios o direito de estipular a possibilidade de exclusão por justa causa no contrato social $^{24}$. Este entendimento parece ser compartilhado pela maioria dos autores franceses, ainda que não seja de todo pacífico ${ }^{25}$.

\footnotetext{
22 "Seules, peu importe leurs forme, les sociétés qui adoptent la variabilité du capital peuvent prévoir dans leurs status l'exclusion de certains associes plus ou moins fautifs." in B. CAILLAUD, L'Exclusion d'un Associé dans les Sociétés, p. 15.

${ }^{23}$ Para um interessante e peculiar lamento sobre a situação geral do instituto da exclusão de sócios no Direito Francês: "Dans les clubs et les associations, il existe des procédures d'exclusion à l'encontre des membres devenus indésirables. L’Église n’hésite pás à excommunier ceux de se fidèles quin et se plient pas à sa doctrine. L'État lui-même peut retirer sa nationalité à un citoyen à titre de sanction dans des circonstances exceptionnelles. Peut-on de la même façon retirer sa qualité de citoyen à un associé ? La loi est muette sue ce point.” in M. COZIAN, A. VIANDIER, F. DEBOISSY, Manuel - Droit de Sociétés, p. 148.

24 "Lorsque les fondateurs d'une société désirent introduire dans les statuts un texte permettant l'exclusion de certains associés dans de cas expressément désignés, deux questions sont à résoudre : l'exclusion est-elle valable et, cette validité admise, en quels termes doit-on rédiger la clause ? [...], le point central du débat concerne l’interprétation du silence du législateur à ce sujet. Ce mutisme suscite des réactions contradictoires et catégoriques mais, pour notre part, nous estimons qu'il laisse aux associés le libre choix dans la rédaction de leurs conventions." (sem grifo no original) in B. CAILLAUD, L'Exclusion d'un Associé dans les Sociétés, p. 239. No mesmo sentido e mais recentemente: “Rien n'interdit d'insérer dans les status une clause
} 
Muito mais delicada e problemática, entretanto, é a questão da exclusão de sócios sem o respaldo de cláusula estatuária expressa. Bernard Caillaud confirma o entendimento essencialmente unânime dos juristas franceses no sentido de negar a pura e simples atribuição de tal prerrogativa à maioria ou mesmo à totalidade dos sócios remanescentes, fora do amparo de explícita disposição do contrato social ${ }^{26}$. Ainda assim, restaria aberta uma possibilidade de exclusão, na forma do recurso ao artigo 1.184 do Código Civil Francês, que trata do princípio geral da resolução contratual por inadimplemento ${ }^{27}$. De forma análoga à doutrina brasileira da dissolução parcial, os sócios prejudicados pelo inadimplemento de um consócio poderiam solicitar em juízo o término não do vínculo contratual como um todo, mas apenas limitadamente a este último, tendo em vista as características específicas do contrato de sociedade e a necessidade de preservação da empresa.

Tal possibilidade existiria apenas nas sociedades com claro caráter contratual e, mesmo entre estas, acarretaria um grave risco para a continuação da sociedade. Com efeito, entendem os doutrinadores franceses que, em tal hipótese, sempre caberia ao juiz a faculdade de determinar a efetiva dissolução e liquidação da sociedade, nos termos do artigo 1.871 do Código Civil Francês ${ }^{28}$.

autorisant l'exclusion d'un associé si certains événements nettement précisés à l'avance vienent à se réaliser.” in M. COZIAN, A. VIANDIER, F. DEBOISSY, Manuel - Droit de Sociétés, p. 148-149.

25 A este respeito, Rafael Garcia Villaverde realizou extensa análise de Direito Comparado e cita como autores franceses favoráveis ao reconhecimento da validade da cláusula de exclusão o próprio Bernard Caillaud, além de Escarra e Ripert (entre outros). Entre os contrários à validade da disposição, contudo, estariam Pic e Thaller. R. VILLAVERDE, La Exclusion de Socios - Causas Legales, p. 60-61.

26 “En l'absence de clause statutaire prévoyant une telle mesure, un associé peut-il être menacé d'exclusion dans une société à capital fixe ? Tous les auteurs sont d'accord, et nous sommes avec eux, pour interdire aux seuls coassociés, même unanimes, de prendre une décision d'exclusion, quelle que soit la gravité de la faute. Malgré ses graves inconvénients, la seule action possible de leur part demeure la demande en dissolution juduciaire de l'article 1871 du Code civil.” (sem grifo no original) in B. CAILLAUD, L'Exclusion d'un Associé dans les Sociétés, p. 261.

${ }^{27}$ Código Civil Francês, artigo 1184: “La condition résolutoire est toujours sous-entendue dans le contrats synallagmatiques, pour le cas où l'une des deux parties ne satisfera point à son engagement. Dans ce cas, le contract n'est point résolu de plein droit. La partie envers laquelle l'engagement n’a point été exécuté a le choix ou de forcer l'autre à l'exécution de la convention lorsqu'elle est possible, ou d'en demander la résolution avec dommages et intérêts. La résolution doit être demandée en justice , et il peut être accordé défendeur un délai selon le circonstances.” A aplicação do referido artigo ao contrato de sociedade, exige naturalmente uma compreensão ampla e não técnica do termo "signalágmatico" empregado em tal artigo, entendendo-o não em distinção e oposição aos contratos plurilaterais ou associativos, mas no sentido de “oneroso”. A este respeito B. CAILLAUD, L'Exclusion d'un Associé dans les Sociétés, p. 262.

${ }^{28}$ Código Civil Francês, artigo 1871: "La dissolution des sociétés à terme ne peut être demandée par l'un dés associés avant le terme convenu, qu'autant qu'il y en a de justes motifs, come lorsqu'un autre associé manque à ses engagements, ou qu'une infirmité habituelle le rend inhabile aux affaires de la société, ou autres cas semblable, dont la légitimité et la gravité son laissées a l’arbitrage des juges.” A este respeito, 
É importante, de qualquer modo, registrar uma tendência do Direito francês contemporâneo de favorecer a exclusão de sócios, como se verifica na disciplina dos tipos societários mais recentes. Uma perfeita ilustração de tal movimento é a sociedade por ações simplificada (société par actions simplifiée ou S.A.S.), instituída pela Lei $\mathrm{n}^{\circ}$ 2001420, de 15 de maio de 2001. De fato, graças à redação imposta pela referida lei, os artigos 227-16 e 227-17 do Código de Comércio Francês atribuem expressamente aos sócios de uma sociedade por ações simplificada o poder de disciplinar, por meio do estatuto social: (i) a venda obrigatória de ações e (ii) a suspensão de direitos não-pecuniários do sócio, (iii) bem como a sua exclusão.

A validade da cláusula de exclusão de sócio é também expressamente reconhecida no âmbito da sociéte d'exercice liberál ou S.E.L., uma sociedade de natureza civil que, como o próprio indica, destina-se ao exercício coletivo das profissões liberais, e da société européene, tipo societário estabelecido pelas normas comunitárias ${ }^{29}$.

\subsubsection{Espanha}

O Direito Comercial espanhol destaca-se como um interessante exemplo histórico intermediário entre os sistemas germânicos e a experiência francesa ${ }^{30}$. Por um lado, o Código Comercial Espanhol de 1829 não privilegiou a continuação da sociedade, tampouco a preservação da empresa, ao arrolar como hipóteses de dissolução diversos fatos atinentes exclusivamente à pessoa de um ou alguns dos consócios, tais como: morte, doença, interdição e falência de sócio, ou mesmo a mera vontade de um deles, no caso das sociedades constituídas por prazo indeterminado (artigos 329 e 333). Nesse aspecto, seguiu-se claramente o exemplo do artigo 1.865 do Código Civil Napoleônico.

Caillaud afirma que “Jusqu'ici, l'éventualité d’une exclusion en l'absence de clause statutaire existe seulement dans les sociétés à caractère contractuel, à la suite d'un manquement grave commis para un membre vis-à-vis de ses obligations sociales. L'appréciation souveraine appartient aux juges qui restent toujours libres de choisir entre l'exclusion, véritable dissolution partielle fondée sur l'article 1184, et la dissolution totale de la société, dissolution pour justes motifs de l'article 1871 du Code Civil qui demeure la solution de principe.” in B. CAILLAUD, L'Exclusion d'un Associé dans les Sociétés, p. 263.

${ }^{29}$ M. COZIAN, A. VIANDIER, F. DEBOISSY, Manuel - Droit de Sociétés, p. 149.

30 "El Código de comercio español de 1829, recibe probablemente influencia múltiple. En primer lugar, la francesa puede deducirse del vasto catálogo de causas de disolución de la sociedade que se recogen en los textos legales, [...] Parece, por otra parte, que la influencia germánica puede haber determinado la acogida, haciendo excepción a la línea mantenida por el Derecho francés, de la institución de la exclusion del socio.” in R. VILLAVERDE, La Exclusion de Socios - Causas Legales, p. 82. 
Por outro lado, ao reconhecer expressamente a possibilidade de exclusão de sócios, o ordenamento espanhol aproximou-se da sistemática prussiana. Nesse sentido, previu-se a possibilidade de exclusão para os casos de: (i) uso de fundos da sociedade em interesse próprio, (ii) exercício de poderes de administração por parte de sócio não autorizado contratualmente a fazê-lo, (iii) fraude na administração ou contabilidade da sociedade, (iv) não integralização da própria quota (após ser instado a fazê-lo), (v) concorrência ilícita com a sociedade e (vi) ausência injustificada do sócio obrigado a prestar serviços à sociedade (após ser instado a retornar) ${ }^{31}$.

Um relevante passo adiante para a consolidação do instituto da exclusão de sócios na Espanha seria dado com a promulgação do Código Comercial de 1885, o qual foi além da fixação de um rol delimitado de hipóteses de exclusão, incluindo uma norma aberta, referente a quaisquer causas graves justificadoras da aplicação do remédio extremo da expulsão, nos termos do parágrafo $7^{\circ}$ do artigo $218^{32}$.

Atualmente, porém, os dois principais tipos societários espanhóis - sociedade anônima e limitada - são regulados por leis especiais. A sociedade anônima é regulada pela Lei $\mathrm{n}^{0} 19$, de 25 de julho de 1989, que em seus artigos 43 a 45 estabelece as conseqüências da não integralização de ações, prevendo a suspensão dos direitos do acionista remisso, a sucessiva tentativa de venda de suas ações (em bolsa, com intervenção de corretor ou tabelião, conforme o caso) e, somente após o eventual fracasso desta última, a amortização das ações em questão.

A disciplina das sociedades limitadas espanholas encontra-se na Lei $n^{\circ} 2$, de 23 de março de 1995. O artigo 98 de tal lei prevê a exclusão do sócio inadimplente em relação a obrigações acessórias $^{33}$ e do sócio administrador que competir com a sociedade ou for condenado definitivamente a indenizá-la por perdas - neste último caso, os danos causados à sociedade devem ser resultantes de (i) violação da lei ou do (ii) contrato social, ou (iii) desídia do administrador. Para sócios com participação inferior a um quarto do capital

\footnotetext{
${ }^{31}$ Artigos 300, 307, 312, 323, 316 e 326.

${ }^{32}$ R. VILLAVERDE, La Exclusion de Socios - Causas Legales, p. 87-88. É interessante notar que se trata de movimento simetricamente contrário àquele verificado na Itália, onde a referida norma aberta, presente no Código Comercial de 1865, foi suprimida no Código Comercial Italiano de 1882.

${ }^{33} \mathrm{O}$ artigo 22 da referida lei define obrigações acessórias como todas aquelas estipuladas pelo contrato social que não se refiram à integralização de quotas.
} 
social, a exclusão pode ser pronunciada diretamente em juízo. Caso a participação seja superior, deverá ocorrer por meio de decisão judicial, precedida de aprovação da assembléia geral (artigo 99).

Ressalvada a rara possibilidade de acordo entre os sócios remanescentes e o excluído, a lei espanhola atribui ao auditor de contas da sociedade o dever de avaliar os haveres do quotista expulso, ainda que a norma em questão não determine de antemão o método a ser empregado em tal tarefa. Os haveres devem ser pagos em dinheiro pela sociedade, dentro do prazo de dois meses a contar do término da avaliação. Os honorários do avaliador devem ser pagos pela sociedade, mas podem ser compensados do valor devido ao excluído. É interessante notar que a lei espanhola determina expressamente a redução do capital como parte da liquidação da participação e impõe ao sócio excluído (bem como ao que exerce o recesso), por remissão expressa, o mesmo regime de responsabilidade aplicável à hipótese de redução do capital social com restituição de bens ou dinheiro aos sócios (artigo 103).

Cabe observar, por fim, que a lei espanhola adotou disciplina relativamente branda em relação aos sócios remissos, na esfera das sociedades limitadas. A alínea “d” do artigo 16 da Lei $\mathrm{n}^{\circ}$ 2, de 23 de março de 1995, estabeleceu que a falta de plena integralização do capital social da sociedade limitada em constituição representa causa de nulidade desta última. Em relação a aumentos do capital social de sociedade já constituída, o artigo 77 da mesma lei prevê meramente a decadência das quotas não integralizadas ou, caso a plena integralização tenha sido expressamente colocada como condição prévia, o cancelamento da operação de aumento. Não se coloca, portanto, como alternativa para a sociedade e para os demais sócios, as clássicas opções de excluir o remisso, reduzir sua participação ou cobrar judicialmente o valor ou os bens prometidos por meio da subscrição.

\subsubsection{Itália}

Na Itália - cuja evolução normativa merece uma análise relativamente menos apressada, não apenas pela relevância e preponderância que couberam a sua doutrina no desenvolvimento geral do instituto ${ }^{34}$, mas também pela influência que exerceu sobre a

\footnotetext{
${ }^{34}$ Apenas como exemplo: "El estudio del Derecho comparado presenta por una parte la possibilidad de empleo de legislaciones y doctrina - básicamente italianas - como instrumento imprescindible de ayuda a la
} 
formulação da legislação brasileira contemporânea ${ }^{35}$-, o reconhecimento legal expresso do instituto da exclusão de sócios ocorreu com a promulgação do Código Comercial de 1865.

O artigo 124 do referido diploma reconhecia a possibilidade de exclusão de sócios nas hipóteses de: (i) uso da firma ou do capital da sociedade pelo sócio administrador para fins particulares, (ii) fraude na administração da sociedade ou em sua contabilidade, (iii) ausência injustificada do sócio administrador, mesmo após ser intimado a retornar, (iv) ingerência do sócio não administrador sem que tal prerrogativa esteja prevista nos atos constitutivos, (v) não integralização de quotas, mesmo após a devida constituição em mora, (vi) falência do sócio e (vii) qualquer situação de grave inadimplemento dos deveres de sócio.

O próprio artigo 124 ressalvava ainda o fato de que a consumação da exclusão não isenta o sócio excluído do dever de indenização pelos danos que tenha causado à sociedade. $\mathrm{O}$ artigo 125, a seu turno, afirmava expressamente - com o presumível intuito de impedir qualquer interpretação conservadora que levasse a um retorno ao sistema anterior, de inspiração romana - que a exclusão não implicava dissolução da sociedade. O artigo 125 tratou também, ainda que de forma sucinta, da apuração de haveres, imputando ao sócio excluído a participação nas perdas sociais verificadas até a data da exclusão e assegurando à sociedade a possibilidade de reter os lucros a ele atribuíveis até o levantamento do balanço social sucessivo.

Existem dois aspectos especialmente notáveis no tratamento dado ao instituto da exclusão de sócios pelo Código Comercial Italiano de 1865. O primeiro consiste na autonomia atribuída à questão, dentro da organização do texto do Código. Ao invés abordar a exclusão como parte do tema da dissolução da sociedade por fatos atinentes à pessoa de um dos sócios, o legislador italiano não apenas tratou da exclusão como um instituto em si, como também lhe atribuiu uma seção própria no corpo de tal diploma legal (Título VII, Capítulo I, Seção IV). Para o Professor Dalmartello, tais fatos demonstram o inequívoco

interpretación directa de nuestros textos legales debido al paralelismo con los españoles.” (sem grifo no original) in R. VILLAVERDE, La Exclusion de Socios - Causas Legales, p. 25.

${ }^{35}$ W. BULGARELLI, A Teoria Jurídica da Empresa - Análise Jurídica da Empresarialidade, p. 7. 
reconhecimento da importância e da autonomia conceitual do instituto da exclusão pela nova legislação ${ }^{36}$.

Além disso, e certamente com maior relevância prática, ocorre observar que o Código de 1865 (tal como o Código Espanhol de 1885, mencionado anteriormente) continha uma norma aberta em relação à exclusão. Ao admitir o afastamento do sócio por qualquer inadimplemento grave de seus deveres em relação à sociedade ${ }^{37}$, o Código de 1865 não se restringiu a um número predeterminado de possibilidades de exclusão. Concedeu-se, assim, grande flexibilidade para a identificação do que seria "inadimplemento grave" dentro de cada realidade societária concreta, em uma clara valorização do princípio da conservação da empresa.

O Código Comercial Italiano de 1882, entretanto, refletindo o fenômeno anteriormente mencionado de crescente influência dos cânones romanistas e clássicos, recuou nesta matéria e aboliu a norma que expressamente previa a exclusão como um remédio genérico para quaisquer hipóteses de inadimplemento grave, caminhando, portanto, na direção de um regime numerus clausus de hipóteses de afastamento dos sócios.

Em seu artigo 186, o Código de 1882 admitia a exclusão de sócios, nas sociedades em nome coletivo ou em comandita, nas hipóteses de: (i) não integralização de quotas, após a constituição em mora do sócio, (ii) ausência injustificada de sócio administrador que não retorna após ser instado a fazê-lo, (iii) fraude contábil ou na administração por parte do sócio administrador, (iv) uso indevido da firma ou de capitais da sociedade por parte do sócio administrador, (v) ingerência na administração por parte do sócio com responsabilidade ilimitada (desde que houvesse administrador nomeado), (vi) o não ressarcimento de danos ou divisão de vantagens conseguidas com o uso não autorizado da firma ou dos capitais sociais, por parte de sócio não administrador com responsabilidade ilimitada e (vii) falência, interdição ou inabilitação do sócio.

\footnotetext{
${ }^{36}$ A. DALMARTELLO, L'Esclusione dei Soci dalle Società Commerciali, p. 15-16.

${ }^{37} \mathrm{O}$ artigo 124 do Código Comercial Italiano de 1865 estabelecia, de fato, que: "Può essere escluso dalla società: il socio amministratore, che si vale della firma e dei capitali sociali ad uso proprio, che commette frodi nell'amministrazione o nella contabilità, che si assenta ed intimato non torna, né giustifica le ragioni dell'assenza; il socio che prende ingerenza nell'amministrazione senza averne facoltà dall'atto di società; il socio che costituito in mora, non eseguisce il pagamento della sua quota sociale; il socio caduto in fallimento, e in generale quando concorrano fatti che costituiscono grave inadempimento delle obbligazioni del socio....” (sem grifo no original).
} 
Especificamente no caso das sociedades em nome coletivo, representava ainda uma hipótese de exclusão a concorrência desleal ou a participação em sociedades concorrentes na qualidade de sócio de responsabilidade ilimitada. Nas sociedades em comandita, a participação - ainda que indireta (por exemplo, por meio de procuração) do comanditário na administração também ensejaria a sua exclusão. A despeito da extensa lista de possibilidades de exclusão - e provavelmente em função dela -, a norma aberta de admissão expressa da exclusão por inadimplemento grave teria sido considerada desnecessária pelos membros da comissão responsável pela formulação do novo código Comercial Italiano e simplesmente suprimida da legislação de tal país ${ }^{38}$.

Poderia ter ocorrido, desse modo, um marcante retrocesso na admissibilidade da exclusão, similar ao que ocorreu entre as primeiras legislações germânicas e aquelas promulgadas na segunda metade século XIX. Esta opção legislativa do Código Comercial Italiano de 1882, à primeira vista absolutamente restritiva, motivou, contudo, uma ampla discussão sobre o fundamento jurídico da exclusão de sócios ${ }^{39}$ que ecoou em inúmeros estudos posteriores sobre o tema.

O aspecto central de tal debate doutrinário residia no fato de que, conforme o entendimento que se adotasse, seria ou não possível admitir hipóteses de exclusão não expressamente previstas pelo Código Comercial de 1882. Nesse contexto, seguindo a classificação que ao que tudo indica foi inicialmente formulada por Dalmartello, surgiram três grupos principais de explicações - ou, teorias básicas - para a exclusão de sócio: (i) disciplina legal taxativa, (ii) poder corporativo disciplinar e (iii) resolução do contrato por inadimplemento ${ }^{40}$.

A primeira delas não representava mais do que a confirmação da interpretação mais restritiva possível das disposições do Código Comercial de 1882. A teoria da disciplina legal taxativa escorava-se no artigo $4^{\circ}$ das disposizioni sull'applicazione delle leggi do Código Civil de 1865 - norma equivalente à Lei de Introdução ao Código Civil brasileira para afirmar que a exclusão de sócios, pelo seu caráter punitivo e excepcional, apenas

\footnotetext{
${ }^{38}$ A. DALMARTELLO, L’Esclusione dei Soci dalle Società Commerciali, p. 18.

39 “Tale mancata previsione e, per contro, la elencazione delle cause di esclusione nell'art. 186 fecero sorgere, nel vigore del codice di commercio del 1882, un vivace dibattito in merito alla tassatività o meno delle cause di esclusione e alla possibilità per la società di prevedere ulteriori ipotesi di applicazione dell'istituto.” in B. ACQUAS, C. LECIS, L'Esclusione del Socio nelle Società di Persone, p. 9.

${ }^{40}$ Os argumentos de cada uma dessas teorias e seus desdobramentos são discutidos de forma mais detida no Capítulo 3 do presente estudo.
} 
poderia ter lugar quando explicitamente prevista pela legislação e sempre nos estritos limites desta.

As duas outras posições doutrinárias, ainda que sob fundamentos marcadamente diferentes, concebem um campo muito mais amplo para a aplicação do remédio da exclusão. Nos termos da teoria do poder disciplinar corporativo, a prerrogativa de excluir um sócio seria intrínseca e inerente a todos os entes associativos, uma suposta decorrência lógica do direito da sociedade de preservar a própria existência. Seria, assim, uma verdadeira expressão de uma ascendência hierárquica ou poder da sociedade sobre a pessoa do sócio.

A explicação contratualista, a seu turno, identifica os fundamentos dogmáticos da exclusão de sócio como uma forma muito peculiar de incidência da regra geral da resolução do contrato por inadimplemento grave de uma das partes. Nessa esteira, uma vez que se entendesse a sociedade como um contrato, seria possível aplicar a ela a regra geral de término por inadimplemento, ainda que a falta do sócio concretamente verificada não estivesse expressamente compreendida no rol de possibilidades de exclusão do artigo 186 do Código Comercial de 1882.

Exatamente pela necessidade de se dobrar às características próprias dos contratos plurilaterais ou associativos, o preceito geral deve ser de aplicado de forma particular aos vínculos societários. Desse modo, ao invés de ter como conseqüência o rompimento completo do contrato, tal como naturalmente se verifica quando se recorre à resolução por inadimplemento em um contrato bilateral, o inadimplemento de um dos sócios levaria ao "término parcial” do contrato de sociedade, afetando somente os vínculos entre um dos sócios e a sociedade.

Ainda que confrontada com a posição inicialmente contrária da maior parte da doutrina, a jurisprudência italiana colocou-se a favor da interpretação extensiva das hipóteses de 
exclusão, desde que houvesse previsão contratual expressa a respeito ${ }^{41}$. Eventualmente, a visão contratualista da exclusão de sócios acabaria por prevalecer ${ }^{42}$.

Cumpre observar, de qualquer modo, que apesar das mencionadas críticas o Código Comercial Italiano de 1882 também introduziu relevantes avanços em matéria de exclusão de sócios. De fato, a nova legislação estabeleceu o conceito de liquidação da quota e determinou o pagamento dos haveres devidos ao sócio excluído unicamente em dinheiro ${ }^{43}$. Dessa forma, esclareceu-se definitivamente que ao excluído não caberia nada mais do que um crédito pecuniário contra a sociedade, sendo-lhe vedado exigir a entrega ou restituição de qualquer bem ou direito específico com o qual tivesse contribuído para a formação do capital social. Trata-se de expressão do princípio da conservação da empresa, pois se impede assim que a sociedade seja privada de bens ou direitos essenciais à sua atividade.

O Código Civil Italiano de 1942 disciplinou, em seu artigo 2.286, a possibilidade de exclusão de sócios de sociedades de pessoas nos casos de (i) grave inadimplemento de obrigações derivadas da lei ou do contrato social, (ii) interdição e inabilitação de sócio ou (iii) sua condenação a pena que vedasse o acesso a cargos públicos. É relevante o fato de que, nos termos do artigo 2.287, atribuiu-se à maioria dos sócios o poder de pronunciar a exclusão extrajudicialmente ${ }^{44}$. Adicionalmente, o artigo 2.288 qualificou os eventos de falência do sócio ou liquidação de sua quota para a satisfação de credores pessoais como eventos de exclusão de pleno direito ${ }^{45}$. A exclusão de sócios entre as sociedades cooperativas, por seu turno, foi regulada pelo artigo 2.533 do mesmo diploma.

\footnotetext{
${ }^{41}$ Esclarece Corrado Lecis a esse respeito que: "La giurisprudenza formatasi nel vigore del codice di commercio del 1882 interpretò le norme in modo difforme dall'orientamento dottrinario richiamato segnalando come gli statuti sociali potessero aggiungere altri motivi di esclusione a quelli previsti dalla legge che, pertanto, non erano da considerarsi tassativi." in B. ACQUAS, C. LECIS, L'Esclusione del Socio nelle Società di Persone, p. 9.

${ }^{42}$ É possível citar como exceção o trabalho de Innocenti, que entende que a exclusão fundamenta-se em disciplina legal taxativa. O. INNOCENTI, L'Esclusione del Socio, p. 190.

${ }^{43}$ M. PERRINO, Le Tecniche di Esclusione del Socio dalla Società, p. 71.

44 “Qui [Código de 1942] basti sottolineare come un'autentica svolta [...] l'attribuzione alla maggioranza dei soci del potere di dar direttamente luogo all'esclusione, rinviando l'intervento giudiziale all'accertamento successivo, su opposizione dell'escluso, dell'effettiva ricorrenza delle cause addotte a giustificazione del provvedimento...” in M. PERRINO, Le Tecniche di Esclusione del Socio dalla Società, p. 74.

45 “...cause di esclusione di diritto, in cui cioè l'esclusione è conseguenza automatica del verificarsi di determinati fatti a carico del socio, senza necessità del ricorso all'autorità giudiziaria, né di una manifestazione di volontà sociale.” in M. PERRINO, Le Tecniche di Esclusione del Socio dalla Società, p. 74.
} 
O Código Italiano serviu de evidente inspiração para as normas de Direito Comercial e, em especial, de Direito Societário contidas no Código Civil Brasileiro de 2002. Basta mencionar, como exemplos de maior destaque, a unificação parcial do Direito das Obrigações, a adoção da Teoria da Empresa, a criação do tipo societário "sociedade simples” e a organização do texto tomando este último como regime de base para as demais formas de sociedade.

Contudo, exatamente em função da influência que a experiência italiana exerceu sobre a nova legislação brasileira, é importante salientar também algumas das grandes diferenças que existem nos fundamentos do Direito Societário em ambas as jurisdições, as quais limitaram sobremaneira a aplicação do instituto da exclusão na Itália ao longo do século XX.

Em primeiro lugar, observa-se como a divisão entre sociedades de pessoa e de capitais possui, na Itália, conseqüências muito mais profundas do que no ordenamento brasileiro, na medida em que não se atribui ou reconhece personalidade jurídica própria no âmbito das primeiras (sociedades simples, em nome coletivo e em comandita simples), mas apenas entre estas últimas (sociedade anônima, em comandita por ações e limitada, bem como as cooperativas). De fato, para os doutrinadores italianos, a imperfeita autonomia patrimonial existente nas sociedades simples, em nome coletivo e em comandita simples - decorrente da responsabilidade ilimitada de ao menos parte dos sócios em relação às dividas sociais impede que sejam consideradas entes plenamente dotados de personalidade jurídica própria.

Para explicar a separação e especialização do patrimônio social em tais casos, mas também a própria possibilidade de as mencionadas sociedades despersonalizadas atuarem no mercado sob a própria denominação, os estudiosos italianos recorreram ao conceito de autonomia patrimonial imperfeita ou "subjetividade jurídica”,46 que se pode grosseiramente traduzir como o reconhecimento normativo da sociedade de pessoas como

\footnotetext{
46 "Il codice attuale, [...], ha distinto fra le società di persone e le società di capitali. Alle prime ha riconosciuto la semplice autonomia patrimoniale, in quanto ha reso il patrimonio sociale insensibile (in maggiore o minore misura a seconda dei casi) alle vicende relative ai patrimoni individuali dei soci; alle seconde invece ha mantenuto la personalità giuridica.” in F. CORSI e F. FERRARA JR., Gli Imprenditori e Le Società, p. 194.
} 
um centro autônomo de interesses somado a um patrimônio separado, mesmo que desprovida de plena e perfeita personalidade jurídica.

Mais importante para a presente análise, entretanto, é o fato de que a sociedade limitada italiana, nos anos sucessivos à promulgação do Código de 1942, ter sido tratada como uma mera versão simplificada da sociedade por ações, pertencendo expressamente ao universo das sociedades de capitais. Ocorre que a aplicação do remédio da exclusão no Direito italiano, ressalvado o afastamento do sócio remisso, era limitada à esfera das sociedades de pessoas. Desse modo, não se admitiu durante longo período a hipótese de exclusão de sócios por justa causa nas sociedades limitadas, mas somente a decadência de quotas por falta da devida integralização. A sociedade limitada italiana foi inicialmente concebida como uma versão simplificada da sociedade anônima ${ }^{47}$ e, portanto, a ela não se estendeu o instituto da exclusão de sócios, tido como ferramenta típica das sociedades de pessoas. Admitia-se a exclusão na sociedade limitada, portanto, somente em relação ao sócio remisso, nos termos do artigo 2.466 do Código Civil de 1942.

Como conseqüência, a maior parte do debate sobre o instituto da exclusão de sócios no Direito italiano girou, durante longo tempo, em torno das sociedades com regime de responsabilidade ilimitada de ao menos parte dos sócios.

De qualquer modo, é importante ressaltar que, como resultado da fixação de valores mínimos de capital social e patrimônio líquido para a constituição e operação das sociedades de capitais ${ }^{48}$, as sociedades baseadas no regime de responsabilidade ilimitada dos sócios existem em grande número na Itália e têm efetiva e ampla aplicação prática - ao contrário do Brasil, onde possuem uma existência substancialmente legislativa e teórica. Assim, foi possível a formação de um relevante arcabouço jurisprudencial e doutrinário sobre o tema da exclusão, ainda que tal hipótese não estivesse aberta às sociedades limitadas.

\footnotetext{
47 “La società a responsabilità limitata era, nell’originario disegno del codice civile, una sorta di società per azioni in piccolo, diversa da questa, come si esprimeva la relazione ministeriale (n. 1015), per 'la struttura più intima."’ in F. GALGANO, Le Nuove Società di Capitali e Cooperative, p. 483.

${ }^{48}$ As sociedades anônimas italianas devem ter um capital social mínimo de cento e vinte mil euros, enquanto para as sociedades limitadas vigora o piso de dez mil euros (respectivamente artigos 2.327 e 2.464, parágrafo $4^{\mathrm{o}}$, do Código Civil Italiano). Além disso, caso se verifiquem perdas superiores a um terço do capital social, este deve ser obrigatoriamente reduzido e, atingindo patamar aquém dos limites mínimos da lei, deve ser imediatamente recomposto (artigo 2.446). Caso contrário, a sociedade deve ser transformada em tipo societário que admita aquele valor de capital social ou, alternativamente, ser dissolvida (artigo 2.447).
} 
Foi apenas com a ampla reforma do Direito Societário italiano, realizada por meio do Decreto Legislativo $\mathrm{n}^{\circ}$ 6, de 17 de janeiro de 2003, o qual introduziu o artigo 2.437-bis no Código Civil Italiano ${ }^{49}$, que finalmente se admitiu a exclusão de sócios por justa causa entre as sociedades limitadas italianas. Por meio da referida reforma, reconheceu-se o caráter intermediário da sociedade limitada italiana (società a responsabilità limitata), entre as sociedades de capitais e de pessoas $^{50}$, e se promoveu deliberadamente uma aproximação entre e o regime destas últimas e a disciplina da sociedade limitada ${ }^{51}$.

Ainda assim, a possibilidade de exclusão nas sociedades limitadas está sujeita a duas graves restrições. A primeira é evidentemente a necessidade de cláusula expressa para a deliberação da exclusão ${ }^{52}$. Além disso, no que tange a apuração de haveres, o artigo 2.437bis faz remissão ao regime fixado pelo artigo 2.437, concernente o direito de recesso, mas expressamente afasta a possibilidade de liquidação da quota do sócio excluído por meio da redução do capital social. A exclusão de sócio na sociedade limitada italiana, portanto, apenas poderá ser consumada por meio uma das duas outras formas de liquidação da quota previstas para hipóteses de recesso, quais sejam: a aplicação de reservas disponíveis para a aquisição da quota do excluído pela própria sociedade ou a aquisição da participação do sócio excluído por outros sócios ou por terceiros pelo valor fixado para o reembolso ${ }^{53}$.

\footnotetext{
${ }^{49}$ Artigo 2.437-bis: "L'atto costitutivo può prevedere specifiche ipotesi di esclusione per giusta causa del socio. In tal caso si applicano le disposizioni del precedente articolo [relativo ao direito de recesso], esclusa la possibilità del rimborso della partecipazione mediante riduzione del capitale sociale”.

50 "Dalla riforma del 2003 è emersa una diversa concezione di questo tipo di società, che si presta ad essere piuttosto considerato come un tipo intermediario fra le società di persone e la società per azioni. Di questa c'è, fondatamente, la disciplina dei rapporti esterni, mentre i rapporti interni fra soci si possono modellare secondo lo schema delle società di persone.” in F. GALGANO, Le Nuove Società di Capitali e Cooperative, p. 483.

51 "Il processo di personalizzazione della struttura societaria della nuova s.r.l. ha portato all'introduzione dell'istituto dell'esclusione facoltativa del socio, consentita prima della riforma soltanto per le società di persone e le società cooperative; per le s.r.l. era prevista solo l'ipotesi di esclusione del socio moroso nei versamenti, quando erano falliti i tentativi di procedere alla vendita coattiva per mancanza di compratori..." in G. LO CASCIO (Coord.), Società a Responsabilità Limitata, p. 155.

52 “È previsto un solo caso legale di esclusione: a norma del comma $3^{\circ}$ dell'art. 2466, dev'essere escluso il socio moroso quando sono falliti i tentativi di vendita della quota. Ampio è, invece, lo spazio concesso in questo campo all'autonomia dei soci: la norma dell'art. 2473-bis stabilisce, così introducendo un istituto finora riservato alle società di persone e, in limiti assai più contenuti, alle società cooperative, che l'atto costitutivo può prevedere specifiche ipotesi di esclusione per giusta causa...” in V. BUONOCORE, La Riforma del Diritto Societario, p. 181.

53 "A differenza che nel recesso, non è invece possibile il rimborso della quota mediante la riduzione del capitale sociale. La preclusione è diretta a tutelare la integrità del patrimonio sociale, ma il divieto vuole forse esercitare anche un effetto dissuasivo nei confronti dei soci in relazione ad iniziative che potrebbero pregiudicare la stessa sopravvivenza della società, spingendoli a ricercare soluzioni in grado di risolvere i conflitti interni o comunque le difficoltà di funzionamento interno della società, senza pregiudicare i creditori sociali e terzi.” in G. LO CASCIO (Coord.), Società a Responsabilità Limitata, p. 159.
} 


\subsubsection{Portugal}

No período anterior à promulgação do seu Código Civil de 1867 - conhecido como o Código Seabra -, Portugal ainda estava sujeito às disposições de Direito Societário das Ordenações Filipinas $^{54}$. De fato, em obra cuja primeira edição foi lançada em 1830, Jose Ferreira Borges denunciava exasperadamente o atraso das normas portuguesas em matéria de direito das sociedades ${ }^{55}$.

Contudo, não obstante o declarado propósito de aproximar o ordenamento lusitano da disciplina das nações mais avançadas da Europa, Borges previu em seus arestos a dissolução da sociedade por questões pessoais dos sócios, tais como morte, insanidade, abuso, falência, mau comportamento ou mesmo, nas sociedades por prazo indeterminado, pela mera vontade de qualquer dos consócios $^{56}$. O silêncio do Código Civil Português de 1867 sobre o tema veio apenas confirmar tal tendência conservadora do Direito Societário português, relativamente ao instituto da exclusão de sócios. O Código Comercial Português, de 28 de Junho de 1888, também não reconheceu expressamente a possibilidade de exclusão por justa causa.

Portugal, por outro lado, foi um dos primeiros países a seguir o exemplo alemão e a instituir o tipo societário das sociedades com regime de responsabilidade limitada, denominadas “sociedades por quotas”, por meio da Lei de 11 de abril de 1901 . O artigo 12 da referida lei estabeleceu regime extremamente rigoroso em relação ao sócio remisso, ao fixar não apenas a possibilidade de sua exclusão, como também a perda em favor da sociedade dos pagamentos parciais eventualmente realizados, sem prejuízo de sua responsabilidade pelas perdas e danos causados pelo seu inadimplemento. Ainda sim, a lei portuguesa das sociedades por quotas não previu a aplicação da exclusão em outras hipóteses de violação dos deveres de sócio.

\footnotetext{
${ }^{54}$ Tais disposições são discutidas no próximo tópico deste capítulo, relativo ao desenvolvimento histórico do instituto da exclusão no ordenamento brasileiro.

55 "Eu tenho pois trabalhado para fazer conhecer qual fosse este contracto no tempo dos Romanos; como delles para a nossa Ordenação, aonde ficou estacionario ate oje, em quanto que todas as mais naçoens se avantajarão e desinvolverão.” In J. BORGES, Jurisprudencia do Contracto-Mercantil, e Arestos dos Codigos e Tribunais das Nações mais Cultas da Europa, p. X.

${ }^{56}$ J. BORGES, Jurisprudencia do Contracto-Mercantil, e Arestos dos Codigos e Tribunais das Nações mais Cultas da Europa, p. 150, 153 e 154.
} 
O silêncio que então prevalecia na legislação portuguesa em relação à possibilidade de exclusão de sócios por justa causa motivou a elaboração da notável monografia do Professor Avelãs Nunes sobre a matéria ${ }^{57}$. Em sua obra, o autor construiu a tese de que o direito de exclusão seria uma cláusula geral, implícita nos atos constitutivos de quaisquer sociedades, uma vez que representa um instrumento de preservação da própria sociedade e, por desdobramento, da empresa.

De qualquer modo, o novo Código Civil de Portugal, de 25 de novembro de 1966, superou em grande parte a questão. A nova lei, em seu artigo 1.003, não apenas autorizou a disciplina da exclusão no contrato social da sociedade, como previu tal solução para os casos de: (i) grave violação do sócio nas obrigações com a sociedade, (ii) interdição ou inabilitação, (iii) impossibilidade de prestação de serviços, por parte do sócio de indústria, e (iv) perecimento de bem conferido ao capital da sociedade, por causa não imputável aos administradores.

O artigo 1.005 da mesma lei fixou o procedimento de exclusão, estabelecendo o critério da deliberação majoritária, não computados os votos do excluendo. A eficácia da deliberação de exclusão ocorre somente após o decurso do prazo de trinta dias após a notificação do sócio que se busca excluir. Nesse período, cabe ao sócio buscar a impugnação da decisão. Como exceção à via extrajudicial, na sociedade composta por apenas dois sócios, a exclusão apenas pode ser solicitada em juízo.

Em 02 de setembro de 1986, por meio do Decreto-Lei nº 262/86, foi promulgado o Código das Sociedades Comerciais Português, cujo artigo 186 tratou especificamente da exclusão de sócios no âmbito das sociedades comerciais. O tratamento do tema foi um pouco mais extenso do que o do Código Civil de 1966 e, além das causas de exclusão nele já previstas, foram também arrolados como motivos de expulsão do sócio: (i) o afastamento da administração em função de atos culposos prejudiciais à sociedade, (ii) insolvência e falência e (iii) violação do dever de não concorrência com a sociedade. Em relação a este último ponto, convém observar que, de acordo com o artigo 180 do Decreto-Lei nº 262/86, é vedado ao sócio realizar - seja em nome próprio, na posição de sócio de responsabilidade ilimitada de outra sociedade, ou como sócio de responsabilidade limitada, mas com

\footnotetext{
${ }^{57}$ A. NUNES, O Direito de Exclusão de Sócios nas Sociedades Comerciais, p. 69.
} 
participação superior a vinte por cento do capital - atividade incluída no objeto social da própria sociedade, ainda que de fato não exercida naquele momento.

O Código das Sociedades Comerciais estabeleceu, outrossim, procedimento mais rigoroso para a exclusão de sócio, exigindo quorum mínimo de três quartos dos votos - excluída do cômputo, como de praxe, a participação do sócio que se quer excluir. Além disso, a lei sujeitou a deliberação de exclusão a um prazo decadencial de noventa dias, cuja contagem inicia-se na data em que qualquer dos administradores tome ciência dos fatos capazes de ensejar a respectiva expulsão do sócio. Trata-se de uma verdadeira presunção ipso iure de tolerância à conduta do sócio infrator.

Ainda que sob certos aspectos seja discutível a fixação de prazo relativamente breve para dar curso à exclusão ${ }^{58}$, é forçoso reconhecer que, se os sócios e a sociedade podem tolerar uma determinada conduta ou omissão do sócio faltoso por três meses, provavelmente o fato não representa uma questão grave a ponto de justificar a aplicação de um remédio tão extremo quanto a exclusão. Cumpre observar, ademais, que a regra em questão impede que eventos antigos e já superados sejam, em outro momento e contexto, convenientemente trazidos à tona por outros sócios, como mero pretexto e instrumento de pressão.

\subsubsection{Common Law}

Apenas a título de breve nota, tendo em vista os percursos históricos marcadamente distintos, cumpre também fazer uma alusão aos traços mais relevantes do instituto da exclusão de sócios nos países em que prevalece o Common Law.

No Direito Societário de tais jurisdições, existe uma divisão essencial, ainda que com nuances e zonas de sobreposição, entre as partnerships, de um lado, e as registered companies (Inglaterra) ou corporations (Estado Unidos), do outro. Grosso modo, tal divisão corresponde, mutatis mutandis, à separação presente no Direito continental entre sociedades não-personificadas e sociedades personificadas, ou, ao menos no sentido atribuído a tais termos na Alemanha e na Itália, sociedades de pessoas e de capitais. As

\footnotetext{
${ }^{58}$ Pode-se argumentar, por exemplo, que tal disposição inibe os demais sócios a tentarem convencer o consócio infrator a reformular sua conduta e impede que entendimentos e negociações para a composição amigável de dificuldades possam se prolongar pelo prazo que eventualmente se mostra necessário ou adequado.
} 
partnerships possuem estrutura institucional mais simples e presumem relações mais estreitas entre os sócios, bem como o engajamento direto destes nas atividades desenvolvidas $^{59}$. É no âmbito destas últimas, portanto, que a exclusão de sócios encontra efetiva aplicação, já que nas companies ou corporations costuma prevalecer a aplicação de instrumentos mais próximos aos da sociedade anônima, tal a como a tutela do conflito de interesse.

O Partnership Act britânico de 1890 permite em seu artigo $25^{60}$ - via uma leitura contrario sensu - a exclusão de associados por deliberação da maioria, desde que tal prerrogativa lhes seja atribuída por prévia e expressa convenção ${ }^{61}$.

Nos Estados Unidos, a disciplina das partnerships também foi marcadamente orientada pela promulgação de normas escritas expressas (diplomas legais ou statutes), fato peculiar para ordenamentos baseados principalmente na regra do precedente e no direito consuetudinário $^{62}$. Tratando-se, contudo, de matéria sujeita majoritariamente à competência legislativa dos Estados-membros (ressalvadas as normas atinentes ao funcionamento do mercado de capitais), verificou-se um grande esforço na edição e divulgação de leis uniformes.

Nesse sentido, merece destaque o Uniform Partnership Act - UPA, de 1914, que foi ao seu tempo adotado por todos Estados-membros daquele país, com a exceção de Louisiana ${ }^{63}$. O referido diploma, que ainda se encontra em vigor em diversos Estados-membros, possui regime bastante conservador em relação a mudanças no quadro de sócios, prevendo que a saída de qualquer sócio da sociedade acarreta a sua dissolução.

\footnotetext{
59 "Registered Companies are indeed the offspring of partnership but of course at the present day the modifications and adaptations are so considerable that they have obscured the original partnership law on which they were based, and company law is now a distinct and extensive subject whose differences from that of partnership are more marked than its resemblances. The reason for this development is that the law of the partnership is centred on principles of personal control and unlimited liability...” F. POLLOCK, On the Law of Partnership, p. 11.

${ }^{60}$ Partnership Act, 1890, art. 25: "No majority of the partners can expel any partner unless a power to do so has been conferred by express agreement between the partners." in F. POLLOCK, On the Law of Partnership, p. 11.

61 "Under this section, [...], a majority not only must not but can not expel a partner without a power expressly conferred. An attempt to expel a partner without such power, or without complying with the conditions of good faith applicable to all powers of majorities [...] is merely void and of no effect.” (grifo no original) in POLLOCK, On the Law of Partnership, p. 79.

62 "Although partnership had a rich history under the common law, it has long been governed by statute." in M. EISENBERG, Corporations and Other Business Organizations, p. 23.

${ }^{63}$ M. EISENBERG, Corporations and Other Business Organizations, p. 23.
} 
Em 1994, foi formulado o Revised Uniform Partnership Act - RUPA, com o propósito explícito de atualizar e substituir o UPA, mas que ainda não teve a mesma difusão e aceitação entre os diversos Estados que mereceu o diploma que o antecedeu. O RUPA tratou extensamente da questão da exclusão e reverteu a posição conservadora do UPA relativamente ao término da sociedade em casos de mudanças no quadro de sócios ${ }^{64}$.

O artigo 601(3) autorizou a expulsão de sócio nos termos de expressa convenção entre os consócios. O artigo 601(4) prevê, por outro lado, as hipóteses em que a exclusão de sócio pode ser determinada pelo voto unânime dos demais parceiros, ainda que não esteja amparada por expresso acordo. Tais hipóteses consistem em: (i) caráter ilícito da permanência do sócio na sociedade, (ii) cessão de todos (ou quase todos) os direitos do sócio na sociedade para terceiros (exceto se para fins de garantia), (iii) registro de pedido de dissolução, nulidade da constituição ou suspensão de licença de atividade de sócio que seja sociedade (nestas hipóteses, o sócio dispõe de noventa dias para regularizar a sua situação) e (iv) dissolução e liquidação de sócio que seja uma sociedade.

O artigo 601(5) do RUPA estabelece, a seu turno, as hipóteses em que a exclusão de um sócio pode ser solicitada em juízo, a pedido da sociedade ou de qualquer dos demais sócios: (i) prática de atos faltosos que prejudiquem gravemente os negócios da sociedade, (ii) violação intencional ou reiterada do acordo de sociedade ou das regras gerais de conduta estipuladas pela lei (artigo 404 do RUPA), (iii) adoção de atitude que torne inviável a devida condução dos negócios da sociedade na presença de tal sócio. Nos termos do artigo 103(b), é expressamente vedado aos membros da partnership modificar por via de acordo ou convenção a extensão e o escopo das disposições do referido artigo 601(5).

A falência e a insolvência do sócio (e eventos correlacionados) representam, igualmente, justificativas válidas para a exclusão (artigo 601(6)). Em relação ao sócio pessoa natural, consoante o artigo 601(7), (i) a nomeação de tutor ou administrador de seus bens e (ii) a

\footnotetext{
${ }^{64}$ Conforme as notas oficiais da National Conference of Commissioners on Uniform State Laws (comentários ao Artigo $6^{\circ}$ ): "RUPA dramatically changes the law governing partnership breakups and dissolution. [...] Under RUPA, unlike the UPA, the dissociation of a partner does not necessarily cause a dissolution and winding up of the business of the partnership.” No mesmo sentido: “...RUPA, unlike UPA, does not provide that every termination of a person's status as a partner - every dissociation - causes dissolution. Instead, the key issue is whether dissociation has occurred, and what are the consequences of the kind of dissociation that occurred.” (grifo no original) in M. EISENBERG, Corporations and Other Business Organizations, p. 65.
} 
declaração judicial de incapacidade de desempenho de suas funções perante a sociedade também têm como conseqüência a exclusão.

\subsection{Desenvolvimento do Instituto no Brasil}

Nos anos imediatamente subseqüentes à independência política do Brasil e até que o jovem estado fosse capaz de consolidar e organizar sua própria legislação comercial - o que ocorreria principalmente por meio do Código Comercial de 1850 - continuamos a compartilhar com Portugal algumas normas herdadas do período de dominação colonial. De fato, a Lei do Império de 20 de outubro de 1823 reconheceu e confirmou expressamente a vigência no Brasil de todas as normas promulgadas pelo Reino de Portugal até 25 de abril de 1821 (artigo $1^{\circ}$ ), bem como de certo número delimitado de atos posteriores indicados expressamente em documento anexo (artigo $2^{\circ}$ ).

Desse modo, prevaleciam ainda no Brasil, em matéria societária, as normas do Livro IV, Título XLIV, das Ordenações Filipinas, as quais, relativamente ao ingresso e retirada de sócios, eram extremamente conservadoras e ainda espelhavam essencialmente os mesmos princípios e disposições do tardo Direito Romano. Nesse sentido, as Ordenações Filipinas estabeleciam, em ao menos duas passagens ${ }^{65}$, que a morte de qualquer dos sócios levaria à dissolução e término da sociedade.

Os únicos casos em que se admitia a continuação da sociedade eram (i) a sub-rogação do falecido por seus herdeiros nas sociedades destinadas à coleta de rendas públicas ou arrendamento, de modo similar à solução romana aplicada à societas publicanorum (desde que houvesse cláusula expressa a respeito e os herdeiros fossem pessoas idôneas) e (ii) a continuação da sociedade comum (ou seja, ainda que não destinada à coleta de rendas públicas) com os sócios supervenientes, caso houvesse prévio e unânime entendimento

${ }^{65}$ Ordenações Filipinas, Livro IV, Título XLIV, caput: "E algumas vezes se faz [a sociedade] até certo tempo, outras vezes simplesmente sem limitação delle; mas ainda que se faça sem limitação de tempo, morrendo qualquer dos companheiros, logo acabará o contracto da companhia, e não passará a seus herdeiros, posto que no contracto se declare, que passe a elles; salvo se a Companhia fosse de alguma renda nossa, ou da Republica, que algumas pessoas houvessem tomado juntamente; porque nestes casos, ainda que algum dos companheiros na renda falleça, passará o tal arrendamento a seus herdeiros pelo, que elle durar, se assi foi no dito contracto declarado, e o herdeiro he pessôa diligente e idonea para perseverar na dita Companhia." Além disso, previa o parágrafo $4^{\circ}$ do mesmo Título: “O contracto de Companhia se desfaz por morte natural de qualquer dos companheiros. E ainda que fiquem outros alguns vivos, também quanto à elles acabará o dito contracto, salvo se a principio se acordasse entre todos, que o tal contracto durasse entre os que vivos ficassem.” 
entre estes últimos. Convém salientar que, neste último caso, não haveria o ingresso necessário ou automático dos herdeiros do falecido, hipótese expressamente repelida pelo caput do Título XLIV. O eventual ingresso do herdeiro estaria sujeito a acordo superveniente com os sócios remanescentes e, ainda assim, era tido pelos doutrinadores como a constituição de uma nova sociedade e não continuação daquela já existente.

Nas sociedades constituídas por prazo indeterminado, representava igualmente causa de término de todo o contrato a mera renúncia à condição de sócio por parte de qualquer de seus membros (parágrafo $5^{\circ}$ ). Por outro lado, quando a renúncia fosse o resultado de dolo ou da intenção de privar a sociedade de ganhos, ou ainda quando se tratasse de retirada antecipada no âmbito de sociedade por prazo determinado, caberia ao sócio renunciante ressarcir a “companhia” pelos danos causados ou lucros cessantes (parágrafos $6^{\circ}$ e $7^{\circ}$ ).

Nos termos do parágrafo $8^{\circ}$, a retirada antecipada do sócio na sociedade por prazo determinado apenas poderia ocorrer sem ensejar o referido dever de indenizar nas hipóteses de: (i) grave dificuldade de convívio e negociação com algum dos outros sócios (ou, nas palavras da lei, se um dos sócios fosse de “condição tão áspera e forte” que com ele não se pudesse tratar); (ii) transferência em função da realização de serviço ou atividade sob ordens do Estado; (iii) inadimplemento da sociedade em relação a uma das condições postas para o ingresso do sócio, e (iv) perda de bens do sócio usados na atividade social. É importante ressaltar, de qualquer modo, que todas as referidas hipóteses se referiam à retirada voluntária do sócio prejudicado e não daquele que causou danos ao desenvolvimento das atividades da sociedade. Com efeito, as Ordenações Filipinas nunca disciplinaram expressamente a exclusão de sócio.

O Código Comercial de 1850 trouxe diversas inovações nesta matéria em relação ao texto das Ordenações Filipinas, mas - influenciado diretamente pela posição individualista e romanista do Código Civil Francês ${ }^{66}$ - também não privilegiou ou protegeu adequada e satisfatoriamente o princípio da preservação da empresa.

66 “...o preceito vigorante no Código francês é a dissolução da sociedade, quando ocorre um infortúnio ao sócio, seja a morte natural, seja a interdição, a falência ou pela vontade de não mais permanecer na sociedade, quando esta tem prazo indeterminado. O art. 1868, do Code Civil, repetindo o modelo justinianeu, admite a continuação, no caso morte, com os herdeiros ou supérstites, se assim tiver sido estipulado no contrato. Iguais princípios foram transferidos para a codificação brasileira de 1850.” (grifo no original) in R. REQUIÃO, A Preservação da Sociedade Comercial pela Exclusão de Sócio, p. 41. 
Em seu artigo 335, o Código Comercial previa como hipóteses de dissolução ipso iure da sociedade, além da expiração de seu prazo e decisão unânime dos sócios: (i) a falência ou insolvência (“quebra”) da sociedade ou de qualquer de seus sócios, (ii) a morte de um dos sócios (salvo convenção em contrário) e (iii) a mera vontade de um dos sócios, nas sociedades constituídas por prazo indeterminado.

A seu turno, o artigo 336 do mesmo diploma previa como hipóteses que autorizariam qualquer dos sócios a solicitar em juízo a dissolução da sociedade, ao lado da impossibilidade de preenchimento de seus fins e perda de todo o capital: (i) a inabilidade ou a incapacidade moral ou civil de um ou mais sócios, confirmadas por sentença judicial; (ii) abuso, prevaricação ou violação das obrigações sociais por um dos sócios; e (iii) fuga de algum dos sócios.

A análise dos referidos dispositivos permite constatar que a continuidade da sociedade comercial brasileira da segunda metade do século XIX continuava sujeita a questões atinentes apenas à pessoa de alguns dos sócios. Cumpre reconhecer, por um lado, que o Código de 1850 introduziu, em alguns aspectos, avanços importantíssimos em relação à questão da exclusão. Pode-se citar, como exemplo, o reconhecimento expresso da possibilidade de resolução do contrato de sociedade limitadamente ao sócio remisso, com a conseqüente exclusão deste último e preservação da estrutura societária (artigo 289); ou ainda a admissão da exclusão do sócio de indústria que se envolvesse em atividades comerciais estranhas à sociedade, sem a autorização dos demais sócios. Ainda assim, de outro lado, é importante recordar que o Código Comercial de 1850 ainda atribuía à morte de sócio o mesmo tratamento preconizado pelo Direito Romano e pelas Ordenações Filipinas (dissolução strictu sensu ou “total”).

Mais grave ainda é o fato de o Código de 1850 - sob uma leitura mais literal e restritiva, anterior à construção da doutrina da “dissolução parcial” - continuar a permitir expressamente que a existência da sociedade constituída por prazo indeterminado fosse posta em cheque por mero ato de vontade de qualquer dos sócios (artigo 335, parágrafo $5^{\circ}$ ); fazendo-o, contudo, sem repetir as ressalvas constantes das Ordenações Filipinas quanto ao uso caprichoso ou doloso de tal prerrogativa ${ }^{67}$. O legislador nacional sequer

${ }^{67}$ Ordenações Filipinas, Livro IV, Título XLIV, Parágrafo 6: "Porém, quando o companheiro, que renunciar a Companhia no dito caso, o fizer por manha e engano, nem por isso ficará desobrigado da Companhia...”. 
teve, tampouco, o cuidado de repetir a ressalva contida no artigo 1.869 do Código Civil Francês, quanto à necessidade de boa-fé e escolha de momento adequado para o exercício da prerrogativa de exigir a dissolução da sociedade.

Nesse contexto, tendo em vista o espírito conservador da legislação então vigente, é certamente notável e digno de menção o caráter inovador e vanguardista das propostas formuladas pelo ilustre jurista Teixeira de Freitas, relativamente à questão da exclusão de sócios. Já em 1869, por meio de seu Esboço de Código Civil, o célebre mestre baiano propunha que a exclusão de sócios fosse expressamente admitida em determinadas hipóteses como: (i) a não integralização de quotas (artigo 3.157, parágrafos $1^{\circ}$ e $2^{\circ}$ ); mas também por (ii) arbítrio dos demais sócios se houvesse previsão contratual e (iii) por justa causa (artigo 3.219).

O conceito de "justa causa" para os fins de tal projeto, a seu turno, vinha definido no artigo 3.220 do Esbôço como: (i) violações do contrato social; (ii) descumprimento (culposo ou não) de obrigações com a sociedade ou os demais sócios; (iii) incapacidade superveniente (hipótese derrogável por meio de autorização do contrato social para sua substituição por um representante); (iv) quebra de confiança, insolvabilidade, fuga, ausência, crime, má conduta, descrédito, inimizade e desentendimento com os demais sócios; e (v) pedido de dissolução da sociedade, quando os demais consócios nela queiram continuar ${ }^{68}$.

Tendo em vista o esmero e o apuro pelos detalhes de Teixeira de Freitas, mesmo que com certo prejuízo à concisão, o Esbôço ainda especificava que as hipóteses de incapacidade superveniente autorizadoras da exclusão compreendiam a interdição, a alienação mental e a falência (exceto no caso do sócio meramente de indústria - artigo 3.222), mas não o casamento para a mulher que obtivesse autorização do marido para continuar na sociedade (artigo 3.221) ${ }^{69}$.

Caso estivessem presentes os pressupostos para a exclusão de um sócio, mas a maioria dos sócios prejudicados não quisesse realizar a sua expulsão, qualquer um destes últimos (ou seja, dos sócios prejudicados) estaria autorizado a se retirar da sociedade pela via do recesso (artigo 3.224, parágrafo $4^{\circ}$ ). O mesmo direito de recesso era atribuído ao sócio que,

${ }^{68}$ A. de FREITAS, Código Civil - Esbôço, vol. 3, p. 972-973.

${ }^{69}$ A. de FREITAS, Código Civil - Esbôço, vol. 3, p. 973. 
não por culpa sua, estivesse sujeito a alguma das hipóteses de exclusão, independentemente da eventual inação dos demais em excluí-lo (artigo 3.224, parágrafo $5^{\circ}$ ). O meticuloso jurista baiano inseriu ainda disposições a respeito do procedimento de exclusão e relativamente à apuração dos haveres do excluído ou do sócio que exerce direito de recesso (artigos 3.228 a 3.230).

Entretanto, Teixeira de Freitas foi mais além e, por força do artigo 3.058, parágrafo $1^{\circ}$, do Esbôço, sugeriu que a cláusula do contrato social que buscasse afastar $a b$ initio a possibilidade de aplicação do remédio da exclusão, em quaisquer casos, fosse considerada nula de pleno direito ${ }^{70}$.

Para que se tenha exata medida do quanto tais propostas estavam à frente de seu tempo basta mencionar que, décadas e décadas depois da divulgação do anteprojeto de código civil de Teixeira de Freitas, ainda se discutia ferozmente no Brasil a validade da cláusula de exclusão livremente pactuada pelos sócios. Mesmo em nossos dias, a nulidade da cláusula que veda a exclusão de sócios em quaisquer hipóteses é deduzida pelos doutrinadores $^{71}$, mas não expressamente prevista pelo Código Civil de 2002.

De qualquer forma, o corpulento Esboço de Teixeira de Freitas não prosperou e jamais alcançou o status de lei. As suas idéias em matéria de exclusão de sócios não foram, tampouco, incorporadas ou aproveitadas em sua época por meio de legislação extravagante.

Como conseqüência, os doutrinadores do século XIX e do início do século XX foram obrigados a procurar dentro do próprio Código Comercial de 1850 formas de contornar a inadequada e danosa solução resultante de uma interpretação literal dos artigos 335 e 336, qual seja: o término da sociedade por questões pessoais de seus sócios. Ocorre que a base normativa inicial disponível para amparar tal empreitada era extremamente singela e

\footnotetext{
70 “Art. 3.058 - Proíbe-se outrossim estipular, qualquer que seja a espécie de sociedade: $1^{\circ}$ Que qualquer dos sócios não possa renunciar, ou ser excluído, havendo para isso justa causa...” (grifo no original) in A. de FREITAS, Código Civil - Esbôço, vol. 3, p. 929.

${ }^{71}$ H. VERÇOSA, Curso de Direito Comercial, vol. 2, p. 155.
} 
tênue $^{72}$, girando essencialmente em torno dos artigos 291, 331 (com referência expressa ao artigo 486) e 339 do velho Código ${ }^{73}$.

Um dos primeiros e principais estudiosos a defender abertamente a admissibilidade da exclusão de sócios no âmbito do Código Comercial de 1850 foi José Xavier Carvalho de Mendonça $^{74}$. A sua linha de argumentação baseava-se na associação do princípio da liberdade de contratar com o princípio majoritário. Para Carvalho de Mendonça, o reconhecimento normativo expresso da validade da convenção de continuação da sociedade após o falecimento de sócio (artigo 335, parágrafo $4^{\circ}$ ) demonstrava cabalmente que não era incompatível com nosso ordenamento a idéia de preservação da sociedade, mesmo após uma alteração no quadro de sócios $^{75}$. Tal percepção era reforçada ulteriormente pela referência à despedida por causa justificada, presente no artigo 339 do Código Comercial.

Esse fato, somado à inexistência de explícita vedação no Código Comercial, redundaria na validade da cláusula do contrato social que estipulasse a exclusão de sócio por justa causa, nos termos do artigo 291 do próprio Código de $1850^{76}$, que reconhecia a validade de todas as convenções mercantis não contrárias à lei. Consoante a precisa lição do saudoso Professor Miguel Reale, não sendo contrária aos bons costumes (tanto que até mesmo explicitamente reconhecida pelo legislador em determinadas hipóteses), a convenção de

\footnotetext{
${ }^{72}$ A este respeito, o Professor Comparato constatou que “....a letra fria da lei não parece acolher essa amplitude de espectros, que é dada pela jurisprudência, à exclusão dos sócios”, acrescentando ainda que "Aplicando-se essa intercalada - ou for despedido com justa causa - procurou-se mostrar que nesta frase de canto de norma estaria consagrada uma solução geral para a exclusão de sócios.” (sem grifo no original) in F. COMPARATO, Exclusão de Sócio nas Sociedades por Cotas de Responsabilidade Limitada, p. 41-42.

73 "Esse art. 339 deu lugar a uma indagação nuclear. Ao se referir aos casos de sócio 'despedido com causa justificada', perguntava-se: a lei se reportava exclusivamente às hipóteses expressamente previstas nos arts. 289 e 317, acima mencionados? ou autorizava se estendesse o preceito a situações não compreendidas nesses dois permissivos?” in L. LEÃES, Exclusão Extrajudicial de Sócio em Sociedade por Quotas, p. 86.

${ }^{74}$ Em sua obra datada de 1926, S. Soares de Faria refere-se a Carvalho de Mendonça como um dos pioneiros nessa matéria. S. FARIA, Da Exclusão de Socios nas Sociedades de Responsabilidade Illimitada, p. 18.

75 "Se se pode estipular no contrato de sociedade que, retirado um sócio, a sociedade continue a subsistir entre os demais (cláusula comum especial para o caso de morte), é também lícito pactuar a exclusão de um sócio pelo voto da maioria em casos especiais cogitados no mesmo contrato. A sociedade regula-se pela convenção das partes sempre que esta não fôr contrária às leis comerciais.” in J. MENDONÇA, Tratado de Direito Comercial Brasileiro, Vol. III, Livro II, Parte III, § 687, p. 149.

${ }^{76}$ Lei $n^{\circ}$ 556, de 25 de junho de 1850, art. 291: “As leis particulares do comércio, a convenção das partes sempre que lhes não for contrária, e os usos comerciais, regulam toda a sorte de associação mercantil, não podendo recorrer-se ao direito civil para decisão de qualquer dúvida que se ofereça, senão na falta de ou uso comercial." (sem grifo no original).
} 
exclusão estaria incluída no espaço de autonomia da vontade das partes, delimitado contrario sensu pelo artigo 129 do Código Comercial $^{77}$.

Ou seja, ao invés de ser tomado como um obstáculo que selaria a impossibilidade técnica de recurso a tal instituto ${ }^{78}$, o silêncio da lei a respeito da matéria foi interpretado como uma autorização tácita para a convenção de exclusão nos atos constitutivos da sociedade. Além disso, o artigo 331 (segunda parte) do mesmo diploma legal havia expressamente sancionado a gestão das atividades e questões sociais por meio do critério da maioria de capital, superando a velha e personalista regra da deliberação por unanimidade ou do voto por cabeça $^{79}$.

Assim, Carvalho de Mendonça pôde arrolar entre as hipóteses de exclusão possíveis sob a égide do Código Comercial de 1850 não apenas aquelas expressamente disciplinadas pela legislação (exclusão do sócio remisso e do sócio de indústria engajado em atividade estranha à sociedade), como também uma terceira - extremamente mais ampla -, resultante de convenção expressa no contrato social ${ }^{80}$.

Em janeiro de 1900, Rui Barbosa, o Visconde de Ouro Preto e Lafayette Rodrigues Pereira publicaram pareceres defendendo precisamente a validade da cláusula de exclusão de sócios inserida no contrato social ${ }^{81}$. Alguns anos mais tarde, o artigo 14, números 6 e 18, parágrafo $3^{\circ}$, da Lei $\mathrm{n}^{\circ}$ 1.637, de 05 de janeiro de 1907, viria a reconhecer expressamente a possibilidade de as sociedades cooperativas adotarem cláusula de exclusão de seus

\footnotetext{
${ }^{77}$ M. REALE, A Exclusão de Sócio das Sociedades e o Registro do Comércio, p. 282.

78 “A omissão do Codigo deve entender-se, logicamente, no sentido de que o pensamento do legislador foi de deixar à prudência e à cautela preventiva dos contratantes o cuidado de formular, no seu contrato social, os casos e as condições em que a sociedade poderia excluir do seu gremio qualquer socio prejudicial aos seus legítimos interesses.” in S. FARIA, Da Exclusão de Socios nas Sociedades de Responsabilidade Illimitada, p. 18.

${ }^{79}$ Lei 556, de 25 de junho de 1850, art. 331: “A maioria dos sócios não tem faculdade de entrar em operações diversas das convencionadas no contrato sem o consentimento unânime de todos os sócios. Nos mais casos todos os negócios sociais serão decididos pelo voto da maioria, computado pela forma prescrita no art. 486." (sem grifo no original); e ainda dizia o art. 486: “...o parecer da maioria no valor dos interesses prevalece contra o da minoria nos mesmos interesses, ainda que esta seja representada pelo maior número de sócios e aquela por um só. Os votos computam-se na proporção dos quinhões...”.

${ }^{80}$ J. MENDONÇA, Tratado de Direito Comercial Brasileiro, Vol. III, Livro II, Parte III, § 687, p. 148-149.

${ }^{81}$ Conforme indicação de Carvalho de Mendonça, os referidos pareces teriam sido publicados no Jornal do Comércio, edição de 22 de fevereiro de 1900, conforme nota de rodapé em J. MENDONÇA, Tratado de Direito Comercial Brasileiro, Vol. III, Livro II, Parte III, § 687, p. 149. De qualquer modo, os pareceres estão transcritos na obra de Soares de Faria sobre o tema, vide S. FARIA, Da Exclusão de Socios nas Sociedades de Responsabilidade Illimitada, p. 39 e seguintes.
} 
membros no estatuto social, reforçando a idéia de que tal disposição não era intrinsecamente incompatível com os princípios gerais do ordenamento brasileiro ${ }^{82}$.

Não sendo, obviamente, o resultado de deliberado e claro desenho do legislador de 1850, a exclusão de sócios com base em cláusula contratual carecia de uma disciplina quanto ao procedimento a ser seguido para a sua concretização. A referida lacuna foi igualmente preenchida por meio de construção doutrinária e jurisprudencial (servindo o regime das sociedades cooperativas como fonte analógica), da qual Soares de Faria fez um oportuno registro, assinalando a necessidade de deliberação por escrito e sucessiva notificação do excluendo ${ }^{83}$.

Dessa forma, restou superada a mais difícil etapa do desenvolvimento histórico do instituto objeto do presente estudo: a própria admissibilidade da exclusão. Graças a um articulado e consistente esforço doutrinário de interpretação sistemática do Código Comercial de 1850, foi possível fazer reconhecer em nosso ordenamento, bem como tornar corriqueira em nossa prática comercial, a exclusão de sócio por justa causa ${ }^{84}$.

Até que finalmente se verificasse a promulgação do Código Civil de 2002, muitas normas modificariam e ajudariam a conformar o Direito Societário no Brasil, mas nenhuma delas abordou o direito de exclusão específica e extensivamente ou, tampouco, foi capaz de solucionar definitivamente seus aspectos mais polêmicos. De qualquer forma, mesmo que órfã de inovações legislativas de maior monta, a doutrina brasileira relativa à exclusão de sócios estava destinada a ir ainda muito mais longe.

\footnotetext{
${ }^{82}$ Decreto do Poder Legislativo $\mathrm{n}^{\circ}$ 1.637, de 05 de janeiro de 1907, Art. 14: "O acto constitutivo das sociedades deverá conter, sob pena de nullidade: [...] $6^{\circ}$, o modo de admissão, demissão e exclusão dos socios e as condições de retirada das entradas ou partes; ..." (sem grifo no original) e ainda "Art. 18. Os socios receberão titulos nominativos, contendo, além do contracto social, as declarações relativas a cada um, assignadas por elles e pelos representantes da sociedade. [...] § $3^{\circ} \mathrm{A}$ exclusão do socio, que só poderá ser declarada na fórma dos estatutos, será feita por termo escripto pelo gerente, que relatará todas as circumstancias do facto, o transcreverá no livro do registro e remetterá, sem demora, cópia registrada, pelo Correio, ao excluido."

83 "Nas sociedades que estudamos, o rito a seguir é este: constatada a falta do socio, os demais pronunciarão a sua exclusão, em documento devidamente assignado, e dessa resolução darão conhecimento ao socio excluido, por meio de uma notificação judicial ou por qualquer outro que possa ser provado.” in S. FARIA, Da Exclusão de Socios nas Sociedades de Responsabilidade Illimitada, p. 32.

${ }^{84}$ Miguel Reale registrava como pontos pacíficos da Doutrina em torno da metade do século passado a necessidade de cláusula contratual expressa e a pronúncia extrajudicial da exclusão, sujeita a posterior controle em juízo. M. REALE, A Exclusão de Sócio das Sociedades e o Registro do Comércio, p. 288.
} 
O Código Civil de 1916 reconheceu expressamente a personalidade jurídica das sociedades (artigo 16, inciso I), ressalvando, contudo, a sujeição das sociedades mercantis às disposições de lei especial (artigo 16, parágrafo $2^{\circ}$ ). Este fato representaria a consolidação definitiva da autonomia patrimonial das sociedades comerciais, reforçando a noção de que à sociedade caberia ter uma sorte própria, não atrelada às mazelas ou caprichos pessoais dos sócios. Em relação à sociedade civil, contudo, questões atinentes exclusivamente à pessoa de um dos sócios - tais como morte, incapacidade ou mesmo renúncia, no caso de sociedade por prazo indeterminado - continuavam expressamente a ensejar a dissolução da sociedade (artigo 1.399).

O Decreto 3.709/19, sempre lembrado pelo seu laconismo, não foi além de reconhecer a possibilidade de exclusão do sócio remisso (artigo $7^{\mathrm{a}}$ ) e estabelecer o pagamento de haveres do sócio que exercesse o direito de recesso com base no último balanço aprovado (artigo 15); infeliz critério este que, lamentavelmente, seria por vezes aplicado em matéria de exclusão, por via de analogia, até que fosse finalmente repelido pela jurisprudência. Talvez ao menos em parte motivada pela injustiça de tal critério, a doutrina e a jurisprudência entenderam que o estabelecimento do direito de recesso não implicava derrogação do direito ao pedido de dissolução da sociedade ${ }^{85}$.

Em peculiar opção de técnica legislativa, coube ao Código de Processo Civil de 1939, por meio de seu Título XXXVIII, artigos 655 a 674, disciplinar o procedimento de dissolução e liquidação das sociedades. Tais disposições se tornariam importantes para a exclusão de sócio, tanto pela questão de o desenvolvimento do instituto no Brasil ter sido fortemente associado à doutrina da, assim chamada, “dissolução parcial”, quanto pelo fato de a vigência dos artigos em questão ter sido expressamente ressalvada e preservada pela lei que promulgou o Código de Processo Civil atualmente em vigor. Merece destaque entre os dispositivos do Código de 1939, o artigo 668 que reconhecia a possibilidade de apuração de haveres exclusivamente em relação à participação do sócio falecido, em caso de continuação da sociedade.

\footnotetext{
85 “Ao invés do exercício do direito de retirada, fundado na norma do art. 15 do Dec. 3.708/19, o qual se resolve, em regra, com o reembolso das quotas conforme contratualmente estipulado ou como ordena o decreto, '...na proporção do último balanço aprovado...', o sócio dissidente recorre ao pedido da dissolução, terminando por receber seus haveres conforme verificação física e contábil dos bens que compõem o patrimônio social.” in V. FRANCO, Dissolução Parcial e Recesso nas Sociedades por Quotas de Responsabilidade Limitada, p. 19.
} 
No ano de 1945, o Decreto-Lei $n^{0} 7.661 / 45$, por meio de seu artigo 48, estabeleceu regras para a exclusão e arrecadação dos haveres de sócios falidos, afastando a hipótese de necessária dissolução da sociedade. Em relevante passo no sentido de consolidação do princípio da preservação da empresa, a segunda parte do parágrafo $2^{\circ}$, do artigo 335 do Código Comercial de 1850 restou, dessa forma, derrogada ${ }^{86}$.

Em torno da metade do século XX, iniciou-se o debate em torno da possibilidade de exclusão de sócios sem prévia e expressa cláusula no contrato social, o qual levaria à segunda grande reviravolta no regime do direito de exclusão dentro do ordenamento brasileiro. O desenvolvimento das teses que eventualmente culminariam na aceitação da exclusão não amparada por cláusula expressa esteve sempre estreitamente associado à doutrina da denominada “dissolução parcial”.

Em Direito Societário, a dissolução strictu sensu significa uma alteração reversível na situação jurídica da sociedade que marca o ingresso desta última no estado de liquidação. Ocorre, assim, uma substituição de seu objeto social original - a exploração de uma dada atividade econômica - pelas medidas necessárias à ultimação de seus negócios, satisfação de seus credores e partilha de excedente patrimonial entre os sócios. Em sentido amplo, porém ainda assim técnico, a dissolução pode ser compreendida como a soma dos procedimentos que conduzem à extinção da sociedade ${ }^{87}$.

A dissolução parcial não se subsume nem a um nem a outro conceito, daí a razão para a expressão ser frequentemente objeto de crítica por alguns estudiosos ${ }^{88}$, apesar de seu uso amplo e corriqueiro. Em apertada síntese, pode-se dizer que a tese da dissolução parcial foi mais uma das estratégias adotadas pela doutrina e pela jurisprudência brasileiras para afastar a aplicação de algumas das mais indesejáveis soluções prescritas pelas obsoletas e inadequadas normas de Direito Societário do Código Comercial de 1850.

Uma vez que, como mencionado anteriormente, o artigo 335, parágrafo $5^{\circ}$, do antigo Código assegurava a qualquer sócio a possibilidade de solicitar, sem necessidade de justa causa, a dissolução de sociedade constituída por prazo indeterminado, propôs-se como

\footnotetext{
${ }^{86}$ H. ESTRELLA, Apuração dos Haveres de Sócio, p. 43.

${ }^{87}$ M. PENTEADO, Dissolução e Liquidação de Sociedades, p. 17-18.

${ }^{88}$ Por exemplo: M. REALE, A Exclusão de Sócio das Sociedades e o Registro do Comércio, p. $288 . \mathrm{H}$. ESTRELLA, Apuração dos Haveres de Sócio, p. 95-96.
} 
alternativa menos gravosa a continuação da sociedade e o término apenas do vínculo entre esta e o sócio que pleiteava o encerramento de suas atividades.

A admissibilidade jurídica de tal solução intermediária, contudo, exigia a preservação dos direitos e interesses do sócio que exercia uma prerrogativa potestativa, atribuída expressamente pela lei. Era, portanto, necessário igualar - ao menos sob a perspectiva de tal sócio - as conseqüências econômicas da dissolução e da “dissolução parcial” ${ }^{89}$. É por tal razão que, por exemplo, prevaleceram durante longo tempo em nosso sistema as idéias de que os haveres do sócio que se retirava deveriam ser calculados com os mesmos critérios aplicados à liquidação da sociedade e que não poderiam ser pagos de forma parcelada $^{90}$.

O uso da expressão “dissolução parcial” tornou-se tão recorrente que acabou por compreender todas as hipóteses de perda do status de sócio conjugada com a continuação da sociedade. Fez-se necessário, assim, estabelecer uma distinção entre a dissolução parcial latu sensu, correspondente à mencionada acepção ampla do termo, e a dissolução parcial strictu sensu, que indica a retirada voluntária e imotivada (denúncia vazia) do sócio na sociedade constituída por prazo indeterminado ${ }^{91}$.

Egberto de Lacerda Teixeira exerceria um papel pioneiro e fundamental na aceitação da exclusão de sócios não amparada por cláusula expressa do contrato social. Em obra de 1956, após reconhecer o caráter então minoritário da posição que defendia ${ }^{92}$, o ilustre

89 “...se se acolhe a dissolução parcial, isto implica que, por essa dissolução, o sócio dissidente sai da sociedade, como sairia se houvesse dissolução total. Apenas a diferença entre ambas as soluções é com relação aos demais sócios, que, se fosse total, não poderiam continuar na sociedade, que se teria extinguido. [...] Em se tratando, porém de dissolução parcial, em que ele se retira sem se utilizar dessa faculdade de retirada voluntária, entendo que aqui deverá aplicar-se a regra da dissolução total com referência a ele...” Exmo. Min. Moreira Alves, STF, Recurso Extraordinário nº 89.464, DJU 04/05/1979 .

90 “....admitir o parcelamento do valor de reembolso na dissolução parcial seria um 'não senso' tendo em vista aquela finalidade de garantir ao sócio um tratamento pelo menos igual àquele que teria caso se cuidasse de dissolução total.” in V. FRANCO, Dissolução Parcial e Recesso nas Sociedades por Quotas de Responsabilidade Limitada, p. 25-26.

${ }^{91}$ H. VERÇOSA, Curso de Direito Comercial, Vol. 2, p. 236.

92 “A exclusão ou é legal (artigos 289 e 317 do Código Comercial) ou é expressamente convencionada no pacto instucional. Não se admite a cláusula implícita de exclusão de sócios. Inclinamo-nos a crer que, em determinadas circunstâncias, mesmo em falta de previsão estatutária específica, poderão os sócios por maioria, por justa causa, decretar a exclusão ou eliminação do sócio faltoso.” (grifos no original) in E. TEIXEIRA, Das Sociedades por Quotas de Responsabilidade Limitada, p. 285-286. Confirmando a posição contrária da doutrina anterior: “....a idéia de que a exclusão forçada de sócio, exceção feita às duas hipóteses expressas, previstas no Código, só poderia dar-se mediante justa causa cláusula contatual que a autorizasse prevaleceu por muitos anos na doutrina nacional.” in L. LEÃES, Exclusão Extrajudicial de Sócio em Sociedade por Quotas, p. 87. 
jurista propôs interpretação (ainda mais) ampliativa do artigo 339 do Código Comercial de 1850, baseando-se precisamente na doutrina da dissolução parcial.

Segundo seu raciocínio, uma vez que se admitisse que desavenças entre os sócios ou violações reiteradas de deveres sociais por parte de qualquer um deles poderiam levar à inviabilidade das atividades desenvolvidas e, consequentemente, à própria dissolução da sociedade, sempre caberia admitir, nos mesmos termos, a exclusão do sócio faltoso e a continuidade da empresa pelos demais consócios ${ }^{93}$. Neste caso, o fundamento da exclusão já não seria mais o princípio da liberdade contratual, posto em prática na forma de cláusula expressa de exclusão, mas a causa justificada, mencionada pelo artigo 339 do Código Comercial e, portanto - na visão do autor - implícita na convenção societária.

Egberto de Lacerda Teixeira salientava ainda que todos os sócios estariam cientes, desde o princípio dos vínculos societários, que suas atitudes incompatíveis com o desenvolvimento da empresa poderiam ensejar a dissolução strictu sensu (dissolução total) da sociedade. Logo, não caberia ao sócio infrator, que oferecesse justa causa para tanto, alegar surpresa ao ver ser aplicado contra si um remédio intermediário, mais brando do que a completa liquidação da sociedade, mesmo que a exclusão não estivesse explicitamente disciplinada no contrato social.

A linha de pensamento por trás da admissão da exclusão não amparada em cláusula expressa ou disposição legal ou contratual é perfeitamente válida - e seria, mais tarde, repetida e ulteriormente desenvolvida por Avelãs Nunes ${ }^{94}$, por exemplo - mas a sua aplicação prática deveria teoricamente estar sempre escorada em duas premissas: (i) os atos ou fatos capazes de conduzir à sociedade fossem imputáveis exclusivamente ao sócio que se buscava excluir e que, tratando-se de hipótese excepcional e não claramente prevista pela lei ou por cláusula expressa e (ii) o problema não pudesse ser contornado ou superado de outra maneira menos extrema.

\footnotetext{
93 "Se a doutrina e a jurisprudência, em falta de texto legal explícito, foram levadas a incluir, entre as razões de dissolução social, a desarmonia e a séria divergência entre os sócios, parece-nos lógico e eqüitativo que o mesmo se dê em relação à exclusão de sócio.” in E. TEIXEIRA, Das Sociedades por Quotas de Responsabilidade Limitada, p. 286.

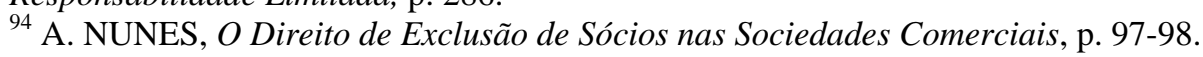


Dois fatores principais, contudo, contribuiriam para que a exclusão, ainda que não expressamente prevista pelo contrato social, fosse aplicada no Brasil de forma exagerada e sem as devidas cautelas. Em primeiro lugar, as normas relativas ao Registro do Comércio promulgadas ao longo do século XX buscaram de certa forma preencher o vácuo normativo deixado pela obsoleta e lacônica legislação societária e, ao fazê-lo, instituíram regimes e procedimentos de deliberação desequilibrados em favor dos sócios majoritários (com exceção das sociedades por ações, sempre regidas por lei própria). Ademais, a elevação da noção de affectio societatis a elemento essencial à própria manutenção do contrato de sociedade resultaria em uma corrosão da proteção que o fundamental requisito da justa causa ${ }^{95}$ poderia oferecer a um sócio, contra a arbitrariedade da maioria.

Em 1965, em substituição ao velho Decreto $\mathrm{n}^{0} 595$, de 1890 , foi promulgada a Lei $\mathrm{n}^{0}$ 4.726, relativa ao Registro do Comércio, cujo artigo 38, inciso V, vedava o arquivamento de instrumentos de alteração do contrato social de qualquer sociedade que não contivessem a assinatura de todos os sócios, ressalvada a hipótese de cláusula que autorizasse a deliberação majoritária. Em uma leitura apressada, tal disposição poderia ser avaliada como uma forma de proteção aos interesses dos sócios minoritários.

Entretanto, pode-se argumentar que a referida norma impôs às sociedades a escolha entre dois extremos procedimentais: (i) a atribuição aos minoritários de um poder de veto por meio da fixação de quorum qualificado ou na forma do inconveniente critério da unanimidade, ou (ii) a introdução de cláusula de deliberação majoritária, com o alheamento completo dos sócios minoritários das discussões e decisões relativas aos rumos da sociedade, dado que a lei não previa um regime assemblear de deliberação. Ainda que um sócio não tenha poder de impedir ou reverter isoladamente uma decisão da sociedade, é importante que possa acompanhar as deliberações (inclusive para poder prontamente solicitar a intervenção judicial contra eventuais abusos) e tenha oportunidades de se manifestar perante os demais.

Mesmo o registro em ata de um voto contrário vencido não é inócuo e pode ter relevantes conseqüências jurídicas como, por exemplo, afastar qualquer imputação de

95 “....a exigência de causa justificada para operar o afastamento compulsório de sócio prevaricador, constante da lei, é, na verdade, o contraponto lógico do direito do sócio de permanecer na sociedade, enquanto cumprir pontualmente os deveres sociais a que se comprometeu.” in L. LEÃES, Exclusão Extrajudicial de Sócio em Sociedade por Quotas, p. 86. 
responsabilidade ao sócio em questão baseada na alegação de assentimento tácito em relação a uma deliberação ilícita aprovada pela maioria.

$\mathrm{O}$ artigo 38, inciso $\mathrm{V}$, da Lei $\mathrm{n}^{\circ}$ 4.726, entretanto, suprimiu em termos práticos o regime assemblear e o direito ao debate nas sociedades então regidas pelo Código de Comércio de 1850. Na mesma esteira, a Lei $n^{\circ}$ 6.939/81, em seu artigo 6º inciso I, alínea “c”, reafirmou a impossibilidade de se solicitar o cancelamento de ato de exclusão de sócio - efetuada “nas hipóteses da lei” - com base na falta de assinatura de todos os sócios.

Em 16 de setembro de 1986, o Departamento Nacional do Registro do Comércio promulgou sua Instrução Normativa $\mathrm{n}^{0}$ 07. Já no preâmbulo do referido documento a premissa “b” fazia alusão aos artigos 289, 317 e 339, do Código Comercial de 1850, bem como a "reiteradas decisões judiciais", para defender a possibilidade de modificação do contrato social por deliberação majoritária, ainda que em face da ausência de expressa cláusula autorizadora.

Por meio do seu artigo $1^{\circ}$, o normativo em questão autorizou o arquivamento de atos de alteração de contrato social contendo apenas as assinaturas de sócios em número suficiente para formar maioria de capital, relativamente à hipótese de exclusão de sócio, mesmo que não houvesse cláusula permissiva no contrato social. O artigo $2^{\circ}$ da IN DNRC 07/86 impôs ainda como requisito do arquivamento da deliberação de exclusão de sócio a indicação expressa: (i) das causas de exclusão e (ii) dos fundamentos legais que haviam amparado tal decisão, além (iii) da destinação das quotas do sócio excluído.

A IN DNRC 29/91, que revogou a IN DNRC 07/86, seguiu essencialmente a mesma orientação desta última em matéria de exclusão de sócios, tendo simplesmente suprimido a exigência de indicação do fundamento legal sobre o qual se amparava a deliberação de exclusão (artigos 13 e 14).

No que tange à affectio societatis ${ }^{96}$, por outro lado, verifica-se que, sob égide de tal conceito, nossos tribunais passaram a atentar mais para a questão da desinteligência entre os sócios (a qual, inevitavelmente, estará presente em qualquer disputa relativa a processo

\footnotetext{
${ }^{96}$ Retoma-se a discussão do conceito de affectio societatis de maneira mais elaborada no Capítulo 5 deste trabalho, relativo às causas de exclusão.
} 
de exclusão, abusivo ou não) e menos para a investigação de condutas concretas de cada um deles. O conceito de justa causa, antes requisito essencial para a admissão da exclusão de sócio, foi sobremaneira enfraquecido, uma vez que parcialmente substituído pela evidência da existência de grave conflito entre os sócios, a qual se pode, no mais das vezes, ser colhida nos próprios autos ${ }^{97}$. Com efeito, a jurisprudência de nossos tribunais superiores chegou a afirmar que "basta a desinteligência entre os sócios para gerar a exclusão de um deles, independentemente de previsão contratual ou de pronunciamento judicial ${ }^{, 98}$.

A soma de todos esses elementos - exacerbação do princípio majoritário, enfraquecimento das garantias procedimentais nos processos decisórios da sociedade, além de uma sobrevalorização e leitura equivocada do conceito de affectio societatis - acabou por conferir ao instituto da exclusão de sócios, às vésperas da promulgação do Código Civil de 2002, feições de direito potestativo. Basta pensar na hipótese em que, antevendo futuras operações vantajosas para a sociedade, os sócios majoritários decidissem abusivamente excluir um minoritário, sem ter justa causa para tanto. Tal exclusão poderia ser levada a cabo por meio de documento preparado reservadamente entre tais sócios e sucessivamente levado à registro. Todos os requisitos formais ao arquivamento de tal ato poderiam ser facilmente contornados por meio de frases evasivas, apontando genericamente, por exemplo, o “rompimento da affectio societatis” como base para a deliberação de exclusão.

Ao eventualmente tentar reverter a situação em juízo, o sócio excluído correria sério risco de descobrir que a desinteligência entre os sócios - não causada por ele e da qual, absurdamente, a própria demanda judicial constituiria evidência - bastava para justificar a sua exclusão. Mais grave, contudo, é que a data de referência para a apuração de seus haveres seria aquela da execrável alteração contratual promovida por seus consócios, confirmando assim a eficácia constitutiva negativa que acabou por se atribuir a tal ato.

Causa certa perplexidade a constatação de que as principais disposições legais tomadas como base para tal estado das coisas (essencialmente, artigos 289, 317 e 339 do Código

\footnotetext{
${ }^{97}$ Como exemplo de que esta linha de pensamento ainda está presente na doutrina posterior à promulgação do Código Civil de 2002, pode-se citar: "É também justa causa para a exclusão a conduta do sócio que, mesmo sem caracterizar-se como violação da lei ou do contrato social, cria grave divergência entre eles, implicando a quebra da affectio societatis." (sem grifo no original) in M. CARVALHOSA, Comentários ao Código Civil - Parte Especial do Direito de Empresa, p. 311.

${ }^{98}$ STJ, Recurso Especial n 7.183 , DJU 16/10/91, Relator Exmo. Min. Monteiro de Barros.
} 
Comercial) eram as mesmas que vigoravam num período em que a aceitação da própria idéia de exclusão, ainda que amparada por expressa cláusula do Contrato Social, encontrara enorme resistência.

É de se cogitar se, ironicamente, a desenvoltura com que a doutrina soube ir além dos limites inicialmente colocados pela lei, trazendo a jurisprudência em sua esteira e viceversa, não é uma das responsáveis pelo imobilismo legislativo que cercou a sociedade limitada em geral, e o tema da exclusão de sócio, em particular, ao longo de todo o século XX. Se por um lado a atividade criativa de nossos juristas permitiu o convívio com normas vetustas e incompatíveis com a nova realidade econômica, por outro é forçoso reconhecer que esta forma de desenvolvimento de um instituto jurídico favorece a insegurança jurídica e aplicação de soluções não sistemáticas e, portanto, desencontradiças.

Muito do arcabouço doutrinário e jurisprudencial que se construiu em torno dos temas da exclusão de sócio e da denominada “dissolução parcial” é o resultado de esforços no sentido de compatibilizar normas obsoletas com uma nova realidade econômica. Produziram-se dessa forma interpretações extensivas da lei, senão mesmo contrárias a ela, que permitiram conciliar a retirada ou a exclusão de sócios com a preservação da sociedade. O louvável fruto desse longo trabalho, entretanto, não é necessariamente sistemático ou rigorosamente coerente e pode-se discutir se ele deve ser integralmente transposto, sem filtros ou ressalvas, para uma realidade normativa na qual grande parte dos obstáculos que tentou contornar, impostos por concepções individualistas do contrato de sociedade, já não existem mais.

Apesar de todas as críticas que recebeu, a grande maioria delas justificadas ${ }^{99}$, o Livro da Empresa do Código Civil de 2002 tem ao menos os inegáveis méritos de, especialmente com o disposto em seus artigos 1.030 e 1.085, finalmente trazer um mínimo de uniformidade para o instituto da exclusão e tentar restabelecer - ainda que com algum exagero - um certo equilíbrio em favor dos sócios minoritários.

${ }^{99}$ P. VIEIRA e A. REIS, As Sociedades Limitadas no Novo Código Civil - A Limitação do Direito de Contratar, p. 33. 


\section{FUNDAMENTO TELEOLÓGICO DA EXCLUSÃO DE SÓCIO}

A interpretação teleológica representa, quase sempre, um instrumento essencial para a busca da mais adequada aplicação das normas jurídicas. Uma interpretação meramente formal e mecânica do direito positivo - que desconsidere integralmente o escopo presumível de uma norma e o contexto histórico de sua promulgação e aplicação - encerra o risco de se obter um resultado diametralmente contrário ao interesse público e aos valores que inspiraram a criação da própria regra (summum ius, summa - saepe - iniuria). Consoante a clássica lição de Carlos Maximiliano, é a perspectiva teleológica que permite ao hermeneuta escapar da areia movediça da gramática ${ }^{1}$.

Especificamente em relação ao instituto da exclusão de sócios, pode-se argumentar que a interpretação teleológica possui uma importância particular e redobrada, em função de duas razões principais. Em primeiro lugar, a identificação do elemento teleológico por trás de cada uma das hipóteses de exclusão disciplinadas pelo Código Civil de 2002 representa o instrumento mais adequado para se esboçar uma distinção inicial entre (i) as situações de exclusão facultativa (do sócio remisso e daquele que comete qualquer outra falta grave) e (ii) os, assim chamados, casos de exclusão de pleno direito (falência do sócio e liquidação da quota para satisfação de dívida particular do sócio).

Por outro lado, no âmbito da exclusão facultativa de sócio, o método teleológico se demonstra igualmente relevante para a integração do sentido de expressões como "falta grave” (Código Civil de 2002, artigo 1.030) ou “atos de inegável gravidade” (artigo 1.085).

Com efeito, o legislador brasileiro acertadamente optou por não estabelecer um rol rígido de fatos ou eventos que podem ensejar a exclusão facultativa de um sócio. Tal estratégia confere a flexibilidade exigida pelo instituto, mas também acentua as dificuldades de interpretação do magistrado, no momento de sua aplicação. A lei prevê apenas duas hipóteses específicas de exclusão facultativa: a não integralização da quota social e a incapacidade superveniente. Mesmo no caso desta última, contudo, a aplicação do remédio da expulsão não pode ser automática e deve ter em conta os deveres atribuíveis ao sócio em cada situação concreta, confrontando-se sempre com o próprio sentido do instituto.

\footnotetext{
${ }^{1}$ C. MAXIMILIANO, Hermenêutica e Aplicação do Direito, p. 124.
} 


\subsection{A Exclusão de Pleno Direito}

A exclusão de pleno direito foi introduzida no ordenamento italiano (artigo 2.228, Código Civil Italiano de 1942) com o objetivo de afastar dúvidas de interpretação que, na vigência do Código Comercial de 1882, rondavam as questões da falência do sócio nas sociedades de pessoas e da possibilidade de liquidação da quota para satisfação de dívida particular do sócio ${ }^{2}$.

Inspiradas diretamente pela lei italiana e ora também consagradas pelo parágrafo único do artigo 1.030 de nosso próprio Código, tais hipóteses fogem completamente à tradição doutrinária e jurisprudencial brasileira em matéria de exclusão de sócio, que sempre se focou quase que exclusivamente na exclusão facultativa de quotista em função do inadimplemento de obrigações para com a sociedade.

É provavelmente por tal razão que a doutrina brasileira, tanto anterior como posteriormente à promulgação do Código Civil de 2002, dedicou pouquíssima atenção à exclusão de pleno direito, sem deter-se sobre as diferenças estruturais que apartam esse instituto da exclusão facultativa, foco principal do presente trabalho.

Nesse sentido, o objetivo deste sub-capítulo é justamente salientar as diferenças cruciais existentes, sob um ponto de vista teleológico, entre as hipóteses de expulsão ipso iure indicadas no parágrafo único do artigo 1.030 do Código Civil de 2002 e todos os demais casos de exclusão, nos quais o legislador atribuiu à maioria social a prerrogativa de manifestar-se previamente sobre a conveniência de se recorrer, ou não, a tal remédio extremo.

\subsubsection{A Liquidação da Quota em Função de Dívida Particular do Sócio}

O artigo 1.026 do Código Civil de 2002 teve claramente por objetivo sanar as dúvidas doutrinárias que, historicamente, sempre envolveram a questão da penhorabilidade das quotas no direito brasileiro. Anteriormente à promulgação da nova lei, duas forças principais e mutuamente contraditórias orientavam o debate sobre o tema. De um lado,

\footnotetext{
${ }^{2}$ V. BUONOCORE, G. CASTELLANO, R. COSTI, Società di Persone, p. 1132.
} 
verificava-se a necessidade de proteção dos interesses dos credores, com a reafirmação do princípio (consagrado pelo artigo 591 do Código de Processo Civil) de que o devedor responde por seus débitos com todo o seu patrimônio, salvo as exceções expressas previstas em lei (por exemplo, o bem de família). De outro, argumentava-se a inadequação da solução de, por meio a penhora das quotas, permitir que um absoluto estranho ingressasse no quadro de sócios da sociedade por quotas de responsabilidade limitada, que a despeito de seu caráter híbrido seria fortemente marcada pelo elemento do intuitu personae.

O Código de Processo Civil de 1973, em sua redação original, procurou contornar a questão instituindo, como alternativa, a possibilidade de se consumar a execução por meio de usufruto sobre o quinhão de empresa, nos termos do antigo artigo 720. Todavia, ao não excepcionar expressamente a quota social da incidência do artigo 591 do mesmo diploma, deixou substancialmente o problema em aberto $^{3}$.

Nesse sentido, o legislador de 2002 buscou inspiração direta no artigo 2.270 do Código Civil Italiano, ao determinar, por força do artigo 2.026 do novo Código, que o (i) o sócio responde por suas dívidas particulares não apenas com os lucros líquidos e outros valores distribuídos pela sociedade, mas com o próprio núcleo de sua participação no capital, e (ii) em respeito ao caráter pessoal das sociedades de pessoas, presente também na híbrida sociedade limitada brasileira, as quotas do sócio devedor não podem ser arrematadas ou adjudicadas por terceiro, mas devem ser liquidadas e o respectivo (e eventual) saldo deve ser colocado à disposição dos credores.

Tal solução permitiu a superação das incertezas anteriormente existentes em relação à matéria e tem o mérito de impedir a sociedade de artificialmente reter lucros e ganhos com o objetivo de prejudicar os credores particulares dos sócios. Além disso, as disposições do artigo 1.026 permitem ao credor ter acesso imediato ao investimento principal do sócio devedor, sem ter de se esgrimar com o antigo conceito de "fundos líquidos” previsto no artigo 292 do Código Comercial de 1850.

\footnotetext{
${ }^{3}$ J. LUCENA, Das Sociedades Limitadas, p. 369.
} 
Todavia, é igualmente inegável que a aplicação da nova norma representa um grave dano para a integridade do patrimônio social, que passa a estar sujeito às vicissitudes e aos infortúnios pessoais dos sócios. A apuração e o pagamento dos haveres do sócio devedor exigirão, na maioria dos casos, a alienação de ativos da sociedade e podem colocar a própria existência desta última em risco ${ }^{4}$.

Não se pode, de qualquer forma, afirmar que o artigo 1.026 não esboce qualquer preocupação no sentido de resguardar a sociedade. De fato, reiterando conceito já presente no mencionado artigo 292 do Código Comercial de 1850, a nova lei estabelece que a execução de dívida particular do sócio apenas pode recair sobre a sua quota social na hipótese em que se possa demonstrar a insuficiência de outros bens do devedor (ou, na linguagem do antigo Código Comercial, “outros bens desembargados”).

A inspiração italiana para o atual regime brasileiro de liquidação da quota, na hipótese de execução de dívida particular do sócio, não se limita, porém, ao artigo 1.026. Com efeito, o parágrafo único do artigo 1.030 do Código Civil de 2002 representa uma transposição quase literal do artigo 2.288 do Código Civil peninsular de 1942. O dispositivo em questão, sempre à luz do quanto dispõe a lei italiana, qualifica não apenas a liquidação da quota, como também falência do sócio, como hipóteses de exclusão de pleno direito.

No sistema brasileiro, as normas em questão estão contidas no capítulo dedicado às sociedades simples, mas (até a reforma do Código de Processo Civil introduzida pela Lei Federal $n^{0}$ 11.382/06) aplicavam-se à sociedade limitada, por força da ressalva expressa e remissão ao artigo 1.030, contidas no artigo 1.085. Paradoxalmente, o mesmo não se verifica no Direito Italiano, onde a liquidação da quota da società a responsabilità limitata está inteiramente disciplinada no artigo 2.471 do Código Civil de 1942 e não se sujeita, nem mesmo por via analógica, ao disposto nos artigos 2.270 e 2.288.

\footnotetext{
4 “....a liquidação compulsória da quota do devedor poderá levar a própria sociedade à dissolução, caso venha a revelar-se insustentável a sua situação como resultado da venda de bens de seu ativo para o pagamento do credor particular do sócio. Isto representará efeito negativo bastante amplo, como o desaparecimento compulsório de uma unidade produtiva, levando à perda da fonte de subsistência dos demais sócios e dos empregados da sociedade. Indiretamente, surgirá prejuízo também para os fornecedores desta, que perderão um cliente.” in H. VERÇOSA, Curso de Direito Comercial, vol. 2, p. 423.
} 
De qualquer modo, é importante assinalar que há razões para crer que a intenção do legislador brasileiro, com a referência expressa do parágrafo único do artigo 1.030 do Código Civil de 2002 ao artigo 1.026 do mesmo diploma, não foi estabelecer uma hipótese autônoma de exclusão, tal como se verifica em relação à falência do quotista, mas simplesmente confirmar a perda do status socii na hipótese de liquidação total da participação societária. Existem, de fato, duas interpretações possíveis para o parágrafo único do artigo 1.030, quando combinado com o artigo 1.026, e apenas uma delas permitiria efetivamente classificar a hipótese em questão como uma situação de exclusão do sócio.

De acordo com a primeira de tais interpretações, de natureza rígida e literal, sempre que seja necessário atingir a participação societária de um sócio para saldar uma dívida particular deste último, todas suas quotas devem ser liquidadas (ou a integralidade de sua única quota, conforme o caso), mesmo que o valor total da dívida seja inferior ao montante arrecadado com a apuração de seus haveres.

Essa é a visão da doutrina italiana mais tradicional e conservadora, que entendia que a exclusão do sócio não era conseqüência da liquidação de sua participação, mas simplesmente uma causa desta última ${ }^{5}$. Ou seja, de acordo com tal linha de pensamento, a mera necessidade de alcançar a quota do sócio para a satisfação de um credor pessoal, justificaria a automática perda do status socii, independentemente de qualquer proporção entre o montante da dívida e o valor da participação. Essa é a única linha de interpretação que permitiria classificar a liquidação da quota como uma verdadeira hipótese de exclusão do sócio.

A outra interpretação possível, de natureza sistemática, é a de que o parágrafo único do artigo 1.030 aplica-se à liquidação da quota em razão de débito particular do sócio apenas nos casos em que a dívida executada seja igual ou superior ao valor dos haveres apurados e, consequentemente, seja inevitável a liquidação total da respectiva participação societária.

\footnotetext{
${ }^{5}$ M. PERRINO, Le Tecniche di Esclusione del Socio dalla Società, p. 220.
} 
As diferenças práticas resultantes da aplicação de uma ou de outra tese são drásticas. Basta tomar em consideração um hipotético cenário em que o titular de cem quotas ${ }^{6}$ de uma sociedade limitada, cada uma com valor nominal individual de R\$1.000,00, e valor econômico total, verificado em apuração de haveres equivalente a R\$ 200.000,00, seja executado por uma dívida com montante de R\$1.000,00. Sem êxito em suas tentativas de localizar outros bens do devedor aptos a satisfazer o crédito em questão, o credor recorre a quanto disposto no parágrafo único do artigo 1.026 do Código Civil de 2002, solicitando a liquidação da participação do quotista.

De acordo com a interpretação literal e mais antiga, caberia, na hipótese mencionada acima, liquidar totalmente a participação do sócio devedor, pelo simples fato de ser necessário agredir o patrimônio social para sanar sua dívida particular, independentemente da desproporção entre o montante do débito e o valor econômico das quotas. Em tal caso, o valor de R\$ 1.000,00 seria colocado à disposição do credor e a quantia excedente, correspondente a R\$199.000,00, transferida ao sócio excluído.

A despeito do fato de uma mera fração da participação do sócio (in casu, a metade de uma quota) bastar para a satisfação da dívida, nos termos literais do parágrafo único do artigo 1.030, a apuração de seus haveres ensejaria sua exclusão de pleno direito, ou seja, uma expulsão automática e não sujeita a quaisquer formalidades, tampouco condicionada à vontade dos consócios remanescentes.

A prevalência de tal interpretação literal traria danos principalmente para a própria sociedade, com evidentes reflexos sobre a atividade econômica por ela desenvolvida. De fato, como recorda Giuseppe Bollino, para o sócio excluído tratar-se-ia de uma solução quase neutra, ao menos sob um ponto de vista patrimonial ${ }^{7}$. No momento anterior à

\footnotetext{
${ }^{6}$ Não teria nenhum impacto relevante sobre o raciocínio o fato de se tomar como premissa que cada sócio tenha uma única quota, tal como originalmente se usava no âmbito das sociedades de pessoas, ao invés de se supor que sua participação seja representada por múltiplas quotas de igual valor nominal (técnica emprestada das sociedades por ações). Em tal caso, a principal diferença é que seria necessária a redução do valor da única quota do sócio, na hipótese de prevalência da interpretação sistemática, com liquidação apenas parcial da participação do sócio. Adota-se, no exemplo, a multiplicidade de quotas apenas porque expressa melhor a realidade atual da vasta maioria das sociedades limitadas. A respeito da pluralidade de quotas no ordenamento brasileiro: E. TEIXEIRA, Das Sociedades por Quotas de Responsabilidade Limitada, p. 102. 7 “...vva tenuto presente allorché si esamina la fattispecie di cui al $2^{\circ}$ comma dell’art. 2288 c.c. è che in caso di aggressione della quota sociale da parte del creditore particolare del socio, il 'soggetto passivo' di tale aggressione, il soggetto cioè che ne se subisce le conseguenze più dannose non è il socio, bensì la società.” in G. BOLLINO, Le Cause di Esclusione del Socio nelle Società di Persone e nelle Cooperative, parte I, p. 405.
} 
exclusão, o devedor era titular de uma participação societária, mas tinha contra si uma dívida em aberto. Na fase seguinte, passa a dispor do saldo líquido existente entre ambas as posições patrimoniais. Sob a ótica do credor, a seu turno, uma vez devidamente quitada a dívida, seria irrelevante o destino do valor da participação que sobeja. Para a sociedade, por outro lado, a exclusão de pleno direito em função de execução de uma dívida com saldo inferior aos haveres totais do excluendo representaria uma descapitalização inesperada, extemporânea e, acima de tudo, desnecessária. Tratar-se-ia de uma ampliação ilógica dos danos causados pela necessidade de satisfazer os credores particulares do sócio.

Nesse sentido, parece muito mais razoável entender que a remissão expressa do parágrafo único do artigo 1.030 ao artigo 1.026 seja aplicável, única e exclusivamente, nos casos em que o montante da dívida executada iguale ou supere o valor dos haveres apurados. Ou seja, a participação de um sócio seria liquidada, sempre que possível, de forma meramente parcial, exclusivamente na medida necessária para saldar sua dívida particular. Assim, a perda do status socii teria lugar apenas na hipótese em que fosse inevitável empregar todo o montante dos seus haveres na satisfação do credor particular do quotista.

Tornando ao exemplo anterior, apenas a metade de uma quota seria liquidada e bastaria para a plena satisfação do credor particular do sócio. Para a sociedade, a perda patrimonial se limitaria ao valor da dívida executada, in casu R\$ 1.000,00. O sócio devedor sofreria uma pequena redução de sua participação e não receberia qualquer saldo líquido em dinheiro ${ }^{8}$.

De acordo com esta segunda linha de interpretação, o uso da expressão “de pleno direito excluído”, especificamente em relação ao artigo 1.026, seria uma mera referência atécnica e imprecisa à perda do status socii que lógica e inevitavelmente deriva da liquidação total da quota (a qual se verificaria, frise-se, quando e se necessário fosse) ${ }^{9}$. O real objetivo do legislador, segunda essa linha de interpretação, não teria sido o de instituir uma nova

\footnotetext{
8 “....la soddisfazione del creditore potrebbe avvenire con una liquidazione parziale della quota e, in tal caso, il socio potrebbe rimanere tale anche se con una partecipazione inferiore a quella precedentemente detenuta: in altri termini, se il valore liquidativo della quota è pari a mille ma il credito vantato è di cento, potrebbe essere sufficiente una liquidazione parziale della quota con conseguente riduzione proporzionale della percentuale di partecipazione del socio, senza necessariamente giungere alla sua esclusione dalla società." in G. BOLLINO, Le Cause di Esclusione del Socio nelle Società di Persone e nelle Cooperative, parte I, p. 404.

${ }^{9}$ O Professor Haroldo Malheiros Duclerc Verçosa, de fato, comenta que “...a exclusão do sócio não passa do resultado natural da liquidação de sua quota. Ao fim do processo, ele deixa, automaticamente, de ser sócio.” in H. VERÇOSA, Curso de Direito Comercial, vol. 2, p. 345.
} 
hipótese autônoma de expulsão ipso iure do sócio, em favor do interesse dos consócios ou dos credores, mas simplesmente o de confirmar a perda da qualidade de sócio do devedor, dada a incompatibilidade entre o esvaziamento completo de sua contribuição patrimonial e a sua permanência na sociedade.

Ao indicar que a perda do status de sócio ocorre de "pleno direito", a norma simplesmente esclareceria que, independentemente de qualquer outra formalidade, após a liquidação total de sua participação, não caberia mais ao devedor exercer qualquer uma das prerrogativas de sócio ou interferir com as atividades da sociedade. Em suma, de acordo com esta visão, a interpretação combinada do artigo 1.026 com o parágrafo único 1.030 resultaria em uma confirmação da possibilidade de expropriação da participação societária, ou seja, do fato de que a quota pode ser agredida para satisfazer o credor particular, e não em uma expulsão propriamente dita.

Esta segunda interpretação parece mais consoante à intenção do legislador de preservar o patrimônio da sociedade, objetivo que se revela em determinação contida no próprio artigo 1.026, que condiciona a agressão ao patrimônio social à verificação da inexistência de outros bens disponíveis do sócio devedor. Além disso, está em linha com o princípio geral do Processo Civil segundo o qual a execução de uma dívida deve ser processada da forma menos gravosa possível.

Cumpre reconhecer que a liquidação parcial das quotas (ou quota) do sócio devedor, ainda que menos drástica do que a solução propugnada pela interpretação literal, representa de qualquer forma um dano extemporâneo à integridade do patrimônio social, que em muitos casos pode igualmente ter como conseqüência a inviabilidade econômica da empresa.

Tal hipótese guarda grande semelhança com os casos de evicção do bem ou insolvabilidade do crédito conferidos ao capital da sociedade, previstos pelo artigo 1.005 do Código Civil de 2002. De fato, como em tais situações, é razoável que o sócio devedor seja responsabilizado pelos danos, inclusive os lucros cessantes, derivados da descapitalização extemporânea da sociedade, que provocou ou permitiu que ocorresse. Uma vez que a liquidação parcial da participação apenas ocorrerá caso o sócio em questão não tenha outros bens disponíveis, certamente não será fácil para a sociedade obter seu 
justo ressarcimento. Mas a execução do crédito indenizatório poderia, por exemplo, ser efetuada por meio da compensação contra dividendos futuros atribuíveis a tal sócio.

É essencial recordar, contudo, que a Lei Federal $n^{0}$ 11.382/06 recentemente alterou, especificamente em relação às sociedades empresárias, a disciplina do artigo 1.026 do Código Civil de 2002, reconhecendo expressamente - por meio da nova redação dada ao artigo 655, inciso IV, Código de Processo Civil - a possibilidade de penhora da quota social para a satisfação do credor particular ${ }^{10}$.

Além disso, o parágrafo $4^{\circ}$, do novo artigo 685-A do Código de Processo Civil prevê, outrossim, que os sócios terão preferência na aquisição da participação societária penhorada, sempre que o credor-exeqüente não seja um quotista. Tal disposição confirma o entendimento de que, no novo regime, é a própria quota da sociedade empresária o objeto da execução e não os haveres atribuíveis ao sócio devedor como resultado da liquidação de sua participação.

Se não existisse a possibilidade concreta de um terceiro, estranho à sociedade, tornar-se sócio - fato que apenas é possível se afastada a obrigatoriedade da apuração, liquidação e pagamento dos haveres - não haveria razão para se assegurar o direito de preferência aos sócios remanescentes. Em suma, as novas regras processuais parecem afastar a incidência do artigo 1.026 do Código Civil de 2002 às sociedades limitadas, relegando a aplicação de tais dispositivos às sociedades simples e contribuindo para a tese de que a intenção do legislador não foi instituir uma efetiva hipótese de exclusão do sócio, mas simplesmente tutelar a satisfação de seus credores particulares.

De qualquer modo, mesmo antes da promulgação da Lei Federal $n^{\circ} 11.382 / 06$, já se argumentava que, em certas hipóteses, seria possível afastar a aplicação do artigo 1.026 do Código Civil de 2002 em relação a sociedades limitadas que reunissem determinadas características de sociedades de capitais. De fato, a idéia principal por trás do complexo mecanismo de definição das normas aplicáveis à sociedade limitada (artigo 1.053,

\footnotetext{
10 "O dispositivo, contudo, vai além, consagrando vencedora diretriz doutrinária e jurisprudencial quanto à penhorabilidade de ações e quotas mesmo quando não tenham cotação em bolsa e mesmo que constitutivas de sociedade que, pela sua própria razão de ser, pressupõem a affectio societatis entre seus componentes." in L. WAMBIER, T. WAMBIER, M. MEDINA, Breves Comentários à Nova Sistemática Processual Civil, vol. 3, p. 108.
} 
parágrafo único) é permitir que os sócios tenham a flexibilidade de aproximar a disciplina da sociedade, em cada caso concreto, mais às normas relativas às sociedades de pessoas ou mais aos princípios aplicáveis às sociedades de capitais, de acordo com seus interesses e suas necessidades.

Nesse sentido, Syllas Tozzini e Renato Berger, em comentários de atualização à clássica obra de Egberto Lacerda Teixeira sobre a sociedade por quotas de responsabilidade limitada, já defendiam - anteriormente à mais recente reforma do processo de execução - a idéia de que, nos casos em que o contrato social previsse a livre cessão de quotas (dado o caráter expressamente dispositivo do artigo 1.057 do Código Civil de 2002), não se aplicaria a solução prevista pelo artigo 1.026, uma vez que a dívida particular do sócio poderia ser saldada por meio da simples transferência de sua participação a um terceiro, sem a liquidação das respectivas quotas e, portanto, sem dano ao patrimônio social ${ }^{11}$.

De fato, ao autorizar a livre cessão de quotas, os sócios reconheceriam que as qualidades pessoais de cada quotista não são essenciais ao desenvolvimento das atividades da sociedade. Assim, naquele específico arranjo societário, o intuitu personae teria uma importância apenas secundária e não poderia ser colocado como obstáculo ao ingresso do terceiro no quadro de sócios.

Tal proposição provavelmente se inspira em tese construída anteriormente à promulgação do próprio Código Civil de 2002, no âmbito do longo debate existente no Brasil em matéria de penhorabilidade de quotas. De fato, já em 1948, o Tribunal de Justiça do antigo Distrito Federal teria afirmado que a quota seria penhorável apenas na hipótese em que o contrato social não estabelecesse restrições à sua transferência a terceiros ${ }^{12}$. Contudo, enquanto esta antiga interpretação representava uma imprópria invasão do Direto Processual pelo Direito Privado, a tese de Tozzini e Berger tem o mérito de não condicionar a satisfação dos credores a disposições contratuais com as quais jamais anuíram $^{13}$.

\footnotetext{
${ }^{11}$ E. TEIXEIRA, Da Sociedade por Quotas de Responsabilidade Limitada, p. 287.

${ }^{12}$ Decisão citada em voto vencedor do Exmo. Min. Xavier de Albuquerque, STF, Recurso Extraordinário n. 90.910-PR, DJU 14/11/1980.

${ }^{13}$ J. LUCENA, Das Sociedades Limitadas, p. 383.
} 
Efetivamente, de acordo com tal entendimento, o credor particular poderia sempre atacar a participação societária para a satisfação de seu crédito; o único elemento variável é o modo pelo qual se processa a execução. Caso o contrato social impusesse restrições à livre cessão de quotas, estas deveriam ser liquidadas nos termos do artigo 1.026, de modo que não restasse vulnerado o presumível intuitu personae existente naquela sociedade. Por outro lado, na hipótese em que o ato constitutivo autorizasse a livre cessão das quotas, estaria afastada a incidência do artigo 1.026 e a exclusão recairia sobre a própria participação societária (por meio da transferência da titularidade sobre esta última) e não sobre os haveres atribuíveis ao sócio devedor.

Contrário a tal entendimento, Waldecy Lucena afirmou que o artigo 1.026 seria aplicável mesmo em relação às sociedades limitadas que tivessem expressamente adotado o regime das sociedades anônimas como disciplina supletiva, nos termos do parágrafo único do artigo 1.053. Isso porque, segundo o festejado autor, as normas atinentes às sociedades por ações seriam omissas em relação a esse ponto específico, sendo inevitável suprir a lacuna com as normas da sociedade simples ${ }^{14}$.

Com a devida vênia ao ilustre doutrinador, não parece possível concordar com todos os termos da interpretação por ele sugerida. Não se pode dizer que a lei acionária seja omissa em matéria de liquidação das ações para satisfação de um credor particular do acionista, simplesmente porque tal hipótese é incompatível com a própria natureza das sociedades por ações. A despeito da abolição das ações ao portador, a ação é um título e como tal pode circular $^{15}$. A lei processual determina que a execução de dívida deve preferencialmente recair sobre outros bens, mas - mesmo antes da última reforma legislativa - já previa expressamente que as ações (tal como, no regime atual, as quotas da sociedade empresária) podem ser objeto de penhora. Neste caso, altera-se a titularidade das ações, mas não ocorre a liquidação da participação societária e o patrimônio da sociedade resta inalterado.

Em resumo, tratava-se de uma posição intermediária entre o disposto no artigo 1.026 do Código Civil de 2002 e o regime estabelecido com a reforma do processo de execução. A solução proposta por Tozzini e Berger possuía como principal mérito a vantagem de consolidar o caráter híbrido da sociedade limitada, permitindo aos quotistas, por meio de

${ }^{14}$ J. LUCENA, Das Sociedades Limitadas, p. 384.

${ }^{15}$ E. TEIXEIRA, Das Sociedades por Quotas de Responsabilidade Limitada, p. 276. 
cláusula expressa no contrato social, a escolha entre o menor de dois males: (i) a agressão ao patrimônio social (típico das sociedades de pessoas) ou (ii) a admissão de um estranho no quadro se sócios (característico das sociedades de capitais); sujeitando, porém, em ambos os casos a totalidade participação societária à satisfação da dívida particular do sócio.

As novas normas aplicáveis ao processo de execução estabeleceram, todavia, uma solução mais rígida, aproximando a sociedade limitada ao regime da sociedade anônima. Tal posição está em linha com as disposições do artigo 2.471 do Código Civil Italiano, que disciplina a penhora de quota por dívida particular do sócio no âmbito das società $a$ responsabilità limitata, as quais são sabidamente classificadas como sociedades de capitais pelo ordenamento italiano. A principal diferença entre o regime italiano e a nova disciplina do artigo 655, inciso IV, do nosso Código de Processo Civil é que a norma estrangeira estende o direito de preferência na aquisição das quotas do devedor não somente aos sócios, mas a um terceiro de confiança destes últimos, expressamente indicado pelos quotistas remanescentes.

Ainda que a solução adotada pelo novo regime processual brasileiro seja mais rígida do que a interpretação construída por Tozzini e Berger e não tenha dado a devida atenção ao caráter híbrido da sociedade limitada brasileira, ela é certamente preferível em relação à necessária liquidação da quota, originalmente imposta pelo artigo 1.026 do Código Civil de 2002.

Importa recordar que, mesmo com a reforma do processo de execução, a tese proposta por Tozzini e Berger resta válida para as sociedades não empresárias - expressamente excluídas do âmbito de incidência do novo inciso IV, do artigo 655, do Código de Processo Civil -, as quais podem, inclusive, adotarem a forma de sociedade limitada, consoante o artigo 983 do Código Civil de 2002.

Para a presente análise, de qualquer forma, o ponto crucial é que, tanto antes quanto depois da reforma do processo de execução no Brasil, apenas é possível falar em exclusão de pleno direito do sócio caso se aceite uma interpretação literal e em grande parte inadequada do artigo 1.026. Contudo, a vontade do legislador (no sentido de mens legis) em tal caso parece ter sido simplesmente disciplinar as conseqüências da liquidação total da quota. 
Assim, não se trataria de uma hipótese de exclusão de pleno direito, mas simplesmente uma referência imprópria e não técnica à perda do status socii, que derivaria logicamente do esvaziamento absoluto de sua contribuição para a sociedade.

\subsubsection{A Exclusão do Sócio Falido}

Em matéria de falência do sócio, o Código Comercial de 1850 continha orientação extremamente individualista, ao determinar, nos termos do artigo 335, parágrafo 2, que a quebra de qualquer dos sócios acarretaria a dissolução total da sociedade.

Como já mencionado no Capítulo 1, o rigor e o caráter obsoleto de disposições como o artigo em questão, somados a um longo período de inércia legislativa, acabaram por inspirar a construção da doutrina da, assim chamada, “dissolução parcial”, por meio da qual, entre outros resultados, foi possível compatibilizar a satisfação dos credores pessoais do sócio falido com a continuidade da sociedade, em homenagem ao princípio da preservação da empresa.

Especificamente em relação à falência, a legislação absorveu os avanços sugeridos pela doutrina e pela jurisprudência com a promulgação do Decreto-Lei $n^{0}$ 7.661/45, o qual já não mais determinava a dissolução da sociedade como conseqüência automática da falência do sócio, mas simplesmente previa em seu artigo 48 a arrecadação dos haveres do falido em favor da massa, nos termos fixados no contrato social da respectiva sociedade. Na mesma linha, o artigo 123 da Lei Federal $n^{0}$ 11.101/05, determina atualmente a apuração dos haveres do sócio falido que seja “comanditário ou quotista”, na forma do respectivo contrato social.

A este respeito, o Código Civil de 2002 inovou substancialmente em relação ao regime anterior e, como no caso da liquidação de quotas para a satisfação de dívida particular do sócio, buscou inspiração direta no Código Civil Italiano de 1942, em particular no artigo 2.288 deste último. De fato, o parágrafo único do artigo 1.030 do Código Civil de 2002, prevê a exclusão “de pleno direito” do quotista que seja declarado falido.

Ocorre observar, preliminarmente, que tal previsão não se confunde nem decorre necessariamente de outras cominações legais impostas ao falido, tais como o impedimento 
para o exercício de atividades empresariais (artigo 102 da Lei Federal $\mathrm{n}^{\circ}$ 11.101/05) ou a indisponibilidade dos próprios bens.

Em relação à inabilitação para o exercício de atividade empresarial, cumpre recordar que a maioria das sociedades, inclusive a sociedade limitada, possui, no ordenamento brasileiro, personalidade jurídica própria, distinta daquela de seus sócios. Assim, a capacidade do sócio falido para realizar determinada atividade não se confunde com a da sociedade, efetiva titular da empresa. Desse modo, a inabilitação pessoal do primeiro não deveria, em princípio, atingir as atividades da segunda ${ }^{16}$.

Por outro lado, não se pode tampouco dizer que a exclusão do sócio falido seja um simples desdobramento da indisponibilidade de seus bens ou da perda da capacidade de administrálos. Tais medidas conservativas impedem o sócio de alienar sua participação e de exercer algumas prerrogativas que normalmente decorrem da relação de propriedade, mas não implicam em si uma sumária e instantânea expropriação.

É necessário, outrossim, salientar que a exclusão do sócio falido não se confunde com a hipótese de liquidação total da quota nem pode ser reduzida a esta última. Contrariamente àquela, a exclusão do sócio falido não comporta interpretações restritivas ou intermediárias, que possam mitigar o excessivo rigor da norma ${ }^{17}$.

De fato, como recorda Giuseppe Bollino, a declaração de falência, de um lado, e a apuração de haveres e sua arrecadação em favor da massa falida, de outro, não coincidem ou se identificam, seja sob um ponto de vista cronológico, seja sob uma perspectiva conceitual $^{18}$. No momento de declaração da falência (no qual, segundo o parágrafo único do artigo 1.030, já se verifica a exclusão de pleno direito), não é ainda possível determinar

\footnotetext{
16 "Se, por alguma razão, for declarada a falência deste [o sócio] como empresário, deseja o legislador do NCC que tal efeito o atinja na qualidade de sócio de uma sociedade simples. Ora, mesmo falida, uma pessoa não perde os direitos que a este título lhe são conferidos pela CF. Como resultado da sentença declaratória da falência, fica o falido proibido de comerciar, mas nada o impede de continuar como sócio de uma sociedade qualquer, inclusive uma sociedade simples. Como sócio ele não estará exercendo o comércio que lhe é proibido, pois o empresário é a sociedade, e não o sócio...” in H. VERÇOSA, Curso de Direito Comercial, vol. 2, p. 346.

17 "L'esclusione automatica del socio fallito è disposta dall'art. 2288 con tale perentorietà da rendere in apparenza inutile o non fruttuosa qualsiasi interpretazione riduttiva...” in V. BUONOCORE, G. CASTELLANO, R. COSTI, Società di Persone, p. 1132.

${ }^{18}$ G. BOLLINO, Le Cause di Esclusione del Socio nelle Società di Persone e nelle Cooperative, parte I, p. 391-392.
} 
o valor dos haveres atribuíveis ao sócio excluendo falido em função da liquidação de sua participação. Nos termos da lei, o falido perde o status de sócio no ato de declaração da falência, antes mesmo que se possa dar início à apuração de seus haveres. Em tal momento, sequer é possível afastar as hipóteses de que o valor da participação em questão exceda o montante do passivo falimentar ou de que simplesmente não exista saldo positivo em favor do excluendo, que possa ser transferido à massa falida.

Desse modo, a exclusão de pleno direito do sócio falido não pode ser entendida como conseqüência natural ou mero desdobramento lógico da necessidade de arrecadar as quotas para a futura satisfação de seus credores particulares. Tais procedimentos poderiam ter lugar independentemente da expulsão do sócio, já no momento da declaração de falência. Trata-se, portanto, de uma hipótese autônoma de exclusão.

Além de não se confundir com a hipótese de liquidação da quota, a exclusão do sócio falido diferencia-se de todos os demais casos de exclusão disciplinados pelo Código Civil de 2002. O sentido do parágrafo único do artigo 1.030 parece efetivamente repousar em objetivos normativos muito distintos daqueles que orientam a disciplina da expulsão facultativa de sócios, tal como prevista nos artigos 1.004, 1.030 caput e 1.085 do Código Civil de 2002.

Com efeito, os traços principais do regime da exclusão ipso iure impedem que ele seja agrupado sob o fundamento teleológico comum da defesa da atividade ou fim social, impondo (como se argumenta no próximo capítulo) o reconhecimento do fato que as hipóteses de exclusão de sócio de pleno direito possuem, também, um fundamento dogmático distinto.

O principal elemento que, no regime do Código Civil de 2002, diferencia a exclusão de pleno direito das hipóteses de expulsão facultativa é precisamente o automatismo e a natureza cogente que caracterizam a aplicação do instituto na primeira, ausente nos casos de exclusão do sócio inadimplente em face da sociedade.

Na exclusão do sócio remisso (artigo 1.004), na exclusão judicial por justa causa (artigo 1.030 caput) ou na exclusão extrajudicial por justa causa (artigo 1.085), a aplicação ou não do remédio extremo da expulsão é sempre sujeita à vontade da sociedade, apurada por 
meio de deliberação dos sócios adimplentes. Em tais casos, o legislador atribui aos demais sócios a faculdade de livremente apreciar qual seja a hipótese menos danosa para a sociedade, a permanência do sócio inadimplente ou a descapitalização resultante do pagamento dos haveres deste último.

Tal possibilidade de avaliar a conveniência da expulsão não está presente na exclusão de pleno direito, que se opera e produz efeitos independentemente de qualquer formalidade ou manifestação específica dos sócios ${ }^{19}$. De fato, a redação do parágrafo único do artigo 1.030 se reveste de todos os traços de um comando cogente do legislador, que não pode ser derrogado ou repelido pela vontade das partes.

Uma vez verificada a falência do sócio, não cabe aos consócios ou à sociedade apreciar a oportunidade de sua exclusão, mas simplesmente constatar (prendere atto) que o falido não mais integra o quadro de sócios. Uma eventual deliberação contrária à exclusão seria inócua e uma decisão judicial sobre a matéria teria caráter meramente declaratório e não constitutivo negativo ${ }^{20}$.

Como salienta Giuseppe Bollino, que conduziu um dos mais profundos e detalhados estudos sobre a questão, a ausência de qualquer espaço para a avaliação da conveniência da exclusão do falido por parte da sociedade demonstra que a intenção do legislador, neste caso, não foi proteger o interesse particular dos sócios, nem se inspira diretamente no princípio da preservação da empresa ${ }^{21}$.

Poderia se argumentar, na tentativa de abrigar a exclusão de pleno direito sobre o fundamento teleológico da preservação da empresa, que o legislador elevou a falência do sócio a uma causa de exclusão em função de um presumível impacto negativo que esta

\footnotetext{
19 “...esclusione di diritto, in cui cioè l'esclusione è conseguenza automatica del verificarsi di determinati fatti a carico del socio, senza necessità del ricorso all'autorità giudiziaria, né di una manifestazione di volontà sociale...” in M. PERRINO, Le Tecniche di Esclusione del Socio dalla Società, p. 74.

20 "nella fattispecie di cui all'art. 2288 c.c. lo scioglimento del rapporto sociale limitatamente al socio avviene automaticamente al solo verificarsi del presupposto previsto dalla legge senza che i rimanenti soci possano fare alcunché per impedire l'evento. Una loro eventuale decisione in merito avrebbe il valore di semplice presa d'atto." (sem grifo no original) in B. ACQUAS, C. LECIS, L'Esclusione del Socio nelle Società di Persone, p. 205.

21 “...né l'interesse dei soci né quello della massa fallimentare appaiono di per sé idonei, da soli, a giustificare l'esclusione di diritto del socio fallito; la ratio della norma andrà quindi ricercata su altro terreno." in G. BOLLINO, Le Cause di Esclusione del Socio nelle Società di Persone e nelle Cooperative, parte I, p. 394.
} 
poderia ter sobre a sociedade. Segundo essa visão, dada a "certeza” de que a falência do sócio representaria um dano à reputação e aos negócios da sociedade, a lei se anteciparia a uma decisão desta última e determinaria a exclusão automática do falido ${ }^{22}$. Tratar-se-ia, contudo, nos termos da precisa e aguda lição de Bollino, de um legislador extremamente paternalista e pré-capitalista. Por outro lado, não teria qualquer sentido pressupor o interesse dos consócios na exclusão na hipótese de falência e não fazê-lo em situações potencialmente mais vexatórias como, por exemplo, a condenação por crime grave ${ }^{23}$.

Além do mais, já se mencionou anteriormente como a necessidade de apurar e pagar os haveres do excluído representa uma descapitalização extemporânea, que pode inclusive inviabilizar a continuidade da atividade social. Se a intenção da norma fosse realmente resguardar a sociedade, não haveria razão pela qual a lei não assegurasse aos consócios o espaço para avaliar qual seria, em uma dada situação concreta, o menor de dois males: a perda de parte do patrimônio da sociedade ou o possível descrédito decorrente da existência de um quotista falido no quadro de sócios. Não há lógica em se dizer que o objetivo da lei foi impor um grave dano à sociedade justamente para protegê-la. Em suma, se a exclusão do sócio falido fosse instituída em favor da sociedade ou dos consócios, estes poderiam naturalmente renunciar a tal prerrogativa.

Desse modo, parece inevitável buscar o sentido da exclusão ipso iure do falido na tutela de outros interesses e situações. A tese mais plausível é a de que tal hipótese de expulsão visa, em termos gerais, (i) a punir o falido e (ii) a resguardar o interesse público no bom funcionamento da economia e na preservação do sistema de crédito. Em particular, a

${ }^{22}$ Em defesa de tal tese, Brunello Acquas afirma que: “...non sarebbe congruo mantenere un soggetto dichiarato fallito all'interno della compagine sociale sia perché non pare più in grado di fornire alcun utile apporto per il perseguimento dello scopo sociale sia per il discredito che inevitabilmente segue alla dichiarazione di fallimento.” in B. ACQUAS, C. LECIS, L'Esclusione del Socio nelle Società di Persone, p. 210.

23 “...la teoria secondo cui il legislatore avrebbe inteso tutelare i soci valutando autonomamente la gravità della situazione determinata dalla dichiarazione di fallimento di uno di essi non convince. Tralasciando, infatti, ogni considerazione su questa visione precapitalista di un legislatore paternalista che imporrebbe drastici ed autolesionistici rimedi (l'esclusione è sempre un fatto traumatico soprattutto per la società dal momento che ad esso consegue la necessità di smobilizzare una parte del patrimonio sociale ai fini della liquidazione della quota) allo scopo di preservare i soci da ulteriori possibili nefaste conseguenze, non si comprende perché mai nel caso il socio abbia subito una condanna penale - anche per un delitto particolarmente grave ed efferato - la sua esclusione dalla società sia solo eventuale, mentre in caso di fallimento la risoluzione del rapporto avverrà automaticamente.” in G. BOLLINO, Le Cause di Esclusione del Socio nelle Società di Persone e nelle Cooperative, parte I, p. 385. 
exclusão do falido contribuiria para (iii) proteger os seus credores particulares ${ }^{24}$. Apenas a tutela de questões de interesse público poderia, com efeito, explicar e justificar a invasão da esfera da autonomia privada dos sócios e da sociedade, que se verifica com a supressão da possibilidade de estes pactuarem uma resposta intermediária e mais amena para a falência do sócio ${ }^{25}$.

Um forte indício em favor da intenção punitiva da exclusão de pleno direito do sócio falido pode ser colhido na legislação italiana anterior ao Código Civil de 1942, que justamente previa, como uma sanção acessória à condenação por crime falimentar, exatamente a exclusão do falido de todas as sociedades de pessoas das quais fosse sócio ${ }^{26}$.

Em relação ao andamento do processo de falência, a exclusão do falido pode favorecer e acelerar a arrecadação dos bens do sócio em favor da massa falida ${ }^{27}$. De fato, em razão da natureza ipso iure de tal exclusão, a apuração dos haveres do sócio poderia se iniciar, teoricamente, já no momento em que a sociedade tome ciência da declaração de falência. Assim, não seria necessário aguardar qualquer específica solicitação do administrador judicial ou uma ordem do juízo da falência para dar início a tal procedimento.

Ademais, a exclusão de pleno falido tem o condão de desestimular a transferência indevida das atividades ou bens deste último para as sociedades das quais participe, servindo, portanto, como uma forma de coibir a fraude falimentar.

Naturalmente, não se busca defender ou justificar com tais argumentos a opção legislativa do ordenamento italiano, acriticamente reproduzida e transplantada pelo legislador brasileiro. O estabelecimento da exclusão de pleno direito do falido é, em muitos aspectos, uma decisão equivocada ${ }^{28}$. Trata-se de uma medida excessivamente rigorosa, em sentido contrário ao caráter pragmático do atual Direito Falimentar, que busca preservar a

\footnotetext{
${ }^{24}$ G. BOLLINO, Le Cause di Esclusione del Socio nelle Società di Persone e nelle Cooperative, parte I, p. 395.

${ }^{25}$ M. PERRINO, Le Tecniche di Esclusione del Socio dalla Società, p. 218-219.

${ }^{26}$ G. BOLLINO, Le Cause di Esclusione del Socio nelle Società di Persone e nelle Cooperative, parte I, p. 396-397.

27 "L'irrogazione di tale sanzione [exclusão] avrebbe poi numerosi riflessi vantaggiosi. Innanzi tutto essa consentirebbe di garantire, nella quasi totalità dei casi, che la procedura fallimentare acquisisca più rapidamente la quota di liquidazione spettante al socio escluso...” in G. BOLLINO, Le Cause di Esclusione del Socio nelle Società di Persone e nelle Cooperative, parte I, p. 395.

${ }^{28}$ H. VERÇOSA, Curso de Direito Comercial, vol. 2, p. 345-346.
} 
atividade empresária e não mais presume a desonestidade do falido, nem o vê como um párea. O objetivo da análise é simplesmente demonstrar o particularismo do fundamento teleológico desta hipótese específica de exclusão.

Em conclusão, pode-se afirmar que a expulsão do falido, contrariamente ao afastamento do sócio na hipótese de liquidação da quota para a satisfação de dívida particular, representa um efetivo e autônomo caso de exclusão estabelecido pela lei. Por outro lado, tal hipótese de exclusão se distingue de todos os casos de exclusão facultativa, por não compartilhar com estes últimos um fundamento teleológico comum. Enquanto a exclusão de pleno direito do falido se orienta pela defesa do interesse público, as hipóteses de exclusão facultativa parecem estar pautadas (como se argumenta adiante) pela defesa do interesse dos sócios e da sociedade.

\subsection{A Exclusão Facultativa}

\subsubsection{Exclusão e Preservação da Empresa}

Os artigos 1.004, 1.030 caput e 1.085 do Código Civil, disciplinam hipóteses em que a viabilidade da exclusão é condicionada a uma prévia deliberação dos consócios. Não se pode falar, em nenhum de tais casos, em decisão discricionária, uma vez que a expulsão deve estar sempre calcada em evento previsto na lei ou no contrato social. Existe, de qualquer modo, um nítido espaço para um juízo de conveniência por parte dos sócios, que podem avaliar livremente se a exclusão efetivamente representa, em cada caso concreto, a melhor solução para a sociedade. As hipóteses de exclusão facultativa se afastam, portanto, do rígido automatismo presente na exclusão de pleno direito.

O fato de se privilegiar a vontade dos sócios é um traço distintivo, que indica que a intenção do legislador, neste caso, foi tutelar prioritariamente os interesses da sociedade, e não os de terceiros ou da coletividade com um todo. Todavia, mesmo entre os sócios, a lei optou deliberadamente por favorecer a vontade de alguns quotistas em detrimento da posição e do interesse de outros.

Com efeito, em resposta ao longo amadurecimento histórico discutido no capítulo anterior, o ordenamento passou a proteger o grupo de sócios que propõem a continuidade da 
sociedade, em prejuízo do interesse individualista daquele que deseja sua dissolução total ou que age contra o interesse social ${ }^{29}$. A exclusão de sócio é, efetivamente, apenas uma parte do cenário mais amplo da admissão da resolução da sociedade limitadamente a um sócio.

O favorecimento do grupo de sócio que pretende continuar com a atividade empresarial não representa uma escolha (doutrinária e legislativa) óbvia ou neutra, mas que, ao contrário, desafiou os preceitos tradicionais do Direito das Obrigações e exigiu que o princípio da resolução contratual por inadimplemento se adaptasse às necessidades do Direito Societário. É evidente, portanto, que o desenvolvimento normativo em tal campo tenha sido impulsionado por um claro movente, a conservação da sociedade. Não que a sociedade represente por si só um valor ser resguardado pelo ordenamento. A conservação do ente societário se justifica apenas na medida em que este reveste juridicamente a atividade empresarial e com ela se entrelaça, e é exatamente aí que se encontra o principal elemento teleológico da exclusão facultativa por inadimplemento.

Os conceitos de empresa e de atividade empresária representam, efetivamente, uma chave de interpretação essencial para a compreensão desta modalidade de exclusão. Ao longo do debate sobre o sentido e sobre a natureza jurídica de tal instituto, muito se discutiu sobre quais seriam os interesses prevalentemente tutelados pela lei. Para alguns seria o interesse público $^{30}$, enquanto para outros seria o interesse privado dos sócios ${ }^{31}$. A introdução da idéia de preservação da empresa pode não permitir uma plena reconciliação entre ambas as esferas, mas ao menos demonstra que estas não estão em oposição diametral e em certa medida se sobrepõem e se complementam.

O interesse imediatamente tutelado pelo instituto da exclusão facultativa é inequivocamente o da sociedade, tanto que a lei reservou a esta última (por meio de deliberação da maioria social) a faculdade de, presentes os respectivos pressupostos,

\footnotetext{
29 "Mas os altos interêsses econômicos e sociais que as emprêsas passaram a representar nos tempos modernos provocaram uma reação contra o excessivo individualismo herdado do direito romano, surgindo princípio preservativo, que aos poucos vai dominando. A nova corrente determinou a revisão do princípio absolutista da dissolução e liquidação total da sociedade, passando a admitir, em certas hipóteses, a exclusão do sócio, para evitar a sua extinção.” (grifo no original) in R. REQUIÃO, A Preservação da Sociedade Comercial pela Exclusão do Sócio, p. 41

${ }^{30}$ O. INNOCENTI, L’Esclusione del Socio, p. 189-190.

31 "Gli interessi primi e veramente decisivi che vengono in considerazione sono di natura essenzialmente privata e patrimoniale.” in A. DALMARTELLO, L'Esclusione dei Soci dalle Società Commerciali, p. 41.
} 
livremente optar por excluir ou não o sócio inadimplente. Todavia, a razão de ser última do instituto reside no interesse coletivo de conservação da empresa produtiva, da qual a sociedade seja a titular. Em suma, em função da idéia de conservação da empresa, o interesse privado dos sócios adimplentes é imediatamente protegido, como um instrumento da tutela indireta e mediata do interesse público.

Não é por outra razão que o conceito de empresa é onipresente nas obras que tratam da exclusão de sócios e, quase sempre, funciona como pivô central das explicações oferecidas para a existência do instituto. Em sua clássica monografia, o Professor Arturo Dalmartello já enunciava a existência de um princípio preservativo da empresa por trás da disciplina da exclusão $^{32}$. Entre os doutrinadores nacionais, Hernani Estrella também se referiu ao mesmo princípio $^{33}$, enquanto o saudoso Professor Rubens Requião associou a exclusão de sócio à preservação da empresa já no título do célebre estudo que desenvolveu sobre o $\operatorname{argumento}^{34}$.

A seu turno, o Professor Fábio Konder Comparato, valendo-se da noção de contrato plurilateral, elevou expressamente a proteção da atividade empresarial ao posto de razão de ser do instituto da exclusão ${ }^{35}$, associando a consolidação deste último com a própria afirmação histórica do conceito de empresa.

O próprio artigo 1.085 do Código Civil de 2002, que disciplina a exclusão extrajudicial de sócios no âmbito das sociedades limitadas, atrela expressamente a aplicação de tal medida extrema a um risco evidente à “continuidade da empresa”.

Ainda que não exista dúvida quanto à função cardinal que a idéia de empresa desempenha em relação ao instituto da exclusão de sócios, é importante, contudo, recordar que tal conceito é multifacetado e que sua transposição da Economia para o Direito foi significativamente tormentosa. O principal escopo da teoria jurídica da empresa foi abrir a

\footnotetext{
${ }^{32}$ A. DALMARTELLO, L'Esclusione dei Soci dalle Società Commerciali, p. 29.

${ }^{33}$ H. ESTRELLA, Apuração dos Haveres de Sócio, p. 60.

${ }^{34}$ Obra denominada "A Preservação da Sociedade Comercial pela Exclusão de Sócio”, citada na bibliografia.

35 "O problema da exclusão de sócio só pode ser equacionado em função desse escopo comum, ou seja, se é indispensável para a realização do objetivo de produção e partilha de lucros, ou para a realização do objetivo de exploração de uma atividade empresarial o afastamento de um sócio, esse afastamento se justifica. Ele encontra uma razão de justiça e de direito, se pode ser admitido sem a extinção de todas as demais relações que entram num contrato de sociedade.” in F. COMPARATO, Exclusão de Sócio nas Sociedades por Quotas de Responsabilidade Limitada, p. 41.
} 
estrada para a unificação do Direito das Obrigações, ao substituir a pouco técnica teoria dos atos de comércio ${ }^{36}$, que de forma mais ou menos arbitrária e pouco rigorosa distinguia as diversas atividades econômicas em civis e comerciais. Esta última, a seu turno, foi desenvolvida, a partir do século XV, como uma forma de recepcionar e incorporar no ordenamento estatal as regras de Direito Comercial, até então de caráter estritamente corporativo, tornando-as objetivas, impessoais e de aplicação geral ${ }^{37}$.

Refazer esse longo percurso histórico extrapolaria as ambições e possibilidades deste estudo. Para a presente análise, convém simplesmente ressaltar que, dentre os quatro perfis da empresa identificados no clássico trabalho de Asquini, isto é: (i) o corporativo, (ii) o patrimonial, (iii) o subjetivo e (iv) o funcional. Apenas estes dois últimos possuem efetiva relevância direta para o tema da exclusão, com nítida preponderância entretanto para o perfil funcional, ou seja, a atividade ${ }^{38}$. De fato, na proteção da atividade econômica organizada profissionalmente (perfil funcional) reside o fundamento teleológico da exclusão de sócio ${ }^{39}$.

Desde sua gênese histórica, o instituto se presta também à proteção da sociedade, titular da empresa (perfil subjetivo), mas tal tutela é apenas instrumental à preservação da atividade. Se a atividade empresarial organizativa dos fatores de produção não possuísse um valor intrínseco, tanto para a coletividade como um todo quanto para os seus titulares, não haveria razão para proteger seu revestimento jurídico, a própria sociedade.

É importante recordar que, graças ao modo como a teoria da empresa foi incorporada no ordenamento brasileiro por meio do Código Civil de 2002, o instituto da exclusão facultativa se aplica também, por força do artigo 1.030, caput, às sociedades simples e às cooperativas (nos termos da remissão do artigo 1.096), as quais o legislador optou expressamente por classificar como não empresárias (artigo 982). Nestes termos, o uso da

\footnotetext{
${ }^{36}$ M. SALLES, A Visão Jurídica da Empresa na Realidade Brasileira Atual, p. 95 e 101. H. VERÇOSA, Curso de Direito Comercial, vol. 1, p. 108.

${ }^{37}$ F. GALGANO, Lex Mercatoria, p. 74.

${ }^{38}$ A. ASQUINI, I Profili dell'Impresa, p. 9-10. “...não é demais insistir no papel saliente que a a atividade econômica organizada tomou na conceituação e no enquadramento jurídico da empresa.” (grifo no original) in W. BULGARELLI, A Teoria Jurídica da Empresa - Análise da Empresarialidade, p. 142.

39 “È, in definitiva, sempre l'attività comune l'essenziale chiave di lettura della disciplina dell'esclusione, così come - in più ampia prospettiva - del suo contesto associativo di riferimento; ed è, appunto, a partire da questo dato interpretativo di fondo che è possibile delineare [...] alcune conclusioni relativamente al tema in discorso.” in M. PERRINO, Le Tecniche di Esclusione del Socio dalla Società, p. 130.
} 
expressão “atividade empresarial” para delimitar o sentido do instituto da exclusão facultativa não deixa de representar, no Brasil, um exercício de sinédoque redutiva (hiponímica), tomando-se a parte pelo todo ${ }^{40}$.

Com efeito, a exclusão de sócio busca tutelar não somente a atuação das sociedades empresárias, mas se aplica também a um campo mais amplo, que envolve a atividade econômica profissionalmente organizada das sociedades cooperativas e das sociedades que têm como escopo principal o desenvolvimento de atividades intelectuais, artísticas e científicas (Código Civil de 2002, artigo 966, parágrafo único).

Não fosse o uso já corrente e consolidado da expressão “atividade empresarial”, seria talvez mais correto usar o termo cunhado originalmente por Sylvio Marcondes, autor do capítulo do anteprojeto de lei que resultou no Código Civil de 2002, ou seja, “atividade negocial” ${ }^{41}$. Esta expressão inclui não somente as atividades de empresários individuais e sociedades empresárias, mas também os serviços de natureza artística, científica e intelectual que formam o campo de atuação das sociedades simples.

\subsubsection{Exclusão de Sócio e Propensão a Investir}

Não há dúvida de que a exclusão de sócio representa um valioso instrumento para a proteção da sociedade e, por conseguinte, da empresa, em seus momentos de turbulência. Por outro lado, se a exclusão é um mecanismo importante para a empresa já existente e em plena atividade, exatamente por tal razão também influencia as decisões de investidores potenciais, no que diz respeito ao uso da sociedade limitada como veículo para os seus empreendimentos futuros.

\footnotetext{
40 "Quanto ao termo Direito de Empresa, cabe assinalar que, graças a uma figura de metonímia, ou, por melhor dizer, de sinédoque, está aí a palavra empresa significando uma parte pelo todo que é o Direto de Sociedade. Fomos levados a essa opção por se cuidar mais, no citado Livro, da sociedade empresária, estabelecendo apenas os requisitos gerais da sociedade simples, objeto da diversificada legislação relativa aos múltiplos tipos das sociedades não empresariais.” (grifo no original) in M. REALE, A História do Novo Código Civil, p. 43

41 " $\mathrm{E}$, assim como, partindo do conceito de negócio jurídico, se erigem um sistema de atos, cabe assentar-se os postulados normativos do exercício da atividade. Atos negociais e, portanto, atividade negocial. Atividade que se manifesta economicamente na empresa e se exprime juridicamente na titularidade do empresário e no modo ou nas condições de seu exercício.” (grifo no original) in S. MARCONDES, Questões de Direito Comercial, p. 7.
} 
O contrato de sociedade é o típico exemplo de vínculo negocial de longa duração, com execução diferida e continuada, necessariamente sujeito a interações contínuas e complexas entre as partes contratantes. Em tal contexto, é absolutamente impossível para os sócios, no momento da formação da sociedade, prever todas as situações e eventos que terão um relevante impacto sobre as atividades sociais ou sobre a própria capacidade de cumprir com os compromissos assumidos perante os consócios. Com efeito, um dos principais elementos do risco da atividade empresarial deriva justamente do fato que, quando um sócio embarca em uma relação societária, desconhece uma série de elementos críticos ao sucesso da empreitada, a começar pela honestidade e sinceridade de seus consócios.

Tal fato acarreta inegável dose de incerteza, que separa a relação societária de transações sujeitas a execução imediata e instantânea, tal como, por exemplo, a compra e venda de um título em bolsa, com pagamento a vista, na qual o espaço para possíveis percalços é extremamente reduzido.

Nesse sentido, o contrato de sociedade se enquadra perfeitamente no conceito econômico de "contrato incompleto" 42 . A idéia de contrato incompleto parte da noção de custos de transação, que representam todos os custos, monetários ou não, incorridos com o fechamento de um negócio. Tais custos envolvem desde impostos a honorários advocatícios, compreendendo até mesmo o dispêndio de tempo e a impossibilidade de prospectar outras oportunidades durante o período em que o agente econômico se dedica às negociações de um determinado contrato.

Uma das grandes fontes de custos de transação é, precisamente, a incerteza e a correspondente necessidade de adquirir informações. Antes de encerrar um contrato, o interessado deve ao menos obter informações sobre a razoabilidade do preço oferecido e as condições gerais de mercado. Além disso, deve precaver-se contra a possibilidade de inadimplemento ou fraude de sua potencial contraparte, investigando a reputação desta última e, conforme o caso, exigindo a concessão de garantias. Contra riscos derivados de caso fortuito ou força maior, as partes podem se valer da contratação de um seguro. Tratando-se, por exemplo, da compra e venda de um bem imóvel, o comprador deve

${ }^{42}$ R. SZTAJN, H. VERÇOSA, A Incompletude do Contrato de Sociedade, p. 8. 
naturalmente investigar o estado físico e cadastral da coisa, bem como levantar a existência de reivindicações de terceiros.

Todas essas operações de minimização de incertezas, também denominadas contingências, implicam relevantes custos transacionais. Assim, mesmo que, por meio do recurso a tais medidas corretivas, fosse teoricamente possível afastar completamente as contingências de uma transação complexa e duradoura como a relação societária (o que na prática é impensável), o fato é que essa estratégia comportaria um enorme custo, seguramente superior ao lucro potencial que se poderia auferir com o próprio negócio.

A situação se agrava quando a natureza da transação exige investimentos especificamente moldados para o empreendimento em questão (relation-specific) e que, em caso de discórdia ou insucesso, exigiriam vultosas despesas para serem transferidos e utilizados em outros projetos. Trata-se do conceito econômico do "hold up problem"43 e, como exemplo, basta pensar na hipótese do sócio que integraliza sua quota em bens, conferindo ao capital de uma sociedade materiais de construção e equipamentos industriais pesados. Na hipótese de ruptura com os demais sócios, tal investidor enfrentaria, além da dificuldade (ou mesmo impossibilidade) técnica de mover e transportar tais bens, os custos decorrentes da batalha jurídica necessária para reavê-los ou obter o respectivo ressarcimento.

Como conseqüência de tais problemas, na presença de relevantes contingências, a tendência de um investidor racional seria simplesmente não concluir a transação em questão, com repercussões negativas para toda a economia, salvo se pudesse encontrar na legislação ou em arranjos contratuais específicos mecanismos adequados para ao menos mitigar tais incertezas. Tais mecanismos assumem, classicamente, a forma de (i) possibilidades de renegociação superveniente da avença e (ii) direitos de resilição unilateral $^{44}$.

\footnotetext{
43 "One party must make an investment to transact with another. This investment is relation-specific: that is, its value is appreciably lower (perhaps zero) in any use other than supporting the transaction between the two parties. Moreover, it is impossible to draw up a complete contract that covers all the possible issues that might arise in carrying out the transaction and could affect the sharing of the returns from the investment." in B. HOLMSTROM, J. ROBERTS, The Boundaries of the Firm Revisited, p. 74.

${ }_{44}$ "Sempre que os custos de adotar medidas extraordinárias superarem os benefícios esperados, uma das seguintes situações ocorre: (i) o contrato não é celebrado; (ii) deixa-se espaço para renegociação; ou (iii) possibilita-se a resilição unilateral.” in R. SZTAJN e H. VERÇOSA, A Incompletude do Contrato de Sociedade, p. 13
} 
Em tal âmbito, a exclusão facultativa de sócio representa justamente uma forma particular de resilição unilateral em favor da sociedade. Para um investidor, dada a impossibilidade de saber de antemão se seus sócios terão todas as qualidades e virtudes que apregoam possuir, a exclusão oferece uma importante forma de “saída de emergência”. Este instrumento evita que os sócios fiquem visceralmente atados a um consócio desonesto ou simplesmente sem condições de cumprir com as obrigações que assumiu perante a sociedade. Desse modo, a existência do mecanismo da exclusão representa um importante incentivo à própria decisão de investir na sociedade.

A aplicação do instituto deve, naturalmente, ser equilibrada e criteriosa, sempre rigorosamente condicionada à presença de uma justa causa (vide Capítulo 5), sob pena de se criar um efeito reverso: desestimular o investimento de possíveis sócios minoritários, temerosos de caírem vítima de um uso oportunista do instituto da exclusão por parte da maioria social.

\subsubsection{O Sentido da Exclusão Extrajudicial de Sócio}

O Código Civil de 2002 estabelece uma clara distinção entre dois regimes possíveis para a exclusão facultativa de sócio. Em primeiro lugar, o caput do artigo 1.030 - parte do capítulo que trata da sociedade simples e, portanto, aplicável a todos os tipos societários que tenham tal disciplina como regime subsidiário - prevê a possibilidade de exclusão judicial de um sócio por "falta grave" ou "incapacidade superveniente”. Por força de referência expressa presente no artigo 1.085, pode-se argumentar que tal artigo é aplicável a todas as sociedades limitadas, mesmo àquelas cujo contrato social determine a aplicação subsidiária das normas das sociedades anônimas ${ }^{45}$.

De outra parte, além de ressalvar o âmbito de aplicação do instituto da exclusão judicial, confirmando sua validade também para as sociedades limitadas, o próprio artigo 1.085, aplicável exclusivamente a este tipo societário, institui a possibilidade de exclusão extrajudicial de sócios.

\footnotetext{
${ }^{45}$ A interpretação e aplicação do parágrafo único do artigo 1.053 do Código Civil de 2002 é discutida de modo mais detido no Capítulo 4 do presente trabalho.
} 
O fato de que o artigo 1.030 imponha como condição para a viabilidade da exclusão judicial “a iniciativa da maioria dos demais sócios” não prejudica, de qualquer forma, a inequívoca distinção entre os dois procedimentos. No rito fixado pelo caput do artigo 1.030, a deliberação é apenas uma condição prévia para a proposição de medida judicial. Em tal caso, o status socii do excluendo permanece intocado até a emanação de uma decisão judicial favorável à exclusão (e, na maioria dos casos, até o trânsito em julgado desta última).

Por outro lado, a exclusão extrajudicial produz efeitos entre os sócios presentes à assembléia ou reunião já a partir da aprovação da respectiva deliberação e, perante terceiros e para fins de apuração de haveres (artigo 1.086), com o arquivamento da respectiva ata perante o competente registro das empresas mercantis. Nesta segunda hipótese, a deliberação dos sócios tem, em si, uma eficácia constitutiva negativa.

Tendo em vista as origens predominantemente doutrinárias e jurisprudenciais da exclusão de sócios no Brasil, calcada inicialmente no princípio majoritário e na liberdade de contratar, pode-se dizer que a exclusão extrajudicial se confunde com a própria história do instituto da expulsão de sócios.

Todavia, tal método tem sido por vezes contestado por parte de nossos doutrinadores. A principal razão para tal crítica residiria no fato de que, em termos práticos, a exclusão extrajudicial seria substancialmente inútil, uma vez que, na grande maioria dos casos, desembocaria em uma disputa judicial. Sob tal perspectiva, a expulsão extrajudicial não seria mais do que uma redundante etapa preliminar à subseqüente disputa travada perante os tribunais, um simples “estopim” em relação a esta última ${ }^{46}$.

O referido argumento, contudo, parece partir da falsa premissa de que o objetivo central da exclusão do procedimento extrajudicial seja evitar a deflagração de um conflito judicial ${ }^{47}$. Identificar em tal aspecto a razão de ser da exclusão extrajudicial seria, entretanto, atribuir extrema ingenuidade ao legislador nacional.

\footnotetext{
46 “...o que se verifica é que essa pretensa exclusão por deliberação majoritária de efeito imediato, na verdade, nada mais é do o estopim para o início de um processo judicial. Apenas se transfere o ônus da iniciativa para, justamente, o excluendo ou excluído. Não me parece que isso seja de inteira justiça.” in F. COMPARATO, Exclusão de Sócio nas Sociedades por Quotas de Responsabilidade Limitada, p. 39.

47 De qualquer forma, ainda que improvável, não é de se excluir de antemão a possibilidade de que o excluído acate a decisão da maioria social.
} 
Melhor razão parece assistir à posição defendida por Modesto Carvalhosa, que vislumbra na exclusão extrajudicial não uma antecipação e um prolongamento do conflito, mas um instrumento de inversão do ônus de recurso ao judiciário ${ }^{48}$. Enquanto espécie do gênero exclusão facultativa, a exclusão extrajudicial naturalmente tem como fundamento teleológico a proteção da atividade social (in casu, atividade empresarial porque o instituto é típico das sociedades limitadas). Porém, ao lado de tal objetivo geral, o instituto da exclusão extrajudicial se destina especificamente a resguardar a sociedade dos efeitos da lentidão processual.

A obtenção de uma decisão definitiva de mérito, mesmo que pela via arbitral, exige no mais das vezes um longo período, que pode variar de poucos meses a vários anos. Todo e qualquer processo de decisão de conflitos que se atenha minimamente aos princípios do contraditório e da ampla defesa será inevitavelmente lento. Contudo, no Brasil, a esta lentidão intrínseca somam-se os efeitos de um Judiciário com orçamento limitado e não plenamente informatizado, tribunais sobrecarregados por causas fiscais e previdenciárias (amiúde motivadas pela própria ação do Estado) e, enfim, por um sistema recursal exageradamente complexo ${ }^{49}$.

As lides relativas a conflitos societários tendem a ser particularmente longas e sujeitas a percalços, exigindo freqüentemente a realização de perícias contábeis, o seqüestro de livros e outros intrincados procedimentos probatórios. Ocorre que, justamente no âmbito das disputas societárias, a morosidade da solução de uma disputa se releva especialmente danosa. Na pendência da resolução de um conflito judicial, uma sociedade pode restar acéfala ou comportar-se como uma nau desgovernada, tendo sua administração e os rumos de sua gestão modificados ao sabor da última liminar obtida por cada um dos grupos de sócios em conflito. Em tais casos, além das perdas derivadas diretamente da falta de uma gestão coerente, a sociedade arca com as despesas de sua defesa judicial e sofre um dano de imagem em face de clientes, fornecedores e financiadores.

\footnotetext{
${ }^{48}$ M. CARVAlHOSA, Comentários ao Código Civil - Parte Especial do Direito de Empresa, p. 316.

${ }^{49}$ Um recente relatório do Banco Mundial, elaborado em parceria com a International Finance Corporation, coloca o Brasil na 106 a posição, em um universo de 177 países, no quesito “enforcement of agreements”. De acordo com tal estudo, para se fazer valer perante os tribunais brasileiros um contrato de baixa complexidade são necessários em média 661 dias. Vide WORLD BANK, Doing Business 2008 - Brazil, p. 44.
} 
No que tange especificamente a exclusão de sócios, é natural pensar que, após o protocolo do pedido de expulsão, o quotista que se pretende excluir esteja propenso a tomar medidas contrárias ao interesse social, em resposta à iniciativa de seus consócios. Em tal caso, a morosidade na resolução definitiva do conflito prolonga uma situação extremamente desgastante e amplia exponencialmente as oportunidades para que o excluendo faça um uso abusivo do seu status de sócio.

De fato, com um pedido de exclusão já em curso e sendo provável um desfecho negativo, o excluendo teria pouco ou nada a perder com a adoção de estratégias como o obstrucionismo em deliberações sociais (abuso do direito de voto); a solicitação exagerada e repetitiva de informações sobre a sociedade (abuso do direito de informação) ou divulgação no mercado de informações falsas e difamatórias sobre a empresa (violação do dever de lealdade).

Tais ações podem ter simples escopo de retaliação ou serem usadas como instrumento de pressão para coagir a sociedade e os consócios a aceitarem uma transação favorável às pretensões do excluendo. Medidas cautelares podem ser pouco eficazes contra estratégias de tal gênero e, em regra, os tribunais serão pouco propensos a conceder a tutela antecipada em uma lide que envolva matéria tão delicada e complexa quanto a exclusão de sócio. Quanto maior for o intervalo entre a formalização do pedido de exclusão por parte da sociedade e a efetivação da expulsão, maiores serão os riscos para o interesse social e para a atividade empresária.

O grande mérito da exclusão extrajudicial é exatamente permitir que a apreciação dos fundamentos e da licitude da expulsão por parte da autoridade judiciária transcorra sem a presença do excluído no quadro de sócios. Por esta via, a exclusão tem eficácia imediatamente após a deliberação dos consócios. Em uma inversão do que normalmente ocorre, caberá ao excluído, caso entenda que a exclusão foi injusta ou que qualquer de seus direitos foram violados com o procedimento, o ônus e a iniciativa de submeter a questão à autoridade judiciária.

O juízo competente para apreciar tal demanda poderá, naturalmente, reverter a decisão da sociedade e ainda determinar o ressarcimento dos prejuízos sofridos pelo sócio indevidamente excluído. Todavia, o aspecto mais importante (e aí se identifica o 
fundamento teleológico da exclusão extrajudicial de sócios) é que, durante a avaliação da questão pelo Judiciário, a sociedade e a empresa da qual esta última seja titular ficam em uma posição menos vulnerável. 


\section{FUNDAMENTO DOGMÁTICO}

Ao avaliar as diferentes correntes e opiniões dos autores que até então haviam se dedicado à questão da exclusão de sócios, Arturo Dalmartello, autor da já mencionada clássica monografia sobre este tema, percebeu que as posições então em voga poderiam ser divididas em três grupos principais, de acordo com o fundamento dogmático eleito como base para a aplicação do remédio da expulsão ${ }^{1}$.

Com efeito, em seu memorável estudo, Dalmartello concluiu que as explicações existentes em seu período para a natureza jurídica da exclusão de sócios poderiam ser decantadas em três teses essenciais: (i) a da disciplina legal e taxativa, (ii) a da manifestação do poder institucional-disciplinar da sociedade e (iii) a da resolução contratual por inadimplemento.

\subsection{Disciplina Legal Taxativa}

Como mencionado no Capítulo 1, o Código Comercial Italiano de 1882 não previa nenhuma hipótese ampla e aberta de exclusão por inadimplemento grave, mas antes determinava que o instituto fosse aplicável a um determinado número de casos, específica e expressamente estabelecidos pela própria lei. Com o passar do tempo, contudo, passou a consolidar-se a visão de que tal rol de hipóteses era meramente exemplificativo e não numerus clausus ${ }^{2}$.

Contrários a tal visão ampliativa da lei, os partidários da tese da disciplina legal-taxativa viam na exclusão uma sanção imposta diretamente pelo legislador, em nome do interesse público. Enquanto instrumento punitivo e de caráter excepcional, a exclusão poderia apenas ser disciplinada pelo legislador e pronunciada pelo juiz ${ }^{3}$. Essa visão lhes permitia contrastar as interpretações extensivas do Código Comercial Italiano, reafirmando a idéia

\footnotetext{
${ }^{1}$ A. DALMARTELLO, L'Esclusione dei Soci dalle Società Commerciali, p. 19.

${ }^{2}$ G. BOLLINO, Le Cause di Esclusione del Socio nelle Società di Persone e nelle Cooperative, parte I, p. 381.

3 “L'esclusione sarebbe [para a doutrina da disciplina legal taxativa] [...] un rimedio imposto dalla necessità di utilità generale e avrebbe il suo fondamento nella sola legge, che non sarebbe altro se non l'autoritaria e categorica espressione di superiori esigenza economiche.” in A. DALMARTELLO, L'Esclusione dei Soci dalle Società Commerciali, p. 41.
} 
de que não seria possível qualquer outra possibilidade de exclusão que não aquelas explicitamente consagradas pela legislação comercial ${ }^{4}$.

Dalmartello recorre a dois argumentos principais, estreitamente interligados um ao outro, para refutar a doutrina da disciplina legal taxativa. O primeiro é o da prevalência imediata do interesse privado na exclusão de sócios, enquanto o segundo diz respeito à inadequação da classificação da exclusão como uma penalidade.

O célebre autor recorda, de fato, que as origens históricas do instituto da exclusão derivam do próprio desenvolvimento da dissolução das sociedades, sempre dentro dos limites do Direito Privado e com nítidas características contratuais ${ }^{5}$. As principais hipóteses de exclusão são facultativas, ou seja, estão condicionadas não somente à verificação de determinadas hipóteses (não integralização das quotas, incapacidade superveniente do sócio, etc.), mas também a uma decisão dos demais sócios favorável à aplicação do instituto, em cada situação concreta. Como discutido de forma mais detida no capítulo precedente, tal fato demonstra inequivocamente que o fundamento teleológico imediato por trás dos casos de exclusão facultativa é a tutela dos interesses dos sócios e da sociedade, e não a proteção do interesse público. Tal como já se teve a oportunidade de argumentar, o interesse público é tutelado de forma apenas mediata pelo instituto da exclusão de sócio.

Por outro lado, a exclusão não pode ser considerada uma pena imposta pela lei porque se aplica a determinadas situações em que, possivelmente, não se verifica qualquer traço de dolo ou culpa por parte do sócio excluendo ${ }^{6}$. De fato, a noção de pena, contrariamente a uma simples reação ao inadimplemento, está estruturalmente ligada às idéias de dolo ou culpa. O foco de qualquer penalidade é precisamente dissuadir o agente de praticar uma ação ou incorrer em omissão. Desse modo, é descabido aplicar uma penalidade a hipóteses que fogem completamente ao controle ou à vontade do sócio, tal como a própria hipótese de exclusão por incapacidade superveniente (Código Civil de 2002, artigo 1.030, caput).

\footnotetext{
4 “Corollario di questa teoria è inevitabilmente la affermazione del carattere eccezionale della esclusione e conseguentemente la affermazione della tassatività delle cause di esclusione.” in B. ACQUAS, C. LECIS, L'Esclusione del Socio nelle Società di Persone, p. 32

${ }^{5}$ A. DALMARTELLO, L'Esclusione dei Soci dalle Società Commerciali, p. 43.

${ }^{6}$ A. NUNES, O Direito de Exclusão de Sócios nas Sociedades Comerciais, p. 45.
} 
Ademais, caso se tratasse de uma pena, a exclusão teria de necessariamente ser aplicada a todas as hipóteses substancialmente similares. Por uma questão de isonomia e eqüidade, o remédio da expulsão (caso tivesse a natureza de pena) não poderia ser aplicado em determinados casos para, em um momento seguinte, deixar ser utilizado em relação a uma hipótese substancialmente similar, em função de mera conveniência da sociedade ou em razão da vontade dos sócios remanescentes. Uma vez mais, é o caráter automático, cogente e necessário da aplicação do remédio da expulsão, ínsito à doutrina da disciplina legal taxativa, que impede que esta seja tomada como fundamento geral da exclusão de sócios.

Além dos argumentos colacionados por Dalmartello, é importante salientar, outrossim, que se a exclusão de sócios fosse uma manifestação de um comando legal destinado à tutela do interesse público, o reconhecimento da presença dos respectivos pressupostos e a efetiva aplicação do instituto seriam, naturalmente, competência exclusiva da autoridade judicial. Em tal caso, seria absolutamente inviável que a exclusão do sócio fosse declarada extrajudicialmente pela assembléia ou reunião dos sócios, tal como é expressamente admitido tanto pelas normas italianas quanto pela disciplina brasileira.

A este propósito, convém recordar que, mesmo sujeita a posterior controle judicial, a deliberação de exclusão extrajudicial possui uma eficácia constitutiva negativa própria. Caso não exista oposição judicial, a simples deliberação dos consócios priva, por si só, o excluendo da qualidade de sócio. Se, ao contrário, a matéria for submetida à apreciação da autoridade judicial, a eventual decisão de mérito do juiz não poderá fazer mais do que confirmar a validade de tal deliberação ou meramente reconhecer sua invalidade. Ou seja, uma sentença sobre a questão teria apenas eficácia declaratória e não constitutiva negativa.

Desse modo, a aceitação da doutrina da disciplina legal taxativa estaria em contradição com os termos expressos da legislação atinente à exclusão de sócios (artigo 1.085 do Código Civil de 2002), que inequivocamente contempla a possibilidade de exclusão extrajudicial. Pretendida como fundamento geral do instituto da exclusão (ou ao menos da exclusão facultativa, como se discute adiante), a tese da disciplina legal taxativa, para ser válida, não poderia ser aplicável somente à exclusão processada judicialmente.

Por fim, ocorre mencionar que, mesmo sob um ponto de vista prático e pragmático, ou ainda sob uma perspectiva de lege ferenda, a prevalência da teoria da disciplina legal 
taxativa seria inconveniente. De fato, tratando-se de um imperativo normativo de caráter público e punitivo, as normas relativas à exclusão deveriam necessariamente ser interpretadas de modo restritivo. Em tal contexto, os pressupostos de aplicação da exclusão deveriam ser específica e expressamente previstos pela legislação, não sendo compatíveis com fórmulas abertas e flexíveis, que permitissem a expulsão do sócio em casos de "falta grave” ou “atos de inegável gravidade”. Em tal hipótese, a exclusão de sócios seria um instrumento demasiadamente rígido, incapaz de abarcar a complexidade da vida empresarial e de fazer frente às inúmeras situações que podem tornar necessário ou útil o afastamento de um sócio ${ }^{7}$.

\subsection{Poder Corporativo Disciplinar}

Rechaçada a tese da disciplina legal taxativa, Dalmartello passa a atacar a doutrina do poder corporativo disciplinar, segundo a qual o instituto da exclusão seria uma expressão da ascendência hierárquica que existiria em favor de qualquer ente coletivo (consórcio, associação ou sociedade), em relação aos seus associados. De acordo com essa visão, seria inerente à constituição de qualquer ente coletivo uma delegação a este último das prerrogativas necessárias à organização das suas atividades e defesa da própria existência. Entre tais prerrogativas, estaria o poder de impor penalidades aos próprios membros e, em casos extremos, destituí-los da qualidade de sócio ou associado.

A principal deficiência da doutrina em questão reside justamente na premissa de que existe uma relação de submissão hierárquica do sócio frente à sociedade. Como brilhantemente sintetiza Dalmartello, a sociedade é um instrumento de execução unitária e coordenada do contrato social $^{8}$. Coordenação não significa, todavia, comando ou tampouco sujeição. Entre sociedade e sócio existe uma intricada rede de direitos e obrigações, pesos e contrapesos, mas não uma relação de submissão.

O reconhecimento de uma precedência hierárquica da sociedade sobre o sócio acarretaria duas conseqüências extremamente negativas. Em primeiro lugar, poderia se argumentar que, enquanto expressão do exercício de uma prerrogativa "soberana” ou emanação de potestas, o mérito da deliberação de exclusão não poderia ser reapreciado pela autoridade

\footnotetext{
${ }^{7}$ J. LUCENA, Das Sociedades Limitadas, p. 702-703.

${ }^{8}$ A. DALMARTELLO, L'Esclusione dei Soci dalle Società Commerciali, p. 63.
} 
judiciária ${ }^{9}$. Tratar-se-ia de um ato discricionário da sociedade e ao Judiciário caberia, portanto, no máximo, verificar o respeito aos pressupostos formais do procedimento de exclusão $^{10}$.

A segunda questão, diretamente relacionada com a primeira, é que a pretensa soberania da sociedade sobre o sócio seria, de fato, exercida pela maioria social, graças à sua capacidade de determinar os rumos da administração. O resultado final não seria outro que não a absoluta arbitrariedade dos sócios majoritários em prejuízo dos minoritários. Citando Vivante, Dalmartello recorda o velho brocardo latino segundo o qual "par in parem non habet imperium"11.

Cumpre recordar, outrossim, que a doutrina do poder corporativo disciplinar é particularmente deficiente no que se refere à aplicação da exclusão de sócios no âmbito das sociedades desprovidas de personalidade jurídica ${ }^{12}$. Trata-se de uma questão de menor importância no ordenamento brasileiro, no qual se reconhece a personalidade jurídica a quase todas as sociedades (salvo a sociedade em comum e a sociedade em conta de participação), mas extremamente relevante em jurisdições como a Itália e a Alemanha, nas quais se atribui apenas personalidade jurídica “imperfeita” às sociedades de pessoas (que representam o principal campo de incidência do remédio da exclusão).

Despida de uma personalidade jurídica própria, a sociedade não poderia ser investida, nem ser titular, de qualquer poder sobre os sócios. Nesses casos, a aplicação do remédio da exclusão pode ser explicada apenas pela teoria da disciplina legal taxativa ou da resolução contratual por inadimplemento.

\footnotetext{
${ }^{9}$ Segundo Dalmartello, faltaria à decisão de exclusão a “...insindacabilità che è la più salente e necessaria conseguenza della manifestazione di un potere sovrano.” in A. DALMARTELLO, L'Esclusione dei Soci dalle Società Commerciali, p. 65.

${ }^{10}$ Também contrário à possibilidade de se impedir o controle judicial sobre o mérito da decisão de exclusão, Pontes de Miranda afirmou que "Discute-se se pode o juiz descer ao exame da causa para a exclusão e apreciar o ato da assembléia, ou de outro órgão, eliminativo do membro (validade material). A resposta é afirmativa: pode o juiz descer à verificação da justiça na apreciação do fato, que motivou a exclusão.” in F. MIRANDA, Tratado de Direito Privado, Parte Geral, Tomo I, p. 405.

11 "I soci costituenti la maggioranza potrebbero spezzare, col solo pretesto di esprimersi la signorile volontà dell'ente, tutti i vincoli giuridici [...] che li legano ai consoci della minoranza e quindi ignorare completamente di aver stipulato con essi un contratto e di esservi tenuti.” in A. DALMARTELLO, L'Esclusione dei Soci dalle Società Commerciali, p. 64.

${ }^{12}$ A. DALMARTELLO, L'Esclusione dei Soci dalle Società Commerciali, p. 68.
} 
É importante considerar, outrossim, que uma “medida disciplinar” não deixa de ter um caráter de pena, compartilhando parte das dificuldades decorrentes da aceitação da doutrina da disciplina legal taxativa, discutidas anteriormente. Com efeito, uma penalidade, ainda que aplicada interna corporis, deve seguir os critérios de eqüidade e justiça e ter como único objetivo inibir a repetição da conduta indesejada. Não poderia, portanto, estar sujeita à conveniência da sociedade e não se explicaria sua aplicação a hipóteses absolutamente fora do controle do sócio excluendo, tal qual a incapacidade superveniente.

A esse respeito, Waldecy Lucena oportunamente recorda que é muito comum a prática de se estabelecer sanções, penalidades e procedimentos internos disciplinares nos estatutos sociais das associações ${ }^{13}$. Freqüentemente, tais sanções alcançam a própria perda do status de associado. Efetivamente, o artigo 54, inciso II, do Código Civil de 2002 determina que os procedimentos para a exclusão do associado consistem em um dos requisitos essenciais do estatuto social das associações. Entretanto, (i) o fato de que a doutrina do poder corporativo disciplinar fosse eventualmente considerada válida em relação às associações não significaria que esta seria automaticamente aplicável também às sociedades, e (ii) mesmo no âmbito das associações, existem sérios obstáculos à aceitação da teoria em questão.

Convém primeiramente salientar que a estrutura jurídica e econômica das associações é extremamente diversa daquela das sociedades, a despeito de ambas estarem agrupadas sobre o conceito de contrato plurilateral. As associações, por definição, perseguem fins não econômicos e não distribuem resultados entre seus associados, de modo que resta muito reduzido o espaço para conflitos de interesse entre seus membros se comparado ao que normalmente se verifica nas sociedades. Este fato permite uma "distância institucional” muito maior na relações dos associados entre si e entre estes últimos e a própria associação do que aquela existente no universo das sociedades. Não é por acaso que o parágrafo único do artigo 53, do Código Civil de 2002, sublinha expressamente o fato de que a associação não cria direitos e obrigações recíprocos entre os associados.

Ademais, é importante ter em consideração que as associações representam tendencialmente espaços mais “democráticos” do que as sociedades. Nos termos do artigo

${ }^{13}$ J. LUCENA, Das Sociedades Limitadas, p. 703-704 (nota de rodapé). 
55 do Código Civil de 2002, as prerrogativas de cada um dos associados são, em princípio, equivalentes, ainda que estes possam ser divididos em diferentes categorias com privilégios especiais. A adoção da doutrina do poder corporativo disciplinar resultaria, portanto, em menor risco de abuso e arbitrariedade. Nas sociedades, em contraste, (especialmente na sociedade limitada) os direitos e obrigações de cada um dos sócios são proporcionais à participação detida no capital social, existindo maior espaço para abusos por parte da maioria social.

De qualquer forma, mesmo entre as associações, a prevalência da doutrina do poder corporativo disciplinar deixaria sem resposta o problema do controle judicial sobre o mérito da deliberação de exclusão. Parte da jurisprudência buscou equivocadamente aproximar a deliberação de exclusão das associações às decisões de órgãos públicos, de forma a encampar a primeira sob a teoria do ato administrativo e argumentar que ao Judiciário não caberia mais do que efetuar um controle dos aspectos formais do ato de expulsão do associado ${ }^{14}$.

Ocorre, contudo, que tanto o regime das associações disciplinadas pelo Código Civil, quanto evidentemente suas deliberações, incluindo a decisão de exclusão, possuem caráter nitidamente privado e não podem ser acomunados a institutos de Direito Público. Quando um órgão associativo se exprime, é a própria associação que se manifesta. Enquanto parte da disputa que cerca a exclusão, a associação não pode julgar, nem em âmbito judicial ou arbitral, nem tampouco de forma “administrativa” ${ }^{15}$. Tal linha de raciocínio analógica teria algum sentido, quando muito, se aplicada às associações privadas que exercem uma atividade de natureza pública, tal qual o fornecimento de serviços de educação.

\subsection{Resolução do Contrato por Inadimplemento}

A terceira possibilidade trazida à tona por Dalmartello como explicação geral para o instituto em exame, eleita pelo autor como a mais adequada, sugere que a exclusão de sócios seria uma simples expressão particular do princípio geral da resolução do contrato

\footnotetext{
14 “Controle jurisdicional possível apenas quanto à formalidade do ato, que foi observada.” TJSP, Apelação Cível n³ 324.654.4/1-00, Relator Exmo. Des. Sergio Gomes, 27/03/2007.

15 “Quanto à submissão compulsória das questões entre associados, ou sócios, e a pessoa jurídica, regem os princípios gerais, - não podendo, é claro, ser árbitro em causa sua o que é parte; nem órgão da pessoa jurídica, porque seria ela.” in F. MIRANDA, Tratado de Direito Privado, Parte Geral, Tomo I, p. 404.
} 
por inadimplemento ${ }^{16}$. De acordo com tal proposição, a exclusão seria um instrumento de caráter privado, claramente assentado no seio do Direito das Obrigações, que permitiria à sociedade responder ao inadimplemento grave de um dos sócios por meio da resolução do vínculo contratual mantido como o quotista inadimplente.

A principal vantagem da doutrina da resolução do contrato por inadimplemento, em comparação à tese da disciplina legal taxativa, é conferir ao instituto maior flexibilidade, assegurando aos sócios a prerrogativa de optar por não aplicar o remédio da exclusão, mesmo quando estejam presentes os respectivos pressupostos legais, sempre que o melhor interesse da sociedade assim aconselhar. Com efeito, uma vez que se identifique o escopo principal da exclusão na defesa da empresa (conforme o Capítulo 2), não há razão para que a norma não estabeleça em favor ultimada sociedade (ainda que por meio de deliberação de seus sócios), a oportunidade de avaliar a conveniência da exclusão em cada situação concreta.

Como já indicado anteriormente, a descapitalização da sociedade decorrente da necessidade de apurar e pagar os haveres do excluendo pode, em inúmeros casos, decretar a própria inviabilidade do empreendimento. É, portanto, plausível que em determinados casos os sócios prefiram tolerar um inadimplemento de um consócio, mesmo que grave, ou então recorrem a outros instrumentos jurídicos para a proteção dos interesses sociedade.

Por outro lado, a identificação de um fundamento contratual para a exclusão demonstra-se superior à doutrina do poder corporativo disciplinar enquanto prescinde de qualquer relação hierárquica entre sociedade e sócio e demonstra-se compatível com um pleno controle externo da decisão de exclusão por parte do Judiciário.

Naturalmente, a estrutura do contrato de sociedade não comporta a pura e simples aplicação do princípio da resolução contratual por inadimplemento, tal como prevista, por exemplo, pelo artigo 475 do Código Civil de 2002 e que, tipicamente, comporta o término do próprio contrato como um todo. Aplicada ao contrato de sociedade, como por gerações

\footnotetext{
${ }^{16}$ Ocorre assinalar que, já sob uma perspectiva contratual, Dalmartello se indaga se a exclusão poderia ser uma manifestação condição resolutiva, mas recusa tal teoria porque (i) em tal caso, a própria condição e suas conseqüências deveriam ser estipuladas pelas partes e não supletivamente pela lei e (ii) a verificação da condição deveria, em rigor, dar lugar ao recesso do sócio em favor do qual foi imposta e não à expulsão do excluendo. A. DALMARTELLO, L'Esclusione dei Soci dalle Società Commerciali, p. 75.
} 
propugnou a posição romanista-individualista (vide Capítulo 1), tal solução extrema seria, na maioria dos casos, mais danosa do que a própria conduta do excluendo e absolutamente contraproducente em termos de preservação da empresa.

Ocorre que, ao contrário do que se verifica nos contratos bilaterais, não existe no contrato de sociedade uma necessária equivalência recíproca entre as prestações de cada sócio ${ }^{17}$. O sinalagma está presente no contrato de sociedade, mas não entre os sócios reciprocamente. A relação sinalagmática forma-se, de fato, entre cada um dos sócios e a própria sociedade. No contrato de sociedade, as prestações de cada sócio não se contrapõem mutuamente nem necessariamente se equivalem, como tipicamente se verifica nos contratos de escambo, mas se alinham em direção a um ponto focal único: o fim comum.

É por esta razão que o contrato de sociedade é considerado o exemplo perfeito, ainda que não único ${ }^{18}$, de “contrato plurilateral”, também conhecido como "associativo” ou de “escopo comum”. Não se trata de uma questão de número de partes, pois é perfeitamente possível, e mesmo corriqueiro, que um contrato bilateral possua mais do que duas partes ou que uma sociedade tenha somente dois sócios. O aspecto principal é justamente a estrutura dos direitos e obrigações das partes em cada um dos arranjos contratuais em exame: (i) contrapostas e reciprocamente equivalentes nos contratos bilaterais; (ii) sem equivalência recíproca e alinhadas em favor de um objetivo comum, nos contratos plurilaterais.

A formulação do conceito de contrato plurilateral tem sua origem na antiga constatação de que a maioria dos princípios gerais do Direito dos Contratos eram perfeitamente válidos em relação à sociedade comercial, enquanto alguns preceitos específicos - até então julgados gerais e transversais a todas as formas contratuais - não poderiam ser aplicados em âmbito societário, salvo se com grandes adaptações e ressalvas ${ }^{19}$.

Nesse sentido, ilustrativamente, o reconhecimento da nulidade de um vínculo contratual implica, entre os contratos “normais” bilaterais, o imediato retorno das partes ao status quo

\footnotetext{
${ }^{17}$ M. CARVAlHOSA, Comentários ao Código Civil - Parte Especial do Direito de Empresa, p. 309.

${ }^{18}$ P. FERRO-LUZZI, I Contratti Associativi, p. 23-24.

19 "Na realidade, pode-se dizer tradicional a sensação da diferença entre o contrato de sociedade e os contratos que poderíamos dizer, genéricamente, de permuta, e, realmente, a doutrina sempre examinou alguns problemas (por ex., o da exceptio inadimpleti contractus) em relação aos quais algumas regras gerais dos contratos pareciam de difícil aplicação ao contrato de sociedade.” in T. ASCARELLI, O Contrato Plurilateral, p. 255. P. FERRO-LUZZI, I Contratti Associativi, p. 5-6.
} 
ante, exatamente porque o contrato nulo não deve, em tese, produzir efeitos. Em âmbito societário, tal solução seria extremamente danosa, sobretudo para terceiros de boa-fé que houvessem realizado negócios com a sociedade antes que fosse constada a nulidade de seus atos constitutivos ${ }^{20}$, razão pela qual se impõe, em tal hipótese, a dissolução da sociedade e a abertura do seu processo de liquidação (artigo 1.034, inciso I, do Código Civil de 2002).

Um outro exemplo da especialidade do contrato de sociedade é a não incidência da exceção do contrato não cumprido (exceptio inadimpleti contractus, artigo 476 do Código Civil de 2002) a diversos aspectos das relações inter-sócios. De fato, não pode um sócio recusar a integralização de sua quota simplesmente porque um outro consócio inadimpliu tal obrigação. Efetivamente, se tal prerrogativa fosse aplicável à hipótese em exame, os principais prejudicados seriam justamente os demais sócios adimplentes e a própria sociedade, com evidentes reflexos negativos para os credores desta última. Cumpre recordar que a prestação é devida à sociedade e não aos demais sócios.

Tais características particulares impulsionaram a doutrina a uma profunda revisão do Direito dos Contratos ${ }^{21}$. Assim, ao invés de simplesmente se recusar o status de contrato ao negócio de sociedade, acabou por prevalecer a idéia de que os contratos se dividem em dois principais grupos: (i) bilaterais (cujo exemplo clássico é o contrato de compra e venda) e (ii) plurilaterais (além do contrato de sociedade, são exemplos a associação e o consórcio de sociedades). Como resultado, certos princípios antes tidos como gerais e aplicáveis a todos os contratos são, atualmente, considerados preceitos típicos apenas dos contratos bilaterais.

Com o tempo, a teoria da sociedade como contrato plurilateral demonstrou ser mais rigorosa e apta a explicar a natureza das relações societárias e, assim, acabou por sobrepujar explicações não-contratuais do negócio de sociedade, notadamente a tese da sociedade como instituição e a doutrina do ato complexo (Gesamtakt) ${ }^{22}$.

\footnotetext{
${ }^{20}$ P. FERRO-LUZZI, I Contratti Associativi, p. 17.

${ }^{21}$ P. FERRO-LUZZI, I Contratti Associativi, p. 32.

${ }^{22}$ P. FERRO-LUZZI, I Contratti Associativi, p. 44.
} 
Os doutrinadores brasileiros puderam testemunhar tal processo de uma perspectiva privilegiada, graças à passagem pelo Brasil, na metade do século XX, de Tullio Ascarelli, um dos principais expoentes e grande consolidador da teoria do contrato plurilateral ${ }^{23}$.

Nesse sentido, o fato de que a resolução do contrato por inadimplemento não se aplique ao contrato de sociedade da mesma forma que incide sobre os contratos bilaterais (isto é, determinando o próprio fim do contrato) não pode servir como argumento para se refutar o fundamento contratual do instituto da exclusão de sócios. Tal característica representa, ao contrário, uma reafirmação e um reflexo da especialidade do Direito Societário, estando plenamente em linha com a doutrina dos contratos plurilaterais.

Além do término apenas parcial da avença, a segunda grande adaptação exigida pela aplicação do princípio da resolução do contrato por inadimplemento ao contrato (plurilateral) de sociedade diz respeito à titularidade do direito de exigir a resolução parcial, que é atribuída à própria sociedade e não individualmente a cada um dos sócios adimplentes. De fato, como indicado no Capítulo 5, o inadimplemento capaz de ensejar a exclusão de um sócio deve necessariamente referir-se a uma obrigação de natureza societária, existente no plano sócio-sociedade, e não às relações bilaterais existentes entre os sócios.

Ademais, a exclusão é um instrumento de preservação e tutela da sociedade, enquanto titular de uma atividade empresarial. Portanto, é natural que caiba exclusivamente ao próprio ente societário, ainda que mediante prévia deliberação dos sócios adimplentes, o direito de aplicar ou não o remédio da expulsão.

Além disso, sendo apenas a própria sociedade titular de tal prerrogativa é possível assegurar que a exclusão seja aplicada de forma coordenada e organizada. Se cada um dos sócios ou grupos de sócios pudesse reivindicar a exclusão de um consócio considerado inadimplente, existiria o risco de se formar um verdadeiro labirinto de demandas recíprocas de exclusão. É por esta razão que se atribui ao sócio, agindo de forma unilateral e isolada, somente o poder de resolver o seu próprio vínculo contratual com a sociedade,

\footnotetext{
${ }^{23}$ T. ASCARELLI, O Contrato Plurilateral, p. 256.
} 
através das modalidades de retirada e recesso, nos casos especificamente disciplinados pela lei, e não a prerrogativa de, por iniciativa individual, afastar seus consócios.

\subsection{Inadequação da Unicidade de Fundamento Dogmático}

É notável como, a despeito de ter nascido em um contexto histórico e normativo específico, a classificação dos possíveis fundamentos para a exclusão de sócio sugerida por Dalmartello, bem como sua defesa da superioridade da teoria contratual, tenham sido citadas e repetidas em diversas das monografias posteriores que trataram deste tema, seja na Itália, seja no Brasil, bem como em outras jurisdições ${ }^{24}$.

Tal fato é testemunho tanto da solidez da argumentação proposta pelo douto autor italiano, quanto da capacidade da doutrina da resolução do contrato por inadimplemento de explicar a maior parte das facetas do instituto da exclusão de sócios ${ }^{25}$. Por outro lado, a persistente referência, sem maiores ressalvas ou objeções, à posição defendida por Dalmartello demonstra uma certa postura acrítica dos doutrinadores que o sucederam, sobretudo em relação às hipóteses de exclusão de sócio ipso iure, que não parecem compatíveis com o fundamento dogmático contratual.

O jurista italiano chegou a reconhecer as dificuldades de se enquadrar alguns casos típicos de exclusão do sócio - notadamente a falência, a incapacidade superveniente e a inabilitação do sócio - sob o conceito comum de inadimplemento ${ }^{26}$. Entretanto, no momento em que Dalmartello desenvolveu seus estudos e publicou sua renomada monografia, o Código Civil de 1942 não havia sido promulgado e o ordenamento italiano não previa nenhuma hipótese de exclusão de sócio de pleno direito. Em tal contexto, havia espaço para se argumentar, como fez o autor, que todas as referidas hipóteses, inclusive a falência, representariam relevantes modificações da situação pessoal do sócio, criando situações incompatíveis com o cumprimento do dever de colaboração com a sociedade ${ }^{27}$.

\footnotetext{
${ }^{24}$ Apenas como exemplos: A. NUNES, O Direito de Exclusão de Sócios nas Sociedades Comerciais, p. 37. B. CAILLAUD, L'Exclusion d'un Associé dans les Sociétés, p. 238. R. VILLAVERDE, La Exclusion de Socios - Causas Legales, p. 30. R. REQUIÃO, A Preservação da Sociedade Comercial pela Exclusão do Sócio, p. 15. S. LATORRACA, Exclusão de Sócio nas Sociedades por Quotas, p. 3. J. LUCENA, Das Sociedades Limitadas, p. 702.

${ }^{25}$ Uma das poucas vozes dissidentes é Osmida Innocenti, favorável à adoção da disciplina legal taxativa como fundamento geral do instituto da exclusão de sócio. O. INNOCENTI, L'Esclusione del Socio, p. 190.

${ }^{26}$ A. DALMARTELLO, L'Esclusione dei Soci dalle Società Commerciali, p. 71.

27 A. DALMARTELLO, L'Esclusione dei Soci dalle Società Commerciali, p. 89.
} 
Contudo, o artigo 2.288 do Código Civil Italiano de 1942 inaugurou naquele ordenamento as hipóteses de exclusão de pleno direito do sócio falido e daquele que tivesse sua quota liquidada para a satisfação de dívida particular ${ }^{28}$, tornando inviável transpor para o novo regime o esforço obstinado de Dalmartello de aglutinar todas as possíveis causas de exclusão sob o fundamento comum da resolução do contrato por inadimplemento. Da mesma forma que, como discutido no capítulo anterior, a expulsão ipso iure não parece se orientar pelos mesmos fundamentos teleológicos da exclusão facultativa, é possível argumentar que a primeira, contrariamente à segunda, não se coaduna com o fundamento contratual que Dalmartello vislumbrou como base única do instituto de exclusão.

De fato, os mesmos argumentos levantados por Dalmartello para refutar a doutrina da disciplina legal taxativa como explicação geral para a exclusão de sócios podem ser empregados para demonstrar a inadequação do enquadramento da exclusão de pleno direito sob o manto da resolução contratual por inadimplemento.

O aspecto crucial de tal discussão reside no automatismo com a qual a exclusão ipso iure, até mesmo por definição, deve ser aplicada, sempre que verificados os respectivos pressupostos estabelecidos pela lei, sem qualquer consideração ao interesse da sociedade ou à vontade dos sócios remanescentes. Esta característica, como já debatido no capítulo antecedente, indica que a exclusão de pleno direito se inspira predominantemente na defesa do interesse público, em contraste com a natureza prevalentemente privatística das hipóteses de exclusão facultativa.

Além disso, cumpre recordar que, na hipótese de falência do sócio - principal caso de exclusão de pleno direito prevista pela lei italiana e, mais recentemente, também pela brasileira $^{29}$ - não existe necessariamente um claro e direto inadimplemento do sócio frente à sociedade. Poderia se argumentar que a falência do sócio representa, em si, um dano de imagem à sociedade e, portanto, uma violação do dever de colaboração. Tal proposição, entretanto, soa pouco convincente nos casos em que o sócio falido seja minoritário e não

\footnotetext{
${ }^{28}$ O caráter de "novidade" de tais disposições é confirmado por Giuseppe Bollino: "La novità introdotta dal codice civile del 1942 in materia di esclusione del socio dalle società personali consiste, pertanto, essenzialmente nella previsione del fallimento e della liquidazione della quota da parte del creditore particolare del socio come cause di esclusione automatica..." in G. BOLLINO, Le Cause di Esclusione del Socio nelle Società di Persone e nelle Cooperative, parte I, p. 381-382.

${ }^{29}$ Como discutido no Capítulo 2, pode-se argumentar que a "exclusão" do sócio em função de liquidação de sua quota para satisfação de débito particular não representa uma verdadeira hipótese de exclusão e, de qualquer forma, não se aplica atualmente às sociedades limitadas.
} 
participe da administração da sociedade e, de qualquer modo, caso se tratasse de um instituto de natureza privada, caberia naturalmente à contraparte lesada (a sociedade) decidir sobre a oportunidade da resolução do vínculo contratual.

Nesse sentido, a exclusão de pleno direito reveste-se de todos os traços característicos de um comando legal cogente e não de uma prerrogativa contratual, que pode ser exercida ou não pela sociedade de acordo com seus interesses.

No Brasil, o panorama normativo anterior à promulgação do Código Civil de 2002, que não contemplava a exclusão de pleno direito e sequer disciplinava adequadamente a questão da exclusão facultativa, criava um ambiente propício à plena aceitação da existência de um fundamento único e de natureza contratual, para o instituto da exclusão de sócios. Entretanto, como já mencionado, o Código Civil de 2002, na esteira da legislação italiana, introduziu em nosso ordenamento o conceito de exclusão de pleno direito, por meio do parágrafo único do artigo 1.030, exigindo, portanto, que a questão também seja afrontada sob o Direito brasileiro.

Existem, fundamentalmente, duas alternativas possíveis para lidar com tal questão: (i) rejeitar a tese de Dalmartello de que todas as hipóteses de exclusão podem ser abrigadas sob um único fundamento, reconhecendo que as hipóteses de exclusão facultativa, baseadas no princípio da resolução contratual por inadimplemento, convivem com a exclusão de pleno direito, expressão de uma disciplina legal taxativa, ou (ii) argumentar que a exclusão de sócio strictu sensu abrange somente a exclusão facultativa e que a exclusão de pleno direito, a despeito de seu nomem juris, representaria um instituto distinto.

Nesta última hipótese, poderia se recorrer, conforme a sugestão de alguns estudiosos ${ }^{30}$, à distinção entre (i) “expulsão”, que indicaria somente a extromissão do sócio por questões externas à sociedade e (ii) “exclusão”, relativa ao afastamento de um quotista do quadro de sócios em função de procedimento (judicial ou não) com origem interna à própria sociedade.

\footnotetext{
${ }^{30}$ F. COMPARATO, Exclusão de Sócio nas Sociedades por Cotas de Responsabilidade Limitada, p. 46-47. R. RIBEIRO, Exclusão nas Sociedades Anônimas, p. 101.
} 
De qualquer modo, trata-se de uma discussão em grande medida meramente terminológica, cujo aprofundamento foge aos objetivos deste trabalho. O principal desdobramento de tal questão para a presente análise é simplesmente confirmar que as hipóteses de exclusão de pleno direito, de um lado, e as de exclusão facultativa, do outro, operam sob lógicas marcadamente diversas e se baseiam em fundamentos dogmáticos distintos, a despeito do nomen juris comum. 


\section{A SOCIEDADE LIMITADA NO CÓDIGO CIVIL DE 2002}

\subsection{Nota Crítica ao Código Civil de 2002 em Matéria de Sociedades}

Dentre todas as modificações introduzidas no ordenamento brasileiro pelo Código Civil de 2002, o Livro II (“Do Direito de Empresa”) representa uma das mais profundas inovações em relação ao regime anterior, mas, ao mesmo tempo, é quase certamente a passagem que recebeu as mais severas críticas por parte da doutrina. De fato, a despeito de suas notáveis ambições (unificar o Direito das Obrigações por meio da adoção da Teoria da Empresa e suprir o laconismo do Decreto de 3.708/19), e não obstante o inequívoco brilhantismo e incontestável erudição jurídica de seus principais formuladores, não se pode dizer que o “Livro da Empresa” do Código Civil de 2002 seja um sucesso ou que tenha atendido às necessidades dos empreendedores brasileiros no momento de sua promulgação.

Em apertada síntese, pode-se apontar três principais deficiências da nova legislação: (i) transposição direta de institutos de Direito Comparado, sem atentar adequadamente às idiossincrasias da tradição jurídica brasileira, (ii) o caráter obsoleto de suas disposições e (iii) o excessivo intervencionismo, fortemente limitador da liberdade contratual.

O Livro da Empresa brasileiro inspira-se inequivocamente no Código Civil Italiano de $1942^{1}$. Em relação a algumas matérias, tal como a disciplina da exclusão de pleno direito (artigo 2.288 do Código Civil Italiano e parágrafo único do artigo 1.030 de nosso próprio código) a transposição de noções e conceitos é de tal forma direta que parece haver uma efetiva transcrição de determinados trechos.

Ocorre que a legislação societária italiana do período tomado como referência não representava um modelo de extremo sucesso, capaz de justificar essa absorção pouco crítica de suas disposições. Em diversos aspectos, as normas brasileiras eram mais avançadas e amadurecidas do que as suas correspondentes peninsulares. Em relação à própria sociedade por quotas de responsabilidade limitada, por exemplo, o Brasil foi sabidamente, na esteira de Portugal, o quinto país do mundo a instituir tal tipo societário, já

\footnotetext{
1 “A primeira e mais marcante impressão que a leitura do Projeto desperta é a de que a inspiração direta da reforma legal brasileira, no âmbito empresarial, provém do Código Civil Italiano de 1942.” in W. BULGARELLI, A Teoria Jurídica da Empresa - Uma Análise Jurídica da Empresarialidade, p. 7.
} 
no ano de $1919^{2}$. A Itália por outro lado, apenas incorporou tal forma de sociedade em seu ordenamento em 1942, quando o projeto Asquini de Código Civil foi convertido em lei. Trata-se de um diploma que inevitavelmente reflete as idéias corporativistas inerentes ao contexto histórico em que foi concebido, frequentemente criticado pela doutrina italiana como inferior ao projeto de Vivante, discutido duas décadas antes ${ }^{3}$.

Nesse sentido, é efetivamente criticável que o Código Civil de 2002 tenha ignorado o fato de que, já então, a prática empresarial brasileira relegava paulatinamente as sociedades com responsabilidade ilimitada ao desuso, e tenha incorporado institutos e conceitos absolutamente estranhos à nossa tradição jurídica, tal como a própria sociedade simples, atribuindo a esta última, outrossim, um papel central na nova disciplina ${ }^{4}$.

Como peculiar ironia histórica, ocorre ressaltar que, poucos dias após o fim da vacatio legis do Código Civil de 2002, a Itália aprovou (com o Decreto 6/2003, de 17 de janeiro de 2003) uma ampla reforma atualizadora de seu Direito Societário. E, em tal ponto, a questão da inspiração estrangeira da nova legislação se entrelaça com o segundo principal problema do Livro da Empresa: o caráter obsoleto das novas normas, que desde o momento de sua promulgação já se mostravam em descompasso com a realidade econômica do país.

É verdade que as normas não possuem, em si, data de validade. Ao contrário, as leis que são capazes de incorporar e refletir com precisão princípios e valores perenes de uma coletividade tendem a perdurar e, com o tempo, adquirem o mérito adicional de terem suas eventuais dúvidas de interpretação decantadas pela jurisprudência. Basta pensar no exemplo da GmbhG alemã, pioneira legislação em matéria de estabelecimento da sociedade com responsabilidade limitada no âmbito dos ordenamentos que aderem à tradição do Civil Law. Mesmo que com diversas alterações, a lei de 1892 ainda disciplina este tipo societário na Alemanha.

Por outro lado, é igualmente verdadeiro que profundas mudanças sócio-econômicas podem tornar uma norma obsoleta e incapaz de atender aos reclamos concretos de uma

\footnotetext{
2 J. LUCENA, Das Sociedades Limitadas, p. 12.

${ }^{3}$ F. MAGLIULO e F. TASSINARI, Evoluzione Storica e Tipo Normativo, p. 4-5

${ }^{4}$ V. FRANCO, O Triste Fim das Sociedades Limitadas no Novo Código Civil, p. 82.
} 
coletividade. A capacidade de uma lei de se adaptar e responder às mutantes necessidades de uma população é inversamente proporcional à minuciosidade com que busca disciplinar uma matéria. O laconismo do Decreto $\mathrm{n}^{0}$ 3.708/19 e sua longa e ininterrupta vigência, a despeito das profundas transformações da economia brasileira nesse período, são testemunhos de tal fato ${ }^{5}$.

Nesse contexto, (i) o trâmite legislativo anormalmente longo do projeto que resultou na promulgação da Lei Federal $n^{\circ}$ 10.406/02, (ii) sua inspiração direta no Código Civil Italiano de 1942, bem como (iii) as ambições da nova norma de oferecer tratamento exaustivo e detalhado a diversas questões tiveram como resultado inevitável o fato de que o Livro da Empresa fosse desatualizado desde o seu nascimento.

Efetivamente, é importante recordar que as origens do Livro II do Código Civil de 2002 são anteriores à própria formulação do anteprojeto de lei (iniciada a partir de 1972) que, após tramitação notavelmente prolongada, resultaria na atual Lei Federal no 10.406/02. De fato, o capítulo em questão nasceu inicialmente como parte do projeto de Código das Obrigações Brasileiro, de 1964, uma das mais notáveis tentativas preliminares de unificação do Direito Civil e Comercial no país, já sob a autoria do saudoso e ilustre Professor Sylvio Marcondes ${ }^{6}$.

Sucessivamente, o trabalho do Professor Marcondes foi incorporado e absorvido ao anteprojeto que se tornaria o Projeto de Lei do Executivo $n^{\circ}$ 634/75. Na versão apresentada inicialmente ao Congresso, esta passagem do projeto de lei denominava-se "Da Atividade Negocial” e não “Livro da Empresa”. A denominação sugerida inicialmente pelo Professor Marcondes seria mais rigorosa e técnica, dado que o capítulo em questão disciplina também sociedades que exercem atividade profissional de natureza científica, artística ou intelectual e que, portanto, nos termos do atual artigo 966, parágrafo único, do Código Civil de 2002, combinado com o artigos 967 e 982, não podem ser consideradas empresárias. O saudoso Professor Miguel Reale, contudo, entendeu (como indicado

\footnotetext{
5 “Nem hoje se pode dizer, passados oitenta e quatro (1919-2003), que foi o período de sua vigência, tenha o Decreto $\mathrm{n}^{\circ} 3.708$ sido um 'tormento para o comércio'. [...] Parcas sendo suas disposições, tal acabou por resultar em benefício da larga expansão desse tipo societário, porquanto abriu ensanchas à fértil imaginação dos interessados, que assim puderam livremente moldar, segundos suas necessidades e conveniências, as sociedades que idealizavam.” in J. LUCENA, Das Sociedades Limitadas, p. 29.

${ }^{6}$ S. MARCONDES, Questões de Direito Comercial, p. 3.
} 
anteriormente) que era cabível aplicar o nome de uma parte ao todo, uma vez que o capítulo em questão tratava principalmente da atividade empresarial ${ }^{7}$.

O aspecto crucial, contudo, é que a “data mental” da nova lei não é 2002, mas sim a metade do século passado ${ }^{8}$. A despeito da vigorosa defesa da atualidade do Código promovida pelo próprio Professor Miguel Reale ${ }^{9}$, não é possível concordar com o argumento de que as emendas introduzidas durante a maturação legislativa do Projeto de Lei do Executivo $n^{\circ}$ 634/75 possam ter alterado estruturalmente uma norma inspirada diretamente em idéias e preceitos com mais de meio século de existência, sobretudo porque se trata de um período de profundas mudanças na sociedade e na economia brasileiras.

É importante recordar, outrossim, que mesmo no início da década de 70 importantes juristas brasileiros já haviam manifestado suas relevantes dúvidas e reservas em relação ao anteprojeto que resultaria na nova lei ${ }^{10}$. Ademais, não se pode desconsiderar o fato de que, passados quase 30 anos do início das discussões legislativas, prevalecia certa descrença quanto à efetiva promulgação do novo Código, de forma que grande parte da atenção da doutrina se depositou sobre outras propostas de $l \mathrm{ei}^{11}$.

A própria ambição exaustiva presente no Código Civil de 2002, fiel ao modelo dos Códigos Civis Suíço e Italiano, representa uma técnica legislativa atualmente em desuso. Tendo em vista a importância do tipo societário em exame, além de seu peculiar caráter híbrido, teria sido mais adequado oferecer à sociedade limitada um tratamento análogo ao

\footnotetext{
${ }^{7}$ M. REALE, A História do Novo Código Civil, p. 43.

8 "Concebido no início da segunda metade do século passado, com anteprojeto apresentado em 1972 [...], sua data mental é bem essa. Os revisores do Código não atentaram [...] para os profundos avanços ocorridos em direito societário nas últimas décadas do século passado, e de que é candente exemplo, para se ater somente a um caso, a sociedade unipessoal de responsabilidade limitada...” (grifo no original) J. LUCENA, Das Sociedades Limitadas, p. 32.

9 "Não tem cabimento, por conseguinte, a prevenida afirmação de que o novo Código Civil já teria nascido velho, por se vincular a um Projeto enviado ao Congresso Nacional em 1975. Raciocina-se, em tal caso, como se não houvesse sido aprovada cada fase de tramitação histórica para a oportuna adequação do Projeto às vicissitudes históricas.” in M. REALE, A História do Novo Código Civil, p. 25-26.

${ }^{10}$ A respeito desta passagem do Projeto de Código Civil, Oscar Barreto Filho já observava em 1972, no que hoje soa quase profético, que: "Parece-nos que, sem embargo do elevado critério científico e sistemático que orientou os trabalhos de elaboração do projeto de Código Civil, a inclusão da matéria referente aos empresários e às sociedades em um código de direito privado não seria conveniente nem oportuna, pois ensejaria a cristalização de soluções que não se coadunam com a hora de transformação das instituições econômicas por que atravessa o Brasil, em ritmo até mais acelerado do que em outros países.” in. O. BARRETO FILHO, O Projeto de Código Civil e as Normas sobre a Atividade Negocial, p. 101.

${ }^{11}$ Tal como, por exemplo, o projeto de código das sociedades do Professor Jorge Lobo. V. FRANCO, $O$ Triste Fim das Sociedades Limitadas no Novo Código Civil, p. 84.
} 
concedido à sociedade anônima, disciplinando-a por meio de lei especial. Ou então, como alternativa, a revogação das disposições societárias do Código Comercial de 1850 poderia ter sido colhida como oportunidade para a elaboração de um Código das Sociedades, oferecendo tratamento unificado a todos os tipos societários, seguindo os recentes exemplos de Espanha e Portugal ${ }^{12}$. Na atual configuração da legislação brasileira, a peculiar inserção de normas gerais de Direito Societário (fusão, transformação etc.) na lei das sociedades anônimas, uma lei especial, foi transformada em uma desastrada duplicidade de tais dispositivos, a partir da promulgação do Código Civil de 2002.

De qualquer forma, a principal deficiência do Código Civil de 2002 em matéria societária está na sua forte limitação da liberdade contratual dos sócios, particularmente no âmbito da sociedade limitada, em evidente contraste com a anterior tradição brasileira. O laconismo do Decreto 3.708/19 implicava certa dose de insegurança jurídica, mas também assegurava enorme espaço para a autonomia das partes.

Os dois elementos mais relevantes de limitação da liberdade contratual presentes na nova legislação são: (i) a reversão da hierarquia das fontes normativas subsidiárias à sociedade limitada, desprivilegiando a posição e o valor das disposições do contrato social (como discutido mais detalhadamente no tópico a seguir) e (ii) a introdução de uma série de regras cogentes, incidentes sobre o funcionamento interno da sociedade, sobretudo em relação aos quoruns de deliberação.

Esta característica do Código Civil de 2002 revela, de um lado, um afã intervencionista de oferecer um tratamento exaustivo, orientado pela idéia de preencher supostas lacunas e deficiências do antigo regime das sociedades por quotas de responsabilidade limitada. Com efeito, o Professor Sylvio Marcondes não escondeu sua grande insatisfação com o (parco) conteúdo Decreto n 3.708/19, cuja exigüidade vislumbrou como resultado de uma alegada desídia do legislador de $1919^{13}$.

\footnotetext{
${ }^{12}$ V. FRANCO, O Triste Fim das Sociedades Limitadas no Novo Código Civil, p. 83.

13 "O legislador brasileiro, vamos dizer honestamente, por comodismo, ao invés de estruturar a sociedade limitada como um tipo próprio, misto, fez a sua hibridez resultar da seguinte formulação: a sociedade deve ser constituída na forma das demais sociedades do Código Comercial - arts. 300, 301, 302 - onde se configuram as sociedades de pessoas; acresce mais alguns dispositivos e, a seguir, o famigerado art. 18, dispondo que, para os casos omissos no contrato social, utilizar-se-á a lei das sociedades anônimas, no que for aplicável. Está é solução das mais infelizes, em matéria de elaboração legislativa, porque "no que for aplicável' é, às vezes, tão subjetivo, que torna inviável [sic] a certeza e a segurança do negócio pretendido." (sem grifo no original) in S. MARCONDES, Questões de Direito Comercial, p. 18-19.
} 
Por outro lado, e possivelmente com conseqüências mais graves, verifica-se que as disposições societárias do Código Civil de 2002 se pautam inequivocamente em uma presunção de hipossuficiência da minoria social. Efetivamente, o Professor Miguel Reale não hesitou em denunciar a disciplina de ampla liberdade contratual estabelecida pelo Decreto 3.708/19 como um regime de “odiosos privilégios” em favor dos sócios controladores ${ }^{14}$. Infelizmente, a principal via adotada pelos formuladores do anteprojeto do Código Civil de 2002 para reverter a suposta situação de injustiça foi o estabelecimento, por meio de normas cogentes, de quoruns qualificados de deliberação (principalmente por meio do artigo 1.076, inciso I), com grande dano para a liberdade de organização da sociedade pelos próprios sócios.

A este respeito, é importante recordar que a relação entre sócios majoritários e minoritários não pode ser comparada ou equiparada, por exemplo, àquelas existentes entre fornecedor e consumidor ou empregador e empregado. O minoritário não é necessariamente parte fraca, frágil ou oprimida da relação societária. Basta pensar na hipótese em que um grande fundo de investimento adquira uma participação minoritária em uma sociedade limitada, controlada por um grupo familiar. É plausível, se não mesmo provável, que os gestores do fundo de investimento tenham um conhecimento mais profundo do mercado em questão do que a própria administração da sociedade, bem como utilizem os instrumentos previstos na legislação societária com mais desenvoltura e eficácia.

Não é razoável, portanto, tomar como base para a legislação societária um juízo geral e pré-concebido (em parte, até mesmo maniqueísta) sobre a correlação de forças em cada arranjo societário, sobretudo porque a sociedade limitada é utilizada no Brasil em uma ampla variedade de situações, dos mais simples aos mais complexos empreendimentos.

O sócio de uma sociedade empresária, seja minoritário ou majoritário, é alguém que, por definição, aceita e tolera o risco da atividade empresarial, em função da perspectiva de obter lucro. Na sociedade, a participação no capital social determina a medida em que cada

\footnotetext{
${ }^{14}$ M. REALE, Direito de Empresa: Fim de Odiosos Privilégios, p. 1. "Entre os diplomas legais que não asseguram os direitos e interesses dos sócios minoritários figura o antigo Dec. 3.708, de 10 de janeiro de 1919, que ainda disciplina as sociedades por quotas de responsabilidade limitada, permitindo abusivas decisões por parte dos que detêm a maioria de seu capital social, sem que a minoria tenha condições de participar eqüitativamente dos lucros sociais, fazendo valer os seus direitos.” in M. REALE, A História do Novo Código Civil, p. 203.
} 
sócio (i) contribui para a formação do patrimônio da sociedade e (ii) se expõe ao risco de insucesso do empreendimento. Conseqüentemente, é natural e lógico que o valor da participação seja de algum modo proporcional ao poder atribuído ao sócio de influenciar as decisões da sociedade (ressalvada a sociedade cooperativa, na qual prevalece o mutualismo).

Naturalmente, o poder de controle não significa direito ao domínio absoluto da sociedade. É cioso recordar que a tutela do abuso de controle é um dos temas perenes e mais importantes do Direito Societário. Todavia, parece muito mais adequado que a posição do sócio minoritário seja resguardada através do acesso à informação, do direito de recesso e da vedação da atuação em conflito de interesse - em linha com a anterior tradição brasileira e consoante o Direito Comparado - do que por meio de um engessamento dos quoruns de deliberação dos órgãos sociais, tal como fez o legislador de 2002.

Além disso, os critérios de deliberação representam uma questão predominantemente interna à própria sociedade, sem impacto direto sobre os interesses de seus credores e terceiros. O sócio é o melhor avaliador de seu próprio interesse, da relevância da contribuição de cada um dos consócios e - por conseguinte - do quinhão de poder nas deliberações sociais que exige para si ou está disposto a ceder aos demais. Não se justifica, destarte, a grande limitação da liberdade contratual imposta pelo Código Civil de 2002 às sociedades limitadas, em prejuízo da autonomia das partes e eficiência decisória do ente social.

A sujeição de qualquer mudança do contrato social ao voto afirmativo de sócios detentores de três quartos do capital social (artigo 1.076, inciso I), somada ao fato de que quase todos os aspectos relevantes da sociedade devem ser disciplinados por tal documento, implica que a sociedade limitada pode facilmente se tornar vítima de estratégias obstrucionistas da minoria social. Essa característica cria campo fértil para o abuso do direito de voto e, fatalmente, tende a ser um dos principais motivos que exigirão a aplicação do remédio da exclusão no futuro.

De qualquer modo, cumpre também reconhecer os pontos positivos do Livro da Empresa. Em termos gerais, o aspecto mais interessante foi a própria adoção da Teoria da Empresa, que dá nome ao capítulo, em substituição à teoria dos atos de comércio. Ainda que de 
forma confusa e, uma vez mais, abusando das remissões normativas, a nova lei substitui a antiga, mas arbitrária e pouco técnica, divisão dos atos em civis e comerciais e adotou como ponto cardinal para erigir uma nova distinção o exercício de uma atividade econômica, de forma organizada e habitual ${ }^{15}$.

A adoção da Teoria da Empresa abriu, desse modo, a estrada para a unificação do Direito das Obrigações, permitindo a superação da confusa e inadequada duplicidade de formas contratuais (por exemplo, a compra e venda civil e compra e venda mercantil) que prevalecia no período de vigência paralela do Código Civil de 1916 e do Código Comercial de 1850 (este último ainda aplicável a algumas questões de Direito Marítimo).

Nos poucos casos em que se julgou necessário manter uma divisão de esferas no âmbito do Direto Privado - em questões como, por exemplo, o registro competente para o arquivamento dos atos constitutivos, a admissão da falência e a penhorabilidade da participação societária -, a noção de empresarialidade realiza função análoga àquela anteriormente desenvolvida pela divisão dos atos entre civis e comerciais.

Em termos específicos, ocorre registrar o fato de que o Código Civil de 2002 reconheceu expressa e inequivocamente a existência do direito à exclusão do sócio (além da hipótese de exclusão do remisso), prescindindo das reviravoltas hermenêuticas e esforços de interpretação que foram necessários para arrancar a idêntica conclusão do Código Comercial de 1850. De fato, até a promulgação do Novo Código, a possibilidade de exclusão por justa causa havia sido apenas indiretamente acolhida por normas que disciplinavam o registro mercantil (conforme discutido no Capítulo 1).

\subsection{Normas Aplicáveis à Sociedade Limitada}

Ao discutir os princípios que orientaram a elaboração do anteprojeto que resultou no Código Civil de 2002, o saudoso Professor Miguel Reale atribuiu destaque à questão da “operabilidade”, ou seja, à busca intencional e pragmática por soluções simples, que facilitassem a interpretação e a aplicação da lei ${ }^{16}$. Como exemplo do emprego da aplicação

\footnotetext{
${ }^{15}$ S. MARCONDES, Questões de Direito Comercial, p. 10-11.

16 "Em um estojo especial guardo o texto do Anteprojeto sitematizado com todas as sugestões que julguei oportuno fazer aos membros da Comissão. Foram elas do mais variado espectro, mas com a nota dominante de firmar no Código as diretrizes de eticidade, socialidade e operabilidade...” (grifo no original) in $\mathrm{M}$. REALE, História do Novo Código Civil, p. 20.
} 
prática de tal premissa metodológica, o próprio Mestre citava a explícita diferenciação estabelecida pelo novo diploma entre os conceitos de decadência e prescrição, em uma tentativa de superar querela nunca adequadamente solucionada pela doutrina ou pelos tribunais na vigência do Código de 1916. Outra possível ilustração do princípio foi a clara distinção entre as noções de "sociedade" e "associação" 17 .

Nessa mesma esteira, o Professor Miguel Reale também se revelou atento à necessidade do uso parcimonioso de remissões entre diferentes artigos do mesmo texto normativo, reconhecendo e destacando as relevantes dificuldades de interpretação que podem resultar do apelo exagerado a tal técnica ${ }^{18}$.

Não obstante e com a devida vênia, pode-se argumentar que nenhum dos dois mencionados preceitos foi adequadamente respeitado na formulação do anteprojeto que resultou no Título II do Livro da Empresa, no Código Civil de 2002.

O novo diploma inicialmente repete método empregado pelo Código Civil Italiano, ao tomar a sociedade simples ${ }^{19}$ como regime de base para as demais sociedades não sujeitas expressamente a regras especiais. Desse modo, ao tratar dos outros tipos societários, o legislador aborda exclusivamente o que há de específico em cada um deles (sobretudo o regime de responsabilidade de cada classe de sócios), uma vez que as disposições de caráter mais genérico (administração, fiscalização etc.) já foram estipuladas no capítulo dedicado às sociedades simples.

Entre as principais diferenças entre o Código Civil de 2002 e a lei italiana, cabe destacar que esta última realiza as remissões de modo escalonado. Como regime suplementar às regras da sociedade em comandita simples se aplicam, por exemplo, as regras da sociedade em nome coletivo (artigo 2.315, Código Civil Italiano de 1942), cujas lacunas, a seu turno, são supridas pelas normas da sociedade simples (artigo 2.293). Ou seja, o regime

\footnotetext{
${ }^{17}$ M. REALE, História do Novo Código Civil, p. 40.

18 "O problema das remissões é mais denso de conseqüências do que à primeira vista parece, inclusive quando se tem por fim determinar o sentido pleno dos dispositivos, correlacionando-os logicamente com os de conotação complementar. Se o significado de um dispositivo legal depende da totalidade do ordenamento, essa exigência hermenêutica cresce de ponto, particularizando-se, quando o próprio legislador se refere a outros preceitos para a integração normativa. É a razão pela qual o legislador deve vincular, com a devida parcimônia, um artigo a outros, deixando essa tarefa à dinâmica criadora da doutrina, à luz dos fatos e valores emergentes.” in M. REALE, História do Novo Código Civil, p. 83-84.

${ }^{19}$ Artigos 2.293, 2.315, 2.519 e 2.454 do Código Civil Italiano de 1942.
} 
suplementar da sociedade em comandita simples é formado pela soma das disposições da sociedade em nome coletivo e da sociedade em comandita simples. A lei brasileira, ao contrário, retorna sempre diretamente ao regime de base da sociedade simples (ressalvada as sociedades por ações), sem complementá-lo com as disposições atinentes às demais sociedades empresárias ${ }^{20}$.

A escolha do legislador brasileiro de tomar uma sociedade expressamente não-empresária como referencial normativo para os demais tipos societários é, por si só, criticável ${ }^{21}$. Não obstante, cumpre reconhecer que essa estrutura de sucessivas remissões evita repetições desnecessárias e demonstra-se razoavelmente adequada à disciplina das sociedades em nome coletivo e em comandita simples (respectivamente, artigos 1.040 e 1.046 do Código Civil de 2002). As particularidades de tais tipos societários puderam, de fato, ser tratadas e delimitadas em alguns poucos artigos, que bastam para estabelecer as necessárias adaptações em relação ao regime básico e geral da sociedade simples.

Contudo, a técnica legislativa em questão foi definitivamente menos feliz em relação à sociedade limitada. O capítulo que trata desse tipo societário é relativamente amplo, contando com trinta e quatro extensos artigos, e contém inúmeros pontos de sobreposição e possível conflito com a disciplina das sociedades simples. Assim, as normas da sociedade limitada não se restringem a simplesmente lapidar o regime básico das sociedades simples, de forma adaptá-lo na medida necessário, tal como se verifica com as sociedades em nome coletivo e em comandita simples. As normas próprias da sociedade limitada formam em seu conjunto uma disciplina paralela, quase autônoma, mas ainda assim incompleta, que se sobrepõe problematicamente às regras de referência do tipo societário não-empresário.

\footnotetext{
${ }^{20}$ Além disso, as sociedades cooperativas italianas sujeitam-se à regência supletiva das sociedade por ações (equivalente à nossa anônima) e não ao regime das sociedades simples, como prevê a lei brasileira (artigo 1.096). Especificamente no que tange a società a responsabilità limitata, não consta do Código Civil italiano uma expressa remissão ao regime das sociedades por ações, a despeito do fato de a sociedade limitada italiana ter sido pensada e construída como uma mera versão simplificada desta última. A esse respeito: “Nel testo definitivo degli artt. 242 ss. c.c., in conclusione, la s.r.l. si presenta decisamente, più che come un nuovo tipo intermedio tra s.p.a. e società di persone, come una piccola società per azioni la cui unica peculiarità significativa, rispetto al modello di riferimento, è data dal divieto di emissione di azioni (e di obbligazioni), e dalla autonoma disciplina della quota di partecipazione che tal divieto necessariamente comporta.” in F. MAGLIULO e F. TASSINARI, Evoluzione Storica e Tipo Normativo, p. 6.

${ }^{21}$ M. CARVAlHOSA, Comentários ao Código Civil - Parte Especial do Direito de Empresa, p. 40. V. FRANCO, O Triste Fim das Sociedades Limitadas no Novo Código Civil, p. 82.
} 
Ademais, na sociedade limitada, a remissão ampla e geral ao regime das sociedades simples, contida no caput do artigo 1.053, convive com uma série de referências diretas e pontuais às regras deste último tipo societário, tais como, por exemplo, aquelas constantes dos artigos 1.070 (referência ao artigo 1.010), artigo 1.077 (remissão ao artigo 1.031) e artigo 1.085 (que se remete ao artigo 1.030). A ausência de claros critérios de interpretação e coordenação entre tais normas torna particularmente árdua a tarefa de identificar efetivas lacunas no regime das sociedades limitadas para, em seguida, verificar a necessidade e a possibilidade de se recorrer à disciplina supletiva das sociedades simples.

A questão, que em si já não é modo algum simples, adquire exponencialmente maior complexidade quando se toma em consideração o disposto no parágrafo único do artigo 1.053 do Código Civil de 2002. Esse dispositivo, que confere aos quotistas a faculdade de adotar, por meio de cláusula expressa no contrato social, as normas da sociedade anônima como regime supletivo, teve origem em uma intervenção direta e pessoal do Professor Miguel Reale no texto do anteprojeto de Código $\mathrm{Civil}^{22}$. Com efeito, na redação originalmente formulada pelo Professor Sylvio Marcondes, o anteprojeto previa simplesmente a aplicação supletiva das normas da sociedade simples, sem a possibilidade de se recorrer, em caráter subsidiário, ao regime das sociedades por ações.

A modificação introduzida pelo Professor Miguel Reale teve o mérito inequívoco de criar uma brecha para a aplicação das normas das sociedades anônimas às sociedades limitadas. A idéia chave por trás da introdução do parágrafo único do artigo 1.053 foi fazer aplicar, no silêncio (intencional ou não) do contrato social, o regime das sociedades simples às pequenas e médias empresas, reservando às grandes empresas que adotassem a forma de sociedade limitada a possibilidade de se valer do regime das sociedades anônimas.

Na prática, contudo, tendo em vista a rigidez e o caráter obsoleto das normas das sociedades simples, é de se imaginar que mesmo os pequenos empreendedores tenderão a adotar a regência supletiva das normas relativas às sociedades anônimas. Trata-se, de fato, de uma disciplina ironicamente mais moderna e dinâmica do que aquela instituída pelo

\footnotetext{
22 "Cabe salientar que, de início, inexistia o citado parágrafo único do art. 1.053, de maneira que todas as omissões eram regidas pela 'sociedade simples', o que me pareceu inadequado, propondo ao saudoso senador Josaphat Marinho, relator geral da matéria no Senado Federal, a faculdade de ser estabelecida no contrato social a preferência pelas regras relativas às sociedades anônimas.” in M. REALE, A História do Novo Código Civil, p. 215.
} 
Código Civil de 2002 - esta última, frise-se, inspirada diretamente em normas italianas da metade do século $X X$ - que possui a vantagem adicional de já ter sido longamente submetida à análise de nossos tribunais, diminuindo o espaço para dúvidas de interpretação. Além disso, a regra contida no parágrafo único do artigo 1.053 não deixa de representar um importante sopro de liberdade contratual, em um texto caracterizado por um pesado intervencionismo do legislador.

Por outro lado, é impossível não reconhecer que a utilização de tal prerrogativa em um caso concreto implica um grave aprofundamento das dificuldades existentes na identificação das normas aplicáveis à sociedade limitada. O principal problema reside no fato de que a lei não é absolutamente clara ao indicar se a regência supletiva das normas típicas das sociedades anônimas, quando estabelecida expressamente no contrato social, deve ocorrer em complementação ou em substituição às regras da sociedade simples.

De acordo com a primeira opção, as normas das sociedades anônimas se sobreporiam e se somariam àquelas próprias das sociedades limitadas e àquelas supletivas das sociedades simples, representando uma terceira camada normativa. Assim, as regras das sociedades anônimas seriam apenas utilizadas em relação a "lacunas duplicadas”, ou seja, a matérias que não fossem abordadas nem pelo regime das sociedades limitadas, nem tampouco pelas normas típicas das sociedades simples. A disciplina da sociedade anônima representaria, assim, um regime supletivo complementar ao da sociedade simples e, apenas indiretamente, ao da sociedade limitada.

A segunda possível interpretação do parágrafo único do artigo 1.053 propugna, em caso de adoção de tal disciplina pelo contrato social, pela aplicação imediata das normas das sociedades anônimas a todas as questões não diretamente abordadas pelo próprio regime das sociedades limitadas. Desse modo, as normas das sociedades anônimas afastariam e substituiriam as regras das sociedades simples, enquanto regime supletivo das sociedades limitadas.

Esta segunda possibilidade (substituição) parece muito mais adequada do que a primeira, uma vez que a prevalência da complementação de regimes daria ensejo a um indecifrável cipoal normativo de três níveis (normas das sociedades limitadas, complementadas pelo regime das sociedades simples, cujas lacunas comuns seriam supridas pelas regras das 
sociedades anônimas) e esvaziaria o parágrafo único de grande parte de seu sentido. Parece, portanto, mais razoável o entendimento de que a opção pelo regime subsidiário das sociedades anônimas representa uma alternativa excludente do emprego supletivo das regras das sociedades simples.

A adoção da tese da substituição de regimes impõe, todavia, a necessidade de justificar e explicar as diversas remissões diretas a dispositivos relativos às sociedades simples, presentes em artigos pertencentes ao capítulo das sociedades limitadas, como já mencionado acima (por exemplo, remissão do artigo 1.085 ao artigo 1.030). Afinal, como poderia se afirmar que o regime das sociedades anônimas substitui aquele das sociedades simples se, além do disposto no caput do artigo 1.053, persistiriam referências diretas e inderrogáveis ao regime destas últimas?

A melhor resposta a tal questão parece ser a de que as normas das sociedades simples expressamente referidas por dispositivos relativos às sociedades limitadas são apropriadas pelo regime destas, como se dele fossem partes integrantes. Uma vez plasmadas à disciplina da sociedade limitada, tais específicas regras da sociedade simples continuariam aplicáveis mesmo no caso de eleição das normas das sociedades anônimas como regime supletivo $^{23}$. Ou seja, o objetivo de tais remissões diretas seria o de incorporar algumas normas das sociedades simples ao regime da sociedade limitada, justamente para tornar tais regras “imunes” a uma eventual derrogação por parte das normas da sociedade anônima, quando e se eleitas como regime subsidiário.

Ocorre que, mesmo com tais ressalvas, a aceitação da tese da substituição das regras da sociedade simples pelas normas das sociedades anônimas, enquanto regime subsidiário das sociedades limitadas, não resolve o problema de se determinar em cada situação concreta quais dispositivos podem realmente ser aplicados a este último tipo societário.

Existem inúmeros exemplos desse problema. É mais que do evidente que, mesmo em caso de eleição das normas das sociedades anônimas como disciplina suplementar, uma sociedade limitada não poderá nunca abrir seu capital e negociar suas quotas em bolsa. Pode-se argumentar que sua natureza híbrida é também incompatível, por exemplo, com a

${ }^{23}$ H. VERÇOSA, Curso de Direito Comercial, vol. 2, p. 370. 
emissão de debêntures, ainda que com colocação privada, ou com a criação de "quotas preferenciais”. A questão é menos óbvia, porém, quando se discute a possibilidade de emissão de bônus de subscrição. Pode-se indagar também se o acordo de quotistas depositado na sede da sociedade vincula a atuação do presidente de uma assembléia ou reunião de uma sociedade limitada (artigo 118, parágrafo $8^{\circ}$, da Lei n ${ }^{\circ}$ 6.404/76).

Muitas de tais dificuldades já estavam presentes na vigência do Decreto 3.708/19²4 O lacônico regime anterior possuía, contudo, a enorme vantagem de privilegiar a liberdade contratual e a autonomia dos sócios, permitindo que grande parte das dúvidas existentes fosse mitigada por meio da cuidadosa redação do contrato social. De fato, na longa (e nunca definitivamente encerrada) discussão que cercou a interpretação do artigo 18 do Decreto 3.708/19, acabou por prevalecer o entendimento sugerido desde os primeiros anos pelo Professor Waldemar Ferreira, no sentido de que o recurso à lei das sociedades anônimas destinava-se apenas a suprir as lacunas contratuais (do contrato social) e não aquelas legais (regime formado Decreto 3.708/19 somado às normas societárias gerais do antigo Código Comercial de 1850) ${ }^{25}$.

Essa forma de interpretação assegurava evidentemente um espaço privilegiado para autonomia das partes. O Código Civil de 2002, ao contrário, reserva ao contrato social, nos termos do parágrafo único do artigo 1.053, apenas a prerrogativa de eleger o regime supletivo aplicável à sociedade limitada, mas não atribui às disposições contratuais em si o caráter de disciplina subsidiária, concorrente com as normas da sociedade simples ou da sociedade anônima. De conseqüência, tanto o valor das disposições do contrato social quanto a forma de aplicação das normas das sociedades anônimas à sociedade limitada são muito diferentes sob a égide da nova legislação.

\footnotetext{
24 “....ainda que expressamente elejam as partes, no contrato social, a Lei de Sociedades Anônimas, como supletiva, tendem a perdurar as dúvidas que já existiam na anterior vigência do Decreto n. 3.708/19, a respeito de se identificar das regras das sociedades anônimas passíveis de aplicação às limitadas, pois nenhum critério novo é trazido pelo Código Civil de 2002 que possa colaborar para o deslinde da questão." in M. CARVALHOSA, Comentários ao Código Civil - Parte Especial do Direito de Empresa, p. 44.

25 "Como acentua Waldemar Ferreira, citado pelo agravado [...], a sociedade por quotas não é [...] sociedade anonima simplificada. A lei da sociedade anonima absolutamente não é subsidiária da sociedade por quotas. Segundo o mencionado art. 18, ela é apenas subsidiária do contrato de sociedade por quotas, aplicando-se a esta 'no que não for regulado no estatuto social'. A lei da sociedade anonima é supletiva da vontade das partes contratantes da sociedade por quotas, quando possivel a sua aplicação. Mas, não supre a vontade do legislador que estatuiu a sociedade por quotas. Com efeito a sociedade por quotas é regulada pelas normas da lei propria e pelos arts. 300 a 302 do Código Comercial.” STF, Recurso Extraordinário no 16.234-SP, Exmo. Min. Orosimbo Nonato (relator), D.J. 21/09/1950. W. FERREIRA, Instituições de Direito Comercial, vol. 1, p. 391-392.
} 
Sob a nova sistemática, as disposições da lei das sociedades anônimas prevalecem inequivocamente sobre o contrato social ${ }^{26}$. Assim, em princípio, as restrições (e não apenas os instrumentos úteis) constantes da Lei $\mathrm{n}^{0}$ 6.404/76 incidem sobre a sociedade limitada, em caso de adoção de tal disciplina como regime subsidiário. Como resultado, cumpre indagar, apenas como exemplo, se uma sociedade limitada que adote expressamente a regência supletiva das normas das sociedades anônimas pode distribuir lucros entre seus sócios desproporcionalmente à participação detida por cada um deles ou se deve, eventualmente, publicar em jornal de grande circulação suas demonstrações financeiras.

Independentemente do primeiro regime supletivo escolhido pelos sócios, (sociedade simples ou sociedade anônima) pode-se ainda aplicar à sociedade limitada, como regime supletivo secundário, a disciplina das associações, nos termos do parágrafo único do artigo 44 do Código Civil de $2002^{27}$. Tendo em vista, porém, a exígua quantidade de normas que disciplinam as associações (artigos 53 a 61 do Código Civil de 2002), tal remissão genérica possui escassa utilidade prática.

A questão da definição das normas aplicáveis à sociedade limitada torna-se ainda mais complicada quando se toma em consideração a eventual possibilidade ou necessidade de recurso à interpretação analógica. Isso significa que, de fato, poderão ser aplicadas normas das sociedades anônimas mesmo a uma sociedade limitada cujos sócios não tenham utilizado a prerrogativa constante do parágrafo único do artigo 1.053 e na qual prevaleça, portanto, o regime legal supletivo das sociedades simples ${ }^{28}$.

Ademais, Modesto Carvalhosa traz à tona a possibilidade de eleição implícita do regime legal das sociedades anônimas. Com efeito, para o festejado autor, caso o contrato social

\footnotetext{
${ }^{26}$ Em sentido contrário, ou seja, favorável à idéia de que, na hipótese de recurso à faculdade prevista no parágrafo único do artigo 1.053, o contrato social prevalece sobre as disposições legais das sociedades anônimas: “...na presença de contrato social de sociedade limitada do qual conste cláusula de regência supletiva pela lei das S/A, o próprio contrato é a primeira fonte de solução de problemas jurídicos eventualmente enfrentados pelos sócios, seguindo-se - aí, sim - a norma supletiva.” in H. VERÇOSA, Curso de Direito Comercial, vol. 2., p. 371.

27 “....aplicar-se-ão supletivamente às sociedades limitadas primeiro as regras referentes à sociedade simples ou às sociedades anônimas, conforme o caso. E, permanecendo a omissão, buscar-se-á nas disposições relativas às associações a regra supletiva.” in M. CARVALHOSA, Comentários ao Código Civil - Parte Especial do Direito de Empresa, p. 46.

${ }^{28}$ Pode-se citar, como exemplo, o artigo 175 da Lei 6.404/76 que determina duração do exercício social. Questão não abordada diretamente pelo Código Civil de 2002, vide H. VERÇOSA, Curso de Direito Comercial, vol. 2, p. 372
} 
estabeleça, em seu todo, uma disciplina típica das sociedades de capitais (por exemplo, livre transferência de quotas, administração impessoal, etc.), deve aplicar-se à respectiva sociedade o regime das sociedades anônimas, ainda que não adotado expressamente pelo próprio ato constitutivo ${ }^{29}$.

Cumpre recordar, outrossim, que o artigo 983 do Código Civil de 2002 faculta ao sócios de uma sociedade simples, por definição não-empresária, a possibilidade de constituir o novo ente utilizando uma das formas de sociedade empresária. Uma interpretação contrariu sensu da parte final de tal dispositivo sugere que, ao se constituir uma sociedade simples sob um outro tipo societário, aplicam-se todas as disposições típicas da sociedade empresária cujo regime é tomado de empréstimo. A aplicação de tal preceito cria a peculiar possibilidade de se constituir uma sociedade simples (natureza não empresária) sob a forma de sociedade limitada para, em seguida, eleger como regime subsidiário a disciplina das sociedades anônimas ${ }^{30}$. A esse respeito, convém notar que a própria divisão entre as esferas de atividade empresária e não empresária, prevista pelo artigo 966 e por seu parágrafo único, é em certa medida nebulosa.

Em suma, a delimitação e definição das normas aplicáveis à sociedade limitada sob a égide do Código Civil de 2002 é extremamente complexa e permeada por dúvidas interpretativas por quase todos os lados. Definitivamente, o princípio da operabilidade não foi adequadamente prestigiado na elaboração do Livro da Empresa do novo diploma, a despeito das intenções dos autores do respectivo anteprojeto. Não é sem razão que alguns estudiosos referem-se ao sistema de remissões estabelecido pelo Código Civil de 2002 em matéria societária como “imbróglio”31, “dança remissiva”32, ou ainda como “corrida de obstáculos” ou "Frankenstein jurídico”33.

Dentro do cenário de grande incerteza jurídica que assombra a nova sociedade limitada, as regras que consagram expressamente a possibilidade de exclusão do sócio e disciplinam o

\footnotetext{
${ }^{29}$ M. CARVALHOSA, Comentários ao Código Civil - Parte Especial do Direito de Empresa, p. 43-44.

${ }^{30}$ H. VERÇOSA, Curso de Direito Comercial, vol. 2, p. 355.

${ }^{31}$ J. LUCENA, Das Sociedades Limitadas, p. 539.

32 J. LUCENA, Das Sociedades Limitadas, p. 788.

33 “Conforme se verifica, o NCC colocou o intérprete do direito societário no lugar de um jogador de corrida de obstáculos, que deve percorrer a pista em busca de uma saída em infindáveis idas e vindas - tarefa que é inteiramente fruto da péssima técnica legislativa de que se revestiu aquele diploma legal. O resultado na maioria das vezes será um 'Frankenstein jurídico', [...]” in H. VERÇOSA, Curso de Direito Comercial, vol. 2, p. 372.
} 
respectivo procedimento representam uma feliz exceção. O artigo 1.085, que prevê a possibilidade de exclusão extrajudicial, desde que explicitamente prevista pelo contrato social, pertence ao próprio capítulo das sociedades limitadas, de modo que sua aplicação independe do complexo sistema de remissões estabelecido pelo artigo 1.053 e por seu parágrafo único. Além disso, o artigo 1.085 ressalva expressamente a aplicação do artigo 1.030, pertencente ao capítulo das sociedades simples, à sociedade limitada. Assim, mesmo adotando-se a tese da substituição de regimes, como indicado acima, tal remissão direta tem o condão de tornar o artigo 1.030 "parte integrante” da disciplina das sociedades limitadas, de modo que o dispositivo resta válido e aplicável, ainda que os sócios optem pela regência supletiva das normas da sociedade anônima, nos termos do parágrafo único do artigo 1.053.

Ou seja, o artigo 1.085 confirma por si só a possibilidade de exclusão extrajudicial (sujeita sempre à presença de cláusula expressa) e, por meio de remissão direta, assegura também a permanente aplicabilidade da exclusão judicial (independentemente do conteúdo do contrato social), no âmbito das sociedades limitadas.

De qualquer forma, não é possível afirmar que o instituto da exclusão de sócios seja indiferente às incertezas criadas pelo sistema de remissões adotado pelo Livro da Empresa. Ainda que a própria possibilidade legal da exclusão não esteja em jogo, a determinação das regras supletivamente aplicáveis à sociedade limitada é, todavia, primordial ao tema do afastamento de sócios, na medida em que define a esfera de deveres e obrigações atribuíveis aos quotistas em cada situação concreta.

É cediço recordar, nesse sentido, que - ressalvada a exclusão de pleno direito do sócio falido - são as hipóteses de inadimplemento de deveres e obrigações “societárias” que determinarão o campo de incidência da exclusão (facultativa) de sócios. A questão das normas aplicáveis é, outrossim, importante para estabelecer os direitos dos sócios (e, por conseguinte, as correspondentes hipóteses de abuso de direito), bem como os respectivos procedimentos de deliberação em geral. 


\subsection{A Sociedade Limitada entre as Sociedades de Pessoas e de Capitais}

A distinção entre sociedades de pessoas e de capitais reflete os diferentes contextos históricos e econômicos em que surgiram os tipos societários que tradicionalmente melhor representam cada uma de tais categorias. As sociedades de pessoas nasceram no fim do período medieval, como desdobramento inicial do exercício coletivo-familiar de uma atividade comercial, e encontram na sociedade em nome coletivo seu principal protótipo ${ }^{34}$. Já as sociedades de capitais, representadas sobretudos pelas sociedades por ações, são expressão de um período econômico sucessivo.

As sociedades de capitais tiveram origem, de fato, somente séculos depois, com as grandes companhias coloniais estabelecidas durante o período de consolidação das monarquias européias ocidentais. Tais companhias eram instrumentos de financiamento de grandes empreendimentos nacionais e representavam uma verdadeira parceria entre os estados monárquicos e as ascendentes elites burguesas. Estas forneciam o capital necessário às empreitadas coloniais e recebiam em troca dos governos monárquicos o então excepcional privilégio da limitação de responsabilidade ${ }^{35}$.

As principais características definidoras das sociedades de pessoas, presentes em maior ou menor no grau nos diferentes tipos societários que se enquadram em tal categoria, são: (i) a responsabilidade ilimitada e solidária dos sócios, (ii) o poder de administração inerente à qualidade de sócio e (iii) a impossibilidade de transferir a própria participação societária (ou parte dela) a terceiros sem a prévia anuência dos consócios ${ }^{36}$. Tais atributos, ao mesmo tempo, refletem e determinam a grande relevância das qualidades individuais de cada sócio em relação à própria sociedade. De tal característica deriva, como é bem sabido, a denominação deste grupo de tipos societários ${ }^{37}$.

\footnotetext{
${ }^{34}$ F. GALGANO, Lex Mercatoria, p. 45

35 “La società per azioni nasce, nel Seicento, con il carattere di una sorta di 'patto' di volta in volta concluso da gruppi imprenditoriali con il sovrano: gli uni si dichiarano disposti a intraprendere colossali iniziative economiche, quali la colonizzazione delle terre d'oltremare, dalle quali il sovrano si attende l'accrescimento della potenza politica ed economica dello Stato, ed alle quali la nobiltà guarda come ad una nuova e proficua fonte di rendite, ma che per la classe mercantile importano ingenti rischi, a condizione che venga concesso dal sovrano un 'privilegio', l'immunità dall'antico principio della responsabilità illimitata." in F. GALGANO, Lex Mercatoria, p. 79.

${ }^{36}$ F. GALGANO, Diritto Privato, p. 681-682.

37 “La responsabilità illimitata e la correlativa partecipazione all'amministrazione fanno sì che i soci vengano in considerazione, essenzialmente, per le loro qualità personali, date dall'entità del loro patrimonio e dalle loro capacità imprenditoriali. Di qui, appunto, la denominazione comune a questi tre tipi di società [simples,
} 
Em contraposição, os aspectos idiossincráticos das sociedades de capitais são: (i) a atribuição do benefício da limitação da responsabilidade a ao menos uma classe de sócios, (ii) a dissociação entre a qualidade de sócio e o exercício do cargo de administrador e (iii) a plena liberdade de transferir a própria participação na sociedade a terceiros ${ }^{38}$.

A distinção entre sociedades de pessoas e sociedades de capitais é frequentemente objeto de críticas no Brasil, sob o argumento principal de que todas as sociedades exigem a confluência, em maior ou menor medida, da contribuição pessoal de seus sócios e de investimentos materiais ${ }^{39}$. Contudo, a diferenciação entre ambas as categorias segue evidentemente um critério de mera prevalência relativa de determinados traços e não absoluta exclusão de características típicas de uma ou outra categoria. Tal como se verifica em relação a tantos outros critérios e noções jurídicas, tal fato implica uma inegável área de incerteza, mas tal “zona cinzenta” não torna, por si só, a classificação inválida nem a priva de poder explicativo ${ }^{40}$.

No Brasil contemporâneo, em particular, é necessário reconhecer que a divisão entre sociedades de pessoas e de capitais perdeu muito de sua importância prática, uma vez que a inexistência de requisitos de capitalização mínima para as sociedades limitadas e anônimas relegou as principais sociedades de pessoas “puras” a um efetivo abandono e desuso. Por conseguinte, tais tipos societários (sociedade em nome coletivo e em comandita simples) continuam disciplinados em nossa legislação mais em função de inércia histórica do que efetivo atendimento de necessidades reais do mundo empresarial ${ }^{41}$.

em nome coletivo e em comandita simples] quali società di persone...” in F. GALGANO, Diritto Privato, p. 682.

38 “In rapporto alle società di capitali non può dirsi che il nome di imprenditore designa l'attributo di una persona, come nell'impresa individuale, o che esso designa l'attributo spettante a più persone, come nelle società di persone. La figura dell'imprenditore subisce, nelle società di capitali, questa modificazione: ad essa non corrispondono persone, ad essa corrisponde, invece, una impersonale organizzazione collettiva...” in F. GALGANO, Diritto Privato, p. 683-684.

39 Para Egberto Lacerda Teixeira, tal critério de classificação das sociedades seria “falho, inócuo e ilógico", vide E. TEIXEIRA, Das Sociedades por Quotas de Responsabilidade Limitada, p. 24.

40 "Mas, apesar da imprecisão terminológica das expressões usadas para classificar as sociedades como sendo de pessoas ou de capitais - uma vez que todas as sociedades invariavelmente reúnem-se tanto pessoas quanto capitais -, essa classificação se mostra útil para a definição das regras a incidir sobre determinado tipo societário e para a interpretação destas.” in M. CARVALHOSA, Comentários ao Código Civil - Parte Especial do Direito de Empresa, p. 35-36.

${ }^{41}$ H. VERÇOSA, Curso de Direito Comercial, vol. 2, p. 357. 
Além disso, contrariamente a outros sistemas (como a Alemanha e a Itália), a legislação societária brasileira não adota a divisão das sociedades entre sociedades de pessoas e de capitais como critério básico para o reconhecimento da personalidade jurídica. Trata-se, portanto, de uma classificação de cunho prevalentemente doutrinário. Todavia, os conceitos de sociedade de pessoas e sociedade de capitais ainda possuem grande relevância histórica e conceitual e são essenciais para a adequada compreensão da exclusão de sócios.

O instituto da exclusão é, com efeito, típico das sociedades de pessoas, nos mais diversos ordenamentos que o disciplinaram. A única manifestação do remédio da exclusão comumente encontrada entre as sociedades de capitais é a expulsão do sócio remisso, amiúde denominada “caducidade das ações”, quase como que para demarcar a sua diferença em relação ao afastamento dos sócios nas sociedades de pessoas. No sistema jurídico italiano, por exemplo, a exclusão de sócios por outras causas, que não a falta de integralização das próprias quotas, apenas passou a ser possível em relação às società $a$ responsabilità limitata (reconhecidas expressamente como sociedades de capitais) a partir da reforma do Direito Societário promovida em 2003 e, mesmo assim, apenas mediante cláusula expressa constante do estatuto social, nos termos do artigo $2.473 \mathrm{bis}^{42}$.

Isso se deve não somente ao fato de que as sociedades de capital dispõem de outros instrumentos idôneos para tutelar eventuais infrações e abusos dos sócios ${ }^{43}$, mas se explica sobretudo pelos diferentes espaços e oportunidades concedidos pelo ordenamento para o exercício de uma influência pessoal do sócio sobre os rumos do atividade empresarial, em uma ou em outra tipologia societária ${ }^{44}$.

A aplicação do instituto da exclusão pressupõe sempre uma interferência negativa e pessoal do sócio, ou de eventos a ele atinentes, sobre as atividades da sociedade. Mais

\footnotetext{
42 “Nel precedente sistema, infatti, la prevalenza della tutela dell'integrità del capitale sociale si manifestava anche nella mancata previsione di cause di esclusione al di fuori dell'ipotesi del mancato pagamento delle quote di cui al vecchio art. 2477 c.c.” in F. MAGLIULO, Il Recesso e L'Esclusione, p. 296.

${ }^{43}$ Tal como, por exemplo, a suspensão do direito de voto prevista pelo artigo 120 da Lei das Sociedades Anônimas.

44 “....si può ritenere che la mancata previsione di cause di esclusione del socio nella disciplina delle società di capitali sia dovuta esclusivamente alla particolare struttura organizzativa di queste, che sono, per loro peculiare caratteristica, assolutamente insensibili alla vicende personali dei singoli soci; e riesce impossibile immaginare un comportamento del socio o una modificazione dello status personale del socio che possa essere idoneo a creare una situazione tale che appaia preferibile, per poter continuare l'impresa sociale, sacrificare una parte del patrimonio della società.” in G. BOLLINO, Le Cause di Esclusione del Socio nelle Società di Persone e nelle Cooperative, parte I, p. 379.
} 
especificamente e ressalvada as hipóteses de exclusão de pleno direito, tal interferência deve necessariamente assumir a forma de um inadimplemento do excluendo em face da sociedade.

Ocorre que nas sociedades de capitais, a influência e relevância da pessoa do sócio para o sucesso da sociedade é, por definição, restrita. Em tais sociedades, a única conduta ativa exigida do sócio é, em princípio, a integralização da própria participação. A este dever positivo somam-se apenas algumas obrigações genéricas e elementares de não fazer, tais como não exercer o direito de voto em situação de conflito de interesse, não divulgar informações da sociedade, não abusar da posição de controlador, etc., cuja violação, de qualquer modo, já representaria na maioria dos casos um ato ilícito nos termos da legislação não societária.

Em resumo, nas sociedades de capitais, o sócio pode ser um mero prestador de capital, uma figura distante da sociedade e, sobretudo, da atividade empresarial exercida por esta última, limitando consequentemente o âmbito de aplicação do remédio da exclusão.

As implicações da natureza pessoal ou capitalista da sociedade sobre a exclusão de sócio são essenciais para a aplicação de tal instituto à sociedade limitada brasileira, dado o caráter nitidamente híbrido assumido por este tipo societário em nosso ordenamento. Efetivamente, a natureza mista da sociedade limitada, em posição intermediária entre as sociedades de pessoas e de capitais, é uma das poucas certezas cristalinas que se pode colher no labirinto de remissões normativas criado pelo Livro da Empresa do Código Civil de 2002.

Os autores do anteprojeto de lei que resultou no atual Código Civil manifestaram expressamente a intenção de conferir aos quotistas a liberdade de construir o regime interno da sociedade limitada de acordo com as necessidades práticas de cada situação concreta, atribuindo-lhe feições mais próximas às sociedades de pessoas ou às de capitais conforme fosse julgado mais conveniente ${ }^{45}$.

\footnotetext{
45 "O que estamos vendo aqui, e ainda iremos ver a seguir, é a introdução, na estrutura legal da sociedade limitada, de tudo quanto ela pode e deve ter da configuração da anônima. Tudo, mas só esse tudo, e não o 'quanto for aplicável'. O Projeto permite que a sociedade tome o feitio mais pessoal ou mais capitalístico, dentro das possibilidades criadas em relação aos assuntos principais.” in S. MARCONDES, Questões de Direito Comercial, p. 20-21.
} 
Uma análise da sociedade limitada brasileira escorada nos três critérios de classificação anteriormente mencionados (responsabilidade do sócio, administração e transferibilidade da participação) confirma a natureza eminentemente fronteiriça deste tipo societário ${ }^{46}$. Em primeiro, lugar, a responsabilidade dos sócios, na sociedade limitada, é restrita ao valor do capital social, traço típico das sociedades de capitais. Tal preceito, contudo, é temperado pelo fato de que todos os sócios respondem solidariamente pelo capital social não integralizado (artigo 1.052).

Em matéria de administração, admite-se na sociedade limitada a nomeação de administradores não-sócios, mas desde que exista expressa autorização no contrato social. Além disso, tal nomeação estará sempre sujeita a quorum de deliberação diferenciado, correspondente a dois terços dos votos, ou mesmo aprovação unânime, conforme esteja o capital social totalmente integralizado, ou não (artigo 1.061).

No que tange a transferência das quotas, a lei dispõe supletivamente, como regra geral (artigo 1.057), que um sócio pode ceder sua participação (i) livremente a quem já seja quotista e, (ii) salvo oposição de outros quotistas titulares de ao menos um quarto do capital social, a qualquer terceiro não sócio. Trata-se, contudo, de uma norma expressamente dispositiva e nada impede os sócios de estabelecer, por meio do contrato social, (i) a exigência de aprovação unânime para quaisquer cessões de quotas (impondo uma disciplina típica de sociedade de pessoas) ou, ao contrário, (ii) a plena liberdade de cessão da participação societária (aproximando a sociedade do regime aplicável às sociedades anônimas).

Mesmo em outros aspectos menores revela-se a natureza mista da sociedade limitada. O Código Civil de 2002 consagrou, por exemplo, o regime de deliberação assemblear para a sociedade limitada, traço característico das sociedades de capitais. Todavia, a lei permite que tal forma de deliberação seja flexibilizada por meio do regime de "reunião”, cujas regras podem ser fixadas livremente pelo contrato social. Além disso, contando-se com a

46 “...tendo-se originado da necessidade de preenchimento de uma lacuna entre os tipos societários de responsabilidade ilimitada e a sociedade anônima [...] a sociedade limitada já nasceu com esse caráter híbrido, mesclando características tanto de um quanto de outro grupo, ou seja, de sociedade de pessoas e de sociedade de capitais.” in M. CARVALHOSA, Comentários ao Código Civil - Parte Especial do Direito de Empresa, p. 36. 
assinatura de todos os quotistas, tolera-se a mera deliberação escrita, sem a realização de qualquer conclave.

Em relação à possibilidade de expulsão de quotistas, a principal conseqüência do caráter flexível e fronteiriço da sociedade limitada brasileira, somado à relevância da distinção entre sociedades de pessoas e de capitais para esta questão, é que não se pode de antemão traçar uma regra geral sobre o campo de incidência do instituto da exclusão no âmbito de tal tipo societário. A possibilidade e a própria necessidade de aplicação do remédio da exclusão serão determinadas pelas características concretas de cada sociedade limitada. Quanto mais próximo seu regime efetivo for àquele aplicável às sociedades de pessoas puras, mais direta será a sobreposição entre a esfera pessoal do sócio e as atividades da sociedade e, portanto, maior será o espaço para o recurso ao mecanismo da exclusão.

Como exemplo prático, pode-se mencionar a hipótese de exclusão de sócio por incapacidade superveniente, tal como prevista pelo artigo 1.030 caput do Código Civil de 2002. Tal possibilidade faz perfeitamente sentido em relação a empresas de pequeno porte, como o clássico exemplo de uma padaria com poucos empregados, no qual a contribuição pessoal de cada um dos sócios, na forma de trabalho, pode ser essencial para o sucesso do empreendimento. Em tal contexto - como discutido no Capítulo 5, a seguir -, a incapacidade superveniente do quotista pode torná-lo um “peso morto” para a sociedade.

Todavia, nos casos em que o quotista representa pouco mais do que um prestador de capital, não haveria razão para excluir o sócio que venha a se tornar incapaz, uma que vez seu único dever e suas poucas prerrogativas, essencialmente os direitos voto e fiscalização da sociedade, podem, na maioria dos casos, ser perfeitamente atribuídos a um representante legal. 


\section{AS CAUSAS DE EXCLUSÃO}

Como discutido anteriormente, o Código Civil de 2002, na esteira da legislação italiana, estabeleceu hipóteses de exclusão de pleno direito que, nos termos do parágrafo único do artigo 1.030, convivem com os casos de exclusão facultativa, estes mais alinhados com a tradição jurídica brasileira nessa matéria.

Além disso, já se pôde argumentar também que a exclusão do sócio falido representa a única hipótese de exclusão de pleno direito efetivamente aplicável à sociedade limitada. Com efeito, o afastamento de um quotista em função da liquidação de sua participação para satisfação de dívida particular em face de terceiro - a segunda hipótese de "exclusão" de pleno direito, prevista pelo parágrafo único do artigo 1.030 - (i) não representa técnica e propriamente um caso de exclusão e (ii) deixou de ser aplicável às sociedades limitadas com a última reforma do Código de Processo Civil, que passou a admitir a penhorabilidade das quotas de sociedades empresárias (Capítulo 3).

Ao lado da exclusão de pleno direito, o Código Civil de 2002 disciplinou ainda a possibilidade de exclusão facultativa (i) do sócio remisso (artigos 1.058 e 1.004), (ii) do sócio que se torne incapaz ou cometa "falta grave" contra a sociedade (artigo 1.030, caput), bem como - pela via extrajudicial e desde expressamente prevista pelo contrato social - (iii) daquele que cometer “atos de inegável gravidade”, que ponham em risco a continuidade da empresa (artigo 1.085) ${ }^{1}$.

Um fato comum a todas as referidas hipóteses de exclusão, facultativas ou não, é a exigência de uma justa causa, que determine ou autorize a aplicação do remédio da expulsão. Em relação à exclusão de pleno direito, tal causa é prévia e precisamente delimitada (caberia mesmo se dizer “tipificada”) pelo legislador, como não poderia deixar de ser no caso de um instituto que possui natureza de sanção legal e tutela predominantemente o interesse público. A falência do sócio se verifica assim que prolatada a sentença que a declara e o sentido do postulado legal não tem de ser integrado ou complementado pela sociedade, pelos consócios ou pelo juiz. Na exclusão de pleno direito,

\footnotetext{
${ }^{1}$ O artigo 1.006 do Código Civil de 2002, na esteira do artigo 317 do Código Comercial de 1850, prevê ainda a exclusão do sócio que tenha se comprometido a prestar serviços à sociedade. Pelo rigor de tal disposição, cumpre entender que ela é incompatível com a sociedade limitada, tendo aplicação restrita às sociedades simples.
} 
a causa da exclusão é simplesmente um fato ao qual o legislador, em defesa do interesse público, atribuiu determinadas conseqüências.

No que tange as hipóteses de exclusão facultativa, por outro lado, todas as causas previstas pela lei representam alguma forma de inadimplemento das obrigações do sócio, fato que decorre da própria natureza contratual de tal instituto. Duas de tais causas são previamente enunciadas pela lei: (i) a não integralização das quotas e (ii) a incapacidade superveniente. Em relação aos demais casos, o legislador recorre a fórmulas abertas e mais amplas ("falta grave” e “ato de inegável gravidade”), mas que inequivocamente encerram em si a idéia de inadimplemento.

Com efeito, todas as possibilidades de exclusão facultativa de um sócio de uma sociedade limitada estão expressamente condicionadas à verificação de determinados fatos ou eventos que incidem, direta ou indiretamente, sobre o vínculo entre a sociedade e o sócio ou sobre a capacidade deste último de cumprir adequadamente com suas obrigações. A exigência de verificação prévia de justa causa exerce uma função estrutural na aplicação do remédio da exclusão facultativa, porque estabelece um limite claro para o arbítrio da maioria social.

De fato, o caráter "facultativo" da exclusão não significa que a aplicação desta medida extrema esteja submetida ao mero e desimpedido alvedrio dos demais consócios. A faculdade atribuída pela lei à sociedade (exercida por meio de deliberação da maioria social) reside simplesmente na possibilidade de avaliar se, em resposta a determinado e concreto inadimplemento do quotista, a exclusão do sócio inadimplente representa ou não a solução mais adequada aos interesses da sociedade.

A decisão sobre a reação ao inadimplemento em si - seja em preparação à formulação de uma ação judicial, nos termos do artigo 1.030 do Código Civil de 2002, seja no âmbito de processo de exclusão extrajudicial, conforme o artigo 1.085 -, compete exclusivamente à sociedade, por meio de deliberação de seus sócios. Tal deliberação representa uma avaliação econômica e comercial sobre qual é, para a sociedade, o menos grave entre dois males: (i) tolerar a permanência do sócio inadimplente no quadro social ou (ii) suportar a perda econômica decorrente do pagamento dos haveres do excluído. 
Não cabe ao juiz ou árbitro adentrar no mérito de tal decisão específica. A autoridade julgadora pode e deve, porém, controlar a existência do pressuposto fundamental de tal deliberação: a presença da justa causa. Não se verificando grave inadimplemento do sócio, não pode a sociedade deliberar a sua exclusão. Desse modo, o requisito da justa causa circunscreve a discricionariedade da sociedade (na maioria das vezes, da maioria social), em matéria de exclusão, à mera resposta ao inadimplemento. Consoante a precisa lição do Professor Luiz Gastão Paes de Barros Leães, a exigência de uma causa justificada para a admissão da exclusão não é mais do que o “contraponto lógico” do direito do quotista adimplente de manter a qualidade de sócio ${ }^{2}$.

Sujeitar a conservação do status socii ao mero alvedrio dos sócios controladores não seria uma expressão de pragmatismo, mas antes uma expressão de arbitrariedade e exacerbado individualismo. Nesse sentido, não apenas não existe - no âmbito das sociedades limitadas - um direito unilateral à exclusão ad nutum de um quotista, como a cláusula do contrato social que buscasse estatuir tal prerrogativa seria de todo inválida, porque meramente potestativa e, portanto, violadora do artigo 122 do Código Civil de $2002^{3}$.

Além disso, a admissão de um direito de exclusão potestativo (similar à situação de fato prevalente antes da promulgação do Código Civil de 2002) implicaria uma profunda alteração do equilíbrio de forças entre maioria e minoria social e sujeitaria esta última a uma permanente e absoluta situação de insegurança. O resultado não seria outro que não o desestímulo à adoção da sociedade limitada como veículo para a soma de esforços e associação de capitais em torno de projetos comuns.

Em tal cenário, por exemplo, os sócios majoritários teriam perenemente à disposição a possibilidade de excluir, por simples conveniência, consócios que manifestassem a intenção de fiscalizar a sua gestão (possivelmente fraudulenta) dos negócios sociais ou, então, expulsar os quotistas minoritários sempre que despontassem no horizonte promissoras oportunidades de negócios para a sociedade, evitando assim repartir os ganhos

\footnotetext{
2 “....a exigência de causa justificada para operar o afastamento compulsório de sócio prevaricador, constante da lei, é, na verdade, o contraponto lógico do direito do sócio de permanecer na sociedade, enquanto cumprir pontualmente os deveres sociais a que se comprometeu." in L. LEÃES, Exclusão Extrajudicial de Sócio em Sociedade por Quotas, p. 89.

${ }^{3}$ M. REALE, A Exclusão de Sócio das Sociedades e o Registro do Comércio, p. 293. "Va precisato innanzi tutto che, per opinione pacifica, non è consentito attribuire alla maggioranza dei soci un diritto assoluto di esclusione, nel senso di collegare l'esclusione stessa a una decisione arbitraria e insindacabile." in V. BUONOCORE, G. CASTELLANO e R. COSTI, Società di Persone, p. 1139.
} 
com estes últimos ${ }^{4}$. Os potenciais quotistas minoritários, sabendo-se, portanto, permanentemente sujeitos à expulsão sumária, teriam poucos incentivos para participar do empreendimento em questão.

Pode-se sempre contra-argumentar, afirmando que eventuais injustiças e abusos verificados no exercício de um hipotético direito incondicional de exclusão seriam passíveis de reparação por meio da apuração de haveres do sócio excluído e reparação dos danos por ele ilegitimamente sofridos.

Entretanto, tal posição significaria, em termos práticos, um grave dano ao princípio majoritário no âmbito das sociedades limitadas e um parcial retorno (ou melhor, grave retrocesso) ao princípio da unanimidade ${ }^{5}$. Isso porque os minoritários estariam sempre premidos a não discordar dos sócios controladores, sob pena de serem sumariamente ejetados da sociedade. A principal diferença é que, neste caso, a reiterada impossibilidade de atingir o consenso não levaria mais à dissolução total da sociedade, tal como ocorria no passado - resultado com óbvias desvantagens, mas que ao menos compelia todos os sócios a buscarem ativamente um entendimento -, porém premiaria a eventual intransigência do sócio majoritário com o afastamento do minoritário.

Nesse sentido, a exclusão de um sócio, tanto de pleno direito como por inadimplemento, deve estar sempre calcada em uma justa causa prevista pela lei, ou então, não incompatível com está última e explicitamente estabelecida no contrato social. Uma vez reafirmada a inafastável necessidade da causa justificada, torna-se necessário delimitar tal conceito. Nas hipóteses de exclusão de pleno direito, que representam a mera implementação de um comando legal, a justa causa é delimitada pelo próprio legislador, como discutido anteriormente.

\footnotetext{
4 "Se, por exemplo, em uma sociedade se verificar uma formidável valorização do patrimônio social, por obra e iniciativa de um sócio, poderão os outros - os menos ativos e criadores - combinar a sua exclusão, para despedi-lo com a vantagem de lhe pagar apenas o capital acrescido do lucro apurado no balanço...” in M. REALE, A Exclusão de Sócio das Sociedades e o Registro do Comércio, p. 292.

${ }^{5}$ Em comentário ao notório Acórdão do STJ RESP n. 66.530, José Edwaldo Tavares Borba asseverou que "O poder atribuído por esse acórdão à maioria constitui, na verdade, um instrumento de arbítrio de todo indesejável, e manifestamente contrário ao princípio majoritário, cujo corolário, considerada a sua base democrática, é o respeito à minoria e aos seus direitos, inclusive o de fazer oposição.” in J. BORBA, Direito Societário, p. 144. De qualquer forma, a questão é aprofundada no próximo tópico, que se dedica à análise da ruptura da affectio societatis como causa de exclusão de sócio.
} 
Em relação à exclusão facultativa, por outro lado, tratando-se de uma manifestação específica do princípio da resolução do contrato por inadimplemento, deve se demonstrar a ocorrência da violação das obrigações do sócio. Não obstante, não se trata de um inadimplemento qualquer. O primeiro aspecto, presente em todos os casos de exclusão facultativa do sócio, é que a obrigação inadimplida deve possuir natureza societária ${ }^{6}$. Ou seja, o inadimplemento deve dizer respeito diretamente ao feixe de direitos e obrigações que se estabelece no âmbito do contrato plurilateral de sociedade.

Ocorre recordar que a exclusão facultativa consiste, efetivamente, em instrumento de natureza contratual que tem por finalidade a conservação da empresa. É por tal razão que a titular do direito de exclusão é a própria sociedade e ela deve ser a parte diretamente lesada pelo inadimplemento do sócio, como condição para que o instituto seja aplicável. Nesse sentido, a exclusão não pode ser invocada como ferramenta para tutelar o inadimplemento de obrigações particulares de um sócio em face de outro consócio.

Mesmo em relação à sociedade, o âmbito de aplicação do instituto da exclusão de sócio é, em princípio, delimitado pelos deveres que derivam da própria qualidade de sócio. Se a obrigação inadimplida deriva de um contrato bilateral entre sócio e sociedade, mas absolutamente estranho ao vínculo societário, a prerrogativa à disposição da sociedade seria, em princípio, a tradicional resolução do contrato bilateral por inadimplemento (disciplinada pelo artigo 475 do Código Civil de 2002), e não a exclusão facultativa de sócio, variante societária do mesmo instituto.

É o caso, por exemplo, do sócio que adquire um serviço da sociedade sem qualquer privilégio ou favorecimento, nas mesmas condições em que tal atividade é disponibilizada aos clientes regulares. Em caso de não pagamento, a sociedade pode cessar o fornecimento do serviço, cobrar o valor em atraso, bem como exigir ressarcimento pelos danos sofridos, mas não necessariamente estará autorizada a excluir o quotista em questão. Tal aspecto é extremamente relevante para a avaliação de eventuais desvios de conduto do sócioadministrador. Como se argumenta a seguir, o inadimplemento de uma obrigação tipicamente bilateral para com a sociedade apenas pode ensejar a exclusão do sócio se,

\footnotetext{
6 "Il riferimento dell'art. 2286 alle obbligazioni sociali rende irrilevante l'inadempimento di obbligazioni che sociali non siano." (grifo no original) in V. BUONOCORE, G. CASTELLANO e R. COSTI, Società di Persone, p. 1136.
} 
simultaneamente, caracterizar a violação de uma obrigação societária acessória, tal como o dever de lealdade.

É importante ressaltar que, a despeito da função estrutural desempenhada pela noção de inadimplemento na exclusão facultativa do sócio, a aplicação do remédio da expulsão prescinde absolutamente da existência ou demonstração de culpa ou dolo por parte do excluendo. A função do instituto da exclusão facultativa de sócios é resguardar a atividade empresarial de fatos danosos atinentes à pessoa de um dos sócios, tenham ou origem na imprudência, negligência ou imperícia do próprio excluendo ${ }^{7}$.

A própria referência expressa à incapacidade superveniente do sócio como possível causa de exclusão evidencia o fato de que o mero descumprimento de uma obrigação (em tal caso, dever de colaboração) justifica por si só a possibilidade de expulsão. Com efeito, é perfeitamente plausível que a incapacidade do sócio resulte de acidente ou moléstia grave totalmente desvinculadas de qualquer elemento de culpa. Uma vez que a exclusão facultativa tem a natureza de prerrogativa contratual - destinada à tutela da empresa e da sociedade - e não de pena ou sanção, é efetivamente razoável e coerente que os aspectos volitivos que cercam o inadimplemento do sócio excluendo não exerçam uma função central para a aplicação do instituto ${ }^{8}$.

A demonstração de culpa é um elemento relevante simplesmente (i) para a delimitação da eventual extensão do dever do sócio excluendo de indenizar a sociedade (com o reconhecimento de uma responsabilidade aquiliana que se soma àquela contratual) ${ }^{9}$ e (ii) para a caracterização da gravidade da conduta do quotista, nos termos dos artigos 1.030, caput, e 1.085 do Código Civil de 2002.

Como já mencionado anteriormente, o Código Civil de 2002 delimitou previamente apenas duas hipóteses de exclusão facultativa no âmbito das sociedades limitadas, a não integralização das quotas e a incapacidade superveniente do sócio. Para tutelar as demais

\footnotetext{
7 “...embora o não-cumprimento do dever de colaboração decorra de vicissitudes pessoais, sem que tenha o sócio obrado com culpa (interdição, inabilitação, impossibilidade física, etc.), ainda assim é se pronunciar a exclusão, se a falta de colaboração pode pôr em risco a prossecução das atividades sociais na busca do objetivo comum.” in J. LUCENA, Das Sociedades Limitadas, p. 708.

${ }^{8}$ A. DALMARTELLO, L’Esclusione del Socio dalle Società Commerciali, p. 115.

9 "A distinção entre o sócio culpado e o não-culpado há de ser feita somente para o efeito de responsabilidade por perdas e danos a que fica sujeito o socius rixosus." in J. LUCENA, Das Sociedades Limitadas, p. 709.
} 
possibilidades de inadimplemento do quotista, o legislador de 2002 fez apenas referências genéricas e amplas a “falta grave” (artigo 1.030, caput) e a "atos de inegável gravidade” (artigo 1.085).

Trata-se de uma opção legislativa acertada, pois nenhum rol pré-determinado de hipóteses de inadimplemento seria capaz de abarcar adequadamente todo o espectro de possibilidades concretas de grave dano à atividades da sociedade em razão de atos ou omissões dos sócios ${ }^{10}$. Tais hipóteses de inadimplemento serão tão variadas quanto forem os usos práticos dados à sociedade limitada. Tendo em vista a ampla disseminação deste tipo societário no Brasil, empregado tanto por pequenas empresas quanto para a implementação de grandes empreendimentos, a lei não poderia efetivamente impor de antemão uma lista numerus clausus de casos que autorizassem a expulsão de um sócio.

Ocorre, entretanto, que a contrapartida natural e inevitável à maior flexibilidade oferecida pela norma consiste em um proporcional aumento das dificuldades enfrentadas pelo intérprete na aplicação da lei ao caso concreto.

A primeira questão a ser vencida, nesse sentido, é a existência de eventual diferença de significado entre os conceitos de (i) “falta grave”, estabelecido pelo caput do artigo 1.030 como requisito para a exclusão judicial e (ii) “atos de inegável gravidade”, cuja verificação é uma das condições essenciais para a admissão da exclusão extrajudicial do sócio, nos termos do artigo 1.085 .

O elemento que salta aos olhos na análise de ambas as mencionadas expressões é a exigência de "gravidade”. A exclusão representa sempre uma medida drástica que, na maioria dos casos, impõe à sociedade uma descapitalização extemporânea, decorrente da necessidade de apurar e pagar os haveres do excluído. Trata-se, portanto, de um remédio sempre "amargo", que deve ser empregado com parcimônia. A exclusão não deve ser

\footnotetext{
10 "Não se consegue contornar o mal resultante dos erros judiciários, com especificar às aplicações práticas dos dispositivos. Quanto mais pródiga em minúcias a lei, quanto mais particularista, maior o número de interrogações que levanta, de litígios que sugere. Deve procurar suprir as faltas dos Códigos, reveladas pela prática, ou corrigir as conclusões prejudiciais a que chegou a jurisprudência: porém com a mais discreta reserva, evitando perder-se nos meandros da casuística, da qual resultaria multiplicar as causas de dúvida e, portanto, agravar a insegurança jurídica." (sem grifo no original) in C. MAXIMILIANO, Hermenêutica e Aplicação do Direito, p. 48.
} 
invocada como solução ao inadimplemento insignificante ou que possa ser tutelado com igual eficácia por meio do emprego de instrumentos mais brandos.

Para Modesto Carvalhosa, as expressões usadas pelo artigo 1.030 e pelo artigo 1.085 do Código Civil de 2002 podem ser substancialmente tomadas como sinônimas ${ }^{11}$. É necessário, entretanto, ter em consideração as diferenças existentes entre os procedimentos de exclusão judicial e extrajudicial. Como se argumenta de forma mais detalhada no Capítulo 6, a seguir, a remissão direta do artigo 1.085 ao artigo 1.030 implica que a exclusão extrajudicial prevista no capítulo dedicado às sociedades limitadas não substitui a exclusão judicial, disciplinada no capítulo das sociedades simples, nem exclui sua aplicação àquele tipo societário. Ou seja, no âmbito da sociedade limitada, ambos os procedimentos convivem em paralelo.

A admissão da exclusão extrajudicial representa a atribuição de uma prerrogativa extremamente relevante para a maioria social: o poder de determinar autonomamente a exclusão de um sócio, transferindo ao quotista excluído o ônus de recorrer à autoridade judicial caso se sinta lesado. É em razão do peso e do caráter excepcional de tal conferência de poder que a lei impõe a existência de cláusula expressa, prévia notificação do excluendo e convocação de assembléia ou reunião especial, como requisitos essenciais para admissão da exclusão extrajudicial.

Nessa esteira, é perfeitamente plausível admitir que o legislador, também no que toca a questão da justa causa, tenha sido mais rigoroso em relação à exclusão extrajudicial do que foi ao disciplinar o procedimento judicial. Sempre que não for cabível o procedimento extrajudicial, os sócios poderão recorrer diretamente à via judicial para pleitear a exclusão de um consócio. Nesse sentido, parece lógico que o campo para a aplicação da exclusão extrajudicial seja mais estreito do aquele reservado pela lei para a alternativa judicial, que melhor garante e preserva os direitos do excluendo.

\footnotetext{
11 “A 'falta grave' no cumprimento das obrigações do sócio a que se refere o art. 1.030 e o 'ato de inegável gravidade' referido no art. 1.085 podem ser tomados como sinônimos, querendo ambas as expressões significar a violação da lei ou do contrato social pelo sócio, ou sua ação ou omissão, que a provoque a quebra da affectio societatis.” in M. CARVALHOSA, Comentários ao Código Civil - Parte Especial do Direito de Empresa, p. 323.
} 
Caso contrário, não haveria razão para o legislador adotar, em um mesmo diploma e em dois artigos que tratam do mesmo tema geral (um até mesmo fazendo referência explícita ao outro), fórmulas tão distintas. A justa causa estipulada pelo artigo 1.085 parece afastarse do conceito previsto no artigo 1.030 (caput) em dois aspectos. O primeiro está no emprego da expressão "atos”, que exprime a idéia de conduta ativa, ou seja, prática comissiva e não simples omissão ou negligência.

Mais importante, contudo, é o segundo aspecto, ou seja, a qualificação aduzida pelo artigo 1.085 ao requisito da gravidade. Enquanto o artigo 1.030 refere-se simplesmente a "falta grave” no cumprimento das obrigações do sócio, o artigo 1.085 especifica que a exclusão extrajudicial apenas é possível nos casos em que a conduta do excluendo esteja dotada de “inegável gravidade” e represente ameaça para a própria continuidade da atividade empresarial.

O primeiro critério ("falta grave”) transmite apenas a idéia de "não insignificância”, enquanto o segundo expressamente indica que a justa causa em questão deve comportar um risco à sobrevivência da empresa. Parece haver uma inequívoca diferença de grau entre ambos os critérios, que aconselha maior rigor e prudência na admissão da exclusão extrajudicial.

Uma vez que o instituto da exclusão facultativa tem por pressuposto o inadimplemento do sócio, o segundo e mais crítico aspecto da aplicação do instituto reside precisamente na identificação das obrigações acessórias atribuíveis ao quotista, ou seja, a delimitação dos deveres impostos pela lei ou pelo contrato social, para além da mera integralização das próprias quotas (hipótese expressamente tutelada pelo artigo 1.004 do Código Civil de 2002).

A extensão e preciso conteúdo das obrigações acessórias do sócio representam uma matéria, por si só, delicada e nebulosa, em qualquer sistema jurídico e em relação a qualquer tipo societário. No que tange a sociedade limitada brasileira, todavia, tal questão é particularmente delicada, em função de duas razões principais.

A primeira, como indicado no capítulo anterior, diz respeito à natureza híbrida da sociedade limitada no Direito brasileiro. Não dispondo a lei de uma divisão expressa entre 
os conceitos de sociedade de pessoas e de capitais, a sociedade limitada está perdida em uma espécie de zona cinzenta entre dois extremos, não restando claro se, no silêncio do contrato social, pode-se intuir uma colaboração ativa e pessoal dos quotistas - traço típico das sociedades de pessoas - ou se deve presumir que estes últimos são meros prestadores de capital - como nas sociedades de capitais.

Muito mais grave, porém, é a forma como se desenvolveu e foi aplicada no país a tese da ruptura da affectio societatis, como causa supostamente suficiente para justificar a exclusão de um sócio. A noção de que a affectio societatis - apesar de todas as imprecisões que rondam tal conceito, nunca adequadamente delimitado - foi acriticamente acolhida no Brasil, (i) como um fundamento do contrato de sociedade e (ii) como um elemento essencial ao sucesso da empresa. Desse modo, alimentou-se uma tendência da doutrina e da jurisprudência de tomar a ruptura da affectio societatis como justificativa universal para o recurso à exclusão de sócios, suplantando a efetiva discussão de condutas ou omissões concretas que se ajustassem ao conceito de inadimplemento grave.

Tratando-se de uma questão essencial à efetividade do requisito da justa causa e dado que se defende neste trabalho posição contrária à vasta maioria dos estudos realizados no Brasil sobre a questão, convém dedicar um tópico especificamente à crítica do conceito de affectio societatis, antes de adentrar na discussão dos deveres concretos dos sócios. Em seguida, para fins da presente análise, tais deveres são subdivididos nas categorias gerais de “dever de colaboração” e “dever de lealdade”.

\subsection{Crítica à Doutrina do Rompimento da Affectio Societatis}

A origem do conceito de affectio societatis remonta ao período romano, atribuindo-se a autoria de tal expressão a Ulpiano ${ }^{12}$. Desde sua formulação inicial, tal conceito teria servido como ferramenta para a diferenciação da societas de outras figuras jurídicas similares $^{13}$. De fato, há muito tempo os doutrinadores já haviam intuído a especialidade do

\footnotetext{
12 “Communiter autem res agi potest etiam citra societatem, ut puta quum non affectione societatis incidimus in communionem: ut evenit in re duobus legata: item si a duobus empta res sit.” apud (nota de rodapé) R. REQUIÃO, A Preservação da Sociedade Comercial pela Exclusão de Sócio, p. 38.

13 “Ao determinar as hipóteses que ensejavam a ação pro socio e aquelas em que unicamente podia caber a praescriptio verbis, e para solucionar quando cabia uma ou outra ação, reputava necessário investigar se as partes tinham ou não a intenção de constituir uma sociedade, investigação esta por ele [Ulpiano] designada com as locuções affectio societatis ou animus contrahendae societatis.” in C. LEITE JR., Affectio Societatis: na Sociedade Civil e na Sociedade Simples, p. 89.
} 
contrato de sociedade, cuja diferença em relação aos demais contratos sempre se demonstrou muito maior do que a existente reciprocamente entre quaisquer duas outras figuras contratuais ${ }^{14}$.

Porém, tanto a construção de uma definição precisa do conceito de sociedade, quanto seu devido enquadramento no campo do direito das obrigações exigiam critérios igualmente rigorosos, os quais a diferenciassem não apenas dos demais contratos, mas também de situações jurídicas assemelhadas, em especial da comunhão de bens ${ }^{15}$. A diferenciação entre ambas as situações (sociedade e comunhão) tornava-se especialmente desafiadora e delicada quando a comunhão recaía sobre bens produtivos ${ }^{16}$.

Em termos simplistas, pode-se dizer que se formaram duas principais correntes doutrinárias para a explicação de tal distinção, cada qual baseada em um elemento-chave específico. A primeira delas, prevalente nos países germânicos ${ }^{17}$ e mais tarde também na Itália, identificou no fim ou objetivo comum de exercer determinada atividade econômica, presente em qualquer contrato de sociedade, o aspecto essencial e definidor dessa figura jurídica. O direcionamento dos esforços dos membros da sociedade no sentido da realização do objetivo social é, assim, elevado à condição de chave para a leitura e interpretação de todos os vínculos entre os sócios e destes com a sociedade. Enquanto na comunhão, a titularidade conjunta dos bens (produtivos ou não) é o próprio fim e resultado pretendido ou esperado da relação jurídica, na sociedade ela é apenas meio ou instrumento para o exercício da atividade produtiva ${ }^{18}$.

Na França, por outro lado, a maioria da doutrina optou por resgatar como elemento típico e identificador da sociedade a idéia romana de affectio societatis, entendida como uma

${ }^{14}$ P. FERRO-LUZZI, I Contratti Associativi, p. 2.

15 "La distinzione della società dalle figure affini deve prendere le mosse dalla distinzione fra società e comunione. La quale sembra intuitiva: nella comunione c'è un semplice rapporto di condominio, una mera contitolarità di beni, nella società c'è un contratto per l'esercizio di un'attività economica sia pure a mezzo di beni comuni.” in F. FERRARA JR., F. CORSI, Gli Imprenditori e le Società, p. 220.

16 "La distinzione tuttavia appare meno semplice a proposito delle cose produttive, il cui godimento suppone l'esercizio di un'attività.” in F. FERRARA JR., F. CORSI, Gli Imprenditori e le Società, p. 221.

17 A noção de "gemeinsamen Zweck" (objetivo comum) é, por exemplo, um elemento expressamente consagrado da definição legal de sociedade constante do parágrafo 705 do Código Civil Alemão (BGB).

18 "Nella prima [comunhão] la contitolarità è fine a sé stessa, nella seconda [sociedade] è in funzione di un'attività da svolgere. Alla comunione corrisponde un semplice godimento, alla società un guadagno. La prima ha per oggetto la percezione di utilità prodotte direttamente o indirettamente da un bene, la seconda ha una funzione creatrice di nuove utilità." e ainda "[...] l'attività qui [comunhão] è in funzione del godimento, in quanto è diretta a renderlo possibile, e dunque non ha rilevanza propria." (grifo no original) in F. FERRARA JR., F. CORSI, Gli Imprenditori e le Società, respectivamente p. 220 e 221. 
vontade de colaboração ativa, resultante de vínculos de estima e confiança recíproca entre os sócios ${ }^{19}$. Em contraposição à comunhão, onde haveria uma passiva e, no mais das vezes, transitória fruição conjunta da coisa tida em co-propriedade, existiria na sociedade um sentimento recíproco de participação e cooperação, bem como um senso de permanência.

A distinção entre as duas concepções pode parecer sutil, uma vez que ambas envolvem, em essência, o propósito de unir esforços e capitais para a realização de atividade produtiva. Existem, contudo, profundas diferenças conceituais que as separam. De fato, na visão italiana e germânica, o fim comum relevante é o da sociedade e não dos sócios. Não se trata de uma vontade pessoal e mutável, mas de um objetivo comum que, no mais das vezes, é inclusive delimitado e fixado por escrito no contrato social. O fato principal, de natureza também objetiva, é a estrutura específica do negócio jurídico, em que os direitos e obrigações dos sócios são focados na direção de um centro comum, e não contrapostos.

O elemento da affectio societatis, ao revés, corresponde a um volúvel estado de ânimo e às impressões pessoais de cada sócio, bem como aos seus sentimentos em relação aos seus consócios. A concepção francesa de sociedade - ao tomar a affectio societatis como um de seus pilares centrais - está, portanto, eivada de uma evidente carga de subjetividade e incerteza. Tal visão traduz adequadamente as características da sociedade em nome coletivo embrionária do período medieval, verdadeira continuação econômica de vínculos familiares, mas demonstra-se em grande medida incompatível com a sociedade empresarial moderna, um instrumento absolutamente pragmático e frequentemente impessoal de especulação e busca de ganhos ${ }^{20}$.

Com efeito, a preferência pela idéia de fim comum, em lugar da adoção da doutrina da affectio societatis, representou um dos principais elementos que permitiram à doutrina

\footnotetext{
19 “O dever de colaboração faz parte do contrato de sociedade, é elemento da affectio societatis, definida por Pic como a 'vontade de colaboração consciente, igualitária de todos os contraentes em vista da realização de um lucro a dividir.”' in S. LATORRACA, Exclusão de Sócios nas Sociedades por Quotas, p. 11. Rubens Requião afirmava ainda que: "Podemos, portanto, fixar na confiança mútua, ou na mútua estima, como diz Thaller, o elo fundamental que se encontra nas raízes históricas e naturais das sociedades mercantis, que nelas se aferra como elemento imprescindível e intrínseco. Êsse elemento, convém repetir, é natural e essencial. Sem êle a sociedade não pode constituir-se. Ulpiano batizara êsse elo afetivo pela expressão universalmente consagrada que com perfeição o traduz - 'affectio societatis."' (grifo no original) in R. REQUIÃO, A Preservação da Sociedade Comercial pela Exclusão de Sócio, p. 37-38.

20 "Ma quelle idee [existência de affrattatio entre os sócios] devono ritenersi ormai tramontate e superate. La società, e particolarmente la società commerciale, è entrata oggimai nel novero degli affari meramente speculativi e patrimoniali, e l'aspetto religioso e morale del vincolo si è totalmente perduto.” in A. DALMARTELLO, L'Esclusione dei Soci dalle Società Commerciali, p. 48.
} 
italiana avançar muito mais do que a francesa na formulação de uma adequada explicação para a natureza do contrato de sociedade e suas especificidades ${ }^{21}$. A noção de objeto ou fim comum consiste efetivamente em uma das bases para a reformulação do Direito das Obrigações, a qual permitiu aos estudiosos italianos absorver com sucesso as críticas levantadas pelos partidários da visão institucionalista da sociedade e também pelos defensores das teorias do acordo ou do ato-complexo (Gesamtakt), por meio do reconhecimento da separação dos contratos em duas categorias: contratos bilaterais ou de escambo, de um lado, e contratos plurilaterais ou associativos, do outro ${ }^{22}$.

No Brasil, porém, a idéia de affectio societatis acabou por prevalecer como o elemento essencial e definidor do contrato de sociedade. Conforme o relato de Hernani Estrella, José da Silva Lisboa (o Visconde de Cayru) teria, ainda em 1798, recorrido aos fraternais vínculos de amizade e confiança que deveriam existir entre os sócios, para distinguir a sociedade de figuras como a comunhão e o consórcio ${ }^{23}$. No mesmo sentido, mesmo que de forma mais elaborada e refletindo o desenvolvimento doutrinário verificado no período, manifestaram-se Clóvis Bevilacqua e Washington de Barros Monteiro ${ }^{24}$.

\footnotetext{
21 “È d'altro canto meno avvertita [na doutrina francesa] la sussistenza di un netto distacco del contratto di società dai restanti contratti, o, quando ciò accade, è frequente il ricorso per caratterizzarlo all'affectio societatis. La teoria dell'affectio societatis - quale che fosse il valore che poteva avere in diritto romano assorbe in tale orientamento [França] una parte della problematica che in Germania viene affrontata trattando dello scopo comune. Una importante differenza tuttavia sussiste. In effetti facendosi capo ad un' 'affectio', un'intenzione propria dei contraenti, anziché ad un dato che qualifica l'affare incidendo sul rapporto fra le prestazioni, ed assume così un valore almeno tendenzialmente oggettivo, diviene ancora più difficile di quanto non fosse per la dottrina tedesca fissare la portata dell'elemento, di cui si avverte tutta l'ambiguità.” (sem grifo no original) in P. FERRO-LUZZI, I Contratti Associativi, p. 13-14.

${ }^{22}$ P. FERRO-LUZZI, I Contratti Associativi, p. 22.

23 “No Capítulo XXII, em que [José da Silva Lisboa] se ocupou das sociedades mercantis, cuidou de distingui-las do simples consórcio ou da mera comunhão, fazendo-o, parece, pela relevância atribuída ao caráter convencional explícito, em que se convola a verdadeira sociedade. Ditando-lhe as regras capitais, reguladoras dos direitos e obrigações dos sócios, pôs de início em relêvo: 'As sociedades se contraem na confiança da amizade de mais pura e recíproca boa fé dos sócios; e por isso os sócios se consideram mùtuamente como irmãos; e se algum é compreendido e condenado em dolo, é notado de infâmia.'” (sem grifo no original) in H. ESTRELLA, Apuração dos Haveres de Sócio, p. 27.

${ }^{24}$ Para Clóvis Bevilacqua "a sociedade distingue-se da comunhão seja esta convencional ou incidente. Em uma como na outra, há um ou vários bens que pertencem, conjunta ou simultaneamente, a mais de uma pessoa, porém, na sociedade há affectio societatis, que falta à comunhão, isto é, na sociedade há cooperação e o sentimento de que o trabalho de um, dentro da sociedade, reverte em proveito de todos." Washington de Barros Monteiro, de outro lado, afirmou que "Urge, porém, não confundir sociedade com simples comunhão. Em ambas, existe um ou mais bens que pertencem, conjunta e simultaneamente, a mais de uma pessoa. Distinguem-se no entanto, porque na sociedade presente se acha a affectio societatis, isto é, traço de união, o vínculo de colaboração, o sentimento de que o trabalho de um, dentro da sociedade, reverte para o proveito de todos, enquanto na simples comunhão não entre esse elemento em linha de conta.” (sem grifo no original) ambas as citações apud C. LEITE JR., Affectio Societatis: na Sociedade Civil e na Sociedade Simples, p. 89.
} 
É interessante notar que, a despeito da posterior ampla aceitação da teoria do contrato plurilateral no país, na esteira da importantíssima influência do Professor Tullio Ascarelli $^{25}$, a doutrina da affectio societatis não foi sobrepujada e nem tampouco perdeu força. Desse modo, convivem em nosso sistema, por vezes de modo problemático, duas linhas teóricas diversas para a justificação do contrato de sociedade como figura jurídica autônoma.

De qualquer modo, a persistência da teoria da affectio societatis no Brasil não representa em si o mais grave problema para o tema da exclusão de sócios. A principal dificuldade reside, efetivamente, na forma extremada com que o referido conceito foi recepcionado e tem sido, até os dias de hoje, aplicado no país. Ao invés de ser tomada como elemento ou postulado teórico de descrição do contrato de sociedade em sua formação inicial, em sua gênese, a affectio societatis foi elevada a requisito fático permanente, necessário para a própria preservação da existência da sociedade ${ }^{26}$, ou ao menos para a manutenção de um determinado quadro de sócios.

Como resultado, atribuiu-se a cada um dos sócios um perene direito potestativo de decretar o fim do vínculo societário, ao simplesmente declarar inexistente o consenso que originalmente levou os consócios a constituírem a sociedade. Dessa maneira, em nosso ordenamento, aproximou-se em termos práticos o contrato de sociedade a negócios jurídicos sujeitos à vontade continuativa de todas as partes, tal como o mandato - no qual prevalece a presunção de gratuidade - ou mesmo a instituições nas quais o aspecto moral e afetivo sobrepuja o patrimonial, tal como, por exemplo, o casamento e a união estável ${ }^{27}$.

\footnotetext{
25 "Creio que a solução do problema possa ser encontrada distinguindo-se na categoria dos contratos uma subespécie que poder-se-ia denominar a de contrato plurilateral, levando em conta seus característicos formais.” (sem grifo no original) in T. ASCARELLI, O Contrato Plurilateral, p. 256. H. VERÇOSA, Curso de Direito Comercial, Vol. 2, p. 48-49.

${ }^{26}$ "Ao cessar a 'affectio societatis', extingue-se a sociedade." (grifo no original) in R. REQUIÃO, A Preservação da Sociedade Comercial pela Exclusão de Sócio, p. 40.

${ }^{27}$ A este respeito, Arturo Dalmartello já ponderava que “...il successivo venir meno del consenso è giuridicamente efficace e rilevante in quei rapporti, noti specialmente nel diritto romano e particolarmente studiati dal BONFANTE, 'che esigono una volontà continua, perpetua, che producono effetti finché questa volontà dura e cessano di produrli, vale a dire cessano di esistere allorché la volontà cessa'. Può dirsi che la società (e particolarmente la società commerciale) sia uno di tali rapporti? E che, quindi, il non voler più avere rapporti di società con il socio colpito da minorazione personale sia la semplice e sufficiente spiegazione delle regole di cui ricerchiamo la ratio? Non lo credo. [...] Evidentemente perciò, non si può far capo al semplice venir meno dell'affectio societatis, per spiegare le regole di cui andiamo cercando il fondamento." (grifo no original) in A. DALMARTELLO, L'Esclusione dei Soci dalle Società Commerciali, p. 89.
} 
No campo da exclusão, como já discutido anteriormente, esta interpretação do conceito de affectio societatis, e das conseqüências de seu rompimento, criou espaço para a arbitrariedade dos sócios majoritários, sempre sob o argumento de fundo de que "basta a desinteligência entre os sócios para gerar a exclusão de um deles, independentemente de previsão contratual ou de pronunciamento judicial"28.

Nesse sentido, o remédio da exclusão de sócio, que surgira com o fim precípuo de trazer estabilidade e permanência à sociedade, acabou por se tornar - orientado pelo mesmo individualismo herdado do período romano que antes buscara combater - um instrumento para a expulsão ad nutum de sócios. Por outro lado, do ponto de vista do minoritário recalcitrante, o apelo ao rompimento da affectio societatis representava uma oportunidade sempre presente para retirar-se da sociedade extemporaneamente, não apenas sem estar amparado em justa causa como recebendo seus haveres em valor integral. Não é por outra razão que o artigo 15 do revogado Decreto 3.708/19, que tratava do direito de recesso e previa o inadequado critério contábil (último balanço aprovado) para a apuração de haveres, já havia há muito caído em completo desuso.

Além de promover a instabilidade dos vínculos societários, o modo como a jurisprudência brasileira aplicou a doutrina do rompimento da affectio societatis também representou, em inúmeras ocasiões, um grave obstáculo para a investigação de condutas concretas dos sócios lesivas à sociedade, em prejuízo da efetiva a apuração das respectivas responsabilidades. Sob a égide de um suposto pragmatismo, nossos tribunais frequentemente recusaram-se a apreciar evidências de conduta faltosa ou a conceder às partes litigantes uma adequada produção de provas. De fato, uma vez que se aceita a premissa de que o consenso é um requisito permanente para a existência da sociedade e que, portanto, a conseqüência “lógica”, “natural” e "inevitável” da falta daquele é a dissolução desta, ou ao menos sua resolução limitadamente a um sócio, torna-se em grande medida desnecessário apurar qualquer outro dado fático além da própria existência de conflito ${ }^{29}$.

\footnotetext{
${ }^{28}$ STJ, Recurso Especial n ${ }^{\circ} 7.183$, DJU 16/10/91, Exmo. Monteiro de Barros. Acórdão já citado no Capítulo 1.

${ }^{29}$ STJ, Recurso Especial n 7.183, DJU 16/10/91, acórdão citado acima e no Capítulo 1, no qual o Exmo. Monteiro de Barros afirma que: "Também irrelevante neste aspecto a asserção produzida pelo recorrente no sentido de a ré, ora recorrida, não se desincumbiu do ônus de evidenciar a justa causa para a despedida. Era suficiente, como referido, a desavença entre os sócios...”
} 
Nessa linha, por exemplo, o Tribunal de Justiça do Rio Grande Sul exarou decisão por meio da qual indeferiu a realização de perícia contábil, solicitada por um dos sócios para apurar possíveis irregularidades cometidas pelo sócio administrador, sob a justificativa de que tal procedimento seria irrelevante. Uma vez que a "comprovação da falta de compatibilidade para manter a relação social é o suficiente para acarretar a dissolução do vínculo societário”, a única perícia contábil a ser produzida seria aquela posterior, relativa à apuração de haveres ${ }^{30}$. Apenas como exemplo adicional da postura geralmente adotada pelos julgadores brasileiros, pode-se mencionar igualmente um recente acórdão do Tribunal de Justiça do Rio de Janeiro, cuja ementa já afirma textualmente que seria "irrelevante investigar, perante ação de dissolução parcial de sociedade, quem efetivamente deu causa à ruptura da affectio societatis, mesmo porque basta à (sic) verificação da referida quebra para que se conceda o direito postulado" ${ }^{31}$.

A teoria do rompimento da affectio societatis está de tal forma enraizada na doutrina e na jurisprudência brasileiras que se tornou um intermediário lógico, quase sempre redundante, em muitos julgados que tratam da exclusão de sócios. Assim, mesmo em casos em que os fatos alegados e demonstrados ao longo da lide seriam claramente suficientes para dar ensejo à expulsão, faz-se referência - como um verdadeiro apêndice argumentativo - à quebra da affectio societatis para justificar a aplicação do remédio da exclusão ${ }^{32}$.

Concordar com o argumento de que a existência da sociedade está sempre sujeita à permanência de um certo sentimento de "mútua estima”33 entre os sócios, significa afirmar que deve prevalecer entre estes últimos, a todo tempo, uma situação de idílio, sob pena de imediato término dos vínculos societários. Tal linha de pensamento soa totalmente inadequada. A sociedade empresária, principalmente na vigência do atual Código Civil, está dotada de diversos instrumentos criados exatamente para lidar com disputas e dirimi-

\footnotetext{
${ }^{30}$ TJRS, Agravo de Instrumento $\mathrm{n}^{\circ}$ 70010503183, de 17/02/05.

${ }^{31}$ TJRJ, Apelação 60.876/06, 09/01/07.

32 Em acórdão do Tribunal de Justiça de Minas Gerais, por exemplo, a despeito de terem sido inequivocamente demonstradas diversas irregularidades, como fraudes fiscais e desvio de fundos, a base para a exclusão do sócio infrator teria sido não o descumprimento de seu dever de lealdade, mas a ruptura da affectio societatis causada por tais abusos: "A existência de 'Caixa 2', de vendas feitas sem notas fiscais, depósitos não esclarecidos em nome de familiares e desvios de valores expressivos para a conta pessoal do sócio responsável por essas irregularidades, que têm conseqüências fiscais e econômicas, justifica a quebra da 'affectio societatis', que leva à dissolução parcial da sociedade, com retirada do sócio culpado.” TJMG, Exma. Des. Vanessa Verdolim Hudson Andrade, Apelação Cível no 358.239-4, 07/05/2002.

33 "A colaboração se baseia na mútua estima de seus membros, que se consideram todos iguais, e é o que se chama 'affectio societatis'." (grifo no original) in R. REQUIÃO, A Preservação da Sociedade Comercial pela Exclusão de Sócio, p. 38-39.
} 
las, ao mesmo tempo em que, na medida do possível, evita-se prejuízo para a consecução dos objetivos sociais. O próprio regime de deliberação não é mais do que um sistema voltado ao convívio com a discórdia e resolução ordenada desta última. Não é por outro motivo que existem regras para a convocação e condução de conclaves e critérios para superação de impasses. Ou seja, a sociedade empresária contemporânea não apenas não é estranha à existência de conflitos entre os sócios, nem se demonstra com incompatível com eles, como praticamente toda a sua disciplina tem como pressuposto justamente a possibilidade constante de que o consenso venha a faltar.

Convém recordar que, precisamente na França, onde a doutrina moderna da affectio societatis foi desenvolvida e consolidada, formou-se e ainda prevalece uma visão extremamente conservadora a respeito da possibilidade de exclusão de sócios ${ }^{34}$, diametralmente contrária à forma de aplicação do instituto no Brasil. Conforme registrou Bernard Caillaud, mesmo na hipótese de pedido de dissolução antecipada da sociedade por prazo determinado, nos termos do artigo 1.871 do Code Civil, a jurisprudência francesa demonstra cautela em relação a alegações baseadas na existência de graves conflitos entre os sócios, recusando-se a decretar a dissolução sempre que não se demonstre que tal desinteligência seja capaz de levar a sociedade à efetiva paralisia ${ }^{35}$.

Em resposta às distorções e abusos que o recurso à doutrina do rompimento da affectio societatis ensejou no Brasil, já há muito a nossa melhor doutrina aponta para a necessidade de prudência na aplicação de tal preceito. Com efeito, Soarias de Faria já havia salientado, em 1926, que a simples divergência entre os sócios não poderia resultar na exclusão de um deles, mas que apenas o conflito grave a ponto de inviabilizar a continuidade das atividades sociais poderia acarretar a solução extrema da expulsão ${ }^{36}$. Esta posição tem o grande mérito de reorientar a discussão no sentido da preservação da empresa, uma vez que a mera ausência superveniente de consenso é substituída pelo prejuízo à realização do objeto social como critério relevante para a aplicação do remédio extremo da exclusão.

\footnotetext{
${ }^{34}$ Vide Capítulo 1, a esse respeito.

35 “N'oublions pas, en effet, que les tribunaux se refusent en général à prononcer la dissolution des sociétés si les justes motifs invoqués, notamment la mésintelligence grave entre associés, ne font pas ressortir que le fonctionnement de la societé est paralysé.” in B. CAILLAUD, L'Exclusion d'un Associé dans les Sociétés, p. 248.

36 "É preciso, porém, que a desintelligencia chegue ao ponto de destruir a confiança entre os socios, tornando-se seria e permanente.” in S. FARIA, Da Exclusão de Socios nas Sociedades de Responsabilidade Illimitata, p. 30.
} 
Ocorre que mesmo a doutrina que julga necessária a presença de conflito grave, capaz de causar dano à empresa, mantém aberta a possibilidade de recurso arbitrário ao instituto da exclusão. Efetivamente, ao prevalecer tal critério, aos sócios majoritários que desejarem expulsar um consócio sem justa causa bastará insistentemente instigar conflitos e esperar que eventualmente sejam recompensados pela exacerbação das disputas que eles próprios fomentaram.

Além disso, trata-se de uma formulação de difícil aplicação prática, em conseqüência da forte carga de subjetividade que a noção de affectio societatis inevitavelmente encerra ${ }^{37}$. A este respeito, serve de ilustração acórdão do Tribunal de Justiça de São Paulo, no qual a turma julgadora reverteu decisão da juíza a quo, a qual entendera que os conflitos existentes entre os sócios não comprometiam a condução da atividade empresarial e, portanto, não justificavam a exclusão então pleiteada. O argumento usado para determinar a aplicação da exclusão foi o de que não caberia à magistrada de primeira instância avaliar se os conflitos existentes entre os sócios, de cuja existência - como de praxe - os próprios autos seriam testemunhas, haviam ou não afetado a possibilidade de desenvolvimento conjunto da atividade empresarial ${ }^{38}$.

Com efeito, há espaço para argumentar que, mesmo em sua versão aprimorada e reformulada, a doutrina da ruptura da affectio societatis, permanece conceitualmente irreconciliável com a noção de que a justa causa é um requisito essencial para a admissão da exclusão, tal como discutida no tópico anterior. Em primeiro lugar, tal visão é estruturalmente incompatível com a noção prevalentemente aceita de que a sociedade é um contrato plurilateral. Efetivamente, não são as vicissitudes verificadas nos vínculos bilaterais entre os próprios sócios que podem ensejar a aplicação do remédio da exclusão, mas sim aquelas presentes na relação entre o sócio e a sociedade.

\footnotetext{
37 “A simples alegação de perda da affectio societatis não me parece nem é, de modo algum, razão suficiente para autorizar a exclusão - vale dizer, não se enquadra no conceito de justa causa para a exclusão, porquanto que advém exclusivamente de razões de foro íntimo.” in A. GONÇALVES NETO, Lições de Direito Societário, p. 297.

38 “A esse propósito, não há como amparar o argumento posto na sentença no sentido da subsistência da harmonia social. A uma, porque essa questão tem contornos subjetivos que não podem ser superados pela decisão judicial. A duas, porque a longa tramitação da ação denota clara e continuada desarmonia. A três, porque não basta estar o autor imbuído do interesse necessário à sobrevivência da sociedade, quando o mesmo interesse não é sustentado pelos sócios detentores do capital majoritário.” (sem grifo no original). Relator Exmo. Des. G. Pinheiro Franco, Apelação Cível nº 67.448-4/9, de 02/03/99.
} 
Ainda que se reconheça que, em sociedades marcadas pela atuação direta de sócios (pessoas naturais) na gestão, um ambiente de animosidade extremada possa dificultar ou mesmo impossibilitar o sucesso do negócio, não é possível concordar com a idéia de que a causa jurídica relevante para admissão da exclusão em tais hipóteses seja o rompimento da affectio societatis. Em tais situações, a discórdia entre os sócios é meramente a possível causa remota - para não dizer psicológica - de violações dos deveres dos sócios, as quais estas sim - podem ensejar a exclusão.

Não sendo possível identificar uma violação concreta, culposa ou não, dos deveres do sócio perante a sociedade, nas mais diversas modalidades que esta possa assumir (não colaboração, abuso de direito de voto ou de fiscalização, deslealdade etc.), a solução extrema da exclusão não poderá ser aplicável, ainda que reine entre os sócios clima de absoluta hostilidade.

Brunello Acquas cita, por exemplo, o caso em que o tribunal de Cagliari (de 18 de abril de 2005) indeferiu pedido de exclusão de sócio que havia agredido fisicamente sua filha e consócia, por entender que tal fato, a despeito de sua inequívoca gravidade, não representava obstáculo à continuidade das atividades sociais. Para o referido autor - num raríssimo exemplo de referência ao conceito de affectio societatis por parte da doutrina italiana - a decisão seria equivocada, posto que caberia à autoridade judicial afastar o socio rixosus que destruíra o necessário consenso entre os demais sócios ${ }^{39}$.

No caso descrito, tratando-se de sociedade em nome coletivo dotada de gestão familiar com presumível intervenção direta dos sócios em suas atividades quotidianas -, pode-se concordar com as críticas do estudioso italiano ao julgado, mas não com os fundamentos por ele levantados. O sócio agressor deveria, de fato, ser excluído em tal hipótese, mas não em função da quebra da affectio societatis ou por agir como um socio rixosus e sim por ter prejudicado o desenvolvimento das atividades da sociedade, em clara violação do seu dever de colaboração. Ou seja, a exclusão seria aplicável ainda que a agressão fosse direcionada a um cliente, empregado ou fornecedor da sociedade, mas não seria automaticamente cabível na hipótese em que a vítima fosse um sócio meramente prestador de capital, completamente afastado da administração.

${ }^{39}$ B. ACQUAS, C. LECIS, L'Esclusione del Socio nelle Società di Persone, p. 56-57. 
Expulsar um dos sócios e promover uma parcial descapitalização da sociedade - como resultado do pagamento dos haveres do excluído - em função de uma questão estritamente privada e bilateral entre dois sócios, que não tenha um impacto direto sobre as atividades sociais, seria efetivamente contrário ao princípio da preservação da empresa. Por outro lado, exatamente porque as relações sócio-sócio e sócio-sociedade situam-se em planos diversos, é absolutamente evidente que, sendo ou não aplicável o remédio da exclusão, o sócio agressor ou infrator responderá sempre perante sua vítima pelos danos causados.

Em resumo, a grave desinteligência com os demais consócios pode motivar - e, normalmente, motiva - um sócio a não cumprir com suas obrigações perante a sociedade, mas não poderá, por si e em si, constituir a razão juridicamente relevante de sua expulsão do quadro de sócios. Nesse sentido, não se pode incluir o rompimento da affectio societatis no rol de causas que ensejam a aplicação do remédio da exclusão de sócios ${ }^{40}$. Como já alertava Dalmartello, tomar o rompimento do consenso como uma causa de exclusão implica, em última análise, admitir a exclusão ad nutum e, por conseqüência, renunciar ao requisito da justa causa ${ }^{41}$. Nestes termos, a doutrina do rompimento da affectio societatis representa a própria antítese do conceito de justa causa ${ }^{42}$.

A exclusão facultativa, sob pena de ser desvirtuada, deve estar sempre pautada pelo inadimplemento de uma obrigação societária, razão pela qual se impõe investigar, a seguir, quais são os principais deveres atribuíveis ao sócio de uma sociedade limitada.

\subsection{Violação do Dever de Colaboração}

O artigo 981 do Código Civil de 2002 define o contrato de sociedade como a assunção por duas mais pessoas da obrigação recíproca de contribuir, com bens ou (na verdade, “e/ou”) serviços, para o exercício de uma atividade comum. Contudo, a despeito de a noção de

${ }^{40}$ Em sua I Jornada de Direito Civil, o Conselho da Justiça Federal se reuniu para discutir a melhor interpertração e aplicação do Código Civil de 2002 e, como resultado, aprovou o Enunciado n ${ }^{\circ}$ 67, o qual afirma que: "Arts. 1.085, 1.030 e 1.033, III: A quebra do affectio societatis não é causa para a exclusão do sócio minoritário, mas apenas para dissolução (parcial) da sociedade”.

${ }^{41}$ A. DALMARTELLO, L'Esclusione dei Soci dalle Società Commerciali, p. 89.

${ }^{42}$ Nesse sentido, correta, mas infelizmente em sentido contrário à jurisprudência majoritária, a seguinte decisão do Tribunal de Justiça de Minas Gerais: “A simples ruptura da affectio societatis não é suficiente para determinar a exclusão de sócio de sociedade por cotas de responsabilidade limitada. Deve-se comprovar a existência de justa causa que possibilite a expulsão do sócio...”, TJMG, Exmo. Des. Nilo Lacerda, Apelação Cível no 1.0024.04.197839-6/001(1), 19/09/2007. 
colaboração estar presente na própria definição de sociedade, a única obrigação ativa expressamente atribuída pela lei ao sócio de uma sociedade limitada é a integralização da própria quota. Efetivamente, a exclusão do sócio remisso é uma das poucas causas de exclusão facultativa explicitamente consagradas pela lei.

Nesse sentido, o presente tópico se dedica primeiramente a analisar a exclusão do sócio remisso para, em seguida, discutir as condições excepcionais em que um quotista pode ser afastado compulsoriamente da sociedade em razão da violação de uma obrigação de colaboração acessória, isto é, um outro dever que não a integralização da própria quota.

\subsubsection{Não Integralização da Quota Social}

O dever de integralizar a própria quota (ou quotas sociais) é, dentre as obrigações atribuíveis ao sócio, aquela enunciada de forma mais eloqüente pela legislação. Trata-se, sem dúvida, de um dos deveres mais fundamentais do sócio em todos os tipos societários. É uma questão que extrapola os confins da sociedade, uma vez que atinge diretamente sua integridade patrimonial e, por conseguinte, os interesses de seus credores e terceiros de boa-fé. Não é por acaso que a não integralização da participação societária representa uma das únicas hipóteses, seja no Brasil (artigos 106 e 107 da Lei nº 6.404/76), seja no Direito Comparado, em que se admite expressamente a exclusão do acionista nas sociedades por ações, ainda que em algumas jurisdições se utilize a expressão “decadência das ações”43.

O Código Comercial de 1850 já tratava da exclusão do sócio que não integralizasse a sua participação em seu artigo 289, ao permitir a rescisão da sociedade “a respeito do sócio remisso”. Tal dispositivo, por si só, já representava uma importante inversão da linha clássica e individualista que orientava a antiga norma, a qual, na maioria dos casos, impunha a dissolução strictu sensu da sociedade. Mesmo o lacônico Decreto 3.708/19, reservou o artigo $7^{\circ}$ para reiterar as disposições do artigo 289, usando explicitamente a expressão “exclusão”, e para ampliar as opções disponíveis à sociedade e aos sócios adimplentes, assegurando a possibilidade de transferir as quotas do remisso a terceiros.

Na sociedade limitada, em particular, tal questão é efetivamente de extrema importância para os próprios sócios -, e não apenas para a sociedade ou para os credores sociais - posto

${ }^{43}$ A. DALMARTELLO, L'Esclusione dei Soci dalle Società Commerciali, p. 106. 
que respondem solidariamente pelo capital social não integralizado e, portanto, enfrentam o permanente risco de arcarem com as conseqüências do inadimplemento do quotista remisso.

Coerentemente, o Código Civil de 2002 dedicou especial atenção à hipótese de inadimplemento de tal obrigação. O artigo 1.004 - sempre aplicável à sociedade limitada, por força da remissão expressa contida no artigo 1.058 - prevê que, em caso de mora na integralização da quota, o sócio remisso deve ser interpelado por escrito. Se o respectivo inadimplemento não for sanado dentro de um prazo de trinta dias a contar da entrega da respectiva notificação, os demais sócios podem escolher livremente entre: (i) a cobrança judicial (ou arbitral) da prestação devida, (ii) a redução da quota do remisso ao montante eventualmente já realizado ou (iii) sua exclusão da sociedade.

Nas duas últimas hipóteses, tratando-se de outras sociedades que não a limitada, as soluções preconizadas pelo artigo 1.004 implicam a redução do capital social, salvo se os demais sócios cobrirem a lacuna de fundos criada pelo inadimplemento do remisso, suprindo a sua quota. Na sociedade limitada, todavia, os sócios adimplentes têm uma opção adicional à sua disposição. Como já previa o Decreto 3.708/19 para a antiga sociedade por quotas, o artigo 1.058 do Código Civil de 2002 determina que, na sociedade limitada, a exclusão do remisso poder ser atrelada à transferência de suas quotas a terceiro, em substituição à redução do capital social.

Em tal situação, caso o remisso já tenha integralizado parcialmente a sua participação, terá direito a um reembolso, mas à sociedade caberá reter os valores relativos a juros de mora, despesas e multas contratuais. Contrariamente à sociedade simples, exemplo típico de sociedade de pessoas, o caráter híbrido da sociedade limitada enseja a admissão de terceiros como sócios. Trata-se de uma solução muito mais adequada para a própria sociedade - que não sofre dano em sua integridade patrimonial -, para os credores sociais - que não vêem diminuição no patrimônio que garante suas dívidas - e para os sócios remanescentes, cujo empreendimento é resguardado e não têm de lidar com uma participação não integralizada, pela qual poderiam responder solidariamente.

No que tange a utilização da exclusão de sócio como instrumento de tutela da integridade do capital social, verifica-se um peculiar silêncio do Código Civil de 2002 em relação às 
hipóteses de evicção do bem conferido ao capital da sociedade ou de insolvência do devedor de crédito que tenha o mesmo destino. Tais situações produzem efeitos análogos aos da não integralização da participação, mas o Código de Civil de 2002 não previu em tais hipóteses a possibilidade de exclusão do sócio, prevendo simplesmente no artigo 1.005 a responsabilidade do sócio que respectivamente transferiu o domínio, ou o crédito, à sociedade. Caso a sociedade limitada tenha como regime supletivo a disciplina das sociedades anônimas, nos termos do parágrafo único do artigo 1.053 do Código Civil de 2002, aplica-se a tais hipóteses o artigo 10 da Lei Federal n 6.404/76, mas o conteúdo de tal dispositivo é muito similar à disciplina da matéria nas sociedades simples, remetendo a integralização deficiente às normas que tratam da evicção.

Na ausência de disposição legal expressa, cumpre indagar se em tais casos de descapitalização superveniente da sociedade pode-se admitir a exclusão do sócio responsável conferência de bens ou créditos viciada. Para tanto, seria necessário qualificar a evicção do bem ou a insolvência do crédito como uma “falta grave” ou "ato de inegável gravidade”. Em função dos danos causados à sociedade, potencialmente até mais graves do que os derivantes da não integralização das quotas, seria possível, em princípio, responder afirmativamente.

Por outro lado, não se pode menosprezar a importância do ato de avaliação e aceitação da conferência de bens ao capital da sociedade por parte dos demais sócios, nos termos do parágrafo $1^{\circ}$, artigo 1.055, do Código Civil de 2002. Ao concordarem com a integralização de quota com bens ou créditos, presume-se que os consócios analisem e estimem o bem pelo que é e pelo que vale, no momento da própria conferência, tanto que respondem solidariamente pelo valor respectivamente atribuído, durante um prazo de cinco anos.

O risco inerente à titularidade sobre a coisa ou solvência do crédito, que antes era suportado exclusivamente pelo sócio conferente, passa a pertencer à sociedade. Contudo, antes de tal transferência, tal risco deve idealmente ser refletido no valor de subscrição. Nesses termos, seria injusto, apenas como exemplo, excluir um sócio cujo crédito conferido ao capital se revele insolvente, mas tenha sido integralizado com valor inferior ao nominal, ou seja, com deságio proporcional ao risco estimado de inadimplemento do devedor final. 


\subsubsection{Incapacidade Superveniente e não Prestação de Serviço}

O artigo 974 do Código Civil de 2002 estabelece claramente a possibilidade de um incapaz, através de representante ou assistente, dar continuidade a uma empresa individual exercida por reste último anteriormente ao estado de incapacidade ou recebida em herança. Esse fato demonstra que não existe em nosso ordenamento uma incompatibilidade elementar ou estrutural entre o estado de incapacidade e a participação em empreendimento econômico, empresarial ou não.

Se a incapacidade pode ser tolerada em relação à empresa individual, com maior razão pode ser admitida no contexto de uma sociedade, no qual o peso das decisões e da contribuição pessoal do incapaz (na pessoa de seus representantes ou com auxílio de seus assistentes) pode ser compartilhado com os demais sócios.

Mesmo o longo debate doutrinário que cercou a possibilidade de admissão de sócio menor e impúbere na antiga sociedade por quotas tinha como ponto central o risco de dano ao patrimônio do incapaz, decorrente da responsabilidade solidária dos quotistas em relação ao capital social não integralizado, e não a sua intrínseca impossibilidade de participar da gerência e contribuir pessoalmente com o empreendimento ${ }^{44}$.

Nesse sentido, mesmo no âmbito das sociedades simples, a regra contida no artigo 1.030 do Código Civil de 2002, segundo a qual a incapacidade representa uma das causas de exclusão, deve ser interpretada com extrema cautela. Em primeiro lugar, não se trata de comando cogente do legislador ou hipótese de exclusão de pleno direito, não cabendo qualquer automatismo na aplicação de tal preceito. A lei é clara ao indicar que a incapacidade pode (mas não necessariamente deve) constituir causa de exclusão, mas apenas caso seja essa a vontade dos demais sócios.

De fato, é perfeitamente plausível que os consócios entendam que a apuração dos haveres do incapaz resultante de sua exclusão cause um dano maior à sociedade do que a permanência de um sócio inapto a oferecer sua contribuição pessoal e direta às atividades

44 J. LUCENA, Das Sociedades Limitadas, p. 232. E. TEIXEIRA, Das Sociedades por Quotas de Responsabilidade Limitada, p. 47. 
sociais. A incapacidade é apenas estruturalmente incompatível com o exercício de cargo de administrador, mas não com a simples propriedade de participação social ${ }^{45}$.

De qualquer modo, mesmo que os demais consócios se demonstrem favoráveis à exclusão do incapaz, é necessário um mínimo de razoabilidade na admissão de sua expulsão. É necessário que exista proporcionalidade entre a contribuição pessoal esperada, expressa ou implicitamente, do sócio em questão e o impacto da sua incapacidade superveniente sobre sua possibilidade de prestá-la.

Tratando-se, por exemplo, de enfermidade que impeça o sócio de, apenas transitoriamente, exprimir sua vontade, nos termos do inciso III do artigo $3^{\circ}$ do Código Civil de 2002, mas cujo prognóstico médico (tecnicamente qualificado) seja de melhoria em curto prazo, não haveria razão para se admitir a exclusão de sócio. O mesmo pode-se dizer da situação de um sócio que seja reconhecido como pródigo, conforme o artigo $4^{\circ}$ do mesmo diploma, mas não participe de qualquer modo da gerência contábil ou financeira da sociedade e nem tenha poderes para, isoladamente, assumir obrigações em nome desta.

Na sociedade limitada, em particular, não se poder presumir - no silêncio do contrato social - que o sócio tenha qualquer outra obrigação ativa, concreta e específica que não a integralização de sua participação no capital social. Não havendo uma obrigação específica de colaboração pessoal, não se pode afirmar que a incapacidade superveniente seja qualquer forma incompatível com a manutenção da qualidade de quotista, enquanto mero prestador de capital.

Esse fato levou Modesto Carvalhosa a afirmar que, em relação à sociedade limitada, mais do que ser compatível com a conservação da qualidade de sócio, a incapacidade superveniente sequer poderia representar uma hipótese de exclusão. Para o prestigiado autor, com efeito, a parte final do artigo 1.030 do Código Civil de 2002 simplesmente não seria aplicável às sociedades limitadas - a despeito da ressalva expressa contida no artigo

45 “No tocante à sociedade, seus sócios podem ser incapazes, desde que não assumam a administração.” in H. VERÇOSA, Curso de Direito Comercial, vol. 2, p. 105. 
1.085 - em função da natureza mista, com elementos de sociedades de pessoas e de sociedades de capitais, de tal tipo societário ${ }^{46}$.

Dadas as características gerais da sociedade limitada, sobretudo quando o regime supletivo adotado seja o das sociedades anônimas, é efetivamente razoável afirmar que, no silêncio do contrato social e como regra geral, a incapacidade superveniente de um sócio não represente uma justa causa para a sua exclusão.

Por outro lado, excluir de antemão e em todos os casos a possibilidade de que a incapacidade superveniente seja, expressa ou implicitamente, eleita pelos sócios como uma hipótese justificadora da exclusão soa como uma injustificável limitação da liberdade contratual.

Um dos mais aventados méritos da nova sociedade limitada deveria ser precisamente a liberdade concedida aos sócios de moldar o seu regime jurídico à imagem das sociedades de pessoas ou, alternativamente, aproximá-lo da disciplina das sociedades anônimas, conforme as necessidades de cada situação concreta ${ }^{47}$.

O parágrafo $2^{\circ}$ do artigo 1.055 do Código Civil de 2002 veda a integralização da quota com serviços, mas o faz simplesmente para assegurar a solidez do capital social, de forma a proteger os credores da sociedade. Não parece adequado afirmar que tal dispositivo encerre uma proibição geral de atribuição aos sócios da obrigação de contribuir, direta e ativamente, com as atividades da sociedade, até porque seria incongruente com a flexibilidade que se quis conferir à sociedade limitada ${ }^{48}$.

Nestes termos, não parece haver razão para se afirmar que os sócios de uma sociedade limitada, cujo regime supletivo seja o da sociedade simples, não possam estabelecer expressamente em seu contrato social que a contribuição pessoal e ativa, ou mesmo o

\footnotetext{
46 “....não poderá haver na limitada exclusão por incapacidade permanente ou temporária (arts. $3^{\circ}$, II e III, e $4^{\circ}$, II), por se tratar de sociedade mista de capital e de pessoas, em que não prevalece o caráter presumidamente pessoal das sociedades simples." in M. CARVALHOSA, Comentários ao Código Civil Parte Especial do Direito de Empresa, p. 311

${ }^{47}$ M. CARVAlHOSA, Comentários ao Código Civil - Parte Especial do Direito de Empresa, p. 40.

${ }^{48}$ Em sentido contrário: “...o $§ 2^{\circ}$ do art. 1.055 proíbe expressamente nas limitadas a contribuição de sócios consistente na prestação de serviços. Neste sentido, a sociedade que alegar falta grave na prestação de serviços para justificar a exclusão de sócios estará, na verdade, confessando sua natureza de sociedade, segundo o disposto no art. 997, V, do NCC.” in H. VERÇOSA, Curso de Direito Comercial, vol. 2, p. 531.
} 
exercício permanente do cargo de administrador, por parte de determinado sócio sejam relevantes e necessários. Em tal hipótese, caso o sócio, padecesse de moléstia grave e irreversível que impossibilite sua prestação, a exclusão seria um remédio adequado.

Em diversos setores de atividade, a reputação, a habilitação profissional e as habilidades pessoais do sócio podem exercer uma função essencial ao sucesso do empreendimento. Este é um fato verificado tipicamente em sociedades que, nos termos do parágrafo único do artigo 982 Código Civil de 2002, exercem atividades não-empresárias, mas que podem, não obstante, ser constituídas sob a forma de sociedade limitada (por força do artigo 983), tais como agências de publicidade, escritórios de arquitetura e decoração e clínicas médicas ou odontológicas ${ }^{49}$. Entretanto, mesmo em ramos de atividade claramente empresariais, como por exemplo, academias de ginástica e artes marciais, salões de beleza, restaurantes e confecções de luxo, tais características também podem estar presentes.

Além disso, é prática comum que a maioria social financie a integralização da quota de um indivíduo com notórios conhecimentos técnicos ou especial habilidade de gestão, que é admitido na sociedade como uma espécie de “sócio de indústria” (de fato, e não de direito). Não é raro, tampouco, que um indivíduo seja aceito como quotista exclusivamente por possuir habilitação profissional exigida pela lei - médico, farmacêutico, engenheiro, agrônomo -, tornando-se formalmente responsável técnico por parte das atividades da sociedade.

Não se pode deixar de considerar, outrossim, o fato de que a forma de sociedade limitada é adotada também por diversas pequenas e micro empresas, nas quais os sócios participam diretamente das atividades quotidianas. Frequentemente, tais sociedades sequer possuem empregados ou colaboradores não-sócios. No âmbito de tais empreendimentos, a simples capacidade de trabalho de cada sócio, independentemente de qualquer talento particular ou renome, pode exercer um papel relevante para a viabilidade do negócio.

Em todos os casos mencionados, tanto a própria atribuição da qualidade de quotista como o equilíbrio econômico estabelecido em relação às prestações exigidas de seus consócios, estão fortemente lastreados na contribuição individual e pessoal que se espera do sócio.

${ }^{49}$ H. VERÇOSA, Curso de Direito Comercial, vol. 2, p. 344-345. 
Parece, portanto, justo e razoável que a sociedade possa excluí-lo caso se verifique uma situação intrinsecamente incompatível com a continuidade de tal colaboração ${ }^{50}$.

Há quem argumente que a exclusão do incapaz seria inclusive inconstitucional, uma vez que a maior parte das hipóteses de incapacidade superveniente não é o resultado de ato voluntário do excluendo ${ }^{51}$. A este respeito, convém recordar que a exclusão facultativa não representa pena ou sanção, mas mero instrumento de reação ao inadimplemento contratual, uma expressão particular da rescisão do contrato por inadimplemento, que prescinde de qualquer elemento de dolo ou culpa, como já discutido no início deste capítulo.

A não integralização do capital social, por exemplo, também pode ser o resultado de hipóteses de caso fortuito ou força maior, absolutamente fora do controle do sócio remisso. O sócio pode tornar-se vítima de fraude, vendo-se privado dos fundos necessários à integralização, ou o bem que almejava conferir ao capital social da sociedade pode perecer em razão de catástrofe natural. A sua exclusão, não obstante, é perfeitamente cabível em tais situações e não se cogita de inconstitucionalidade.

O mesmo raciocínio aplicado especificamente à possibilidade de exclusão por incapacidade superveniente pode ser empregado para explicar também a expulsão do sócio pelo inadimplemento de obrigação de realizar atividade em favor da sociedade limitada, assumida no contrato social. Pode-se, inclusive, afirmar que a incapacidade superveniente é simplesmente uma espécie desta última hipótese de inadimplemento. Afinal, ambas as situações compartilham o mesmo fundamento: o descumprimento do dever geral de colaboração, em relação a uma obrigação distinta da integralização da própria quota.

A principal diferença entre ambas as hipóteses é que a incapacidade superveniente é expressamente mencionada pelo artigo 1.030, caput, enquanto a falha em colaborar com a sociedade por outras razões deve ser enquadrada como "falta grave" ou "ato de inegável gravidade” para que possa amparar a exclusão de um sócio. De qualquer modo, a exclusão

\footnotetext{
${ }^{50}$ Em favor de tal entendimento no âmbito da sociedade limitada com características personalistas, Herbert Wiedmann assinalou que: "In einer personalistisch ausgerichteten, auf die Mitarbeit aller Gesellschafter angelegten $\mathrm{GmbH}$ hat die Gesellschaft ein berechtigtes Interesse daran, daß alle Gesellschafter mitarbeiten. Das Ende der Mitarbeit ist daher ein sachlicher Grund, einen Gesellschafter am künftigen Erfolg des Unternehmens nicht mehr zu beteiligen." (grifo no original) H. WIEDEMANN, Gesellschaftsrecht Rechtsfälle in Frage und Antwort, p. 495.

${ }^{51}$ O. ASSIS, A Sociedade Contratual e o Sócio Incapaz (Incapacidade Superveniente) no Código Civil de 2002: uma evidente Inconstitucionalidade, p. 2-3.
} 
apenas será possível se a prestação (não-monetária) devida pelo quotista à sociedade for expressamente estipulada no contrato social, porque - como já dito à exaustão - não é intrínseco à sociedade limitada nenhum um outro dever de colaboração que não a integralização do capital social.

Em resumo, pode-se afirmar que, em princípio e como regra geral, não é cabível a exclusão do sócio por incapacidade superveniente nas sociedades limitadas, uma vez que: (i) tal tipo societário admite a figura do sócio mero prestador de capital, (ii) no silêncio do contrato social, não se pode presumir uma obrigação concreta de colaboração ativa do quotista para além da integralização de sua quota e (iii) verifica-se, outrossim, uma tendência histórica de aproximação do regime da híbrida sociedade limitada às regras das sociedades de capitais.

Todavia, parece exagerado e incompatível com a flexibilidade que se espera da sociedade limitada - supostamente o grande trunfo deste tipo societário - impedir os sócios de prever no contrato social a essencialidade da contribuição (ativa, pessoal e individual) de um quotista, com a conseqüente admissão da possibilidade de sua exclusão em caso de inadimplemento de tal obrigação, seja por incapacidade, seja por outras causas.

\subsection{Violação do Dever de Lealdade}

O Código Civil de 2002 não enuncia expressamente um dever geral de lealdade imputável aos sócios, que seja aplicável tanto em suas relações com a própria sociedade, quanto em face de seus consócios. Tal princípio é, todavia, inequivocamente inerente ao próprio ordenamento jurídico e pode ser deduzido a partir de uma leitura sistemática do Código, tanto que é repetidamente colacionado pela doutrina e pela jurisprudência, no Brasil e em outras jurisdições ${ }^{52}$.

Em comentário às normas aplicáveis à sociedade limitada alemã, Barbara Grunewald defende a existência de um dever de lealdade (Treuepflicht) implícito, não previsto

\footnotetext{
${ }^{52}$ STJ, Recurso Especial n ${ }^{\circ}$ 388.423-SP, D.J.U. 04/08/2003. “...a sentença reconheceu que o requerido violou dever de lealdade pela prática de atos contrários ao interesses da sociedade empresária e da outra co-autora.” in TJSP, Rel. Exmo. Des. Ariovaldo Santini Teodoro, Apelação Cível no 287.198-4/1-00. "O sócio está obrigado a não violar deveres de conduta que possam causar prejuízos à sociedade, entre os quais se apontam os de lealdade, deveres que fazem parte do conteúdo das obrigações, como exigências gerais do sistema jurídico”, Supremo Tribunal de Justiça de Portugal, Acórdão de 15/02/2005, processo n. 4A4369.
} 
expressamente pela legislação, mas ainda assim imponível a cada um dos quotistas e que se desdobraria em dois sentidos: (i) em confronto à própria sociedade e (ii) relativamente aos demais sócios. O conteúdo preciso de tal dever não seria determinável de antemão, derivando da estrutura concreta de organização de cada sociedade ${ }^{53}$. Entre os doutrinadores nacionais, pode-se citar o Professor Haroldo Verçosa como um dos defensores da existência de um dever de lealdade do sócio para com a sociedade ${ }^{54}$.

Pode-se, inclusive, argumentar que o dever de lealdade do sócio é uma simples manifestação societária da regra geral da boa-fé objetiva. Enquanto contrato, a sociedade também estaria sujeita ao disposto no artigo 422 do Código Civil de 2002, de modo que os sócios estariam sujeitos a tal “cláusula implícita”, que é válida, eficaz e vinculante, mesmo quando não seja expressamente reiterada pelo contrato social. De fato, descrente da existência de um dever geral de colaboração que impusesse ao sócio outras obrigações ativas além da integralização da própria quota, Giuseppe Bollino vislumbrou no princípio geral da boa-fé (Código Civil Italiano de 1942, artigo 1.375) a melhor explicação para aplicação do remédio da exclusão ${ }^{55}$.

Como bem recorda a Professora Judith Martins Costa, o princípio da boa-fé objetiva contratual - já presente em nosso ordenamento, como decorrência lógica dos princípios gerais de justiça, muito antes de ser expressamente mencionado pela lei - não representa um simples e genérico reclamo à ética ${ }^{56}$. Ao contrário, consiste em mecanismo com múltiplas repercussões práticas e concretas. A aplicação de tal preceito tem como desdobramentos diretos (i) uma mudança de perspectiva na interpretação dos contratos, (ii) a limitação do exercício de direitos subjetivos, com a tutela das situações de abuso e, principalmente, (iii) a atribuição às partes contratantes de determinados deveres instrumentais ou acessórios, mesmo quando não estipulados expressamente ${ }^{57}$. Entre os

\footnotetext{
53 “Wie beim Verein, der AG und bei den Personengesellschaften, so ergibt sich auch bei der GmbH aus dem Gesellschaftsvertrag - obwohl nie ausdrücklich erwähnt - eine Treuepflicht der Gesellschafter in doppelter Richtung: Zum einen gegenüber den anderen Gesellschaftern und zum anderen gegenüber der Gesellschaft. Die Intensität der Treuepflicht ist abhängig von der Struktur der jeweiligen Gesellschaft.” in B. GRUNEWALD, Gesellschaftsrecht, p. 321-322.

${ }^{54}$ Entre os doutrinadores nacionais, pode-se citar o Professor Haroldo Verçosa: “O dever de lealdade, [...], estabelece-se entre o sócio e a sociedade e transparecerá no momento em que o sócio, nesta qualidade, por exemplo, estiver exercendo o direito de voto.” in H. VERÇOSA, Curso de Direito Comercial, vol. 2, p. 126.

${ }^{55}$ G. BOLLINO, Le Cause di Esclusione del Socio nelle Società di Persone e nelle Cooperative, parte II, p. 544.

${ }_{56}^{5}$ J. MARTINS-COSTA, A Boa-Fé no Direito Privado, p. 436-437.

${ }^{57}$ J. MARTINS-COSTA, A Boa-Fé no Direito Privado, p. 427
} 
mencionados deveres acessórios, destacam-se os deveres de cuidado, informação e proteção.

O reconhecimento da existência de um dever de lealdade que seja parte integrante do feixe de obrigações atribuíveis ao quotista, como simples resultado de sua qualidade de sócio e independentemente de qualquer estipulação do contrato social, é extremamente importante para aplicação prática do instituto da exclusão facultativa de sócios. Em função da natureza contratual dessa modalidade de exclusão, a expulsão de um quotista deve estar, efetivamente, amparada na violação de uma obrigação do sócio para com a sociedade. Ocorre que nem sempre é fácil identificar obrigações acessórias claramente imputáveis ao quotista, em meio ao nebuloso hibridismo da sociedade limitada brasileira.

A introdução do dever de lealdade na equação da questão da exclusão facultativa de sócios tem o condão de tornar o remédio da expulsão perfeitamente aplicável, sem prejuízo à natureza contratual do instituto, a casos em que o sócio pratica atos ilícitos, contrários e lesivos aos interesses sociais, mas que não afrontam especificamente nenhuma obrigação, enunciada literal e expressamente pela lei ou pelo contrato social. Tal fato importa uma notável e oportuna ampliação do campo de incidência da exclusão, sobretudo quando se tem em conta a tênue base de deveres de colaboração impostos diretamente pela lei ao sócio. Sob essa ótica, atos como apropriação indébita, fraude, concorrência desleal, violação de sigilo, divulgação de informação caluniosa sobre a sociedade etc., passam a representar, além de infração à lei, a violação de uma obrigação de natureza contratual e societária, enquanto contrários à cláusula implícita de lealdade.

Contrariamente ao inadimplemento de obrigações que podem ser classificadas como expressões do dever de colaboração do sócio, a violação do dever de lealdade envolve sempre certo grau de culpa ou dolo. Isso não significa, contudo, que em tais casos a exclusão seja transmutada em pena ou procedimento disciplinar. A expulsão do sócio continua a representar, em tal hipótese, um mero remédio contratual, tanto que preserva seu caráter facultativo, estando sujeita à deliberação da maioria dos sócios e, portanto, à conveniência da sociedade; fato incompatível com uma penalidade, como já discutido anteriormente. Em tais situações, a presença de dolo ou de culpa é necessária simplesmente enquanto elemento caracterizador do próprio inadimplemento contratual, já que a obrigação violada não é outra que não o dever de lealdade. 
O primeiro e principal mérito da atribuição de um dever de lealdade ao sócio é tornar o remédio da exclusão aplicável a todas as hipóteses de atos ilícitos graves praticados pelo sócio contra a sociedade, ainda que não relacionadas diretamente à sua qualidade de quotista. Assim, em um exemplo extremo, caso o sócio se conluie com terceiros para saquear armazém com bens sabidamente pertencentes à sociedade, agirá em clara violação de seu dever de lealdade. Nesses termos, o dever de lealdade fornece a base necessária para a exclusão do sócio que viole gravemente deveres decorrentes da função de administrador da sociedade, como indicado a seguir.

O dever de lealdade permite também conciliar a natureza contratual da exclusão facultativa com a sua aplicação a hipóteses de abuso de direito por parte do sócio. Em tal âmbito, a principal forma de dano à sociedade resulta do abuso do direito de voto ${ }^{58}$. De fato, é comum que sócios minoritários votem sistematicamente contra deliberações úteis e necessárias à sociedade, propostas pela maioria social, não porque delas discordem, mas como mecanismo de pressão ou mesmo chantagem contra seus consócios. Como acenado no Capítulo 4, o estabelecimento de quoruns de deliberação qualificados pelo Código Civil de 2002 amplia em larga medida as possibilidades de adoção de estratégias obstrucionistas.

Pode-se vislumbrar, por outro lado, a possibilidade de abuso do direito à informação, nos casos em que o sócio repetidamente e de forma exagerada solicita acesso a documentos e dados da sociedade $^{59}$, não porque tenha dúvida sobre a correção da atuação da administração da sociedade, mas simplesmente porque tem a intenção de atravancar as atividades desta última, em violação ao disposto no artigo 187 do Código Civil de 2002.

Uma outra hipótese comum de caracterização de violação do dever de lealdade corresponde à concorrência desleal, em prejuízo da atividade social ${ }^{60}$. A concorrência desleal pode se verificar tanto pela prática de atos penalmente tipificados, nos termos do artigo 195, da Lei Federal n ${ }^{\circ}$ 9.279/96, como pela mera violação de acordos de não-

\footnotetext{
58 “O voto abusivo é aquele proferido contra o interesse da sociedade, vinculado à realização do objeto social, que é o campo de sua atividade.” in H. VERÇOSA, Curso de Direito Comercial, vol. 2, p. 126.

${ }^{59}$ B. GRUNEWALD, Gesellschaftsrecht, p. 364.

${ }^{60}$ Uma decisão do Tribunal de Justiça do Estado do Rio de Janeiro considerou uma violação de boa-fé objetiva a constituição, por parte de um dos sócios de sociedade limitada, de empreendimento concorrente, com nítido desvio de clientela, poucos meses antes do abandono do negócio desenvolvido em comum com outros sócios. TJRJ, Rel. Exmo. Des. Lindolpho Morais Marino, Apelação Cível nº 56.296, 24/01/2007.
} 
concorrência firmados com a sociedade. Além disso, mesmo que a lei não imponha uma vedação geral de concorrência ao quotista - recorda-se que o artigo 1.006 do Código Civil de 2002 é de aplicação restrita às sociedades simples -, pode-se entender que a conduta frontalmente destinada a desviar clientes da sociedade, por meio da atuação no mesmo ramo e mesma área geográfica, implica sempre violação da cláusula implícita de boa-fé objetiva $^{61}$.

61 “O dever de lealdade também é quebrado quando o sócio faz concorrência desleal à sociedade, exercendo a mesma atividade total ou parcialmente, atingindo a mesma clientela, que poderá ser desviada em favor da empresa do sócio deslealmente concorrente.” e ainda “...o sócio como tal, sempre estará obrigado a não concorrer com a sociedade, pois isto representa negar a realização de um fim comum.” in H. VERÇOSA, Curso de Direito Comercial, vol. 2, p. 127 e 128. 


\section{O PROCEDIMENTO DE EXCLUSÃO}

O presente capítulo tem como objeto a análise dos aspectos procedimentais da exclusão do sócio, em todas as formas previstas pelo Código Civil de 2002. A investigação parte da exclusão de pleno direito, evidentemente mais enxuta em termos de procedimento, para posteriormente tratar dos dois regimes de exclusão facultativa previstos pela lei.

\subsection{A Exclusão de Pleno Direito}

Representa quase uma contradição em termos discutir o "procedimento" aplicável a hipóteses de exclusão ipso iure, nas quais o desligamento do sócio da sociedade ocorre, em linha de princípio, como simples e automático resultado da verificação de determinado fato (liquidação das quotas ou falência do sócio), independentemente de quaisquer outras formalidades.

Todavia, o processamento da exclusão de pleno direito do sócio falido possui conseqüências práticas e nuances que merecem ser discutidas. A questão mais relevante sob esse ponto de vista é a competência e a forma para reconhecer formalmente a ocorrência da exclusão ipso iure. A esse respeito, merece atenção uma decisão administrativa proferida em novembro de 2006, por meio da qual Junta Comercial de São Paulo - JUCESP recusou o arquivamento de documento em se que pleiteava o reconhecimento da dissolução de pleno direito de uma sociedade limitada, nos termos do artigo 1.033, inciso $\mathrm{IV}^{1}$.

Em tal situação, alegava-se que a sociedade teria permanecido em situação de unipessoalidade por prazo superior a cento e oitenta dias justamente porque, meses antes, um dos únicos dois sócios teria sido declarado falido e, portanto, excluído de pleno direito da sociedade. Desse modo, excedido o período máximo de tolerância à unipessoalidade consignado pelo inciso IV do artigo 1.033, do Código Civil de 2002, a sociedade - uma vez mais, de pleno direito, ou seja, pela mera determinação da lei - estaria dissolvida.

O argumento utilizado pela JUCESP para recusar o registro do mencionado ato de deliberação baseou-se na idéia de que a expressão de "pleno direito”, conforme empregada

\footnotetext{
${ }^{1}$ JUCESP, Recurso ao Plenário n 990.391/06-1, de 16/11/2006.
} 
no parágrafo único do artigo 1.030, implica simplesmente a irrelevância da vontade das partes envolvidas, mas não tem o condão de tornar desnecessárias as formalidades legais tipicamente incidentes sobre o procedimento de registro ${ }^{2}$. Na opinião do referido órgão, o sócio remanescente deveria ter procedido à exclusão do consócio falido e apurado seus haveres e, apenas após o arquivamento do respectivo instrumento de exclusão, teria início a contagem do prazo previsto no inciso IV, do artigo 1.033 do Código Civil de $2002^{3}$.

A posição defendida na mencionada decisão administrativa padece do vício de condicionar a eficácia de determinado resultado, imposto ipso iure, à iniciativa da parte. Ao determinar que o prazo de contagem do período de unipessoalidade se inicia com o arquivamento de ato de exclusão do sócio, a decisão atribui inevitavelmente a este último uma eficácia constitutiva negativa do vínculo societário, o que não é compatível com uma hipótese de exclusão de pleno direito. É importante recordar, nesse sentido, que mesmo a sentença judicial que confirma a exclusão de pleno direito de um sócio não faz mais do que declarar algo que já ocorreu, por simples e direta determinação legal.

Em função de sua natureza ipso iure, a exclusão do sócio falido tem lugar com a simples ocorrência do fato previsto pela lei como necessário e suficiente para tal resultado: a declaração de falência. Assim, a data da exclusão em tal caso deve ser a mesma da sentença que declara o excluendo falido - seja ou não a exclusão expressamente determinada por esta última.

Não se pode afirmar que a recusa do registro em situação específica tão complexa ${ }^{4}$ tenha sido equivocada, mas certamente a justificativa adotada para tanto não parece adequada. Teria sido mais correto que a JUCESP declinasse da própria competência para decidir

\footnotetext{
2 “A expressão de pleno direito no dispositivo mencionado está a revelar que o resultado jurídico (exclusão da sociedade daquele sócio que faliu) independe da intenção da parte. Tal, entretanto, não quer dizer que o proceder prescinda de qualquer iniciativa, como parece pensar a sociedade. De pleno jure ou de pleno direito não traduz, não quer exprimir isento de formalidades ou de exigências legais. O sistema de registro não induz fatos, não descobre coisas, enfim, não é adivinho. Para que os atos ganhem existência legal e publicidade é preciso que sejam identificados e arquivados." (sem grifo no original) in JUCESP, Recurso ao Plenário ${ }^{\circ}$ 990.391/06-1, de 16/11/2006.

3 “...se a sociedade limitada se mantiver com o único sócio por mais de 180 dias, entrará em dissolução por força de lei - este fato não decorre da vontade do sócio remanescente, porém, haverá de ser por ele formalizado. No presente caso, consoante mostra a ficha cadastral anexada as fls 16/20 a sociedade não deu nenhum dos passos aludidos no item 12 supra: nada formalizou a respeito da falência de sua sócia e suas conseqüências.” in JUCESP, Recurso ao Plenário n 990.391/06-1, de 16/11/2006.

${ }^{4}$ Além da cumulação de duas hipóteses de incidência da lei com eficácia ipso iure, convém também notar que a falência do sócio fora declarada por tribunal estrangeiro.
} 
sobre a matéria em favor da autoridade judicial, simplesmente porque o deslinde da questão exigiria a análise de questões de fato e de direito, além da oitiva das partes interessadas.

Por outro lado, em situações de normalidade, ou seja, de simples falência do sócio, não parece efetivamente haver razão para negar à sociedade a possibilidade de constatar formalmente, por meio de simples deliberação dos consócios remanescentes, a ocorrência da exclusão de pleno direito do falido ${ }^{5}$. Se um dos motivos por trás de determinação da exclusão de pleno direito do sócio foi justamente isolar a sociedade da falência pessoal do quotista, é natural que a sociedade possa tomar as medidas necessárias para registrar tal afastamento, inclusive para que possa dar início à apuração de seus haveres. Não se tratará, frise-se, de decidir se o falido é ou não sócio, mas simplesmente reconhecer o fato de que não é mais quotista.

Em relação à declaração judicial da exclusão de pleno direito, esta pode ser requerida por qualquer parte que, em uma situação concreta, tenha interesse legítimo na questão, tais como a própria sociedade, o síndico da massa falida ou o credor pessoal do sócio.

Um outro aspecto delicado da exclusão de pleno direito do sócio concerne - como acenado acima - à declaração de falência pronunciada no exterior. A primeira questão nesse sentido, cujo aprofundamento extrapola os objetivos da presente análise, diz respeito a quais decisões judiciais podem ser recepcionadas em nosso ordenamento como “declaração de falência”, para os fins do parágrafo único do artigo 1.030 do Código Civil. De fato, é possível que sejam aplicados ao sócio - sobretudo quando se tratar de sociedade ou empresário estrangeiro - regimes especiais de reestruturação ou insolvência que não se enquadrem perfeitamente no conceito de estado falimentar, tal qual previsto pela lei brasileira.

De qualquer modo, cumpre indagar, em âmbito mais prosaico, se a sentença estrangeira que declara a falência de um sócio deve ou não ser homologada pela autoridade judicial brasileira. O artigo 483 do Código de Processo Civil condiciona, de fato, a eficácia de sentença estrangeira à sua prévia homologação. Nos termos da atual redação do artigo 150,

\footnotetext{
${ }^{5}$ M. CARVAlHOSA, Comentários ao Código Civil - Parte Especial do Direito de Empresa, p. 324.
} 
inciso I, alínea “i” da Constituição Federal, a competência para tal procedimento foi transferida do Supremo Tribunal Federal para o Superior Tribunal de Justiça.

Em uma primeira análise, tal formalidade parece indispensável para que a falência do sócio pronunciada no exterior possa ensejar a sua exclusão no Brasil. Contudo, como sabiamente observou o Desembargador Maia da Cunha, em decisão do Tribunal de Justiça de São Paulo (voto vencido), é extremamente importante ter em consideração que, o que se busca na hipótese em exame não é, em rigor, o cumprimento da sentença estrangeira, mas simplesmente a confirmação de um dado de fato ${ }^{6}$. É possível, se não mesmo provável, que a sentença proferida no exterior não determine a exclusão do sócio da sociedade brasileira. Não é de se excluir, com efeito, que esta última sequer seja mencionada pela decisão estrangeira.

Isso significa que não se trata de conferir, em território brasileiro, eficácia a um comando prolatado pela autoridade estrangeira, mas simplesmente de verificar a ocorrência de um fato ao qual a lei brasileira atribuiu determinadas conseqüências. É verdade que se busca permitir que a sentença estrangeira produza efeitos no Brasil, mas tais resultados, bem como a qualificação jurídica do fato (a declaração de falência) emanam, no caso em questão, do Direito brasileiro. A exclusão do sócio é puro resultado da aplicação da norma brasileira, cuja eficácia independe da concessão de mandamus às determinações de juiz estrangeiro.

Argumentando ad absurdum, pode-se imaginar a situação em que a sentença estrangeira declare o sócio falido, mas determine expressamente que ele não deve ser excluído da sociedade brasileira. A segunda parte da decisão colidiria frontalmente com a norma brasileira e seria, portanto, ineficaz. A primeira, ao contrário, configurando dado de fato previsto pela lei nacional, ensejaria a aplicação do parágrafo único do artigo 1.030 do Código Civil de 2002. Não existe, portanto, ofensa à soberania das normas nacionais e nem se justifica a exigência de um prévio controle de legalidade e aderência aos preceitos de ordem pública do ordenamento brasileiro por parte do Superior Tribunal de Justiça.

\footnotetext{
6 “Conquanto sutil, é diferente da eficácia para execução da sentença estrangeira no Brasil, a circunstância de ter, como motivação para a exclusão da sociedade, a confissão de estado falimentar na Argentina feita pelo autor ao pedir a própria falência. A prova documental existente a respeito não é para atos de execução daquele pedido falimentar, como arrecadação de bens e outros, mas exclusivamente para comprovar que, declarando-se o autor falido naquele País, dava motivo legal para a sua exclusão das empresas rés.” TJSP, Apelação Cível n 450.267-4/0, Exmo. Des. Maia da Cunha (voto vencido), 11/10/2007.
} 
É importante considerar, também, que a declaração de falência no exterior pode, conforme o caso, ser verificada por certidão emitida por órgão de registro comercial ou outra autoridade não judiciária. Se, em tal situação, pode-se considerar admissível a apresentação de documento com certificação consular, traduzido e registrado perante Registro de Títulos e Documentos (artigo 129, parágrafo $6^{\circ}$, Lei $n^{\circ}$ 6.015/73), não parece haver razão convincente para não dispensar o mesmo tratamento à sentença estrangeira.

\subsection{A Exclusão Facultativa}

Este tópico tem por objeto o exame dos dois procedimentos de exclusão facultativa estabelecidos pelo Código Civil de 2002. Inicia-se com a análise das questões mais amplas - titularidade do direito de exclusão e prazo para seu exercício - que são relevantes tanto para a exclusão judicial quanto para a expulsão deliberada diretamente pelos sócios. Em seguida, trata-se das peculiaridades de cada um dos regimes.

\subsubsection{Titularidade do Direito Material de Exclusão e Legitimidade Ativa}

Anteriormente à promulgação do Código Civil de 2002, a típica estrada para a consumação da exclusão de um sócio passava pela aplicação da doutrina da, assim chamada, “dissolução parcial”. Era necessário, em primeiro lugar, demonstrar que existia uma situação concreta que, sob as regras individualistas do Código Comercial de 1850, poderia conduzir à dissolução strictu sensu (dissolução total). Não se tratava de tarefa particularmente difícil, uma vez que mesmo a vontade unilateral do sócio ensejava a dissolução da sociedade, nos termos do artigo 335, parágrafo 5 do vetusto Código.

Em seguida, o tribunal reconhecia - a pedido do sócio interessado na continuidade da sociedade e em homenagem ao princípio da preservação da empresa -, a possibilidade de aplicar uma solução intermediária, menos drástica, “dissolvendo” a sociedade exclusivamente em relação ao excluendo ${ }^{7}$. Tratou-se de uma solução engenhosa, que permitiu minimizar os efeitos negativos de uma legislação antiquada e inadequada, mas que não era tecnicamente rigorosa e ensejou, portanto, diversas dificuldades.

\footnotetext{
${ }^{7}$ STF, Recurso Extraordinário n 50.659-RJ, Rel. Exmo. Min. Villas Bôas, D.J. 17/10/1962.
} 
Em particular, a doutrina da "dissolução parcial" compeliu os tribunais brasileiros a reconhecer que era o sócio e não a sociedade o detentor da legitimidade ativa para ação de exclusão. Afinal, a sociedade não poderia requerer a própria “dissolução”. Esse argumento demonstra que a inadequação da expressão “dissolução parcial” vai além de mera questão terminológica ou preciosismo de alguns doutrinadores, ensejando efetiva confusão interpretativa.

A fórmula “dissolução parcial” é empregada no Brasil para indicar a resolução do contrato de sociedade limitadamente a um sócio, com apuração de seus haveres e não representa, desse modo, uma espécie ou forma menor de dissolução ${ }^{8}$. A dissolução é, com efeito, instituto absolutamente diverso, que consiste na transmutação do objetivo social, do exercício de determinada atividade para a ultimação dos negócios sociais. A dissolução strictu sensu dá início à fase de liquidação, em preparação à eventual extinção da sociedade ${ }^{9}$.

A sociedade pode não ter legitimidade ativa para pleitear a própria dissolução, mas certamente cabe a ela propor ação judicial que tenha por escopo resolver um vínculo contratual entre o ente social e o sócio, em razão de grave inadimplemento deste último. Do mesmo modo que o sócio não pode, em nome próprio, cobrar de um consócio remisso a integralização da sua quota, não pode exercer uma prerrogativa contratual que pertence exclusivamente à sociedade.

É, portanto, natural que seja a sociedade a parte dotada de legitimidade ativa para propor a competente ação de exclusão. As obrigações cuja violação enseja a aplicação do instituto da exclusão têm natureza necessariamente societária; dizem respeito ao vínculo sóciosociedade, sob o manto do contrato plurilateral.

Em alguns casos, a permanente confusão entre os conceitos de dissolução e “dissolução parcial” foi agravada pelo uso amplo e corrente desta expressão para indicar especificamente a retirada unilateral do sócio da sociedade. A transposição de conceitos formulados no âmbito da "dissolução parcial strictu sensu" (ou seja, justamente a retirada unilateral ou demissão do sócio) para outras hipóteses de suposta “dissolução parcial”

\footnotetext{
${ }^{8}$ M. PENTEADO, Dissolução e Liquidação de Sociedades, p. 7.

${ }^{9}$ M. PENTEADO, Dissolução e Liquidação de Sociedades, p. 17-18.
} 
levou parte da doutrina a defender a inaceitável idéia de que a sociedade deve integrar o pólo passivo da ação de exclusão, sob o argumento de que cabe a esta última o eventual pagamento dos haveres do excluído ${ }^{10}$. Tal proposição equivale a afirmar que, na ação de resolução do contrato de locação por falta de pagamento, o proprietário deve figurar como réu.

Causa espécie que tal situação geral, muito pouco rigorosa sob um ponto de vista técnico, tenha persistido em nossos tribunais por tanto tempo, quando se toma em consideração o fato de que o Supremo Tribunal Federal, já havia decidido, em 1960, que a exclusão compete à sociedade e deve ser precedida de decisão da maioria social, mas não dos sócios individualmente ${ }^{11}$.

Com a promulgação do Código Civil de 2002, todavia, o direito à exclusão do sócio por grave inadimplemento foi expressamente consagrado pela lei e deixou de ser necessário percorrer o tortuoso caminho da dissolução parcial. Além disso, o próprio título da Seção $\mathrm{V}$, do capítulo dedicado às sociedades limitadas (Capítulo IV, do Título II do Livro da Empresa), refere-se expressamente à "resolução da sociedade em relação a sócios minoritários”, em claro sinal de que o legislador optou pela adoção de conceitos mais rigorosos. Nesse sentido, a vigência do Código Civil de 2002 poderia ter representado uma grande oportunidade para a definitiva superação das dúvidas e imprecisões existentes nessa matéria.

Ocorre, contudo, que a redação imprecisa do artigo 1.030 do Código Civil de 2002, que trata da exclusão judicial, não contribuiu para dissipar as concepções equivocadas vigentes anteriormente à promulgação da nova lei. Com efeito, o artigo em questão refere-se à possibilidade de exclusão “mediante iniciativa da maioria dos demais sócios”, o que levou parte da doutrina a atribuir a legitimidade ativa na ação de exclusão aos sócios conjuntamente detentores da maioria do capital social.

\footnotetext{
10 “Já se demonstrou que a ação tendente a afastar o sócio da sociedade somente poderá ser contra este promovida, desde que se mostre inviável a deliberação acerca da expulsão. No entanto, promovida a ação de exclusão pela maioria representativa de mais da metade do capital social, tal como faculta o art. 1.085 do Código Civil, devem ser guindados ao pólo passivo da ação o sócio excluído, a sociedade e os demais sócios.” (sem grifo no original) in P. CORRÊA, Dissolução Parcial, Retirada e Exclusão do Sócio, p. 120. STJ, Recurso Especial n 735.207-BA, Rel. Exmo. Min. Carlos Alberto Menezes Direito, D.J.U. 07/08/2006. STJ, Recurso Especial n ${ }^{\circ}$ 813.430-SC, Rel. Exmo. Min. Massami Uyeda, D.J.U. 20/08/2007.

${ }^{11}$ STF, Recurso Extraordinário no 43.681 (Estado da Guanabara), Rel. Exmo. Min. Lafayette de Andrada, de 08/07/1960, publicado em 25/01/1961.
} 
Tais sócios não podem, todavia, pleitear em juízo, em nome próprio um direito que é da sociedade. O único modo de ler a referida passagem do artigo 1.030 é, portanto, como uma referência imprópria e atécnica à necessidade de deliberação prévia dos sócios, como requisito à propositura da ação de exclusão ${ }^{12}$. A exclusão de um sócio é uma decisão crítica, que sempre comporta um relevante impacto sobre a sociedade e seu patrimônio. É natural, portanto, que o legislador tenha exigido - analogamente ao que se verifica em hipóteses como a aprovação de projeto de fusão - que os sócios fossem previamente ouvidos antes que se propusesse uma medida judicial ${ }^{13}$.

Contudo, tal formalidade representa mera parte do procedimento de formação da vontade social, tal como se verifica na assembléia de exclusão extrajudicial prevista pelo artigo 1.085, e não uma forma de delimitação da legitimidade ativa para a ação de exclusão. A exclusão facultativa de um sócio, tanto pela via judicial quanto extrajudicialmente, é sempre um ato da sociedade; a intervenção dos sócios é necessária simplesmente porque essencial à formação da vontade desta última.

Na exclusão judicial, após a aprovação da proposta de exclusão pela maioria dos sócios, a competente ação judicial deverá ser proposta pela própria sociedade, representada por seus administradores - sócios ou não e, de qualquer modo, titulares exclusivos do uso da firma social, conforme o artigo 1.064 do Código Civil de 2002 - que, por sua vez, nomearão os advogados do ente social.

De fato, quando a lei menciona a "maioria social” inevitavelmente se refere a um órgão de deliberação da sociedade, e não a quotistas individualmente. A “maioria dos sócios” não se forma pela mera adesão de um grupo de sócios detentores de certa participação em torno de uma determinada idéia, mas deve ser apurada em sede própria, com a satisfação dos

\footnotetext{
12 "A iniciativa de excluir um sócio deve ser necessariamente tomada pela sociedade a partir de deliberação em assembléia de sócios, descabida qualquer pretensão individual a respeito deste tema, conforme se depreende da leitura dos arts. 1.030 e 1.085 do NCC. A referência feita à maioria dos sócios implica justamente deliberação assemblear.” (grifo no original) in H. VERÇOSA, Curso de Direito Comercial, vol. 2, p. 157.

${ }^{13}$ Em relação ao regime anterior à vigência do Código Civil de 2002, Egberto Lacerda Teixeira já defendia vigorosamente a legitimidade ativa da sociedade em matéria de exclusão: “...não vemos muita consistência na afirmação de que a deliberação de exclusão deve ser dos sócios e não da sociedade. Evidentemente, a decisão colegial há de ser tomada pelos sócios, em assembléia ou em instrumento escrito à parte. Uma vez tomada, contudo, a decisão passa a ser da sociedade tanto quanto dos sócios.” in E. TEIXEIRA, Das Sociedades por Quotas de Responsabilidade Limitada, p. 289.
} 
respectivos pressupostos legais. A maioria social forma-se em conclave devidamente convocado, no qual todos os sócios possam, se não votar, ao menos intervir para debater as questões constantes da ordem do dia. Os atos da assembléia ou reunião são atos da própria sociedade e não dos sócios individualmente. O ato do órgão é ato da própria pessoa jurídica $^{14}$.

Poder-se-ia, em resposta, argumentar que o artigo 1.030 estabeleceu uma espécie de substituição processual da sociedade em favor dos sócios. Tal argumento, contudo, não soa particularmente convincente. Em primeiro lugar, tal tese não explica satisfatoriamente como a sociedade, sem tomar parte diretamente no procedimento, possa ser responsabilizada pelo pagamento dos haveres do excluído.

Além disso, caso se tratasse de uma substituição processual com o objetivo de tutelar os interesses da sociedade em situação de urgência, seria mais conveniente atribuir a um sócio individualmente o poder de recorrer à autoridade judiciária em nome da sociedade, consoante o que se verifica entre as sociedades por ações, e não exigir a adesão da maioria.

\subsubsection{Prazo para a Exclusão e para a Reação à Exclusão}

O Código Civil de 2002 não estabeleceu expressamente prazos específicos para o exercício, por parte da sociedade, da pretensão à exclusão facultativa.

Ao discutir a aplicação do instituto da resolução do contrato por inadimplemento no âmbito dos contratos bilaterais, Araken de Assis já registrava que, na ausência de outros critérios legais, a doutrina buscou contornar a questão com o entendimento de que o exercício da prerrogativa de resolução contratual teria como limite temporal a prescrição do direito subjacente respectivamente violado ${ }^{15}$.

Trata-se, não obstante, de uma solução que é inaplicável não somente ao contrato plurilateral de sociedades, mas aos contratos de longa duração e trato sucessivo em geral, como reconheceu o próprio autor. Para o ilustre estudioso, contudo, a questão não teria maior gravidade, porque seria "implausível” que o credor prejudicado não se mobilizasse

\footnotetext{
${ }^{14}$ F. MIRANDA, Tratado de Direito Privado, Parte Geral, Tomo I, p. 290.

${ }^{15}$ A. ASSIS, Resolução do Contrato por Inadimplemento, p. 153-154.
} 
imediatamente contra o inadimplemento ${ }^{16}$. Entretanto, no âmbito dos contratos plurilaterais, especialmente no que tange a sociedade, tal argumento soa particularmente débil.

No que diz respeito à exclusão judicial (artigo 1.030, caput), o termo inicial do prazo de prescrição da respectiva ação seria a data em que nasce para a sociedade a pretensão à expulsão, nos termos do artigo 189 do Código Civil de 2002. Isso significa o momento em que se verifica o grave inadimplemento do excluendo. Salvo no caso de exclusão motivada por infração cometida pelo sócio sob as vestes de “administrador” ou “fiscal” - a qual poderia se subsumir à hipótese prevista pelo artigo 206, parágrafo $3^{\circ}$, inciso VII, alínea “b” -, tal medida judicial não se enquadra nitidamente sob nenhuma das hipóteses do artigo 206 do próprio Código Civil, cabendo argumentar, portanto, que seria aplicável o (desarrazoado) prazo geral de dez anos previsto pelo artigo 205.

Em relação à exclusão extrajudicial, a questão é ainda mais incerta, pois esta consiste em prerrogativa contratual e as regras atinentes à prescrição somente poderiam ser aplicadas por meio de um duvidoso recurso à analogia.

De qualquer modo, é importante ter sempre presente que a exclusão é um mecanismo que tem por objetivo a defesa da empresa, por meio da tutela dos interesses sociedade, e não pode representar um trunfo estratégico em favor da maioria social, a ser trazido à tona quando e se julgado conveniente. Com efeito, a questão do momento em que é exercida a pretensão à exclusão extrapola aspectos processuais e procedimentais e diz respeito ao próprio sentido do direito material à exclusão do sócio.

Verificado um grave inadimplemento contra a sociedade, espera-se que esta - se necessário, impelida por deliberação dos sócios adimplentes - reaja prontamente à questão e não titubeie ao tomar as medidas cabíveis contra o sócio infrator. Em princípio, deve-se recorrer ao mecanismo da exclusão (i) assim que verificada falta grave ou (ii) quando exaurido prazo razoável concedido ao excluendo para sanar o respectivo problema.

\footnotetext{
16 “...nos contratos de duração a falta de prazo não afigura tão desvantajosa. Espera-se uma reação quase imediata ao inadimplemento, seja resilindo o vínculo, seja pleiteando a prestação em juízo. É implausível que o locador aguarde indefinidamente o pagamento dos alugueres, por exemplo, embora seja possível que, perante as circunstâncias do caso concreto, tolere o atraso por alguns meses.” in A. de ASSIS, Resolução do Contrato por Inadimplemento, p. 153-154.
} 
Os sócios adimplentes não podem “armazenar” faltas graves de seus consócios, para argüilas somente quando julgarem adequado, em circunstâncias não relacionadas com o anterior inadimplemento. Tal como, por exemplo, na iminência da concretização de vantajosa transação comercial, evitando assim compartilhar com o sócio excluendo os respectivos lucros.

Permitir que, meses ou anos após o exaurimento de uma situação de inadimplemento grave, a respectiva questão seja levantada de forma oportunista pela maioria social para, absolutamente fora de contexto, excluir um consócio significaria consagrar o abuso de direito e a arbitrariedade. Tal fato é inaceitável, não porque ultrapassa prazos prescricionais ou contratuais específicos, mas porque esvazia de conteúdo a respectiva justa causa e desvirtua o sentido do instituto da exclusão de sócio, que existe para a tutela do interesse da sociedade e não da maioria social.

Nesse sentido, cumpre entender que o direito de pleitear a exclusão de um sócio por inadimplemento deve ser exercido dentro de prazo “razoável”, determinável apenas em face das condições concretas de uma determinada situação. É plausível, por exemplo, que uma sociedade decida aguardar meses, para acompanhar o desenvolvimento de grave moléstia de um sócio - que o tenha reduzido a situação de incapacidade -, antes de concluir definitivamente se tal estado é irreversível ou não. Por outro lado, em situações como a verificação de alegação de apropriação indébita de bens da sociedade, não parece admissível que a sociedade permaneça inerte por igual período.

Um outro possível exemplo de uso extemporâneo do mecanismo da exclusão seria o caso em que um sócio exerça, por determinado período, atividade concorrente à da sociedade, mas esta última pleiteie sua expulsão por suposta concorrência desleal apenas após haver deixado - por motivos alheios à competição indevida do quotista - de atuar naquele mesmo ramo.

No que diz respeito ao prazo para a reação do excluendo contra a sociedade, tratando-se de procedimento judicial, o sócio deverá simplesmente apresentar sua contestação e propor eventuais recursos nos prazos indicados em lei. Se, por outro lado, a exclusão houver sido processada de forma extrajudicial, por meio de deliberação dos sócios (nos termos do 
artigo 1.085 do Código Civil de 2002), o excluído terá em princípio o prazo de três anos para propor ação com o objetivo de pleitear sua readmissão na sociedade, em conformidade ao disposto no parágrafo único do artigo 48 do Código Civil de 2002.

É necessário ter em conta, contudo, o efeito de eventual adoção das normas da sociedade anônima como regime supletivo, nos termos do parágrafo único do artigo 1.053 do Código Civil de 2002. Não é totalmente claro se em tal hipótese prevalece o prazo trienal previsto pelo artigo 48, parágrafo único, do próprio Código, ou o termo bienal consignado pelo artigo 286 da Lei $n^{\circ}$ 6.404/76. Tendo em vista o caráter especial deste último diploma, parece razoável argumentar que a regra da lei acionária derrogue a aplicação do prazo de três anos. Trata-se de mais um entre os tantos pontos de incerteza criados pelo complexo sistema de remissões estabelecido pelo Livro da Empresa.

Em um ou em outro caso, existirá dúvida quanto ao termo inicial do prazo de prescrição. Para Waldecy Lucena, não sendo a sociedade limitada obrigada a publicar seus instrumentos de deliberação, o prazo em questão teria início inequivocamente na data de registro do ato de exclusão perante a Junta Comercial competente (ou Registro Civil das Pessoas Jurídicas, no caso de sociedade simples constituída sob a forma de sociedade empresária) ${ }^{17}$.

Ocorre, todavia, que o ato societário produz em regra efeitos imediatos entre os sócios, servindo o registro público somente para criar uma presunção de conhecimento entre terceiros. Caso, por exemplo, o excluído esteja presente na assembléia que deliberar a exclusão, não deverá aguardar o arquivamento da respectiva ata antes de propor medida judicial finalizada a resguardar os próprios direitos. Em tal situação, o excluído poderia em tese exigir cópia autenticada da ata, nos termos do artigo 175, parágrafo $3^{\circ}$, do Código Civil de 2002, e com base em tal documento pleitear a nulidade da deliberação de seus consócios.

Caso se admita que a pretensão do quotista presente à assembléia ou reunião à própria reintegração no quadro de sócios nasce logo após a deliberação de exclusão, este seria o

\footnotetext{
${ }^{17}$ J. LUCENA, Das Sociedades Limitadas, p. 597. No mesmo sentido: M. CARVALHOSA, Comentários ao Código Civil - Parte Especial do Direito de Empresa, p. 321.
} 
termo inicial de contagem do prazo de prescrição, nos termos do artigo 189 do Código Civil de 2002.

O aspecto mais importante, de qualquer modo, é que mesmo o prazo de dois anos apropriado do regime das sociedades anônimas é excessivamente longo e incompatível com o dinamismo da atividade empresarial. É assombroso pensar que um sócio possa, literalmente anos após sua exclusão extrajudicial, exigir a sua reintegração na sociedade.

\subsubsection{Exclusão Judicial}

No ordenamento italiano, entre as sociedades de pessoas, a exclusão é tradicionalmente uma medida tomada pela sociedade, mediante deliberação dos sócios, em via extrajudicial, consoante o artigo 2.286 do Código Civil de 1942. O procedimento de exclusão judicial é imposto pela lei apenas em relação à exclusão na sociedade com dois sócios, nos termos do artigo 2.287 .

No regime brasileiro anterior à promulgação do Código Civil de 2002, a despeito de inúmeras idas e vindas doutrinárias e jurisprudenciais, a possibilidade de exclusão extrajudicial era tida como a regra geral. Como já indicado anteriormente, as normas atinentes ao registro das empresas mercantis previam que a exclusão apenas não poderia ser aprovada extrajudicialmente caso existisse no contrato social cláusula restritiva de deliberação majoritária ${ }^{18}$. Tal fato deriva da própria origem do instituto no Brasil, aceito pela primeira vez como uma manifestação da liberdade contratual ${ }^{19}$. Nesse sentido, a exclusão de sócio no Brasil já nasceu sob a veste de procedimento extrajudicial.

Todavia, em linha com seu espírito garantístico e com seu objetivo de oferecer maior proteção aos quotistas minoritários, o Código Civil de 2002 caminhou em sentido contrário à tradição brasileira e transformou em exceção o que antes representava a regra geral. De fato, no atual sistema, a exclusão extrajudicial não é admitida entre as sociedades de pessoas puras (sociedade simples, em nome coletivo e em comandita simples), sendo

\footnotetext{
${ }^{18}$ Artigo 35, inciso VI, da Lei Federal 8.934 e artigo 54 do Decreto 1.800/96.

19 "Nas sociedades que estudamos, o rito a seguir é este: constatada a falta do socio, os demais pronunciarão a sua exclusão, em documentos devidamente assignado, e dessa resolução darão conhecimento ao socio excluido, por meio de uma notificação judicial ou por qualquer outro que possa ser provado.” in S. FARIA, Da Exclusão de Socios na Sociedades de Responsabilidade Illimitada, p. 32.
} 
possível entre as sociedades limitadas somente mediante o atendimento de determinadas condições, como a existência de cláusula expressa no contrato social.

De qualquer forma, o legislador de 2002 ao menos ressalvou, por referência explícita contida no artigo 1.085, a aplicação do artigo 1.030 às sociedades limitadas. Desse modo, a ausência dos pressupostos necessários à exclusão extrajudicial não implica a própria inviabilidade da aplicação do instituto da exclusão em si, mas simplesmente obriga a sociedade a recorrer à via judicial.

O principal requisito prévio à proposição da ação de exclusão por parte da sociedade é a aprovação dos sócios. Tal deliberação deve ser tomada sem contar os votos do sócio excluendo, tanto porque o caput do artigo 1.030 refere-se à “maioria dos demais sócios”, quanto pelo fato de que o sócio que se busca excluir estaria impedido de votar por uma questão de conflito de interesse, consoante o artigo 1.074, parágrafo $2^{\circ}$. Uma vez que, contrariamente ao artigo 1.085, não há referência à necessidade de maioria absoluta ou qualificada, a autorização para propor judicial a ação para pleitear a exclusão de um consócio poderá ser aprovada por maioria simples entre os presentes ao conclave (artigo 1.076, inciso III), mas desde que satisfeito o quorum mínimo de instalação previsto pelo artigo 1.074 .

Em decisão recente, o Superior Tribunal de Justiça entendeu que, em uma sociedade limitada com apenas dois quotistas, cada um deles titular de metade do capital social, não seria necessária a autorização dos sócios em assembléia - resultante da aplicação supletiva do artigo 159 da Lei Federal n 6.404/76 - para se promover ação de indenização (e, frisese, não de exclusão) contra o sócio-administrador ${ }^{20}$. O acórdão se refere a um conflito que veio à tona ainda na vigência do Decreto 3.708/19, mas a discussão é válida também no âmbito do Código Civil de $2002^{21}$.

\footnotetext{
20 "Não se pode aplicar a regra contida no art. 18 do 3.708/19 automaticamente, sem examinar a natureza jurídica específica da sociedade por quotas de responsabilidade limitada que se encontra em litígio. Havendo incompatibilidade entre a natureza específica da sociedade recorrente e as normas supletivas da Lei 6.404/76, não se pode erigir a realização de reunião prévia de quotistas à condição de pressuposto processual objetivo externo.” in STJ, Recurso Especial n 736.189-RS, Rel. Exma. Min. Nancy Andrighi, D.J.U. 18/12/2007.

${ }^{21}$ O próprio acórdão em questão indica que "Embora seja certo que o Código Civil de 2002 tenha abandonado a fórmula sintética de regulamentação das limitadas, [...], é certo que o novo diploma também é silente no que diz respeito aos procedimentos necessários para a responsabilização do administrador.” in STJ, Recurso Especial n 736.189-RS, Rel. Exma. Min. Nancy Andrighi, D.J.U. 18/12/2007.
} 
A base da argumentação da referida decisão reside na informalidade típica das sociedades limitadas (in casu sociedade por quotas) e na alegada inutilidade de eventual reunião ou assembléia, pois o sócio administrador - réu da causa a ser proposta - estaria impedido de votar por conflito de interesse. Tal argumento não se aplica, contudo, à exclusão judicial de sócio, pois a necessidade de prévia deliberação é mencionada no próprio caput do artigo 1.030, norma incorporada ao regime das sociedades limitadas por força da remissão expressa contido no artigo 1.085 do Código Civil de 2002.

A deliberação de autorização para a propositura de ação de exclusão, contrariamente à aprovação da expulsão extrajudicial nos termos do artigo 1.085, não implica diretamente uma mudança no contrato social - a qual dependerá de eventual e futura sentença judicial no respectivo processo -, nem tampouco se enquadra nas outras hipóteses previstas pelo artigo 1.077 do mesmo diploma. Nesse sentido, em princípio, não pode o sócio que discordar de tal deliberação exercer direito de recesso, ressalvada uma interpretação extremamente extensiva do dispositivo em questão.

Sucessivamente à aprovação dos sócios, caberá à sociedade, na pessoa de seus administradores, outorgar poderes a um advogado e dar início à ação de exclusão. Como discutido anteriormente, a sociedade pleiteia diretamente o exercício de direito próprio e não se vislumbra razão para a existência de litisconsórcio ativo necessário entre a sociedade e os sócios adimplentes ${ }^{22}$. Estes últimos, caso se sintam pessoal e diretamente atingidos pela conduta do excluendo ${ }^{23}$, poderão tomar parte na ação em litisconsórcio ativo facultativo, em função da identidade de fundamento de fato, nos termos do artigo 46, inciso II, do Código de Processo Civil.

O foro para a ação de exclusão será em princípio o do domicílio do sócio excluendo, nos termos do artigo 94 do Código de Processo Civil. Todavia, para evitar que eventual mudança no domicílio do sócio obrigue a sociedade a promover a causa em local distante

\footnotetext{
${ }^{22}$ Em sentido contrário, manifestou-se a Professora Priscila Corrêa da Fonseca. P. FONSECA, Dissolução Parcial, Retirada e Exclusão de Sócio, p. 112. Exatamente por tal questão e com a devida vênia, discorda-se também da ilustre professora no que tange à sua defesa da possibilidade de propor a ação exclusão do sócio perante juizado especial cível, nos termos da Lei Federal 9.099/95 (P. FONSECA, Dissolução Parcial, Retirada e Exclusão de Sócio, p. 91). Independentemente do valor da causa, nos termos do artigo $8^{\circ}$, parágrafo $1^{\circ}$, a proposição de ação perante juizado especial cível é reservada às pessoas físicas.

${ }^{23}$ Ou seja, caso sofram outros danos que não a perda de valor da participação detida na sociedade, pois esta representa um dano reflexo cujo ressarcimento deve ser exigido pelo próprio ente social.
} 
ou remoto, é lícita e aconselhável a eleição de foro específico, por meio de cláusula expressa do contrato social ${ }^{24}$.

Em relação ao valor da causa, o inciso V, do artigo 259, do Código de Processo Civil determina que em caso "rescisão de negócio jurídico" deve-se tomar como parâmetro o montante do contrato em questão. Trata-se da previsão que mais se aproxima da hipótese de exclusão facultativa de sócio, a qual representa uma forma particular de resolução contratual.

Existem, contudo, duas questões que devem ser tomadas em consideração para a aplicação de tal preceito à exclusão. Em primeiro lugar, é apenas o vínculo entre a sociedade e o excluído que se busca romper, não todo o contrato de sociedade, como no caso da típica resolução por inadimplemento. O segundo aspecto é que, no momento em que a demanda é apresentada, normalmente não se conhece ainda o valor dos haveres devidos ao excluído, questão que na maioria dos casos deve ser verificada por meio de posterior perícia contábil. Nesse sentido, a melhor resposta parece ser a de que o valor da causa corresponda ao valor estimado dos haveres devidos ao excluendo ${ }^{25}$.

É importante recordar que, evidentemente, a condução da exclusão de um sócio por meio de procedimento arbitral não tem o condão de tornar a expulsão “extrajudicial”. A exclusão extrajudicial é aquela levada a cabo pelos próprios sócios, por força de deliberação social. O tribunal arbitral atua, para todos os efeitos, como autoridade judicial (artigo 18 da Lei Federal $n^{\circ}$ 9.307/96) e tal processo de exclusão deve ser conduzido nos termos do artigo 1.030, caput, do Código Civil de 2002, sem se confundir o procedimento estabelecido no artigo 1.085 do mesmo diploma.

\subsubsection{Exclusão Extrajudicial}

Ao lado da exclusão judicial, o Código Civil de 2002 manteve a possibilidade de exclusão do quotista por meio de simples deliberação dos sócios. Já não se trata, contudo, do mesmo

\footnotetext{
24 “Nem no regime anterior nem no novo regime do Código Civil há qualquer disposição que impeça os sócios das sociedades limitadas de estabelecer cláusula de eleição de foro para dirimir suas desavenças.” STJ, Recurso Especial n 684.760-AM, Rel. Exmo. Min. Carlos Alberto Menezes Direito, D.J.U. 06/08/2007.

25 "Em se tratando, porém, de dissolução parcial ou exclusão de sócio, o valor da causa deve corresponder ao montante das cotas e haveres do sócio a ser excluído.” TJRJ, Agravo de Instrumento n 2008.002.01085, Rel. Exmo. Des. Carlos Santos de Oliveira, 16/01/2008. P. FONSECA, Dissolução Parcial, Retirada e Exclusão de Sócio, p. 128.
} 
procedimento anterior à vigência da nova lei. Na nova sistemática, a exclusão extrajudicial já não é mais a regra, o procedimento padrão. Condicionada a diversos requisitos e encerrada em procedimento assemblear muito mais complexo, como indicado a seguir, a exclusão pronunciada pela própria sociedade, por meio de deliberação dos sócios adimplentes, tende a ser a exceção.

\subsubsection{Previsão Contratual Expressa}

Com a expressão “...mediante alteração do contrato social, desde que prevista neste a exclusão por justa causa”, o artigo 1.085 do Código Civil de 2002 estabelece inequivocamente a existência de cláusula expressa como um dos requisitos essenciais para a admissibilidade do procedimento de exclusão extrajudicial.

Tal disposição representa uma notável reviravolta em relação ao regime vigente imediatamente antes da promulgação do Código Civil de 2002. De fato, na esteira de construções jurisprudenciais e doutrinárias das décadas anteriores, o artigo 54 do Decreto 1.800/96 estabelecia que o arquivamento do ato de deliberação majoritária que determinasse a exclusão de um sócio seria sempre passível de arquivamento, a não ser que existisse no contrato social uma cláusula expressa de restrição ao poder da maioria ${ }^{26}$. Nesse sentido, o silêncio do contrato deixou de significar uma estrada livre à exclusão extrajudicial, para, ao contrário, decretar a impossibilidade do recurso a este procedimento.

O texto da lei é de tal modo incisivo que não se vislumbra margem para interpretações ampliativas, sobretudo porque o próprio artigo 1.085 ressalvou a aplicação do artigo 1.030 do Código Civil de 2002 às sociedades limitadas. Assim, a ausência de cláusula expressa no contrato social representa um obstáculo apenas para a exclusão pela via extrajudicial, mas não inviabiliza a aplicação da exclusão em $\mathrm{si}^{27}$.

\footnotetext{
${ }^{26}$ Modesto Carvalhosa vê na exigência de cláusula expressa de exclusão, imposta pelo novo diploma, um "evidente retrocesso" em relação à prática anteriormente consolidada pela doutrina e jurisprudência. M. CARVALHOSA, Comentários ao Código Civil - Parte Especial do Direito de Empresa, p. 308 e 312.

${ }^{27}$ Diversamente do que ocorre com a sociedade limitada italiana. Quando o direito de exclusão foi finalmente estendido à società a responsabilità limitata, com a reforma de 2003, a existência de previsão contratual expressa foi posta como condição essencial à própria aplicabilidade do instituto, nos termos do artigo 2.473 bis.
} 
Se, de um lado, não existe dúvida sobre a necessidade de cláusula expressa para a admissibilidade da exclusão extrajudicial ${ }^{28}$, não restam de todo claro, todavia, o conteúdo e o nível mínimo de detalhe de tal disposição, nem o momento em que pode ser aprovada e inserida no contrato social.

A ratio por trás da exigência de previsão contratual para a admissão da exclusão extrajudicial parece ser a de simplesmente registrar o consenso dos minoritários em relação a tal procedimento e não disciplinar todos os seus pormenores.

A exclusão extrajudicial, como já discutido no Capítulo 2, representa uma grave e relevante inversão do ônus do recurso ao Judiciário, impondo ao excluído o fardo de propor a competente ação caso entenda que sua expulsão foi injusta. O principal resultado prático da adoção do procedimento em questão é o fato de que um quotista pode ser privado da qualidade de sócio antes mesmo que um juiz tenha a oportunidade de avaliar a sua situação jurídica. Dessa forma, dada a relevância da matéria e as conseqüências que comporta, faz sentido que o legislador tenha condicionado a aplicabilidade do procedimento de exclusão extrajudicial ao consentimento expresso dos sócios.

Além disso, é importante ter em consideração que os artigos 1.085 e 1.086 do Código Civil de 2002, somados às normas gerais de deliberação da sociedade limitada, contemplam substancialmente todas as regras necessárias para consumar a exclusão do sócio por força de decisão de seus consócios. Não é destarte imprescindível que a disciplina legal do procedimento de exclusão extrajudicial seja de qualquer forma complementada por disposições do contrato social.

Sob esta ótica, pode-se concluir que a previsão contratual expressa mencionada pelo caput do artigo 1.085 não representa mais do que uma mera autorização para a condução da exclusão pela via extrajudicial. Enquanto tal, a cláusula tem de indicar a aceitação do procedimento extrajudicial pelos sócios, mas não deve obrigatoriamente discipliná-lo nem

\footnotetext{
${ }^{28}$ Em sentido contrário, ou seja, em favor da admissibilidade da exclusão extrajudicial mesmo na ausência de cláusula expressa no contrato social: "Somos francamente favoráveis a que a exclusão se opere extrajudicialmente, por ato da sociedade, independentemente de figurar ou não, ao contrato social, cláusula resolutória expressa a respeito da exclusão.” in J. LUCENA, Das Sociedades Limitadas, p. 755.
} 
indicar expressamente as causas justificadas que ensejam a exclusão por meio de deliberação social ${ }^{29}$.

Os sócios não estão obrigados a estipular explicitamente as razões que podem justificar a adoção do regime da exclusão extrajudicial e nem é conveniente que o façam, pois nenhum rol exaustivo de causas de expulsão compreenderia todas as possibilidades de grave inadimplemento do sócio que podem surgir no quotidiano da atividade empresarial. A este respeito, recorda-se que o próprio legislador absteve-se de delimitar antecipadamente todas as hipóteses de exclusão.

Exigir que a cláusula de exclusão presente no contrato social discipline quaisquer aspectos da expulsão de sócio pela via extrajudicial seria impor restrições, quando a própria lei não o fez. Isso não significa, naturalmente, que os sócios não tenham a liberdade para, dentro dos limites postos pelas normas cogentes, regular a exclusão extrajudicial.

Os sócios podem optar por uma cláusula enxuta ou disciplinar em todos os detalhes os procedimentos, prazos e causas de exclusão extrajudicial. Ou ainda, como alternativa, podem adotar uma disciplina mista, que inclua um rol apenas exemplificativo dos motivos que ensejam a expulsão pela via extrajudicial.

O regime contratual que estabeleça a adoção da exclusão extrajudicial de forma restrita a determinados casos deve ser entendido meramente como o exercício parcial da faculdade concedida pela lei aos sócios e não como uma renúncia ou limitação à própria possibilidade de exclusão. Valer-se, integralmente ou não, da prerrogativa prevista no artigo 1.085 não significa renunciar ao regime previsto pelo artigo 1.030, inclusive porque aquele dispositivo ressalva expressamente a aplicação deste último.

Caso se verifique uma hipótese de grave inadimplemento do sócio, danosa à atividade empresarial, mas não prevista por uma cláusula de exclusão extrajudicial numerus clausus, a sociedade poderá de qualquer modo recorrer à expulsão pela via judicial. Entender a

29 “...essa cláusula não precisa especificar as hipóteses de justa causa, podendo limitar-se à previsão genérica de exclusão do sócio, desde que legitimamente motivada.” in M. CARVALHOSA, Comentários ao Código Civil - Parte Especial do Direito de Empresa, p. 315. 
questão de modo diverso, equivaleria a aceitar a cláusula de proibição da exclusão, o que não parece possível, como discutido no Capítulo 7.

Um outro aspecto relevante nessa matéria consiste na aprovação superveniente, ou seja, após a constituição da sociedade e por meio de alteração do contrato social, da cláusula expressa de exclusão extrajudicial. Não parece haver razão convincente para argumentar que os sócios não possam modificar o contrato social para a introdução de tal cláusula. Em razão do princípio majoritário, uma vez aprovada tal disposição, ela será válida e vinculante, inclusive em relação aos sócios que tenham discordado da respectiva deliberação ou não tenham comparecido ao conclave, nos termos do artigo 1.072, parágrafo 5², do Código Civil de 2002.

Esse fato levou Assis Gonçalves a argumentar que a aprovação da cláusula de exclusão e a respectiva expulsão extrajudicial do sócio poderiam ocorrer em único conclave ${ }^{30}$. Tal tese, contudo, parece exagerada e sua aceitação implicaria substancialmente o esvaziamento de quase todo o sentido da própria exigência de previsão contratual expressa. A situação do sócio minoritário seria, na maioria dos casos, idêntica, havendo ou não cláusula expressa de exclusão extrajudicial nos atos constitutivos, pois tal disposição poderia ser convenientemente introduzida no contrato social pela maioria societária a qualquer momento.

De fato, sob tal perspectiva, o requisito da cláusula contratual expressa ofereceria alguma proteção tão-somente ao sócio minoritário com participação superior a um quarto do capital social e que, portanto, seria capaz de impedir a aprovação de alterações do contrato social, nos termos do artigo 1.076, inciso I, do Código Civil, combinado com o artigo 1.071, inciso V. Afinal, apenas tal sócio teria a possibilidade de vetar a introdução no contrato social da cláusula autorizadora da expulsão extrajudicial, eventualmente proposta por seus consócios.

\footnotetext{
30 "De qualquer forma, se a maioria possuir percentual suficiente para alterar o capital social, nada impede que a sociedade tome, desde logo, essa deliberação, já que, no meu entender, o que é possível em duas assentadas (alteração contratual para prever a possibilidade de exclusão por justa causa, seguida de deliberação nesse sentido), pode ocorrer em uma só." in A. GONÇALVES NETO, Lições de Direito Societário, p. 297.
} 
A primeira objeção que se pode levantar à posição defendida por Assis Gonçalves diz respeito à possibilidade de se incluir tanto a proposta de introdução da cláusula de exclusão extrajudicial quanto a própria expulsão do sócio na ordem do dia do mesmo conclave. Ao disciplinar a assembléia ou reunião de exclusão extrajudicial, o artigo 1.085 determina claramente que o conclave deve ser especialmente convocado para tal propósito. Como se discute mais detalhadamente a seguir, tal disposição sugere que, em função da importância da matéria, outras questões não podem disputar espaço com a deliberação da exclusão.

Ademais, causa espécie a idéia de que a cláusula de exclusão extrajudicial possa ser aplicada a episódios de inadimplemento do sócio anteriores à própria aprovação da disposição contratual em questão. Tal operação exigiria uma canhestra equiparação da cláusula de exclusão a uma norma processual e, de qualquer modo, representaria um grave dano à segurança jurídica dos sócios minoritários.

Os atos de um sócio devem, em princípio, ser avaliados sob a luz das disposições contratuais em vigor no momento em que são praticados. Assim, ainda que fosse possível aprovar, em um único conclave, tanto a introdução da cláusula em questão no contrato social quanto a própria expulsão do sócio, a sua exclusão teria de se basear em uma causa de efeito permanente, tal como a incapacidade irreversível por moléstia grave, e não em fatos anteriores à respectiva assembléia ou reunião.

É importante, por fim, observar que a introdução da cláusula de exclusão em concomitância com a expulsão extrajudicial de um quotista, representaria grave dano para o exercício do direito de recesso, nos termos do artigo 1.077 do Código Civil de 2002, não apenas por parte do excluendo, mas por todos os sócios discordantes. De fato, os sócios minoritários podem se sentir ameaçados pela introdução da possibilidade de exclusão extrajudicial e, conseqüentemente, optar por abandonar a sociedade por iniciativa própria. Cumpre recordar, a esse respeito, que a resolução do vínculo com a sociedade por meio do recesso ou da exclusão não são equivalentes para o sócio, sobretudo sob uma perspectiva de imagem e reputação. 


\subsubsection{Reunião e Assembléia de Exclusão e "Defesa” do Excluendo}

O Código Civil de 2002 estabeleceu três regimes básicos de deliberação dos sócios no âmbito da sociedade limitada: (i) a deliberação por instrumento escrito, (ii) a reunião e (iii) a assembléia de quotistas. Esta última é a forma mais rigorosa e garantística de conclave e se aproxima da assembléia de acionistas em termos de formalidades de convocação, representação do sócio e instalação (artigos 1.074 e 1.075).

A “reunião", por outro lado, representa uma faculdade, outorgada pelo legislador aos sócios, de estabelecer no contrato social um regime de deliberação simplificado, mas ainda assim assemblear, que pode ser livremente moldado - desde que não comporte prejuízo aos direitos essenciais dos quotistas - de acordo com as necessidades da sociedade ${ }^{31}$. Assim, apenas como exemplo, na reunião de sócios é teoricamente possível estabelecer a convocação por meio de carta registrada, ao invés da onerosa - sobretudo para micro e pequenas empresas - publicação de editais, uma formalidade essencial à assembléia (ressalvada, evidentemente, a presença de todos os sócios). A todos os aspectos da reunião que não forem expressamente disciplinados pelo contrato social, aplicam-se as regras da assembléia, consoante o disposto no parágrafo $6^{\circ}$, artigo 1.072 .

A deliberação por instrumento escrito, a seu turno, representa uma forma ainda mais simples de deliberação, sem natureza assemblear - ou seja, não tomada necessariamente através a realização de um conclave -, mas tem como requisito fundamental que todos os quotistas assinem o respectivo instrumento. É importante recordar que a lei não exige propriamente a unanimidade, o que significa que teoricamente um quotista poderia assinar o documento registrando expressamente a sua discordância.

Ao determinar que a deliberação de exclusão extrajudicial deve ser aprovada por meio de reunião ou assembléia, o artigo 1.085 traz consigo duas conseqüências principais. A primeira é excluir a possibilidade de se aprovar a exclusão extrajudicial por meio de instrumento escrito. De fato, tal forma de deliberação teria como obstáculo quase

\footnotetext{
31 “Em tese, as reuniões ficam sujeitas a um grau menos intenso de formalidades, considerando-se que o pequeno número de sócios deve determinar maior convivência diária - e, portanto, acompanhamento permanente, por eles, das atividades da sociedade. Mas, para que isto aconteça será necessário que o contrato social estabeleça as condições para a realização das aludidas reuniões. Diante da inexistência ou da omissão de regras a respeito das reuniões, a estas será aplicado autonomamente o regramento previsto para as assembléias...” in H. VERÇOSA, Curso de Direito Comercial, vol. 2, p. 495.
} 
insuperável a necessidade de assinatura do sócio excluído e, de qualquer modo, privaria este último da oportunidade apresentar aos consócios os seus possíveis argumentos contrários à exclusão. A segunda conseqüência relevante é que tal disposição assegura a possibilidade de aprovar a exclusão por meio da mais flexível reunião de sócios, confirmando que tal deliberação não está compreendida no campo de decisões que podem ser tomadas exclusivamente por meio de assembléia. Não obstante, caso a sociedade possua mais de dez quotistas, a deliberação deverá necessariamente ocorrer por meio de assembléia (artigo 1.072, parágrafo $1^{\circ}$ ).

O parágrafo único do artigo 1.085 determina que as assembléias ou reuniões destinadas a apreciar a exclusão de um sócio devem ser especialmente convocadas para esse fim. Isso significa, em primeiro lugar, que não se aplica ao conclave de exclusão a possibilidade de dispensa de convocação, prevista pelo parágrafo $2^{\circ}$, do artigo 1.072 . Se o contrato social não prever a deliberação por meio de reunião, não determinar regras de convocação simplificadas para esta última ou estabelecer restrição ao uso de tal regime de deliberação em relação à exclusão de sócio, a convocação deverá ser realizada pela publicação de editais, nos termos do parágrafo $3^{\circ}$, do artigo 1.152 .

Ao se referir a conclave especialmente convocado para o fim da exclusão, o parágrafo único do artigo 1.085 também determina que a ordem do dia da respectiva assembléia ou reunião não pode conter matérias estranhas à própria questão da expulsão do sócio. Devido à relevância de tal questão, o legislador optou por não permitir que outros argumentos e problemas disputassem a atenção dos sócios. A ordem do dia do conclave de exclusão deve tratar exclusivamente da expulsão do excluendo e de questões a ela diretamente relacionadas, tais como a destituição do cargo de administração do sócio, em caso de efetiva exclusão. A especialidade da ordem do dia no conclave de exclusão é um importante instrumento contra o uso da ameaça de exclusão como chantagem. Tal disposição tem o mérito de impedir que sócios incluam outras matérias de seu próprio interesse na ordem do dia ao lado da proposta de exclusão e, abertamente ou de forma implícita, condicionem a reprovação desta à aceitação daquelas por parte do excluendo.

Ao indicar a ordem do dia, o instrumento de convocação deve ainda sucintamente mencionar a causa que pode justificar a possível exclusão, objeto do conclave. Nesse ponto é necessário enfrentar um dos aspectos mais delicados da exclusão extrajudicial, que diz 
respeito à própria natureza do conclave que tenha por objetivo apreciar a expulsão de um sócio. O parágrafo único do artigo 1.085 referiu-se, de forma canhestra e não técnica, ao exercício de direito de defesa por parte do excluendo, transmitindo a equivocada idéia de que a assembléia ou reunião de exclusão possam representar uma forma de julgamento, o que é absolutamente inaceitável ${ }^{32}$.

Como discutido anteriormente (Capítulos 2 e 3), a exclusão não representa uma penalidade, mas o simples exercício de uma prerrogativa contratual, uma manifestação específica, adaptada ao contrato plurilateral de sociedade, do preceito geral da resolução do contrato por inadimplemento. Enquanto tal, a deliberação no sentido de romper o vínculo contratual com um dos sócios não é nada mais do que parte do processo de formação da vontade social. O conclave de exclusão é órgão da sociedade. A realização da assembléia ou da reunião não se presta a “julgar” o excluendo, mas simplesmente a determinar qual é a vontade da sociedade, exercer ou não uma prerrogativa a ela atribuída pela lei.

A única razão pela qual a deliberação dos sócios é necessária em tal caso é porque se trata de ato extremamente relevante, que nos mais das vezes acarreta dano ao patrimônio social, visto a necessidade de pagar os haveres do excluído. A exigência de prévia deliberação dos sócios não representa, contudo, característica exclusiva do ato de exclusão extrajudicial. A aprovação prévia dos sócios é necessária à prática de todos os atos relacionados no artigo 1.071 do Código Civil de 2002, e tal lista pode ser ampliada por disposição do contrato social.

O objetivo do conclave de exclusão, seja assembléia, seja reunião, não é condenar o excluendo ou declará-lo inocente, mas sim (i) verificar se estão presentes os pressupostos para o recurso ao remédio da exclusão e (ii) determinar se convém ao melhor interesse da sociedade aplicar tal solução, naquele determinado contexto. O caput do artigo 1.085 determina que a sociedade pode, mas não necessariamente deve, excluir o sócio inadimplente. Com efeito, é perfeitamente plausível que os sócios concluam que a conduta do excluendo seja grave o suficiente para justificar a exclusão, mas decidam que não seja

\footnotetext{
32 “É de fundamental importância esclarecer que a assembléia ou a reunião de sócios não realiza julgamento acerca da conduta do sócio que se deseja excluir. Tem ela tão-somente o poder de deliberar excluí-lo da sociedade, por ato unilateral e extrajudicial, independentemente da concordância do sócio excluído. A sociedade é parte na medida em que é interessada no desfecho da questão.” (grifo no original) in M. CARVALHOSA, Comentários ao Código Civil - Parte Especial do Direito de Empresa, p. 316.
} 
conveniente para a sociedade sofrer uma descapitalização naquele específico momento. $\mathrm{O}$ fato que a decisão de exclusão (facultativa) esteja submetida à conveniência da sociedade, característica essencial desta modalidade de expulsão, coloca em evidência a natureza contratual do instituto e sua incompatibilidade com qualquer analogia ou aproximação ao conceito de julgamento.

Nesse sentido, a interpretação mais razoável que se pode fazer do parágrafo único do artigo 1.085 é a de que, ao se referir ao direito de “defesa” do excluendo, o legislador tratou de assegurar a prerrogativa do sócio de argumentar e apresentar suas razões aos seus consócios $^{33}$. Ao excluendo, cumpre reiterar, cabe exercer meramente o direito de voz, atribuível a qualquer sócio, com o intuito de tentar dissuadir os demais quotistas da decisão de exclusão. O único “contraditório” que se forma no conclave de exclusão é aquele societário-assemblear.

Para que se pudesse entender a referência a “defesa” do parágrafo único do artigo 1.085 do Código Civil de 2002 como uma expressão do direito constitucional de defesa, consagrado pelo artigo $5^{\circ}, \mathrm{XXXV}$, da Constituição Federal, seria necessário elevar o conclave de exclusão a uma forma de julgamento, reconhecendo-o como uma "instância preliminar" do contencioso judicial ou uma forma de tribunal para-arbitral. O mesmo pode-se dizer de qualquer tentativa de sujeitar o conclave de exclusão aos princípios do devido processo legal, disciplinados pelo inciso LV do artigo $5^{\circ}$ da Carta Magna. Tais teses esbarram, contudo, no insuperável obstáculo conceitual da parcialidade dos demais sócios, que os impede de exercer a função de julgadores do excluendo.

Tanto a sociedade quanto os demais sócios são partes diretamente interessadas (inclusive e principalmente sob um ponto de vista econômico) na permanência ou na exclusão de um quotista. A exclusão de um sócio não somente pode acarretar uma significativa alteração

\footnotetext{
33 “O 'direito de defesa' a que canhestramente se refere o parágrafo único [do artigo 1.085] em nada se confunde com o direito constitucional de defesa dado a todos os acusados (art. $5^{\circ}, \mathrm{LV}$, da Constituição Federal), o qual poderá ser eventualmente exercido por esse sócio que vier a atacar o ato de exclusão pela via administrativa, arbitral ou judicial.” in M. CARVALHOSA, Comentários ao Código Civil - Parte Especial do Direito de Empresa, p. 318. No mesmo sentido: "Por direito de defesa deve-se entender, pura e simplesmente, o direito de manifestar-se sobre a justa causa considerada pelos detentores da maioria do capital social para a convocação da reunião ou assembléia de exclusão.” e "Parece-me, de todo modo, extremamente infeliz a previsão de exercício de direito de defesa, já que as deliberações sociais representam, pura e simplesmente, a somatória da vontade da maioria exigida para tomá-la - e não um julgamento.” in A. GONÇALVES NETO, Lições de Direito Societário, p. 300-301.
} 
no equilíbrio de forças interno à sociedade, como inevitavelmente modifica a proporção em que eventuais ganhos futuros serão compartilhados.

Consequentemente, mesmo nos casos em que não se vislumbre uma situação de conflito de interesse, tal qual definido pela legislação societária (e discutido mais adiante), os demais sócios e a sociedade não podem ser considerados aptos a apreciar de forma isenta a conduta do excluendo. Nenhum órgão formado pelos consócios (a assembléia ou a reunião de quotistas) estaria jamais em condições de satisfazer critérios mínimos de independência, imparcialidade e eqüidistância, previstos pelos artigos 135 a 137 do Código de Processo Civil (Lei ${ }^{\circ}$ 5.869/73) ou pelos artigos 13 e 14 da Lei Federal ${ }^{\circ}$ 9.307/96.

Ao apreciar recentemente o caso da exclusão do membro de uma associação, processada de acordo com as regras do estatuto social, mas supostamente em violação ao direito constitucional de “defesa” do associado, o Supremo Tribunal decidiu em favor deste último. A base da argumentação vencedora foi a incidência transversal dos direitos e prerrogativas constitucionais - in casu, o direito de defesa e o princípio do devido processo legal - no âmbito das relações privadas ${ }^{34}$.

No caso discutido, melhor razão assistia, contudo, à relatora original do processo, Ministra Ellen Gracie, que em voto vencido defendeu a liberdade das associações civis de se organizarem e estabelecerem as próprias regras e declarou legítima a exclusão processada de acordo com as disposições do estatuto social. Não se trata de afastar a incidência das normas constitucionais à relações privadas, nem tampouco de negar-lhes eficácia horizontal, mas simplesmente de entender a decisão de exclusão pelo que ela é, uma deliberação que tem por fim a formação da vontade social para o exercício de uma prerrogativa contratual - assegurada expressamente pela lei - e não um julgamento pré ou para-estatal.

\footnotetext{
34 “A ordem jurídico-constitucional brasileira não conferiu a qualquer associação civil a possibilidade de agir à revelia dos princípios inscritos nas leis e, em especial, dos postulados que têm por fundamento direto o próprio texto da Constituição da República, notadamente em tema de proteção às liberdades e garantias fundamentais.” STF, Recurso Extraordinário n 201.819-8, Rel. Exma. Min. Ellen Gracie (voto vencido), Rel. do acórdão Exmo. Min. Gilmar Mendes, D.J.U. 27/10/2006. Em sentido contrário: "Leis, e várias, há, todavia, em que é prevista e assegurada ampla defesa do cidadão, por via do livre exercício de poderes jurídicos, mas no plano do direito público.” in STF, Recurso Extraordinário n 94.999-2, Rel. Exmo. Min. Firmino Paz, D.J.U. 09/10/1981.
} 
Mesmo que fosse o caso de entender como inaceitável a cláusula do estatuto social da associação que tratava da exclusão, a justificativa lógica para considerá-la abusiva seria sua inconformidade à lei, que assegura o direito de argumentação do associado - artigo 57 do Código Civil de 2002, atualmente com a mesma imprecisa referência a direito de defesa presente no parágrafo único do artigo $1.085^{35}$ - e não sua violação do direito constitucional de defesa ou do devido processo legal. Trata-se de uma questão de ilegalidade e não inconstitucionalidade, como fez notar, também em voto vencido, o Exmo Min. Carlos Velloso ${ }^{36}$.

Para se atribuir à associação um dever de respeito a tais prerrogativas constitucionais (direito de defesa e devido processo legal), seria necessário reconhecê-la como titular da capacidade de condenar o associado, o que de fato não ocorre, como discutido acima em relação à sociedade. A deliberação de exclusão simplesmente reconhece uma falta grave do excluendo enquanto pressuposto do exercício do direito de resolução, mas não condena o sócio ou o associado por tal inadimplemento, tanto que não representa título adequado para a exigência do respectivo ressarcimento pelos danos causados, o qual apenas poderá ser pleiteado pela sociedade ou associação em juízo.

Como discutido anteriormente (Capítulo 2), a exclusão extrajudicial tem como elemento principal o fato de promover uma inversão do ônus do recurso ao Judiciário: ao invés de se obrigar a sociedade (ou associação) a solicitar a exclusão perante autoridade judicial, atribuí-se ao sócio excluído o ônus de recorrer aos tribunais para pleitear ressarcimento e buscar a anulação da expulsão, caso a considere injusta. Todavia, tal inversão não significa uma antecipação da tutela judicial. Uma vez que a exclusão extrajudicial representa somente uma dilação, mas não uma supressão, da apreciação da questão pela autoridade judicial, não se pode, tampouco, cogitar de violação do princípio da inafastabilidade da jurisdição (Constituição Federal, artigo 50, inciso XXXV) ${ }^{37}$.

\footnotetext{
${ }^{35} \mathrm{O}$ artigo 57 foi alterado pela Lei Federal $\mathrm{n}^{\circ} 11.127 / 05$ de modo a permitir que as associações pudessem delegar a competência para a exclusão extrajudicial para outros órgãos que não a assembléia geral, cuja convocação é extremamente onerosa para as associações com grande número de associados. Ao fazê-lo, contudo, introduziu a canhestra referência a "defesa”, não presente na redação original do dispositivo.

36 “....a ofensa direta, se ocorrente, seria à lei. No caso, a ofensa direta seria ao Estatuto, o que não deixaria de ensejar ação própria, mas sob o ponto de vista da legalidade. Se formos aplicar o Código civil, ainda assim continua no campo da legalidade ou do contencioso infraconstitucional.” STF, Recurso Extraordinário n ${ }^{\circ}$ 201.819-8, Exmo. Min. Carlos Velloso (voto vencido), D.J.U. 27/10/2006.

37 "A aplicação desse princípio constitucional da universalidade da jurisdição incide, de conseguinte, post factum, assim assegurando o controle jurisdicional da exclusão operada.” in J. LUCENA, Das Sociedades Limitadas, p. 752.
} 
A exclusão é, frise-se, mera forma de resolução contratual. Diferenças à parte, o seu exercício não é, por exemplo, ontologicamente distinto da resolução do contrato bilateral de locação de imóvel por prazo indeterminado, nos termos do parágrafo $2^{\circ}$ do artigo 46 da Lei Federal $n^{\circ} 8.245 / 91$. Verificados determinados requisitos, a lei atribui a uma das partes a prerrogativa de resolver o contrato. Caso a contraparte entenda como injusta ou incabível tal solução, pode recorrer à autoridade judicial, não para solicitar a "reforma” da decisão de resolução, mas para que esta seja declarada nula ou ineficaz.

De qualquer forma, convém registrar que o entendimento atualmente prevalente no Supremo Tribunal Federal, além de não ser unânime, parece circunscrever-se às associações, e, mesmo entre estas, compreende somente aquelas que de algum modo ocupam um “espaço público”,38, sem alcançar diretamente o instituto da exclusão no âmbito das sociedades.

O reconhecimento do conclave de exclusão como deliberação social - ainda que de especial importância - e não procedimento disciplinar ou de julgamento permite esclarecer uma série de aspectos de sua disciplina, bem como afastar analogias e comparações inadequadas. Enquanto deliberação social, o procedimento de exclusão segue todos os princípios e regras gerais previstos no capítulo das sociedades limitadas.

Nessa esteira, retomando o tema da convocação do excluendo, é incabível qualquer paralelo, seja em termos de forma, seja em relação ao conteúdo mínimo, entre esta última e a citação do processo judicial. A convocação do conclave de exclusão é ato típico do Direito Societário e deve simplesmente fornecer informações, claras ainda que sumarizadas, sobre a ordem do dia. Tal ato não se equipara, sequer por analogia, a uma petição inicial e não deve conter detalhadamente todas as alegações e argumentos da sociedade.

\footnotetext{
38 “As associações privadas que exercem função predominante em determinado âmbito econômico e/ou social, mantendo seus associados em relações de dependência econômica e/ou social, integram o que se pode denominar de espaço público, ainda que não-estatal.” e “A União Brasileira de Compositores - UBC, [...], integra a estrutura do ECAD e, portanto assume posição privilegiada para determinar a extensão do gozo e fruição dos direitos autorais de seus associados.” STF, Recurso Extraordinário nº 201.819-8, Rel. do acórdão Exmo. Min. Gilmar Mendes, D.J.U. 27/10/2006.
} 
Não se pode excluir que a sociedade, por zelo e para afastar alegações de nulidade da convocação, vá além das medidas previstas na lei ou no contrato social e informe o excluendo a respeito da realização do respectivo conclave por meio de notificação extrajudicial, com intervenção de oficial do Registro de Títulos e Documentos, ou mesmo através de notificação extrajudicial. Nenhuma de tais providências, contudo, terá o propósito ou a função de uma citação judicial.

No mesmo sentido, não se pode qualificar como "revelia" a eventual ausência do excluendo no conclave de exclusão ${ }^{39}$. O seu não comparecimento implica simplesmente a renúncia ao direito de apresentar suas razões aos consócios, não formando qualquer presunção de veracidade em favor das alegações destes últimos.

O artigo 1.085 não estabelece quorum de instalação específico para o conclave de exclusão, aplicando-se as regras previstas no caput do artigo 1.074, que determina a presença de detentores de três quartos do capital social em primeira convocação e em qualquer número em segunda convocação, ressalvado regime especial estabelecido no contrato social para a reunião de sócios. De qualquer forma, tendo em vista a maioria absoluta necessária à aprovação da deliberação de exclusão, um conclave com quorum inferior à metade do capital social, apurado em segunda convocação, teria pouco significado, servindo apenas para registrar que os sócios ali presentes mostraram-se diligentes e buscaram responder ao inadimplemento de seu consócio.

Como indicado anteriormente, o sócio que se busca excluir naturalmente não vota na respectiva deliberação, porque se trata evidentemente de questão que lhe diz respeito pessoal e diretamente. Desse modo, o excluendo encontra-se em evidente situação de conflito de interesse, nos termos do artigo 1.074, parágrafo $2^{\circ}$, do Código Civil de $2002^{40}$. De qualquer forma, como salienta precisamente Waldecy Lucena, o voto do excluendo é,

\footnotetext{
39 “Não é requisito de validade da exclusão extrajudicial o comparecimento do sócio que se deseja excluir na reunião ou assembléia que deliberar sobre a exclusão, tampouco a apresentação por ele de 'defesa' ou de alegações. Por outro lado, a ausência do sócio indigitado não presume revelia, não se podendo daí deduzir sua confissão ficta de 'culpa'. O sócio ausente tem direito pleno de argüir o mérito da exclusão, tanto quanto o tem o sócio presente.” (grifo no original) in M. CARVALHOSA, Comentários ao Código Civil - Parte Especial do Direito de Empresa, p. 319.

40 “...caso o sócio que se deseja excluir esteja presente ao conclave, não se pode admitir sua participação na votação de exclusão, sob pena de afronta $\S 2^{\circ}$ do art. 1.074 do Código, uma vez que existe aí conflito fundamental de interesses." in M. CARVALHOSA, Comentários ao Código Civil - Parte Especial do Direito de Empresa, p. 319.
} 
por si só, de todo irrelevante para o resultado final da exclusão ${ }^{41}$. Uma vez que o quorum de aprovação da proposta de exclusão é o da maioria absoluta, apurada em relação ao capital social total e não entre os presentes ao conclave, a aprovação da proposta de exclusão exige sempre um número mínimo e fixo de votos. Eventual voto contrário do excluendo não determinaria a rejeição da proposta, enquanto um seu hipotético voto a favor da decisão converteria a exclusão em retirada consensual.

Em relação aos demais quotistas, a regra geral do conflito de interesse deve ser tomada cum granis salis. Em princípio, como discutido anteriormente, os interesses de todos os sócios são de alguma maneira afetados, negativa ou positivamente, pela exclusão de um consócio, tanto que não poderiam jamais exercer a função de árbitro ou juiz em disputa que versasse sobre a matéria. Por outro lado, concluir que todos os sócios estariam impedidos de votar, por força do parágrafo $2^{\circ}$ do artigo 1.074 do Código Civil de 2002, significaria dizer que o artigo 1.085 do mesmo diploma disciplinou uma deliberação impossível, o que não parece razoável.

Parece ser mais correto, portanto, o entendimento segundo o qual os consócios devem ser considerados como impedidos de votar na deliberação de exclusão apenas se direta e pessoalmente envolvidos com os fatos que motivaram a proposta de exclusão. Assim, por exemplo, caso se discuta a exclusão de um sócio-administrador, em razão de operações abusivas realizadas - em nome da sociedade - em favor de um outro sócio, este último estaria impedido de $\operatorname{votar}^{42}$. De qualquer forma, em razão do já mencionado requisito da maioria absoluta, a caracterização de conflito de interesse será, quase sempre, favorável ao próprio excluendo.

\footnotetext{
41 “....se intui da desvalia do excluendo votar ou não a sua exclusão. Se se exige a maioria absoluta do capital social aprobatória da exclusão, sem se abater a parcela de capital subscrita pelo excluendo, como feito pelo Código, não importa se o excluendo vote ou não.” in J. LUCENA, Das Sociedades Limitadas, p. 745-746.

${ }^{42} \mathrm{O}$ Professor Haroldo Verçosa entende que, por uma questão de eqüidade, tanto o excluendo quanto o consócio que denunciou seu inadimplemento poderiam votar na assembléia de exclusão: “...estaria também impedido de votar o denunciante da justa causa, uma vez que a iniciativa em tal sentido pode ter surgido como efeito de algum ato de vingança, por qualquer razão estranha ao funcionamento da sociedade e ao relacionamento entre os sócios. Esta exigência poderia tornar o direito de exclusão uma impossibilidade fática. Daí entender-se que mesmo o sócio a ser excluído ou os sócios denunciantes, se for o caso, podem votar na assembléia em causa, responsabilizando-se, evidentemente, por abuso do direito de voto, caso o tenham proferido no atendimento de interesses meramente pessoais, e não no tocante aos interesses da sociedade.”H. VERÇOSA, Curso de Direito Comercial, vol. 2, p. 537.
} 
Mesmo que não vote, o excluendo tem expressamente do direito de participar dos debates do conclave de exclusão e poderá eventualmente apresentar documentos aos consócios. Trata-se, contudo, de mero convencimento assemblear. O excluendo não pode "produzir provas”, exigir perícia ou convocar testemunhas, pois tais procedimentos são incompatíveis com o pragmatismo e a simplicidade de formas do Direito Societário. Uma tentativa de "processualizar" o conclave de exclusão, além de ser conceitualmente equivocada, resultaria em regime assemblear ineficaz e em processo deficiente.

Os sócios têm o dever de zelar pela presença dos pressupostos legais da deliberação de exclusão não em homenagem ao princípio do devido processo legal, mas em razão da própria responsabilidade, ilimitada e pessoal, pelas decisões tomadas contrariamente à lei ou ao contrato social, nos termos do artigo 1.080 do Código Civil de 2002. É verdade que, na hipótese de exclusão abusiva, o excluendo sofre imediatamente os efeitos da decisão injusta, mas normalmente deverá esperar meses ou anos para ser reintegrado na sociedade e ver-se ressarcido pelos danos devidos. Trata-se, entretanto, de um risco inerente à inversão do ônus do recurso ao Judiciário, conhecido e previamente assumido pelo sócio, tanto que necessariamente refletido em cláusula expressa do contrato social.

Uma vez aprovada, a deliberação de exclusão torna-se ato da própria sociedade e não da maioria social, vinculando todos os sócios, inclusive os ausentes ou os que dela discordaram, nos termos do artigo 1.072, parágrafo $5^{\circ}$ do Código Civil de 2002. Sucessivamente à aprovação da deliberação da exclusão, os sócios devem lavrar a respectiva ata de exclusão e firmar um instrumento separado de alteração do contrato social, para refletir a mudança no quadro de sócios da sociedade. Este instrumento não deve ser firmado por todos os sócios, mas ao menos pelo grupo de quotistas que, conjuntamente, forme a maioria absoluta prevista pelo artigo 1.085. De qualquer modo, o registro se presta a criar uma presunção de conhecimento por parte de terceiros, mas as deliberações tomadas durante o conclave de exclusão produzem efeitos desde logo para os presentes à reunião ou assembléia.

A ata deve indicar, ainda que de forma sumária, os argumentos de cada uma das partes e as razões que motivaram a maioria social a aprovar a exclusão. Não se trata de uma formalidade vazia de sentido. O principal destinatário de tais razões é justamente o juiz togado (ou árbitro) eventualmente instado a apreciar a licitude do procedimento de 
exclusão. Nesse sentido, é particularmente importante para o sócio excluído exigir que a ata contenha indicação de todos os seus argumentos, de forma que os consócios não possam alegar que a exclusão abusiva tenha sido aprovada em boa-fé, pelo desconhecimento dos esclarecimentos prestados pelo quotista expulso.

Uma vez que a deliberação de exclusão comporta uma alteração do contrato social, os quotistas que dela discordarem estarão autorizados a exercer direito de recesso, retirandose da sociedade dentro do prazo de trinta dias a contar da data de realização do conclave, conforme o disposto no artigo 1.077 do Código Civil de 2002.

O sócio excluído, tendo participado do conclave, poderá exigir cópia certificada da respectiva ata, de acordo com o artigo 1.075, parágrafo $3^{\circ}$ do Código Civil de 2002. A despeito de, em rigor, não ter mais a qualidade de sócio ao final do conclave, o excluído presente aos debates participou deles na condição de quotista e tem o direito a receber uma cópia da ata. De posse de tal documento, o excluído poderá buscar imediatamente a tutela judicial de sua situação, sem ter de aguardar o registro da ata pelos demais sócios. Caso o excluído não tenha a intenção de questionar a decisão de exclusão em si, mas almeje simplesmente o pagamento de seus haveres, terá ele legitimidade para, em caso de demora ou omissão dos administradores da sociedade, solicitar diretamente e em nome próprio o arquivamento da ata, nos termos do caput do artigo 1.151.

A reação dos tribunais à exclusão extrajudicial representa um dos aspectos mais críticos para a preservação do sentido do instituto em questão. O juiz deve agir com extrema cautela em relação à concessão de medidas de urgência em favor do excluendo, sobretudo anteriormente à realização da respectiva assembléia ou reunião. O conclave de exclusão apenas deve ser cancelado em situações extraordinárias, em casos de patente e inquestionável ilegalidade, tal como na hipótese em que a causa justificadora da proposta de exclusão seja, em si e em abstrato, contrária à lei. É o caso, por exemplo, da ordem do dia em que se proponha a exclusão do sócio em função de sua recusa em votar a favor de operação ilícita, ou então, por motivos atinentes exclusivamente a uma relação contratual bilateral, mantida com outro sócio, estranha às atividades da sociedade. Em regra, contudo, a tutela judicial deve ser posterior à deliberação. Caso contrário, a exclusão extrajudicial deixará de representar uma inversão do ônus ao recurso ao Judiciário, para se converter em mera dilação burocrática do contencioso perante os tribunais. 
As mesmas críticas podem ser levantadas em relação à anulação do conclave de exclusão por meio da concessão de tutela antecipada. O sentido da exclusão extrajudicial é justamente permitir à sociedade que a apreciação judicial da conduta supostamente lesiva do quotista, em regra uma questão complexa e intrincada, transcorra sem a presença do excluendo no quadro de sócios. Por isso, uma excessiva generosidade dos tribunais em relação ao sócio excluído, em termos de concessão de medidas de urgência, também pode representar uma desnaturação da exclusão extrajudicial. 


\section{ASPECTOS CONTROVERSOS DA EXCLUSÃO DE SÓCIO}

\subsection{A Cláusula de Vedação da Exclusão de Sócio}

Como mencionado anteriormente, em seu notável e extremamente detalhado Projeto de Código Civil, o eminente jurista Teixeira de Freitas incluiu o parágrafo $1^{\circ}$, do artigo 3.058, que considerava expressamente nula, de pleno direito, a cláusula do contrato social que afastasse a possibilidade de exclusão de um sócio em todas e quaisquer hipóteses ${ }^{1}$.

Ocorre que, sucessivamente, o Código Comercial de 1850, o revogado Decreto 3.708/19 bem como o Código Civil de 2002 não estabeleceram qualquer restrição explícita à possibilidade de os sócios, através de cláusula expressa constante do contrato social, estipularem que o remédio da exclusão não seja aplicável em relação à respectiva sociedade. Resta, portanto, espaço para discussão da admissibilidade de uma disposição de tal gênero. De fato, existe na doutrina brasileira contemporânea dúvida quanto à admissibilidade e validade de uma cláusula de tal natureza ${ }^{2}$.

É importante salientar, preliminarmente, que tal querela parece estar circunscrita à exclusão judicial de sócio, disciplinada pelo artigo 1.030 do Código Civil de 2002, sem alcançar a exclusão extrajudicial, prevista pelo artigo 1.085 do mesmo diploma. Com efeito, uma vez que a existência de cláusula expressa no contrato social admitindo a exclusão extrajudicial consiste em requisito essencial para a aplicação do instituto, uma eventual cláusula que vedasse a exclusão sob esta modalidade não seria mais do que um reforço pleonástico (mas de qualquer forma lícito) daquilo que prevê a própria lei. Nem se cogita também afastar por meio de disposição contratual a exclusão de pleno direito,

\footnotetext{
1 “Art. 3.058 - Proíbe-se outrossim estipular, qualquer que seja a espécie de sociedade: $1^{\circ}$ Que qualquer dos sócios não possa renúncia, ou ser excluído, havendo para isso justa causa...” (grifo no original) in A. de FREITAS, Código Civil - Esbôço, vol. 3, p. 929.

${ }^{2}$ Trata-se de tema que também ocupou a doutrina italiana, que ainda não alcançou consenso sobre a matéria: "La soluzione è controversa. A parte l'opinione di chi ritiene ammissibile prevedere che determinate inadempienze non diano luogo ad esclusione, ma soltanto al risarcimento dei danni (magari liquidato convenzionalmente tramite una clausola penale), la dottrina è divisa: a chi ammette addirittura la possibilità di depennare tutte le cause di esclusione - e di bandire perfino l'istituto stesso dell'esclusione - si contrappone chi nega validità ad una clausola siffatta, che violerebbe il principio, sancito dall'art. 2740, secondo il quale la limitazione della responsabilità personale può essere convenuta soltanto nei casi espressamente ammessi dalla legge: la clausola in esame toglierebbe alla società l'unica arma contro gli inadempimenti del socio.” (grifo no original) in V. BUONOCORE, G. CASTELLANO, R. COSTI, Società di Persone, p. 1138.
} 
prevista no parágrafo único do artigo 1.030, que tem natureza cogente e visa a defender o interesse público. Em tal caso, a expulsão se opera pelo simples comando do legislador ${ }^{3}$.

Desse modo, o debate centra-se, exclusivamente, na determinação do caráter, dispositivo ou cogente, da determinação legal que autoriza a exclusão por falta grave, prevista no caput do artigo 1.030 do Código Civil de $2002^{4}$.

O Professor Haroldo Malheiros Duclerc Verçosa entende que a “cláusula de não-exclusão” não pode ser considerada válida porque representaria, em termos práticos, uma proteção ao sócio inadimplente e, em última análise, uma barreira defensiva para condutas ilícitas ${ }^{5}$. Assim, mesmo que não mencionada expressamente pela lei como desejara Teixeira de Freitas, a proibição de tal cláusula emanaria de uma interpretação sistemática das normas que disciplinam a sociedade limitada, representando uma verdadeira exigência lógica do sistema.

Para Waldecy Lucena, por outro lado, a existência de cláusula de vedação da exclusão seria extremamente indesejável e criaria uma série de problemas de ordem prática, mas não seria incompatível com nosso ordenamento - desde que limitada ao inadimplemento não culposo - exatamente em razão da inexistência de proibição expressa a esse respeito ${ }^{6}$. Tal entendimento decorre da idéia de que, enquanto instrumento de natureza contratual, a exclusão facultativa possui caráter eminentemente privado e, portanto, podem os sócios renunciar à aplicação do instituto.

Nesse sentido, na opinião do ilustre estudioso, a cláusula que afastasse de plano a aplicação do remédio da exclusão seria válida e eficaz, de forma que mesmo na hipótese de

\footnotetext{
3 "Deroghe convenzionali in senso restrittivo rispetto alle ipotesi legali sopra esaminate non sono possibili (non sono valide) se riferite alle cause di esclusione di diritto." in V. BUONOCORE, G. CASTELLANO, R. COSTI, Società di Persone, p. 1137.

${ }^{4}$ Cumpre recordar que, em função da remissão expressa contida no artigo 1.085 do Código Civil de 2002, o artigo 1.030 é absorvido como próprio pelo regime das sociedades limitadas, sendo aplicável a tal tipo societário ainda que o contrato social adote como supletiva a disciplina das sociedades anônimas, nos termos do parágrafo único do artigo 1.053.

5 “...pode perquirir-se a respeito da validade de cláusula de não-exclusão inserida no contrato social. Isto implicaria prévia renúncia genérica ou específica ao direito de excluir previsto nas hipóteses legais acima mencionadas. Não se pode concordar com tal cláusula, pois ela opera claramente contra princípios fundamentais do direito societário. Ela somente protegeria o sócio cuja atuação fosse contrária às suas obrigações, o que representa justamente a causa da exclusão." in H. VERÇOSA, Curso de Direito Comercial, vol. 2, p. 155.

${ }^{6}$ J. LUCENA, Das Sociedades Limitadas, p. 727-728.
} 
reiteradas e graves violações dos deveres de colaboração e lealdade por parte de um determinado sócio, a sociedade e os demais quotistas seriam obrigados a recorrer exclusivamente a medidas alternativas - tais como a suspensão judicial do direito de voto, afastamento da administração, ação de reparação de danos, etc. - para mitigar a situação.

Em objeção ao argumento de Lucena, convém recordar a antiga lição de Trajano de Miranda Valverde, segundo a qual o preceito de que são válidas todas as cláusulas contratuais não frontalmente colidentes com normas cogentes deve ser aplicado com extrema prudência no âmbito do Direito Societário ${ }^{7}$. De fato, as normas societárias produzem impactos não apenas entre as partes, mas podem afetar interesses legítimos de terceiros que estabelecem relações com a sociedade. A esse respeito, é certo que os beneficiários diretos do instituto da exclusão facultativa de sócio são a própria sociedade e os quotistas adimplentes, mas a preservação da empresa é tema que interessa também empregados, colaboradores, clientes e credores.

Mais contundente, entretanto, parece ser a objeção de que uma vedação ampla, geral e incondicionada à aplicação do instituto de exclusão representaria uma estrada aberta para a conduta abusiva do sócio. Como já discutido anteriormente (Capítulo 5), nas sociedades limitadas, o adimplemento dos deveres de lealdade representa o contraponto lógico ao direito de manter a condição de sócio ${ }^{8}$. Desse modo, a simples proibição da exclusão do quotista infrator seria tão contrária a este último preceito quanto a exclusão do sócio adimplente sem justa causa.

Por outro lado, não se pode desconsiderar o fato de que a aplicação do remédio da exclusão está sempre, de uma forma ou de outra, condicionada à vontade da maioria social. Mesmo pela via judicial, o procedimento de exclusão está sujeito a prévia deliberação dos sócios, consoante o disposto no caput do artigo 1.030 do Código Civil de 2002. Além disso, é importante recordar que uma sociedade limitada pode ser construída de modo a possuir um regime extremamente próximo ao das sociedades anônimas, cuja disciplina não prevê o instituto da exclusão, mas nem por isso deixa a sociedade à mercê do inadimplemento do

\footnotetext{
7 "A ilicitude de um ato pode simplesmente decorrer de sua incompatibilidade com um sistema ou uma determinada instituição. Assim, em matéria de sociedade, [...], não é exato dizer-se que tudo o que não é proibido é permitido; cada instituição legal tem um mecanismo e uma função própria, e o que desnatura essa função e força êsse mecanismo é ilegal.” in. T VALVERDE, Sociedades por Ações - Comentários ao Decreto-Lei $n^{\circ}$ 2.627, de 26 de Setembro de 1940, p. 59.

${ }^{8}$ Capítulo 5. L. LEÃES, Exclusão Extrajudicial de Sócio em Sociedade por Quotas, p. 89.
} 
sócio. Soa, portanto, exagerado recusar qualquer valor para disposições contratuais ou deliberações dos sócios que restrinjam o exercício de tal direito, se o próprio legislador privilegiou a vontade das partes em tal contexto.

O tema do Direito Societário mais próximo à “cláusula de não-exclusão” é quase certamente a questão da renúncia ao direito de recesso. As principais conclusões desenvolvidas pela doutrina em relação a tal matéria podem, com efeito, ser tranpostas para o debate da exclusão de sócios, ainda que por via analógica, fornecendo importantes subsídios para a construção de uma posição intermediária em relação à cláusula de vedação da expulsão.

Tal como a exclusão, o recesso representa uma hipótese de resolução do contrato de sociedade limitadamente a um sócio. Para evitar a opressão da maioria social e o esvaziamento do sentido do instituto, entende a doutrina majoritária que é inadmissível a renúncia antecipada e "universal” a tal direito ${ }^{9}$. Admite-se, contudo, a renúncia ao direito de recesso em hipóteses concretas, de forma a conferir à sociedade a segurança jurídica necessária para concluir operações importantes - como uma fusão, por exemplo -, sem ter a preocupação de ver-se descapitalizada pela retirada de um minoritário.

Aplicando-se o mesmo princípio ao instituto da exclusão de sócio, poderia se reconhecer como legítimas (i) a cláusula do contrato social que afastasse a possibilidade de expulsão em determinadas hipóteses, restritas e delimitadas, e (ii) a deliberação dos sócios que, diante de uma situação concreta de inadimplemento, isentasse o sócio da incidência de tal medida extrema, em troca do devido ressarcimento do dano causado à sociedade.

Assim, por exemplo, os sócios poderiam reconhecer expressamente que determinada atividade econômica, já exercida por um consócio anteriormente à constituição da sociedade, não representa concorrência desleal a esta última. Ou então, poderiam autorizar um sócio ativamente engajado na administração da sociedade a licenciar-se por um longo período para tratamento médico, sem que isso pudesse justificar sua expulsão.

\footnotetext{
9 “Não pode, no entanto, haver renúncia universal desse direito [recesso] inserida no contrato social. Tal cláusula seria aberrante por ensejar o abuso dos sócios majoritários que poderiam alterar livremente o contrato social em detrimento dos interesses dos sócios minoritários, sem que estes pudessem retirar-se." in M. CARVAlHOSA, Comentários ao Código Civil - Parte Especial do Direito de Empresa, p. 252.
} 
Essa solução intermediária - vedação da renúncia universal e antecipada, aceitação da renúncia à exclusão em casos específicos - vai ao encontro da posição de parte da doutrina italiana $^{10}$ e concederia aos sócios a flexibilidade necessária para lidar com situações sensíveis, sem privar em termos absolutos a sociedade de um importante instrumento de defesa de sua integridade.

\subsection{A Exclusão do Sócio Administrador}

O problema da aplicação do instituto da exclusão em uma situação de sobreposição das qualidades de quotista e administrador divide-se inevitavelmente em duas questões: (i) se o administrador deve ser destituído de seu cargo caso seja excluído do quadro de sócios e (ii) se um sócio deve ser excluído da sociedade na hipótese de destituição da administração, em função da violação de deveres típicos do exercício do cargo de administrador ${ }^{11}$. Em ambos os casos, contudo, o tema de fundo é o mesmo, e diz respeito à correlação entre causas de destituição e e causas de exclusão.

Para Giuseppe Bollino, a perda compulsória do status de sócio é absolutamente incompatível com a manutenção da qualidade de administrador, uma vez que, consumada a exclusão, este último não teria qualquer interesse pessoal no bom resultado da gestão da sociedade $^{12}$. O argumento de Bollino não parece, entretanto, de todo preciso, particularmente quando transposto para o ordenamento brasileiro. Em primeiro lugar, na sociedade limitada brasileira, contrariamente ao que se verifica entre as sociedades de pessoas do ordenamento italiano - principal campo de aplicação da exclusão facultativa e objeto da análise de Bollino -, não existe dúvida quanto à admissibilidade de administradores não sócios. Assim, o fato da perda da qualidade de sócio, como na hipótese de venda da própria participação, por exemplo, não é por si só incompatível com a permanência na administração da sociedade.

É inclusive normal que, em situações de venda do controle de uma sociedade, inclua-se na avença a obrigação do sócio vendedor das quotas de continuar na administração por determinado período, de modo a evitar uma perda de know-how e uma solução de

\footnotetext{
${ }^{10}$ V. BUONOCORE, G. CASTELLANO, R. COSTI, Società di Persone, p. 1138.

${ }^{11}$ G. BOLLINO, Le Cause di Esclusione del Socio nelle Società di Persone e nelle Cooperative, parte II, p. 546.

${ }^{12}$ G. BOLLINO, Le Cause di Esclusione del Socio nelle Società di Persone e nelle Cooperative, parte II, p. 547.
} 
continuidade nas atividades da empresa. Com efeito, na sociedade limitada brasileira, as qualidades de sócio e de administrador situam-se em planos diversos.

No silêncio do contrato social, o quorum de deliberação exigido para a aprovação da destituição de sócio nomeado administrador por força de cláusula do próprio contrato (e não por instrumento em separado) corresponde ao voto afirmativo dos detentores de ao menos dois terços do capital social, consoante o parágrafo $1^{\circ}$ do artigo 1.063 do Código Civil de 2002. Esse fato implica que, em princípio, sócios com participação conjunta superior à metade, mas inferior a dois terços do capital social, terão os votos necessários para (i) aprovar a proposição de ação judicial de exclusão contra o sócio administrador (conforme artigo 1.030, caput) ou (ii) determinar a expulsão extrajudicial deste último (de acordo com o artigo 1.085), mas não poderão destituí-lo imediatamente da administração da sociedade.

A destituição do excluendo do cargo de administrador, em tal hipótese, apenas poderá ocorrer com a consumação da perda do status socii. De fato, enquanto ex-sócio, o administrador poderá ser destituído por meio de deliberação dos sócios detentores de metade do capital social, nos termos do artigo 1.076, inciso II, em combinação com o artigo 1.071, inciso III.

Cumpre reconhecer que, na grande maioria dos casos, a perda compulsória da qualidade de sócio - que, tanto judicial quanto extrajudicialmente, exige uma manifestação da maioria social - romperá os necessários vínculos de confiança entre o administrador ex-sócio e os quotistas remanescentes. Todavia, como indicado anteriormente, a destituição do administrador não decorre automaticamente da deliberação de exclusão. É importante que a deliberação de exclusão trate também deste ponto e, inclusive no caso de exclusão extrajudicial, é lícito que a matéria esteja compreendida na ordem do dia do conclave de expulsão.

Além disso, é possível vislumbrar hipóteses excepcionais em que a exclusão do sócio não seja totalmente incompatível com a manutenção de cargo da administração. Não é de todo inverossímil, por exemplo, a hipótese em que um sócio, em função de contratempos pessoais, não seja capaz de integralizar sua quota, sendo portanto excluído da sociedade 
como remisso, mas mantenha boas relações com seus consócios e, por sua habilidade de gestão, seja mantido no cargo de administrador.

Em relação à segunda questão, ou seja, a exclusão do quotista que tenha sido destituído da administração de uma sociedade por violação de deveres inerentes ao cargo, é necessário analisar a natureza do inadimplemento do sócio-administrador em cada caso concreto.

É importante recordar que a destituição de um administrador é, contrariamente à exclusão, ato discricionário da sociedade. Nesse sentido, o campo de incidência da destituição é naturalmente mais amplo do que o de aplicação do remédio da exclusão, compreendendo situações menos graves, que não autorizariam a imposição da perda da qualidade de sócio, tal como a simples insatisfação com o desempenho profissional do administrador.

Para que, além de motivar a destituição do cargo de administrador, a situação de inadimplemento justifique também a exclusão do sócio, é necessário que esta, concomitantemente, seja grave e corresponda a uma violação expressa (i) do dever de colaboração, como no caso em que a atribuição da qualidade de sócio seja expressamente condicionada pelo contrato social ao exercício do cargo de administrador, ou (ii) do dever de lealdade, na hipótese em que a conduta do sócio administrador represente uma grave violação da cláusula implícita de boa-fé objetiva ${ }^{13}$.

\section{3. $\quad$ Exclusão em Sociedade com Dois Sócios}

Anteriormente à promulgação do Código Civil de 2002, discutiu-se longamente no Brasil a possibilidade de se expulsar um sócio de uma sociedade com apenas dois membros, tendo em vista a unipessoalidade decorrente da admissão da demanda de expulsão. Soares de Faria entendia que a exclusão seria admissível em tal hipótese, mas que inevitavelmente redundaria na dissolução automática, de fato e de direito, da sociedade ${ }^{14}$. Ainda que se consentisse ao sócio remanescente continuar com a atividade na qualidade de comerciante

\footnotetext{
13 “...l'inadempimento dell'amministratore può essere considerato causa di esclusione dalla società non sempre ma solo allorquando tale inadempimento si concretizzi anche in una violazione delle obbligazioni fondamentali a lui facenti capo come socio." in G. BOLLINO, Le Cause di Esclusione del Socio nelle Società di Persone e nelle Cooperative, parte II, p. 553.

14 "Entendemos, no entanto, com Vivante que ainda neste caso [sociedade com apenas dois sócios], é possível a exclusão, sem que o outro socio seja à liquidação e partilha, muito embora fique a sociedade de facto e de direito dissolvida.” in S. FARIA, Da Exclusão de Socios nas Sociedades de Responsabilidade Illimitada, p. 21.
} 
individual, essa alternativa implicava evidente dano para o andamento dos negócios. Para a doutrina da época, a única hipótese de sobrevivência da sociedade seria em si a cessão de uma quota a um terceiro, simultaneamente ao processamento da exclusão ${ }^{15}$.

O tema também foi enfrentado em Direito Comparado. De acordo com Arturo Dalmartello, o Código das Obrigações Suíço de 1911, foi a primeira legislação a reconhecer expressamente ao único sócio remanescente o direito de continuar com as atividades da sociedade após a exclusão de seu consócio ${ }^{16}$. Em um período em que a legislação italiana não tolerava a sociedade unipessoal, Dalmartello entendia que a única conciliação possível entre o princípio da preservação da empresa e a exclusão do segundo sócio seria, em linha com a posição de Soares de Faria, a transformação da empresa coletiva em empresa individual. Ou seja, a sociedade seria dissolvida, mas o sócio inocente seria autorizado a continuar a exercer a atividade em nome próprio ${ }^{17}$.

A questão gradualmente perdeu importância em relação à aplicação do instituto da exclusão de sócios, na medida em que os diferentes ordenamentos passaram a aceitar a ausência de pluralidade de sócios, ao menos em caráter temporário, sem que esta determinasse a dissolução da sociedade. No Brasil, após a promulgação da Lei nº 6.404/76, sempre por via do artigo 18 do Decreto 3.708/19, nossos tribunais passaram a admitir a exclusão do segundo sócio, determinando simplesmente que a pluralidade de sócios, fosse reconstituída até o exercício social seguinte, nos termos do artigo 206, inciso I, alínea “d”, da referida norma ${ }^{18}$.

A este respeito, é lamentável que a sociedade unipessoal não tenha sido plenamente admitida na mais recente reforma da legislação societária brasileira. Com efeito, dentre as grandes “oportunidades perdidas” com a promulgação do Código Civil de 2002, pode-se

\footnotetext{
${ }^{15}$ S. FARIA, Da Exclusão de Socios nas Sociedades de Responsabilidade Illimitada, p. 21-22.

${ }^{16}$ A. DALMARTELLO, L'Esclusione dei Soci dalle Società Commerciali, p. 32.

17 “...conservare la impresa gerita dalla società nei casi in cui è assolutamente impossibile salvare la società come tale.” (grifo no original) in L'Esclusione dei Soci nelle Società Commerciali, p. 31.

18 "É de ver, pois, o Dr. Juiz bem aplicou a Lei, ao dissolver, parcialmente, a sociedade, dando oportunidade ao cotista remanescente para dentro do prazo de um ano, admitir novo cotista, sob pena da dissolução de pleno direito, e tal entendimento não discrepa da orientação firmada na moderna doutrina e no direito pretoriano.” e ainda “A ‘dissolução parcial da sociedade', na qual se garante ao sócio remanescente, quando constituída por apenas dois sócios, recompor a empresa com admissão de outro sócio cotista e ou ainda que como firma individual, [...] compatibiliza-se, em verdade, com o interesse social.” in STJ, Recurso Especial nº 387-MG, Rel. Exmo. Min. Waldemar Zveiter, DJU 19/02/90.
} 
certamente incluir a não admissão da constituição e existência, em caráter estável, regular e permanente, das sociedades unipessoais ${ }^{19}$.

Os autores do anteprojeto efetivamente afirmaram em diversas ocasiões terem evitado a adoção de "modismos” ou a incorporação ao novo diploma de conceitos e princípios não claramente consolidados na doutrina ou na jurisprudência. Especificamente em matéria de sociedade unipessoal, entretanto, tal conservadorismo não parece justificável e, apesar de todos os comentários em sentido contrário, reflete provavelmente o caráter obsoleto do anteprojeto que resultou no Código Civil de 2002, que já contava quase trinta anos de existência quando da promulgação deste último (Capítulo 4).

De fato, no período compreendido entre a apresentação do Projeto de Lei do Executivo ${ }^{\circ}$ 634/75 e a efetiva promulgação da Lei Federal n 10.406/02, a doutrina brasileira em favor da aceitação das sociedades unipessoais avançou a passos largos, com a publicação de obras clássicas, com destaque, sobretudo, para a monografia do Professor Calixto Salomão Filho $^{20}$. Além disso, ainda no período inicial de discussão do anteprojeto de Código Civil, a Lei $n^{0}$ 6.404/76, mesmo não admitindo a unipessoalidade como regra geral para a sociedades por ações, já havia disciplinado a constituição das subsidiárias integrais e tutelado a unipessoalidade superveniente e temporária, respectivamente nos termos dos artigos 251 e 206, inciso I, alínea “d”.

A ampla aceitação da sociedade unipessoal no Direito Comparado também contribui para um juízo negativo da opção legislativa adotada no Brasil, nesta matéria. Com efeito, a sociedade limitada com um único sócio é expressamente admitida na Alemanha ${ }^{21}$ e também na Itáliaa ${ }^{22}$. Nesta última jurisdição em particular, a exclusão de um sócio na sociedade de pessoas com apenas dois quotistas é expressamente tratada pelo artigo 2.287, parágrafo $3^{\circ}$, do Código Civil de 1942, que confirma a admissibilidade da expulsão do

\footnotetext{
19 “O novo Código deixa passar em branco a possibilidade de introdução da sociedade limitada unipessoal em descompasso flagrante com as leis modernas, sem explicar o porquê da postura rançosa.” V. FRANCO, $O$ Triste Fim das Sociedades Limitadas no Novo Código Civil, p. 84.

20 "Se fosse necessário hoje descrever a situação do sistema brasileiro, deveria ser dito que não existe o reconhecimento legislativo de qualquer forma de limitação da responsabilidade do comerciante individual. O que existe é apenas uma forma de limitação de responsabilidade - a subsidiária integral - idealizada para os grupos, que não atende aos interesses da pequena empresa individual...” in C. SALOMÃO FILHO, A Sociedade Unipessoal, p. 44.

${ }^{21}$ B. GRUNEWALD, Gesellschaftsrecht, p. 318.

${ }^{22}$ Artigos 2.250, 2.362, 2.475 bis, 2.476, 2.490 bis, 2.497 do Código Civil Italiano.
} 
segundo quotista, mas determina que o procedimento deve, excepcionalmente, ocorrer de forma judicial (ao contrário dos demais casos nos quais, como regra geral, a exclusão se processa de forma extrajudicial) ${ }^{23}$. Não se tem notícia de que a admissão da sociedade unipessoal em tais jurisdições tenha ensejado uma enxurrada de fraudes a credores ou ao abuso sistemático das estruturas societárias.

O principal resultado prático da opção do legislador brasileiro de refutar a sociedade unipessoal foi a proliferação de sociedades unipessoais de fato, nas quais o segundo sócio possui uma participação absolutamente irrelevante, destinada exclusivamente a satisfazer o requisito legal da pluralidade de quotistas, sendo pouco mais do que um "presta-nome”. Tal atitude fere o caráter indutivo e pragmático do Direito Comercial, ao sujeitar as necessidades práticas da atividade econômica a restrições e obstáculos derivados dos cânones clássicos aceitos pela doutrina, enquanto deveria ocorrer precisamente o contrário.

De qualquer modo, é necessário reconhecer que o Código Civil de 2002 ao menos disciplinou de modo claro e preciso as conseqüências da unipessoalidade superveniente. Com efeito, o inciso IV do artigo 1.033 estabelece que a unipessoalidade acarreta a dissolução da sociedade apenas na hipótese em que a pluralidade de sócios não seja recomposta dentro de um período de cento e oitenta dias.

Por força de uma referência direta do artigo 1.087 do Código Civil de 2002 ao artigo 1.044, relativo às sociedades em nome coletivo, o qual por sua vez evoca expressamente o artigo 1.033, atinente em princípio às sociedades simples, a norma em questão aplica-se a todas as sociedades limitadas. De fato, em função dessa cadeia de expressas referências normativas, pode-se concluir que o artigo 1.033 e seu inciso IV aplicam mesmo às sociedades limitadas que, nos termos da faculdade prevista no artigo 1.053, parágrafo único, adotem o regime das sociedades anônimas como disciplina supletiva. Nesse caso, não havendo uma lacuna normativa a ser suprida (especificamente em relação à questão da unipessoalidade), afasta-se a possibilidade da aplicação, salvo se por eventual via analógica, do artigo 206, inciso I, alínea “d”, da Lei nº 6.404/76 às sociedades limitadas.

\footnotetext{
23 “Il legislatore ha preso in esame nell'art. 2287, $3^{\circ}$ co., c.c., l'ipotesi di una società di persone composta da due soli soci di cui uno voglia escludere l'altro. In questo caso, vista l'esigua entità della compagine sociale, formata solo da due individui, non è possibile, come si è visto nel paragrafo precedente, che venga deliberata a maggioranza l'esclusione del socio, anzi si verrebbe a creare una situazione di paralisi dello strumento societario con i due soci l'un contro l'altro armati." in B. ACQUAS, C. LECIS, L'Esclusione del Socio nelle Società di Persone, p. 164.
} 
A interpretação a contrario sensu do artigo 1.033, inciso IV, é relativamente clara. O legislador de 2002 permitiu que a sociedade limitada seja integrada por um único sócio, por um período de até cento e oitenta dias, sem fazer qualquer distinção ou ressalva sobre o modo (por exemplo, venda de quotas, morte do sócio, demissão, recesso ou ainda exclusão) como a pluralidade de sócios foi perdida.

Nesse sentido, não há mais espaço para se argumentar, como se fez no passado, que a exclusão de sócio é inviável nas sociedades limitadas formadas por apenas dois sócios, sob o pretexto de que o resultado prático seria a unipessoalidade. A exclusão é possível em tal caso e não implica a dissolução obrigatória da sociedade.

Uma questão particularmente delicada é a hipótese em que ambos os sócios possuam participações simétricas, cada um deles detendo precisamente a metade do capital social. Tal hipótese se assemelha ao caso da exclusão do sócio majoritário, discutido a seguir, na medida em que nenhum dos sócios poderá formar a maioria qualificada exigida pelo artigo 1.085 do Código Civil de 2002. Como conseqüência, em tal cenário, a exclusão deverá ocorrer forçosamente pela via judicial.

Por fim, convém recordar que o instituto da exclusão de sócio, tal qual disciplinado pelo Código Civil de 2002, busca primordialmente defender o interesse dos sócios e possui traços prevalentemente privatísticos. Assim, como já discutido anteriormente, a sociedade é a titular do direito de exclusão, mas a aplicação de tal solução extrema exige sempre uma deliberação dos sócios. Nesse sentido, é absolutamente incabível e ilógico discutir a exclusão facultativa do sócio único de uma sociedade temporariamente unipessoal, por iniciativa de administradores, empregados, credores ou de quem quer que seja.

É possível imaginar, por outro lado, a hipótese em que uma sociedade limitada tenha temporariamente apenas um sócio - por período inferior a cento e oitenta dias, valendo-se da prerrogativa consignada pelo artigo 1.033, inciso IV, do Código Civil de 2002 - e que tal único quotista seja declarado falido. Nos termos do parágrafo único do artigo 1.030 do próprio Código, tal sócio estaria teoricamente sujeito à imediata exclusão de pleno direito. Ocorre que, no Direito Societário contemporâneo, não se cogita da existência de sociedade 
sem sócios, senão como mero exercício de reflexão ${ }^{24}$. Em tal hipótese extrema, as únicas possibilidades à disposição do juízo responsável pela falência seriam a alienação da sociedade ou a sua dissolução strictu sensu (“dissolução total”), transferindo-se para a massa falida o respectivo produto da venda ou saldo positivo da liquidação.

\subsection{A Exclusão do Sócio Majoritário}

Em linha geral, o sócio majoritário tende a ser aquele cujos interesses estão mais estreitamente alinhados com o da própria sociedade. De fato, tal quotista quase sempre é aquele que assume o maior risco patrimonial (em termos absolutos e não relativos) em relação ao empreendimento comum. Além disso, salvo hipóteses excepcionais de controle minoritário, o sócio com maior participação na sociedade normalmente exerce a influência mais direta sobre a administração desta última, imprimindo o rumo que julga mais adequado aos negócios sociais.

De qualquer modo, os interesses do sócio controlador e da sociedade não são perfeitamente coincidentes. Não é raro que os planos do sócio majoritário - ou dos sócios que, conjuntamente, formem um bloco de controle - venham a colidir com o melhor interesse da sociedade. Com efeito, o tema do abuso de controle é uma das questões perenemente enfrentadas pelo Direito Societário. Basta pensar na hipótese em que o sócio majoritário utilize sua influência sobre a administração da sociedade para adquirir, em termos mais gravosos do que os disponíveis no mercado (ou seja, condições não “estritamente comutativas”25), bens ou serviços de uma outra sociedade da qual seja também o controlador (e na qual possua participação proporcionalmente superior àquela detida na sociedade adquirente). Nesse sentido, não resta dúvida de que o sócio majoritário, como qualquer outro, pode incorrer em grave violação de seus deveres de lealdade e colaboração em face da sociedade.

Ocorre, contudo, que o instituto da exclusão de sócio, conforme disciplinado pelo Código Civil de 2002, foi em grande parte concebido sob a premissa de que o sócio inadimplente a ser expulso não detenha, individualmente, mais da metade do capital social. Em relação à exclusão extrajudicial, em particular, o próprio título da Seção VII, do capítulo do Código

${ }^{24}$ C. SALOMÃO FILHO, O Novo Direito Societário, p. 48.

${ }^{25}$ STJ, Recurso Especial no 798.264-SP, Rel. Exmo. Carlos Alberto Menezes Direito (voto vencido), DJU $16 / 04 / 2007$. 
Civil de 2002 dedicado às sociedades limitadas - "Da resolução da sociedade em relação a sócios minoritários” -, já indica que o instituto foi pensado para ser aplicado a sócios minoritários, fato confirmado pela inequívoca exigência de maioria qualificada (“...maioria dos sócios, representativa de mais da metade do capital social...”) para a aprovação, em reunião ou assembléia, da proposta de exclusão.

Desse modo, a única via aberta para a exclusão do sócio majoritário é a judicial, nos termos do artigo $1.030^{26}$. Em tal hipótese, também é necessária uma prévia deliberação dos sócios para autorizar e instruir os administradores da sociedade a moverem a competente ação contra o sócio excluendo. Todavia, contrariamente ao artigo 1.085 do Código Civil de 2002, o caput do artigo 1.030 do mesmo diploma prevê expressamente que, em tal caso, a maioria deve ser apurada entre os demais sócios. Ou seja, desconsiderando-se a participação do sócio cuja expulsão se busca efetivar.

Tal regra não faz mais do que reiterar o fato de que, por uma questão de conflito de interesse direto e evidente, nos termos do artigo 1.074, parágrafo $2^{\circ}$, o sócio não deve votar na deliberação que trata de sua própria expulsão, como discutido no capítulo anterior. A diferença mais relevante em relação à exclusão extrajudicial reside, contudo, no fato de que o artigo 1.030 não faz nenhuma referência a maioria qualificada, que deva ser apurada em relação ao capital social total. Como conseqüência, o quorum de aprovação de tal deliberação é remetido à maioria simples dos presentes, em conformidade ao artigo 1.076, inciso $\mathrm{III}^{27}$.

Isso significa que os sócios minoritários podem, em princípio, aprovar tal deliberação, mas não quer dizer de forma alguma que se trate de um procedimento simples ou corriqueiro. Com efeito, os obstáculos a tal procedimento são tantos e de tal forma relevantes, sobretudo no caso em que os minoritários não tenham um próprio representante na administração da sociedade, que a exclusão do sócio majoritário deve ser reputada como uma opção extrema, admissível apenas em situações efetivamente extraordinárias.

\footnotetext{
${ }^{26}$ J. BORBA, Direito Societário, p. 94-95. A. GONÇALVES NETO, Lições de Direito Societário, p. 304.

${ }^{27} \mathrm{O}$ texto literal do caput do artigo 1.030 do Código Civil de 2002 dá a entender que se trata de uma maioria apurada por cabeça, ou seja, pelo número total de sócios, sem consideração das respectivas participações no capital social. Trata-se, entretanto, de tese é absolutamente incompatível com a estrutura e características gerais das sociedades contemporâneas, sobretudo a sociedade limitada, que compartilha características com as sociedades de capitais. Deve, portanto, prevalecer o princípio da maioria apurada em relação ao capital social, consoante o caput do artigo 1.010 do Código Civil de 2002.
} 
A primeira barreira a ser enfrentada pelos minoritários será a convocação da respectiva assembléia ou reunião ${ }^{28}$, uma vez que se presume que o majoritário terá uma influência direta mais intensa sobre os administradores da sociedade. Caso estes últimos permaneçam inertes em relação ao pedido de convocação formulado, por prazo superior a oito dias, os minoritários poderão convocar diretamente o conclave, consoante o artigo 1.073, inciso I. O segundo aspecto no qual se podem vislumbrar empecilhos à consumação da exclusão é a eventual resistência dos administradores, leais ao majoritário, em acatar tal deliberação e efetivamente promover a ação judicial contra o sócio controlador.

Além das dificuldades atinentes ao procedimento de exclusão em si, é provavelmente mais importante considerar o efeito que a exclusão de sócio majoritário pode ter sobre as próprias chances de sobrevivência econômica da sociedade. Toda a organização empresarial deve idealmente otimizar os recursos disponíveis e não é normal, nem tampouco eficiente, que uma sociedade disponha de enorme liquidez ou grandes excedentes patrimoniais. Nesse sentido, é difícil pensar que a apuração e pagamento dos haveres de sócio detentor de mais da metade do capital social não tenha um enorme impacto sobre a integridade patrimonial da sociedade.

Salvo situações excepcionais, como o da prestadora de serviços que possua baixo ativo imobilizado ou da sociedade que tenha um elevado crédito líquido contra o excluendo a ser compensado, a liquidação da participação do majoritário exigirá o aporte de novos recursos na sociedade, sob pena de provocar-lhe uma verdadeira amputação financeira.

\subsection{Exclusão de Sócio na Sociedade em Liquidação}

Nos capítulos anteriores, discutiu-se a íntima relação - seja sob a perspectiva histórica, seja sob um ponto de vista conceitual - entre a defesa da atividade empresarial (ou "negocial”) e o instituto da exclusão de sócios. Tal vínculo estreito impeliu alguns doutrinadores italianos a argumentar que a exclusão não teria qualquer sentido e, portanto, não seria cabível após a dissolução da sociedade. De acordo com tal linha de pensamento, tendo a exclusão de sócios o objetivo precípuo de preservar a sociedade e sua atividade econômica,

${ }^{28}$ Nem se cogita que tal decisão possa ser tomada por instrumento escrito, nos termos do artigo 1.072, parágrafo $3^{\circ}$, porque seria necessária, senão a concordância do majoritário, ao menos a sua assinatura do respectivo documento. 
não se poderia cogitar da aplicação do instituto em questão às vésperas da supressão de ambas (sociedade e atividade) ${ }^{29}$. Esta visão chegou inclusive a ser defendida pela jurisprudência das cortes superiores daquele país ${ }^{30}$.

Ao transpor tal discussão para o ordenamento brasileiro, é necessário preliminarmente recordar que a terminologia aplicável ao processo de dissolução e liquidação das sociedades, e a cada uma de suas fases, foi objeto de longo e aceso debate doutrinário no país $^{31}$. Além disso, o uso de tais expressões, cujo significado por si só não é unívoco, tornou-se particularmente confuso e instável no Brasil em função da adoção e ampla difusão da teoria da "dissolução parcial”32.

Por isso, convém, ainda que perfunctoriamente, esclarecer o sentido atribuído aos principais termos empregados neste capítulo. Assim, seguindo a doutrina que parece ser mais atualizada e amplamente aceita ${ }^{33}$, entende-se como “dissolução latu sensu” o conjunto dos procedimentos destinados ao encerramento da sociedade, que se desdobram essencialmente em: (i) “dissolução” (strictu sensu), a deliberação dos sócios ou decisão judicial que determina uma transmutação do objetivo da sociedade, o qual deixa de ser a realização de determinada atividade econômica para limitar-se à ultimação dos negócios em curso; (ii) "liquidação”, a fase ou período que se inicia com a dissolução strictu sensu e precede a extinção, durante a qual a sociedade conversa sua personalidade e capacidade jurídicas, mas se concentra exclusivamente no encerramento de suas atividades, e (iii) “extinção”, o ato conclusivo da dissolução latu sensu que implica o fim da personalidade jurídica e a supressão da sociedade como centro de imputação de direitos e obrigações.

Em termos práticos, a dissolução strictu sensu, a liquidação e a extinção são frequentemente concentradas, tanto em termos temporais quanto de documentação, em um

\footnotetext{
${ }^{29}$ B. ACQUAS, C. LECIS, L'Esclusione del Socio nelle Società di Persone, p. 87.

30 "Dopo la deliberazione di scioglimento di una società di persone, pure se non abbiano ancora avuto inizio le operazioni di liquidazione (per ostacoli di fatto o di diritto, come la pendenza di accertamento giudiziale sull'esistenza della causa di scioglimento), resta preclusa la possibilità per gli amministratori di esercitare poteri diversi da quelli previsti dall'art. 2274 c.c., nonché di procedere all'esclusione di un socio, atteso che la configurabilità di uno scioglimento del rapporto sociale limitatamente ad un socio, con liquidazione della relativa quota, trova ostacolo nel passaggio della società in una fase alla liquidazione di tutti i soci, con la ripartizione del residuo attivo, dopo l'estinzione dei debiti.” Cassazione Civile, Sezione I, n. 3982, 25/06/1980.

${ }^{31}$ M. PENTEADO, Dissolução e Liquidação de Sociedades, p. 19.

32 J. LUCENA, Das Sociedades Limitadas, p. 936.

${ }^{33}$ M. PENTEADO, Dissolução e Liquidação de Sociedades, p. 16-17 e 20.
} 
único ato. Tal situação se verifica porque é muito comum que a sociedade já tenha, de fato, encerrado suas atividades no momento em que os sócios decidam tomar os primeiros passos para a sua dissolução.

Todavia, existem hipóteses em que o volume, a natureza ou a complexidade da atividade desenvolvida pela sociedade no momento imediatamente anterior à dissolução exigem que a fase de liquidação se prolongue por um substancial intervalo de tempo. É exatamente em tais situações que a questão da admissibilidade da exclusão de sócios, após a dissolução strictu sensu, torna-se relevante. A longa duração da fase de liquidação amplia a possibilidade de se verificarem condutas abusivas ou danosas por parte do sócio, mesmo que subseqüentes à dissolução da sociedade.

Como discutido anteriormente, o “fim comum” exerce um papel estrutural em relação à existência e à forma do contrato plurilateral ou associativo e, por conseguinte, sobre a exclusão de sócios. Desse modo, tendo em vista o impacto da dissolução strictu sensu sobre o objetivo da sociedade, o argumento contrário à admissão da exclusão na vigência da liquidação pode efetivamente soar razoável, tanto sob uma perspectiva pragmática, quanto sob uma ótica dogmática.

Entretanto, cumpre recordar que a dissolução não significa uma supressão absoluta e imediata do fim comum, mas meramente sua limitação e transmutação. Na fluência da fase de liquidação, a sociedade preserva sua personalidade jurídica e capacidade de contratar. A atividade econômica anteriormente desenvolvida é simplesmente substituída pelo objetivo de ultimar os negócios sociais da forma mais vantajosa possível para os sócios, em respeito aos direitos dos credores. Mas, isso não significa que a sociedade deixe de existir ou não se oriente por um (novo) fim comum.

Este outro escopo, a despeito de sua natureza expressamente transitória, pode ser prejudicado pela conduta ou omissão dos sócios de diversas maneiras (por exemplo, fraude contábil, apropriação de bens da sociedade, etc.) e merece ser protegido com todos os instrumentos legais disponíveis, incluindo o instituto da exclusão. Não há razão para, no estado de liquidação, exonerar os sócios de seus deveres de lealdade e colaboração. Efetivamente, mesmo no estado de liquidação, ainda se pode identificar a existência, de um 
lado, de um objetivo e de uma atividade a serem resguardados e, do outro, da sociedade, como ente apto e legitimado a defender os próprios interesses e direitos.

Naturalmente, uma vez que as situações tuteladas (fluência normal da atividade e estado de liquidação) possuem natureza distinta, os respectivos motivos para a admissão da exclusão de sócio, em ou em outro caso, tendem a diferir. A mudança do objetivo social determinada pela dissolução da sociedade, importa também uma leitura diversa dos deveres de lealdade e colaboração dos sócios. Assim, por exemplo, perturbar as relações da sociedade com um importante fornecedor pode perfeitamente representar, fora do estado de liquidação, uma causa legítima para a exclusão de um quotista, mas não o será em relação a uma sociedade em liquidação, que não tenha mais nenhuma ambição ou perspectiva real de repor seus estoques com aquele produto específico. A apropriação indevida de fundos da sociedade, em confronto, representará sempre um grave ato contra sociedade, encontrese ela ou não na fase de liquidação.

Ademais, não se pode desconsiderar a possibilidade de reversão da dissolução. Como expressamente indicado pelo artigo 1.071, inciso VI, do Código Civil de 2002, os sócios podem perfeitamente - desde que não verificada a extinção da sociedade e caso estejam presentes os necessários pressupostos econômicos - deliberar a cessação do estado de dissolução, encerrando a liquidação e determinando o retorno da sociedade às suas atividades normais. Esse fato demonstra ulteriormente a sobrevivência da sociedade, enquanto centro de imputação de direitos e obrigações, durante a fase de liquidação, e reafirma a necessidade de tutelar seus interesses, não apenas em nome da mais eficaz ultimação dos negócios pendentes, mas também em função da perspectiva de eventual retomada de suas atividades.

Esses argumentos compeliram a doutrina italiana a assumir uma posição veementemente crítica em relação ao entendimento jurisprudencial contrário à admissão da exclusão por causas verificadas posteriormente à dissolução da sociedade ${ }^{34}$. Como resultado, verifica-se uma nítida tendência de revisão da orientação jurisprudencial anteriormente

\footnotetext{
${ }^{34}$ B. ACQUAS, C. LECIS, L'Esclusione del Socio nelle Società di Persone, p. 90-92.
} 
predominante $^{35}$. Na realidade brasileira, também não se vislumbra motivo para recusar a exclusão de um sócio após a dissolução strictu sensu de uma sociedade.

${ }^{35}$ Em decisão posterior à mencionada anteriormente, a Corte di Cassazione argumentou o seguinte para autorizar a exclusão de um sócio, em sociedade em comandita simples já em fase de liquidação: "La società rileva, sul piano giuridico (non solo come contratto, ma) come forma di organizzazione di una attività economica da svolgere nei confronti di altri soggetti. Questo spiega perché il suo scioglimento non faccia venir meno la forza vincolante dell'atto dal quale ha avuto origine, ma segni l'inizio di una nuova fase (la liquidazione), destinata a definire i molteplici rapporti derivati dall'esercizio dell'attività programmata e a ripartire l'eventuale residuo tra i soci. Invero, il verificarsi di un fatto che determina lo scioglimento della società non comporta la cessazione dell'autonomia patrimoniale, che anzi si rafforza (artt. 2271, 2280 c.c.), non libera i soci dall’obbligo di effettuare i conferimenti (art. 2280, secondo comma, c.c.), né infine determina la dissoluzione dell'organizzazione sociale, poiché anche in tale fase è individuabile una ripartizione di organi e di competenze finalizzata al raggiungimento di una finalità di comune interesse (la definizione delle passività sociali) che la legge considera necessariamente collegata alla gestione delle società (art. 2280 c.c.).” Cassazione civile, sez. I, n 6410, 15/07/1986. 


\section{EFEITOS DA EXCLUSÃO DE SÓCIO}

\subsection{O Momento da Exclusão}

A exclusão do sócio tem como principal e óbvio efeito a perda do status socii. Com a consumação de tal procedimento, resolve-se o complexo feixe de obrigações existentes entre o sócio e a sociedade. O ex-sócio não poderá mais interferir nas decisões da sociedade, participar de reuniões ou exigir informações sobre o andamento dos negócios sociais. O excluído torna-se simplesmente credor quirografário dos seus haveres e devedor da reparação de eventuais danos causados à sociedade.

A exclusão também marca o desligamento do excluído do risco empresarial inerente às atividades da sociedade que o expulsou. Por isso, em princípio, o montante a que faz jus a título de haveres não oscilará, nem positiva nem negativamente, em função de eventos, ganhos ou perdas posteriores à data de exclusão. Para todos os efeitos de cálculo e apuração do montante eventualmente devido ao sócio, deve ser tomada em consideração a situação econômica e comercial da sociedade na data de exclusão. O próprio caput do artigo 1.031 do Código Civil de 2002 refere-se à situação patrimonial da sociedade na data de resolução do vínculo com o sócio. Daí a importância de se determinar com precisão a data em que o excluído deixou de ser sócio.

Na exclusão extrajudicial, poderia haver dúvida entre a adoção da data de realização da assembléia ou reunião de exclusão e o momento de registro da respectiva ata e instrumento de alteração do contrato social. As decisões tomadas durante o conclave produzem efeitos imediatos em relação aos sócios (e administradores) que nele tomaram parte ${ }^{1}$, tenham ou não concordado com tais deliberações. O registro do ato serve à criação da presunção de conhecimento erga omnes de seu conteúdo, mas não é um requisito à sua validade interpartes. Um sócio-administrador presente ao conclave de exclusão não pode, por exemplo, posteriormente à reunião ou assembléia, fornecer ao quotista excluído informações acerca

\footnotetext{
1 “A partir do momento em que deliberada a exclusão, já se disse, perde o excluendo seu status socii, ou seja, antes mesmo do arquivamento do instrumento de alteração contratual decorrente da exclusão. É que a deliberação, entre os sócios, produz efeitos imediatos. O registro é necessário para produzir efeito em face de terceiros e para que se efetive o pagamento dos haveres do excluído.” in J. LUCENA, Das Sociedades Limitadas, p. 749. No mesmo sentido: "Imediatamente após a deliberação da exclusão e a respectiva cientificação ao interessado, considerar-se-á excluído o sócio, ficando afastado de todas as funções que porventura exerça na sociedade, passando a ser um terceiro em relação a ela.” in M. CARVALHOSA, Comentários ao Código Civil - Parte Especial do Direito de Empresa, p. 320.
} 
das atividades da sociedade que sejam tipicamente reservadas aos sócios. Se presente ao conclave de exclusão, ou assim que notificado de tal deliberação, não poderá tampouco o excluído apresentar-se a terceiros como sócio da sociedade ${ }^{2}$.

Todavia, não se pode desconsiderar o fato de que a necessidade de pagamento dos haveres do sócio excluído possui um impacto sobre a integridade patrimonial da sociedade e, portanto, pode afetar severamente os interesses de terceiros de boa-fé. Apenas o registro da ata e da alteração do contrato social nos órgãos competentes ${ }^{3}$ é capaz de criar uma presunção de conhecimento público a respeito da exclusão do sócio.

O artigo 1.151 do Código Civil reproduziu preceito - dedutível por interpretação contrario sensu de seu parágrafo $2^{\circ}$ - já presente no artigo 36 da Lei Federal no 8.934/94, segundo o qual os efeitos do registro retroagem à própria data do ato, mas desde que este último seja apresentado para arquivamento dentro do prazo limite de trinta dias a contar da realização do conclave. Extrapolado tal limite, o registro produz efeitos apenas a partir da respectiva data de deferimento do arquivamento.

No caso de inércia em relação ao cumprimento das formalidades de registro, terceiros poderiam contratar com a sociedade sob a falsa premissa de que esta possui um determinado quadro de sócios e, sobretudo, uma certa situação patrimonial que não mais correspondem à realidade.

Nesse sentido, especificamente no que tange a apuração de haveres e sem prejuízo à eficácia imediata da deliberação em questão em relação aos presentes ao conclave de exclusão, parece mais adequado tomar-se como data de referência o momento de registro do ato de exclusão. Este último marco temporal apenas não será coincidente com a própria deliberação de exclusão, quando for superado o prazo máximo de trinta dias para apresentação do ato à autoridade competente, requisito essencial para a concessão da eficácia retroativa do registro.

\footnotetext{
2 “A exclusão opera seus efeitos a partir da deliberação que a proclame. A eficácia desta é, pois, imediata. Em relação ao sócio excluído, os respectivos efeitos somente começaram a fluir - dado o respectivo caráter receptivo - com base na ciência da alteração processada e, relativamente a terceiros, a contar do arquivamento a ser realizado perante a Junta Comercial.” in P. FONSECA, Dissolução Parcial, Retirada e Exclusão de Sócio, p. 50.

${ }^{3}$ Junta Comercial no caso da sociedade empresária, Registro Civil de Pessoas Jurídicas em relação à sociedade simples constituída sob a forma de sociedade limitada.
} 
O principal problema da adoção da data de registro como referência para a apuração de haveres diz respeito à eventual inércia dos administradores e dos sócios remanescentes em relação ao arquivamento da ata de exclusão, o que pode comportar danos ao sócio excluído. É possível que a sociedade sofra prejuízos no intervalo entre a realização do conclave de exclusão e o tardio registro dos respectivos atos. Durante tal período, o excluído já não será mais sócio e não poderá interferir nos rumos da gestão da sociedade, fato que implica evidente injustiça.

Ocorre recordar, a esse respeito, como já aventado no capítulo anterior, que se o excluído tomou parte do conclave de exclusão, poderá exigir uma cópia certificada da respectiva ata - conforme o artigo 1.075, parágrafo $3^{\circ}$ do Código Civil de 2002 - e, ante a imobilidade da própria sociedade, estará autorizado a solicitar diretamente o registro de tal documento, nos termos do caput do artigo 1.151 do próprio Código.

Por outro lado, se não tiver comparecido ao conclave, o excluído terá de recorrer ao Judiciário para compelir seus ex-consócios a registrar os documentos que formalizam a expulsão ou obter do juiz uma declaração substitutiva de tal medida - desde que, evidentemente, não opte por combater a decisão de exclusão em si.

A despeito de tais dificuldades, parece mais razoável fazer prevalecer o momento de efetivo registro da ata, para fins de apuração dos haveres do excluído, do que assegurar a tal deliberação uma retroatividade dos efeitos do registro superior àquela - já generosa - de trinta dias, prevista expressamente pela lei. Essa é a alternativa que melhor resguarda os interesses dos credores da sociedade e de quaisquer terceiros de boa-fé que decidem com ela negociar. Além disso, quaisquer danos que o excluído possa eventualmente sofrer em função de mutações no patrimônio da sociedade, verificadas no período compreendido entre a realização da assembléia e o retardado arquivamento da respectiva ata, poderão, em princípio, ser pessoalmente imputados aos administradores responsáveis por tal providência.

Em relação à exclusão judicial, a sentença que determinar a expulsão do sócio possui eficácia constitutiva negativa e não meramente declaratória. Nesse sentido, a respectiva decisão judicial produz efeitos ex nunc. A data precisa da exclusão dependerá, em regra, de 
aspectos concretos do processo de exclusão, tal como a eventual concessão de tutela antecipada ou o reconhecimento de efeito suspensivo a recursos propostos pelas partes.

De fato, existem diversas posições divergentes sobre qual data deve prevalecer como marco temporal para a apuração dos haveres do excluído, nos casos em que a expulsão se processa pela via judicial. Entre as teses adotadas pela doutrina e pela jurisprudência podese citar: (i) a data da citação inicial do excluendo ${ }^{4}$, (ii) a data da sentença que determina a exclusão $^{5}$, (ii) o momento do trânsito em julgado desta última ${ }^{6}$, (iii) a data de indeferimento de agravo de instrumento que visava reverter decisão interlocutória que havia determinado o afastamento do sócio da sociedade ${ }^{7}$ e (iv) a data de averbação, no órgão de registro competente, do ato que reflita a alteração do quadro societário determinada por sentença transitada em julgado ${ }^{8}$.

Tendo em vista a já mencionada necessidade de proteger os interesses de terceiros, parece oportuno, também no âmbito da exclusão judicial, cingir os efeitos da exclusão de modo a estabelecer uma distinção entre o momento em que a expulsão torna-se eficaz entre os sócios e a data de referência para a apuração dos haveres do excluído. De acordo com essa visão, o excluído não pode mais exercer as prerrogativas de sócio a partir do momento em que assim determinar o juízo competente pela exclusão. A data de referência para a

\footnotetext{
4 “...provejo em parte a apelação, para decretar apenas a dissolução parcial da sociedade, dela permitindo a retirada do sócio dissidente e mandando que os seus haveres sejam apurados em balanço que tomará como consideração a data da citação inicial.” TAMG, Rel. Exmo. Juiz Hélio Costa, Apelação Cível n 31.575, 15/06/1970 (RT 426/230).

5 “...é entendimento desta relatoria que o marco inicial para a retirada da autora da sociedade, no que concerne a apuração de haveres, é a data da sentença de primeiro grau, posto que nesta foi determinada a alteração do contrato social da empresa, excluindo-se desta, a sócia...” TJRJ, $18^{\mathrm{a}}$ Câmara Cível, Rel. Exmo. Des. Jorge Luiz Habib, Embargos de Declaração a decisão proferida na Apelação Cível nº 8.808/07, 25/09/2007.

6 "Pleiteada a exclusão por via judicial, o marco [temporal] será forçosamente o do trânsito em julgado, a não ser que, de fato, o sócio sponte propria já tenha abandonado a sociedade.” in P. FONSECA, Dissolução Parcial, Retirada e Exclusão de Sócio, p. 206.

7 "Tem-se, então, as seguintes opções para firmar-se a data para proceder-se a apuração de haveres: 1) a da decisão cautelar, 2) a da publicidade do ato, consubstanciada na averbação da medida na JUCERJA, 3) a da citação do réu apelante, 4) a do trânsito em julgado do agravo de instrumento do apelante, que buscou reverter aquela decisão que o afastou da sociedade. Resolvi optar pela última, ou seja, a do trânsito em julgado do referido agravo. Isto porque considero que ali se exauriu, derradeiramente, qualquer possibilidade de reversão, o que manteve o sócio apelante afastado, pode-se dizer definitivamente, até a sentença que, aliás, lhe foi desfavorável.” TJRJ, Rel. Exmo. Des. Benedicto Abicair, Apelação Cível n 2007.001.00521, 03/04/2007.

8 "Sendo assim, uma vez verificada a exclusão do sócio, seja extrajudicialmente, [...], seja judicialmente, nos termos do artigo 1.030 (com o arquivamento da alteração contratual que reflita a decisão de exclusão transitada em julgado), impõe-se a liquidação da quota do excluído, com o cálculo dos haveres que lhe serão devidos e o respectivo pagamento.” (sem grifo no original) in M. CARVALHOSA, Comentários ao Código Civil - Parte Especial do Direito de Empresa, p. 326.
} 
apuração dos haveres, contudo, deve ser a data de arquivamento junto ao registro competente do ofício judicial ou ato societário que reflita a decisão judicial de exclusão.

Pode-se estabelecer um paralelo, a esse respeito, com o marco inicial adotado pelo legislador para delimitar a responsabilidade residual do excluído pelas obrigações da sociedade - quando e se existir tal responsabilidade, conforme se discute a seguir. Em tal situação, nos termos do artigo 1.032 do Código Civil de 2002, o termo inicial do prazo de dois anos é justamente a data de arquivamento dos atos que refletem ou determinam a exclusão do sócio.

\subsection{Apuração dos Haveres e Destino das Quotas do Excluído}

O presente estudo não compreende uma análise mais detida da questão da apuração dos haveres do sócio excluído. Não se trata de subestimar a importância do tema. Com efeito, sob um ponto de vista pragmático, se a exclusão pode em certas situações representar uma grave "derrota”, moral e jurídica, para o excluído, uma apuração de haveres em termos vantajosos é capaz de convertê-la em uma vitória econômica.

Ocorre que a apuração de haveres representa um tema muito mais amplo do que a exclusão de quotistas em si e diz respeito a todas as hipóteses de resolução da sociedade limitadamente a um sócio, tal como a retirada unilateral voluntária (quando e se admitida), o recesso, a penhora judicial da participação, arrecadação das quotas pelo juízo falimentar e a morte do sócio (quando não admitida a sua substituição por seus herdeiros).

Além disso, ainda que os pressupostos e condições da apuração sejam determinados pelo juiz, à luz das disposições legais e contratuais aplicáveis -, o trabalho de avaliação que se segue possui natureza predominantemente contábil e econômica. Com efeito, uma investigação do tema da apuração de haveres passa necessariamente pelo enfrentamento de questões como a diferença entre "valor” e "preço”, e requer a análise crítica das diversas categorias de métodos de avaliação (principalmente, o fluxo de caixa descontado, a avaliação relativa e a avaliação por direitos contingentes ${ }^{9}$ ).

\footnotetext{
${ }^{9}$ P. SCHMIDT, J. SANTOS, Fundamentos da Avaliação de Empresas, p. 4-5.
} 
De qualquer modo, convém reiterar, ainda que a título de nota, a inadequação de critérios arbitrários ou meramente contábeis para o cálculo dos haveres devidos ao excluído, prática já repudiada a seu tempo pela jurisprudência brasileira ${ }^{10}$. Também merece reparo o entendimento que propugnava pela apuração de haveres aplicando os mesmos critérios previstos para a dissolução total ${ }^{11}$. Apesar de ter nascido como forma de proteger a posição do ex-sócio, credor dos haveres, diante de uma legislação antiquada e inadequada (em particular, o artigo 15 do Decreto 3.708/19), esta última tese também é conceitualmente falha, pois a forma de cálculo do valor dos ativos imateriais de uma sociedade em plena atividade é absolutamente diversa do método aplicado a uma sociedade em fase de dissolução ou em estado de inatividade.

O Código Civil de 2002 não contribui muito para a pacificação deste tema, ao determinar que a apuração dos haveres de excluído deve ser realizada com base no enigmático conceito de "balanço patrimonial”, mencionado pelo artigo 1.031, um dispositivo do capítulo das sociedades simples, mas que se aplica à sociedade limitada - mesmo no caso em que o regime supletivo eleito seja a disciplina das sociedades anônimas - por força da remissão expressa contida no artigo 1.086.

O artigo 1.031 esclarece, ao menos - com a expressão "considerada pelo montante efetivamente realizado" -, que a apuração de haveres se limita exclusivamente à participação no capital social devidamente integralizada pelo quotista excluído, de forma que devem ser desconsideradas, para fins de cálculo do montante devido, suas quotas (ou parte de única quota) subscritas mas não pagas.

É criticável o exíguo prazo de noventa dias, estabelecido pelo parágrafo $2^{\circ}$ do artigo 1.031 , para o pagamento dos haveres do excluendo. É lamentável que, nesta questão, o Código Civil de 2002 tenha se distanciado do modelo italiano. Com efeito, o artigo 2.289 do Código Civil Italiano estabelece um prazo de seis meses para o pagamento dos haveres.

\footnotetext{
${ }^{10}$ Um dos importantes passos em tal sentido foi a aprovação da Súmula n 265 do Supremo Tribunal Federal, segundo a qual: "Na apuração de haveres, não prevalece o balanço não aprovado pelo sócio falecido, excluído ou que se retirou”.

11 "Na sociedade constituída por sócios diversos, retirante um deles, o critério de liquidação dos haveres, segundo a doutrina e a jurisprudência, há de ser, utilizando-se o balanço de determinação, como se tratasse de dissolução total.” STJ, Recurso Especial n 37.702-0 SP, Rel. Exmo. Min. Waldemar Zveiter, D.J.U. 13/12/1993.
} 
Conforme a lição do Professor Haroldo Verçosa, a interpretação mais razoável para o parágrafo $2^{\circ}$ do artigo 1.031 é a de que ele não estabelece um limite temporal máximo para todo o procedimento de apuração dos haveres, mas simplesmente define o prazo para pagamento do saldo (eventualmente) devido ao ex-sócio, a contar do momento em que o valor da participação tenha sido calculado e seja conhecido ${ }^{12}$ - daí a referência a "quota liquidada”.

Merece encômios, de qualquer modo, a opção legislativa de se atribuir um caráter expressamente dispositivo, derrogável por cláusula expressa do contrato social, à segunda metade do caput do artigo 1.031, por meio do uso da expressão "salvo disposição contratual em contrário”. Isso assegura aos sócios a possibilidade de escolher uma forma de apuração de haveres compatível com as atividades da sociedade e com sua estrutura patrimonial. Além disso, o contrato social poderá prever o pagamento dos haveres de forma parcelada, em prazo mais razoável do que o critério legal.

Cumpre entender, contudo, que a faculdade outorgada pelo legislador deve ser exercida pelos sócios dentro de determinados limites ${ }^{13}$. Assim, qualquer que seja o método adotado, não deve se tratar de valor fixo ou arbitrário, mantendo alguma relação mínima com o desempenho econômico efetivo da sociedade. De outro modo, ocorreria quase que inevitavelmente uma situação de enriquecimento ilícito, da sociedade ou do excluído, conforme o caso. Se, no momento da resolução do vínculo da sociedade com o excluído, o real valor econômico da participação deste último estivesse acima do montante arbitrariamente pré-definido, haveria efetiva distribuição de lucros fictícios, se estivesse abaixo, o sócio expulso seria impedido de participar dos ganhos sociais, em violação, respectivamente, aos artigos 1.009 e 1.008 do Código Civil de 2002.

O artigo 1.031 prevê como resultado da liquidação da quota do excluendo a redução do capital social, salvo eventual recomposição de seu valor por meio de aportes adicionais por parte dos sócios remanescentes. A redução do capital em tal hipótese está muito mais

12 “O prazo dado pelo $\S 2^{\circ}$ do art. 1.031 diz respeito ao pagamento efetivo, depois de liquidada a quota. Mas o legislador não estabeleceu qualquer prazo para a fase de liquidação. Este prazo deverá ser razoável, sendo obrigação dos administradores da sociedade diligenciar no sentido de compor no tempo mais breve possível os recursos para o pagamento a ser feito ao sócio reitrante ou excluído, ou aos seus herdeiros. Eventual demora não justificada na liquidação poderá levar a um pedido de indenização por perdas e danos.” in H. VERÇOSA, Curso de Direito Comercial, vol. 2, p. 347.

13 “O contrato social, [...], pode apresentar critérios diversos para a exclusão do sócio, desde que não sejam considerados abusivos.”'(sem grifo no original) in H. VERÇOSA, Curso de Direito Comercial, vol. 2, p. 347. 
próxima ao conceito de absorção de perdas irreparáveis, previsto pelo artigo 1.082, inciso I, do que da diminuição do capital excessivo em relação ao objeto social, mencionada no inciso II, do mesmo artigo. Assim, poderia se argumentar que a operação de redução de capital social subseqüente à exclusão de um sócio não se sujeita à possibilidade de oposição por parte dos credores, como previsto no artigo 1.084.

Todavia, enquanto o inciso I do artigo 1.082 prevê expressamente que a redução para absorção de perdas é condicionada à prévia integralização total do capital social, o artigo 1.031 indica que a apuração de haveres se limita ao valor efetivamente realizado da quota, reconhecendo que a exclusão - e, por conseguinte a redução do capital - pode ocorrer mesmo que exista uma participação subscrita, mas não integralizada. Nesse sentido, parece mais adequado entender que a redução do capital social resultante da expulsão de um sócio representa uma hipótese particular e excepcional de tal operação, que simplesmente não se sujeita ao disposto na Seção VI do capítulo do Código Civil de 2002 dedicado às sociedades limitadas (artigos 1.081 a 1.084).

De qualquer modo, a própria imposição da redução do capital social nos casos em que os sócios remanescentes não queiram ou não possam suprir a quota do sócio excluído é questionável. Trata-se de uma solução inadequada e extremamente restritiva, sobretudo para as sociedades limitadas cujo regime esteja mais próximo da disciplina das sociedades anônimas.

A única possibilidade expressamente prevista pela lei para evitar a redução do capital social por meio da admissão de terceiros no quadro de sócios está contida no artigo 1.058, que trata especificamente da transferência das quotas do sócio remisso.

O artigo 1.031 determina que é sempre necessária a liquidação da quota do sócio cujo vínculo contratual com a sociedade é resolvido, não prevendo a possibilidade de sua transferência para terceiros. Entre as possíveis razões para tal posição legislativa, pode-se cogitar o objetivo de evitar (i) que o afastamento do sócio se caracterizasse como uma “desapropriação privada”, e não como mera resolução contratual, e (ii) que eventuais ônus constituídos pelo ex-sócio sobre a sua quota fossem transmitidos a terceiros. 
De qualquer modo, não há razão convincente para se impedir, relativamente à sociedade limitada, que o suprimento da quota do sócio excluído, quando não realizado pelos sócios remanescentes, seja promovido por terceiros ou pela própria sociedade. Neste aspecto específico, uma aplicação literal e incondicionada das normas da sociedade simples à sociedade limitada seria absolutamente inadequada.

De um lado, a preservação do valor do capital social na sociedade limitada é muito mais importante do que na sociedade simples, dado que na primeira o patrimônio social é, em princípio, a única garantia dos credores, enquanto na segunda os sócios respondem subsidiária, mas ilimitadamente, pelos débitos da sociedade. De outro lado, e em parte pela própria questão do regime de responsabilidade dos quotistas, o ingresso de um estranho no quadro de sócios de uma sociedade limitada representa um evento muito menos traumático do que no âmbito da sociedade simples, típico exemplo de sociedade de pessoas.

Nesse sentido, convém interpretar extensivamente o parágrafo $1^{\circ}$ do artigo 1.031 do Código Civil de 2002, quando aplicado à sociedade limitada, para se admitir que, mediante aprovação dos sócios remanescentes, a recomposição do capital social possa ser realizada por terceiros, que previamente não integravam o quadro de sócios.

Não parece, outrossim, haver justificativa sólida para se impedir a sociedade de promover diretamente a recomposição do capital social, utilizando reservas disponíveis. É perfeitamente possível, e até mesmo comum, que a exclusão seja realizada em regime de urgência, de modo que os sócios remanescentes não tenham tempo hábil para discutir e negociar um imediato aporte adicional de recursos para a recomposição do capital.

Em tais situações, a emissão de novas quotas - em valor igual à participação liquidada do sócio excluído -, a serem temporariamente mantidas “em tesouraria”, representaria um instrumento sobremaneira útil para se conciliar a exclusão do sócio com a preservação do valor do capital social, sem qualquer solução de continuidade. Tais quotas seriam emitidas e integralizadas pela sociedade concomitantemente com a liquidação da participação do excluído e, passado o período tormentoso da deliberação de exclusão, poderia se negociar tranquilamente sua transferência - onerosa - aos sócios remanescentes ou a terceiros. 
Uma vez que o Código Civil de 2002 não repetiu a previsão contida no artigo $8^{\circ}$ do Decreto 3.708/19, poderia se entender que não é mais possível a aquisição pela sociedade, de suas próprias quotas ${ }^{14}$. Esta é a visão defendida pelo Manual de Atos de Registro de Sociedade Limitada, compilado pelo Departamento Nacional de Registro do Comércio DNRC $^{15}$, justamente com base no argumento da inexistência de expressa previsão legal autorizadora de tal operação.

Ocorre que a emissão e manutenção de quotas em tesouraria por do meio do emprego de reservas disponíveis da sociedade não implica em qualquer dano aos credores da sociedade, mas, ao contrário, vincula às atividades e ao patrimônio desta última fundos que, de outra forma, poderiam ser simplesmente distribuídos aos sócios. Tal transação não representa nada mais do que uma forma peculiar de capitalização de reservas.

Ademais, o argumento da ausência de autorização legislativa expressa é especialmente débil nos casos em que a sociedade limitada tenha adotado como disciplina supletiva as normas da sociedade anônima, sujeitando-se, portanto, ao regime estabelecido pela Lei ${ }^{\circ}$ 6.404/76 para as ações em tesouraria.

Enquanto estiverem sob a titularidade da sociedade, os direitos inerentes às quotas em questão, incluída aí a prerrogativa de receber dividendos, são suspensos. De fato, como já há muito estabelecido pela doutrina, a sociedade não se torna sócia de si mesma ${ }^{16}$.

\subsection{Responsabilidade Residual do Sócio Excluído}

Além da questão do destino das quotas do sócio excluído, uma transposição literal e acrítica das normas da sociedade simples para a sociedade limitada também teria conseqüências negativas no que diz respeito à responsabilidade residual do excluído pelas obrigações da sociedade.

\footnotetext{
${ }^{14}$ Alfredo de Assis Gonçalves Neto entende que a aquisição das próprias quotas pela sociedade limitada é possível sob a égide do Código Civil de 2002, mas entende que é necessária cláusula expressa no contrato social. A. GONÇALVES NETO, Lições de Direito Societário, p. 293.

15 “A aquisição de quotas pela própria sociedade já não mais está autorizada pelo novo Código Civil.”, item 3.2.10.1 do Manual de Atos de Registro da Sociedade Limitada, aprovado por meio da Instrução Normativa DNRC n ${ }^{\circ}$ 98/03.

${ }^{16}$ J. GUERREIRO, Aquisição de Quotas pela própria Sociedade, p. 54.
} 
O artigo 1.086 do Código Civil de 2002 faz remissão expressa ao artigo 1.032, atinente às sociedades simples. Este último dispositivo prevê que a exclusão não exime o sócio excluído de sua responsabilidade pelas obrigações sociais anteriores ao seu afastamento, por um prazo de dois anos a contar da averbação do respectivo ato de expulsão. Tal artigo, por via reversa, atribui aos credores sociais o direito de, durante o biênio sucessivo à exclusão, recorrer ao patrimônio do excluído para satisfazer créditos contra a sociedade.

Ocorre que a responsabilidade dos sócios de uma sociedade limitada é, em princípio, limitada ao valor das própria participação, ressalvada a responsabilidade solidária pelo capital social não integralizado e as excepcionais hipóteses de desconsideração da personalidade jurídica.

Dessa forma, é necessário, uma vez mais, ler a remissão normativa expressa à disciplina das sociedades simples no limite de sua compatibilidade com os aspectos estruturais do regime da própria sociedade limitada. Não contendo a lei palavras inúteis, cumpre encontrar um senso lógico para a remissão expressa do artigo 1.086 ao artigo 1.032. A melhor explicação parece ser a de que tal referência, quando aplicada à sociedade limitada, diga respeito unicamente à responsabilidade solidária dos quotistas pelo capital social não integralizado, prevista pelo artigo $1.052^{17}$.

\subsection{Modificação da Firma Social}

Ainda que não seja uma prática comumente adotada na atualidade, é importante recordar que a sociedade limitada pode adotar como nome empresarial, ao invés de uma denominação, uma firma social, composta pelo nome de um ou mais sócios pessoas naturais, como expressamente indicado pelo artigo 1.158 do Código Civil de 2002. Tal procedimento não é obrigatório, como no caso dos tipos societários em que ao menos uma categoria de sócios responde pelas obrigações sociais de forma ilimitada. A inclusão do nome de um sócio na firma social não determina, tampouco, sua responsabilidade pessoal ilimitada, não aplicando-se à sociedade limitada o artigo 1.157.

\footnotetext{
17 “....se o sócio for excluído da sociedade e o capital social desta estiver ainda a descoberto no momento da sua exclusão, o fato de ele ter sido excluído da sociedade não o eximirá dessa responsabilidade solidária, limitada ao montante que faltar à integralização do capital social, pelo período de dois anos após a averbação no registro competente da alteração do contrato social que determinar sua exclusão. Essa responsabilidade somente subsistirá enquanto permanecer a descoberto o capital social durante o período em que o excluído permaneceu como sócio.” in M. CARVALHOSA, Comentários ao Código Civil - Parte Especial do Direito de Empresa, p. 327-328.
} 
O nome empresarial deve ser formado em respeito ao princípio da veracidade, refletindo com precisão, conforme o caso, a atividade principal da sociedade (denominação) ou a composição de seu quadro social (firma). O princípio da veracidade não é expressamente mencionado pelo Código Civil de 2002, mas pode ser inferido de uma interpretação sistemática de tal diploma ${ }^{18}$ e é explicitamente reconhecida por normas reguladoras de caráter infralegal $^{19}$. Além disso, o princípio da veracidade do nome empresarial é, em última análise, uma expressão da boa-fé objetiva em face de terceiros que estabelecem relações da sociedade.

Nos casos em que a firma social seja composta pelos nomes de apenas parte dos sócios, entende-se que ao sufixo "limitada" (ou "Itda.") deve ser anteposta a expressão pluralizadora “e companhia” (ou “e cia.”), de forma a esclarecer a terceiros que a sociedade possui outros quotistas, além daqueles declinados em seu nome empresarial ${ }^{20}$. Trata-se de uma prática não imposta pelo Código Civil de 2002, mas estabelecida expressamente pelo artigo 5, inciso II, alínea “d” da Instrução Normativa DNRC n 104/07.

Nesse sentido, em respeito ao princípio da veracidade, a firma social deve ser modificada para refletir as conseqüências da eventual exclusão de um sócio. Sempre que o nome do excluído fizer parte da firma social, esta deverá ser modificada, suprimindo qualquer referência àquele que deixou de ser sócio, consoante a previsão expressa do artigo 1.165 do Código Civil de 2002.

Por outro lado, no caso em que o nome do excluído não faça parte da firma social, mas sua exclusão crie uma situação em que os nomes de todos os sócios remanescentes estejam incluídos naquela, deverá ser eliminada a expressão pluralizadora “e companhia”. Caso contrário, seria transmitida a errônea idéia de que a sociedade possui outros quotistas além daqueles indicados na denominação social.

\footnotetext{
18 “O princípio da veracidade, embora não seja expresso em nenhum artigo do Código Civil de 2002, sem dúvida alguma norteia a disciplina do nome empresarial nele contida, como se infere da análise de diversos artigos que dispõem sobre a formação da firma social para os diferentes tipos societários e para o empresário individual (arts. 1.156, 1.157 e 1.158).” (grifo no original) in M. CARVALHOSA, Comentários ao Código Civil - Parte Especial do Direito de Empresa, p. 733.

${ }^{19}$ Instrução Normativa DNRC n ${ }^{\circ} 104 / 07$, artigo $5^{\circ}$ caput.

${ }^{20}$ M. CARVALHOSA, Comentários ao Código Civil - Parte Especial do Direito de Empresa, p. 717.
} 
Em tais situações, a alteração da firma social é uma questão diretamente relacionada com a exclusão do sócio. Nesse sentido, a inclusão da questão da modificação da firma social na ordem do dia da assembléia ou reunião destinada a apreciar a exclusão de um sócio não representa uma violação ao requisito de especialidade do conclave, previsto pelo artigo 1.085 do Código Civil de 2002. 


\section{CONSIDERAÇÕES CONCLUSIVAS}

A exclusão de sócios, enquanto tema da análise jurídica, parece se prestar frequentemente à função de marco de fronteira, uma espécie divisor de águas histórico e conceitual. Não que o instituto em questão tenha, por si só, determinado mudanças estruturais nos rumos do Direito Comercial. A questão é que a simples presença da possibilidade de exclusão de sócios tende, amiúde, a sinalizar a transição entre fases históricas importantes e delimitar contornos essenciais entre diferentes noções dogmáticas.

No âmbito do Direito Privado - ao lado de matérias como os efeitos da nulidade do ato constitutivo da sociedade - a questão da exclusão do sócio compeliu a doutrina a reconhecer as diferenças cruciais existentes entre os contratos bilaterais a aqueles pautados pela comunhão de escopo, contribuindo para inspirar a formulação da teoria dos contratos plurilaterais. O que deu ensejo a uma profunda reorganização do Direito das Obrigações.

De fato, a sobrevivência do contrato, após a extromissão de uma das partes contratantes originais assinalava inequivocamente a impossibilidade de se continuar a aplicar acriticamente os cânones clássicos, derivados do Direito romano. Desse modo, em termos históricos, a admissão da exclusão de sócios também serve para ilustrar a afirmação histórica e o amadurecimento do - pragmático e indutivo - Direito dos mercadores, nascido à sombra e à margem da herança romana. A positivação do direito de exclusão, por outro lado, registra a absorção pelos emergentes ordenamentos estatais das normas anteriormente cunhadas no seio de tal sistema corporativo, quando se buscou tornar o Direito Comercial objetivo e de aplicação geral.

Dentro dos mais estreitos limites do Direito Societário, por outro lado, o reconhecimento da existência do direito de exclusão em cada tipo societário - ressalvada a quase onipresente possibilidade de expulsão do sócio remisso - é um dado quase suficiente para, em si, denunciar a natureza de sociedade de pessoas, e não de capitais, de uma determinada forma societária. Com efeito, o instituto da exclusão (sobretudo a exclusão facultativa) tem como pressuposto o exercício de uma influência, pessoal e negativa, do sócio sobre a sociedade. É natural, portanto, que a expulsão seja admitida somente nos casos em que 
exista uma mínima sobreposição de esferas entre sócio e sociedade. Dessa maneira, o instituto da exclusão delineia a separação entre as sociedades de pessoas e as sociedades de capitais e indica o grau de entrelaçamento entre a pessoa do sócio e o ente societário.

No que diz respeito à tradição jurídica brasileira, o tortuoso caminho que, a partir da ampla resistência à admissão da expulsão do sócio, conduziu à consolidação e difusão do instituto, sempre sob a vigência do Código Comercial de 1850 e sem que se verificassem relevantes mudanças no direito positivo, é um testemunho do dinamismo e da atividade criadora da doutrina e da jurisprudência do país. Da posição privilegiada de um observador externo, Tullio Ascarelli já havia notado que os doutrinadores brasileiros, por um longo período órfãos de uma adequada codificação civil e amadurecidos pela experiência de séculos de vigência das Ordenações Filipinas, eram particularmente atentos ao fato de que o Direito não se reduz à lei; esta apenas determina os limites da atividade do intérprete ${ }^{1}$.

A construção do instituto da exclusão de sócios no Brasil é um entre tantos episódios que espelham os reclamos de uma sociedade que deixou de ser agrícola e patriarcal e de uma economia que, nos ombros da industrialização e da urbanização desenfreada, transformouse a passos largos, velozes demais para serem acompanhados por um sistema legislativo inerte. Em tal cenário, coube à doutrina e à jurisprudência arrancar do texto da lei o máximo que nele poderia ser lido, fazendo uma ponte entre as disposições obsoletas e individualistas do Código Comercial de 1850 e a realidade da atividade econômica no país. O revés da moeda de tal estado de coisas foi, como indicado no início do trabalho, uma grande incerteza jurídica, marcada pela falta de uniformidade ínsita a todas as soluções de acomodação.

A atual disciplina do instituto no Brasil, a seu turno, é o reflexo de uma resposta inadequada e tardia, demasiadamente tardia, do legislador para os problemas indicados acima. O novo regime da exclusão de sócios é, nesse contexto, uma ilustração perfeita das principais deficiências do Código Civil de 2002, de recente promulgação, mas orientado por envelhecidas concepções do Direito Societário. O novo procedimento de expulsão é,

\footnotetext{
1 "De um lado, o direito brasileiro apresenta-se dominado por um formalismo geral, pela abundância do que já foi chamado, outras vezes, de caráter lúdico do direito; de outro, o jurista brasileiro, talvez mais do que o europeu, tem sempre presente a diferença entre ‘direito’ e ‘lei’ e, menos que os outros, é inclinado a deixar-se seduzir por mero formalismo positivista, sendo levado, ao contrário, a propor, ante a norma legal, o problema da sua conformidade com o 'direito'.” in T. ASCARELLI, Notas de Direito Comparado Privado ÍtaloBrasileiro, p. 13.
} 
efetivamente, muito mais rígido, complexo, multiforme - subdividindo-se em exclusão de pleno direito, judicial e extrajudicial - e burocratizado do que no sistema anterior.

Isso não significa que as dúvidas enfrentadas na aplicação do instituto tenham sido completamente dissipadas. Ao contrário, em determinadas áreas, foram ampliadas. É paradoxal que o novo diploma tenha introduzido inúmeras restrições e disciplinado de forma pormenorizada diversas matérias, mas, ao mesmo tempo, tenha deixado tantas questões sem resposta, ou então, com respostas demais. Assim, uma vez mais, a lei se distancia da realidade e cabe novamente ao hermeneuta integrar o seu sentido, da melhor forma possível. O objetivo central deste estudo é justamente compilar e documentar os atuais esforços dos doutrinadores brasileiros em tal direção.

É oportuno, desse modo, recapitular as principais conclusões deste trabalho. O primeiro aspecto a ser mencionado é o reconhecimento das diferenças estruturais existentes entre a exclusão de pleno direito, novidade introduzida em nosso ordenamento pelo parágrafo único do artigo 1.030 do Código Civil de 2002, e as hipóteses de exclusão facultativa, previstas pelo caput do artigo 1.030 e pelo artigo 1.085. Como se argumentou, ambas as formas de exclusão se distanciam claramente uma das outras, tanto sob um ponto de vista teleológico, quanto sob a perspectiva dogmática.

Dentre os problemas atinentes ao instituto de exclusão que não podem ser imputados ao Código Civil de 2002, posto que já estavam presentes no período anterior à promulgação da nova lei, o mais relevante, e de mais graves conseqüências, é certamente a tese da ruptura da affectio societatis como causa suficiente para o afastamento de um sócio. Tal entendimento, profundamente enraizado na doutrina e na jurisprudência contemporâneas, continua a aproximar a exclusão, na prática, a uma prerrogativa meramente potestativa. É por tal razão que um tópico do estudo foi especificamente dedicado à crítica de tal posição.

Em termos procedimentais, as principais conclusões da pesquisa dizem respeito à relação entre exclusão judicial e extrajudicial, no âmbito das sociedades limitadas. Conforme se argumentou, a interpretação mais razoável do artigo 1.085 do Código Civil de 2002, e de sua remissão ao artigo 1.030 do mesmo diploma, parece ser a de que, sempre que não for cabível a via extrajudicial, poderá a sociedade recorrer à exclusão processada diante dos 
tribunais. Desse modo, pode-se afirmar que ambos os procedimentos convivem no novo ordenamento.

A esse respeito, cumpre recordar também a defesa do sentido profundo da exclusão extrajudicial, vista não como uma ingênua tentativa de se evitar o conflito judicial, mas como mera forma de adiá-lo, impondo a iniciativa de recorrer aos tribunais ao próprio excluído, em nome da preservação da empresa.

Por fim, sempre em matéria de exclusão judicial, defende-se a natureza estritamente societária do conclave de exclusão, recusando-se paralelos e comparações com qualquer forma de julgamento. Nesse sentido, argumenta-se que a menção a direito de defesa, contida no artigo 1.085 do Código Civil de 2002, representa uma simples referência atécnica ao direito de argumentação do excluendo. 


\section{BIBLIOGRAFIA}

ACQUAS, Brunello, LECIS, Corrado, L'Esclusione del Socio nelle Società di Persone, in CENDON, Paolo (coord.), Il Diritto Privato Oggi, Milano, Giuffrè, 2005, p. 250.

ASCARELLI, Tullio, Corso di Diritto Commerciale - Introduzione e Teoria dell'Impresa, Milano, Dott. A. Giuffrè, 1962, p. 463.

, Problemas das Sociedades Anônimas, 2ª ed., São Paulo, Saraiva, 1969, p.

544.

, O Contrato Plurilateral, in , $2^{\mathrm{a}}$ ed., Problemas das Sociedades

Anônimas e Direito Comparado, São Paulo, Saraiva, 1969.

, Notas de Direito Comparado Privado Ítalo-Brasileiro, in

Estudos e Pareceres, Campinas, Red Livros, 2000, p. 11-40.

ASQUINI, Alberto, I Profili dell'Impresa in Rivista del Diritto Commerciale e del Diritto

Generale delle Obbligazioni, Anno XLI, Parte Prima, Volume 41, Milano, Dottor Francesco Vallardi, 1943, p. 1-20.

ASSIS, Araken de, Resolução do Contrato por Inadimplemento, $4^{\mathrm{a}}$ ed., São Paulo, Revista dos Tribunais, 2004, p. 191.

ASSIS, Olney Queiroz , A Sociedade Contratual e o Sócio Incapaz (Incapacidade Superveniente) no Código Civil de 2002: uma Evidente Inconstitucionalidade, Jus Navigandi, Teresina, ano 8, $\mathrm{n}^{\mathrm{o}}$ 190, 2004, disponível em: http://jus2.uol.com.br/doutrina/texto.asp?id=4640, acesso em: 20/12/2007.

AULETTA, Giuseppe Giacomo, Il Contratto di Società Commerciale - Requisiti, Conclusione, Vizi, Milano, Dott. A. Giuffrè, 1937, p. 328.

AZEVEDO, Álvaro Villaça, Ação de Apuração de Haveres Proposta por Sócio Excluído, in Direito Privado: Casos e Pareceres, São Paulo, IASP/CEJUP, 1986, p. 91-109. 
BARRETO FILHO, Oscar, O Projeto de Código Civil e as Normas sobre a Atividade Negocial, in RDM n ${ }^{\circ}$ 9, 1973, p. 99-102.

BOLlinO, Giuseppe, Le Cause di Esclusione del Socio nelle Società di Persone e nelle Cooperative, in Rivista del Diritto Commerciale e del Diritto Generale delle Obbligazioni, Roma, Dr. Francesco Vallardi, Vol. 90, 1992, Fascicoli 5-6 (Parte I), p. 375-420, Fascicoli 7-8 (Parte II), p. 537-597.

BORBA, José Edwaldo Tavares, Direito Societário, 10ª ed., Rio de Janeiro, Renovar, 2007, p 576.

BORGES, Jose Ferreira, Jurisprudencia do Contracto-Mercantil, e Arestos dos Codigos e Tribunais das Nações mais Cultas da Europa, Lisboa, Sociedade Propagadora de Conhecimentos Úteis, 1844, p. 226.

BRITO, Lauro et ali, Avaliação de Empresas in MARTINS, Eliseu (org.), Avaliação de Empresas: da Mensuração Contábil à Econômica, São Paulo, Atlas, 2001, p. 263 a 308.

BULGARELLI, Waldírio, A Teoria Jurídica de Empresa - Análise Jurídica da Empresarialidade, Tese, USP, DCO, São Paulo, 1984.

BUONOCORE, Vincenzo, CASTELLANO, Gaetano, COSTI, Renzo, Società di Persone, Milano, Dott. A. Giuffrè, 1980, p. 1.496.

BUONOCORE, Vincenzo (coord.), BASSI, Amedeo, PESCATORE, Salvatore, La Riforma del Diritto Societario, Torino, G. Giappichelli, 2003 p. 282.

CAILLAUD, Bernard, L'Exclusion d'un Associé dans les Sociétés, Paris, Sirey, 1966, p. 282.

CAMUZZI, Sergio Scotti, Srl con unico socio non responsabile e impresa individuale a responsabilità limitata nella $12^{a}$ Direttiva CEE, Rivista delle Società, Anno 35\%1990, maggio-giugno 1990, fascicolo $3^{\circ}$, p. 500-506. 
CARVAlHOSA, Modesto, Comentários ao Código Civil - Parte Especial do Direito de Empresa, in AZEVEDO, Antonio Junqueira de (coord.), Comentários ao Código Civil, São Paulo, Saraiva, Vol. 13, 2003, p. 840.

COASE, Ronald Harry, The Firm, the Market and the Law, Chicago, University of Chicago, 1990, p. 217.

COMPARATO, Fábio Konder, Exclusão de Sócio nas Sociedades por Cotas de Responsabilidade Limitada, in RDM n ${ }^{\circ} 25,1997$, p. 39-48.

, Natureza Jurídica do Balanço in Ensaios e Pareceres de Direito Empresarial, Rio de Janeiro, Forense, 1978, p. 29-37.

Exclusão de Sócio, Independentemente de Específica Previsão Legal ou Contratual, in Ensaios e Pareceres de Direito Empresarial, Rio de Janeiro, Forense, 1978, p. 131-149.

, Função Social da Propriedade dos Bens de Produção, in Direito Empresarial: Estudos e Pareceres, São Paulo, Saraiva, 1995, p. 27-37.

CORSI, Francesco, FERRARA JR., Francesco, Gli Imprenditori e le Società, Milano, Dott; A. Giuffrè, $12^{\mathrm{a}}$ ed., 2001, p. 911.

COZIAN, Maurice. VIANDIER, Alain. DEBOISSY, Florence, Manuel - Droit de Sociétés, Paris, Lexis Nexis, 2006, p. 674.

DALMARTELLO, Arturo, L'Esclusione dei Soci dalle Società Commerciali, Padova, Dott. Antonio Milani, 1939, p. 338.

EISENBERG, Melvin Aron, Corporations and Other Business Organizations, concise $8^{\text {th }}$ ed., New York, Foundation Press, 2000, p. 981. 
ESTRELLA, Hernani, Apuração dos Haveres de Sócio, Rio de Janeiro, José Konfino, 1960, p. 305.

FARIA, S. Soares de, Da Exclusão de Socios nas Sociedades de Responsabilidade Illimitada, São Paulo, Saraiva, 1926, p. 68.

FERRARA, Francesco, Le Persone Giuridiche, in VASSALI, Filippo (dir.), Trattato di Diritto Civile Italiano, Torino, Unione Tipografico-Editrice Torinese, 1956, vol. 2, tomo 2, p. 474.

FERREIRA, Waldemar, Instituições de Direito Comercial, $4^{\mathrm{a}}$ ed., São Paulo, Max Limonad, 1954, vol. 1, p. 560.

Tratado de Sociedades Mercantis, $5^{\text {a }}$ ed., Rio de Janeiro, Nacional de Direito, Vol. II, 1958, p. 626.

FERRO-LUZZI, Paolo, I Contratti Associativi, Milano, Dott. A. Giuffrè, 1976, p. 392.

FONSECA, Priscila Maria Pereira Corrêa da, Dissolução Parcial, Retirada e Exclusão de Sócio, $4^{\text {a }}$ ed., São Paulo, Atlas, 2007, p. 264.

FRANCO, Vera Helena de Mello, Dissolução Parcial e Recesso nas Sociedades por Quotas de Responsabilidade Limitada - Legitimidade e Procedimento - Critério e Momento da Apuração de Haveres, in RDM, nº 75, 1989, p. 19-30.

, O Triste Fim das Sociedades Limitadas no Novo Código Civil in RDM n ${ }^{\circ}$ 123, 2001, p. 81-85.

FREITAS, Augusto Teixeira de, Código Civil - Esbôço, Rio de Janeiro, Ministério da Justiça e Negócios Interiores, 1952, vol. 4, p. 633-1089.

GALGANO, Francesco, Le Nuove Società di Capitali e Cooperative, in GALGANO, Francesco, GENGHINI, Ricardo, Il Nuovo Diritto Societario, in GALGANO, Francesco 
(coord.), Trattato di Diritto Commerciale e di Diritto Pubblico dell'Economia, 2a ed. Padova, CEDAM, 2004, vol. 29, Tomo II, p. 570.

, Lex Mercatoria, 4ª ed., Bologna, Il Mulino, 2001, p. 264.

, Diritto Privato, 10ª ed., Padova, CEDAM, 1999, p. 1.018.

GONÇALVES NETO, Alfredo de Assis, Lições de Direito Societário, 2a ed., São Paulo, Juarez de Oliveira, 2004, p. 368.

GUIMARÃES, Leonardo, Exclusão de Sócio em Sociedades Limitadas no Novo Código Civil, in RDM, n 129, 2003, p. 108-120.

GUERREIRO, José Alexandre Tavares, Aquisição de Quotas pela própria Sociedade, in RDM, nº 36, 1979, p. 49-57.

GRUNEWALD, Barbara, Gesellschaftsrecht, 6. Auflage, Tübigen, Mohrs Siebeck, 2005, p. 436.

HUECK, Alfred, Gesellschaftsrecht, München, C. H. Beck’sche, 1975, p. 311.

HOLMSTROM, Bengt, ROBERTS, John, The Boundaries of the Firm Revisited in Journal of Economic Perspectives, vol. 12, $\mathrm{n}^{\mathrm{o}}$ 4, 1998, disponível em: http://links.jstor.org/sici?sici=0895-3309\%28199823\%2912\%3A4\%3C73\%3ATBOTFR \%3E2.0.CO\%3B@-O (JSTOR), acesso em: 23/03/2005, p. 73-94.

INNOCENTI, Osmida, L’Esclusione del Socio, Padova, CEDAM, 1956, p. 195.

IRTI, Natalino, L’Ordine Giuridico del Mercato, Roma, Laterza, 2001, p. 156.

LATORRACA, Sérgio Murilo Zalona, Exclusão de Sócios nas Sociedades por Quotas in Coleção Saraiva de Prática do Direito, São Paulo, Saraiva, Vol. 42, 1989, p. 95. 
LEÃES, Luiz Gastão Paes de Barros, Exclusão Extrajudicial de Sócio em Sociedade por Quotas, in RDM, n 100, 1995, p. 85-97.

A Disciplina do Direito de Empresa no Novo Código Civil Brasileiro, in RDM, n 128, 2002, p. 7-14.

LEITE JÚNIOR, Carlos Antônio Goulart, Affectio Societatis: na Sociedade Civil e na Sociedade Simples, Rio de Janeiro, Forense, 2006, p. 400.

LENZ, Carlos Eduardo Thompson Flores, A Exclusão de Sócio na Sociedade por Cotas de Responsabilidade Limitada, Revista dos Tribunais vol. 638, Ano 77, 1988, p. 64-68.

LO CASCIO, Giovanni, CARESTIA, Antonietta, DI AMATO, Sergio, IANELLO, Giuseppe, MANZO, Gianfranco, PIETRAFORTE, Tiziana, Società a Responsabilità Limitata, in LO CASCIO, Giovanni (coord.), La Riforma del Diritto Societario, Milano, Dott. A. Giuffrè, 2003, Vol. 8, p. 325.

LUCENA, José Waldecy, Das Sociedades Limitadas, 6a ed., Rio de Janeiro, Renovar, 2005, p. 1.142.

MAGLIULO, Federico, Il Recesso e L'Esclusione, in CACCAVALE, Ciro, MAGLIULO, Federico, MALTONI, Marco, TASSINARI, Federico, La Riforma della Società a Responsabilità Limitata, Milano, Wolters Kluwer - IPSOA, 2007, p. 247-310.

MAGLIULO, Federico, TASSINARI, Federico, Evoluzione Storica e Tipo Normativo, in CACCAVALE, Ciro, MAGLIULO, Federico, MALTONI, Marco, TASSINARI, Federico. La Riforma della Società a Responsabilità Limitata, Milano, Wolters Kluwer - IPSOA, 2007, p. 1-22.

MARCONDES, Sylvio, Questões de Direito Mercantil, São Paulo, Saraiva, 1977, p. 300.

MARTINS, Fran, A Exclusão de Sócio nas Sociedades por Quotas, in Direito Societário, Rio de Janeiro, Forense, 1984, p. 245-285. 
MARTINS-COSTA, Judith Hoffmeister, A Boa-Fé no Direito Privado, São Paulo, Revista dos Tribunais, 2000, p. 382.

MAXIMILIANO, Carlos, Hermenêutica e Aplicação do Direito, 19ª ed., Rio de Janeiro, Forense, 2006, p. 342.

MENDONÇA, José Xavier Carvalho de, Tratado de Direito Comercial Brasileiro, $5^{\mathrm{a}}$ ed., Rio de Janeiro, Freitas Bastos, 9 vols., 1955.

MIRANDA, Francisco Cavalcanti Pontes de, Tratado de Direito Privado - Parte Geral, $4^{\mathrm{a}}$ ed., $2^{\mathrm{a}}$ tiragem, São Paulo, Revista dos Tribunais, 1983, Tomo I.

NUNES, A. J. Avelãs, O Direito de Exclusão de Sócios nas Sociedades Comerciais, São Paulo, Cultural Paulista, 2001, p. 296.

PENTEADO, Mauro Rodrigues, Dissolução e Liquidação de Sociedades, 2a ed., São Paulo, Saraiva, 2000, p. 307.

PERRINO, Michele, Le Tecniche di Esclusione del Socio dalla Società, Milano, Dott. A Giuffrè, 1997, p. 392.

POLLOCK, Frederick, On the Law of Partnership, 15 ${ }^{\text {th }}$ ed., London, Stevens, 1952, p. 272.

REALE, Miguel, A Exclusão de Sócio das Sociedades e o Registro do Comércio, in , Nos Quadrantes do Direito Positivo - Estudos e Pareceres, São Paulo, Michalany, 1960, p. 279-308.

A Exclusão de Sócio da Sociedade Civil e o Controle Jurisdicional, in , Nos Quadrantes do Direito Positivo - Estudos e Pareceres, São Paulo, Michalany, 1960, p. 309-318.

Direito de Empresa: Fim de Odiosos Privilégios in Revista Ius Navigandi, $n^{\circ}$ 63, Teresina, 2003, disponível em: http://jus2.uol.com.br/doutrina/texto.asp?id=3819, acesso em: 15/10/2006. 
, A História do Novo Código Civil, in REALE, Miguel, MARTINS-COSTA, Judith, Biblioteca de Direito Civil - Estudos em Homenagem ao Professor Miguel Reale, São Paulo, Revista dos Tribunais, 2005, vol. 1, p. 272.

REQUIÃO, Rubens, A Preservação da Sociedade Comercial pela Exclusão de Sócio, Tese apresentada para concurso à Cátedra de Direito Comercial da Faculdade de Direito da Universidade do Paraná, Curitiba, 1959, p. 276.

RIBEIRO, Renato Ventura, Exclusão de Sócios nas Sociedades Anônimas, Quartier Latin, São Paulo, 2005, p. 352.

SALLES, Marcos Paulo de Almeida, A Visão Jurídica da Empresa na Realidade Brasileira Atual, in RDM, nº 119, 2000, p. 94-108.

SALOMÃO FILHO, Calixto, A Sociedade Unipessoal, São Paulo, Malheiros, 1995, p. 244. , O Novo Direito Societário, $3^{\mathrm{a}}$ ed., São Paulo, Malheiros, 2006, p. 278.

SCHMIDT, Paulo, SANTOS, José Luiz dos, Fundamentos de Avaliação de Empresas, São Paulo, Atlas, 2005, p. 210.

SCHMIDT, Karsten, Gesellschaftsrecht, Köln, Heymann, 1986, p. 1.460.

SZTAJN, Rachel, VERÇOSA, Haroldo Malheiros Duclerc, A Incompletude do Contrato de Sociedade in $\mathrm{RDM}^{\circ}$ 131, 2003, p. 07-20.

TEIXEIRA, Egberto Lacerda, TOZZINI, Syllas (atualiz.), BERGER, Renato (atualiz.), Das Sociedades por Quotas de Responsabilidade Limitada, 2ª ed., São Paulo, Quartier Latin, 2007, p. 448.

VALVERDE, Trajano de Miranda, Sociedades por Ações - Comentários ao Decreto-Lei $n^{o}$ 2.267, de 26 de Setembro de 1940, $3^{\mathrm{a}}$ ed., Rio de Janeiro, Forense, 1959, Vol. II, p. 464. 
VERÇOSA, Haroldo Malheiros Duclerc, Teoria Geral do Direito Comercial e das Atividades Empresariais Mercantis - Introdução à Teoria da Concorrência e dos Bens Imateriais, in Curso de Direito Comercial, São Paulo, Malheiros, Vol. 1, 2004, p. 350.

Teoria Geral das Sociedades Comerciais, in Curso de Direito Comercial, São Paulo, Malheiros, Vol. 2, 2006, p. 560.

VIEIRA, Paulo Albert Weyland, REIS, Ana Paula de Carvalho, As Sociedades Limitadas no Novo Código Civil - A Limitação do Direito de Contratar, in RDM, n 127, 2002, p. 30 51.

VILLAVERDE, Rafael Garcia, La Exclusion de Socios - Causas Legales, Madrid, Montecorvo, 1997, p. 311.

WAMBIER, Luiz Rodrigues, WAMBIER, Teresa Arruda Alvim, MEDINA, José Miguel Garcia, Breves Comentários à Nova Sistemática Processual Civil - 3, São Paulo, Revista dos Tribunais, 2006, p. 382.

WIEDEMAN, Herbert, Gesellschaftsrecht - Rechtsfälle in Frage und Antwort, 5. Auflage, München, C.H. Beck, 1988, p. 554.

WILLIAMSON, Oliver E., Why, Law, Economics and Organization?, Berkeley, 2000, disponível em: http://papers.ssrn.com/sol3/papers.cfm?abstract_id=255624, acesso em: 10/01/2007, p. 37.

WORLD BANK, Doing Business 2008 - Brazil, Banco Mundial, 2007, disponível em: http://www.doingbusiness.org/documents/countryprofiles/BRA.pdf, acesso em: 05/01/2008, p. 83. 


\section{RESUMO}

O objeto principal da dissertação é a análise do regime jurídico da exclusão de sócios nas sociedades limitadas, nos termos do Código Civil de 2002 (Lei Federal n 10.406/02). Parte-se de um exame do percurso histórico de afirmação do instituto, entrelaçado com uma visão panorâmica da disciplina atual da matéria em alguns dos ordenamentos que mais influenciaram o Direito brasileiro, com destaque para Alemanha, França e, sobretudo, Itália. Em relação à experiência brasileira anterior à promulgação do Código Civil de 2002, o estudo concentra-se em demonstrar o caráter eminentemente doutrinário e jurisprudencial da consolidação do instituto. De fato, sempre sob a vigência do Código Comercial de 1850, à margem de quaisquer mudanças legislativas de maior relevo, a possibilidade de exclusão de sócios foi primeiramente recusada, para paulatinamente ser aceita e, finalmente, ser aplicada com exagerada liberalidade. Conceitualmente, a exclusão é enquadrada como uma expressão da especialidade da sociedade, enquanto contrato plurilateral. A exclusão facultativa, em particular - em oposição à exclusão de pleno direito -, é vista como manifestação peculiar da resolução contratual por inadimplemento. O estudo compreende uma análise crítica das disposições do Código Civil de 2002 em matéria societária, além de uma investigação das causas e procedimentos de exclusão sob a vigência de tal diploma. As principais teses defendidas no trabalho são: (i) a diferença estrutural entre a exclusão facultativa, objeto tradicional de estudo da doutrina brasileira, e a exclusão de pleno direito - novidade introduzida no ordenamento brasileiro por inspiração direta da lei italiana -; (ii) deficiência e inadequação da teoria do rompimento da affectio societatis como justa causa para a exclusão; (iii) a duplicidade de procedimentos para a exclusão facultativa, relativamente à sociedade limitada, com o convívio dos procedimentos de exclusão judicial e extrajudicial; (iv) a impossibilidade de se equiparar a assembléia ou reunião de exclusão

a julgamento, recusando-se a atribuição de um verdadeiro “direito de defesa” ao sócio que se deseja excluir. 


\section{ABSTRACT}

The main purpose of the essay is to review the legal discipline of the exclusion of a partner from a limited liability company under the provisions of the Civil Code of 2002 (Federal Law n. 10406/02). The analysis starts with a review of the historical development of the right of exclusion, combined with an overview of the current legal treatment of the issue in a number of jurisdictions that exercised the most relevant influence on Brazilian Law; in particular Germany, France and - above all - Italy. On what regards Brazilian experience prior to the enactment of the Civil Code of 2002, the analysis focuses on illustrating how the development of the right exclusion was mostly based on academic studies and case law. As a matter of fact, under the provisions of the Commercial Code 1850, in spite of the lack of any relevant reforms on statutory legislation, the possibility of exclusion of partner was, at first, rejected and then, gradually accepted. At a later phase, exclusion was even applied without due control. Conceptually, the exclusion of a partner is classified as an expression of the special nature of the company as a plurilateral agreement. In particular, optional exclusion - unlike mandatory exclusion - is seen as a special form of contract termination due to material breach. The research comprehends a critical review of the provisions of the Civil Code of 2002 on corporate law, in addition to an analysis of relevant causes and procedures for the exclusion of a partner under said law. The main theses defended are the following: (i) existence of structural differences between optional exclusion - traditional object of study by Brazilian academics - and mandatory exclusion a new procedure introduced as a result of the direct Italian influence on Brazilian law -, (ii) problems and inadequacy of the theory of rupture of affectio societatis as a cause for exclusion, (iii) existence of two parallel procedures for the optional exclusion of a partner within limited liability companies, one being through a court ruling and the other trough corporate a mere resolution; (iv) impossibility of treating the exclusion through corporate resolution as a form of judgment and, thus, the refusal of recognition of a "right of defense” in favor of the partner that is to be excluded. 


\section{RIASSUNTO}

Lo scopo principale dello scritto è di analizzare il regime giuridico dell'esclusione del socio nella Società limitate nei termini del Codice Civile del 2002 (Legge Federale ${ }^{\circ}$ 10.406/02). L'analisi inizia con un exursus storico che esamina l'affermazione dell'istituto per poi evolversi in una visione panoramica dell'attuale disciplina negli ordinamenti stranieri che hanno maggiormente influenzato il Diritto brasiliano, in particolare Germania, Francia e soprattutto Italia. La presente ricerca, per quanto riguarda l'esperienza brasiliana prima della promulgazione del Codice Civile del 2002, si concentra nel dimostrare il carattere prevalentemente dottrinale e giurisprudenziale della consolidazione dell'istituto dell'esclusione. Di fatto, sotto la vigenza del Codice Commerciale del 1850, a margine di qualsiasi modificazione legislativa di maggior rilievo, la possibilità dell'esclusione del socio è stata, in un primo tempo, respinta, poi gradatamente accettata e in fine applicata con esagerata libertà. Concettualmente l'esclusione è intesa nell'accezione di espressione della speciale natura della società, in quanto (per il suo essere) contratto plurilaterale. In particolare l'esclusione facoltativa - in opposizione all'esclusione di pieno diritto - è vista come manifestazione specifica della risoluzione contrattuale per inadempimento. Lo studio comprende inoltre una analisi critica delle disposizioni del Codice Civile del 2002 in materia societaria, oltre a un esame delle cause e delle procedure per l'esclusione di un socio così come prevede il vigente Codice. Le principali tesi difese in questo scritto sono: (i) la differenza strutturale tra l'esclusione facoltativa, oggetto tradizionale di studio per la Dottrina brasiliana, e l'esclusione di pieno diritto, un caso nuovo introdotto nell’ordinamento brasiliano per diretta ispirazione della Legge italiana; (ii) la deficienza e l'inadeguatezza della teoria della rottura dell' affectio societatis come giusta causa per l'esclusione; (iii) la coesistenza di due differenti e paralleli procedimenti per l'esclusione facoltativa, in riferimento alla società limitata, cioè il procedimento di esclusione giudiziale e quello di esclusione extra-giudiziale; (iv) l'impossibilità di equiparare l'assemblea o riunione di esclusione al giudizio, rifiutando l'attribuzione di un reale “diritto di difesa” al socio che la società desidera escludere. 